Historic, Archive Document

Do not assume content reflects current scientific knowledge, policies, or practices. 



\section{ASTA OHN}

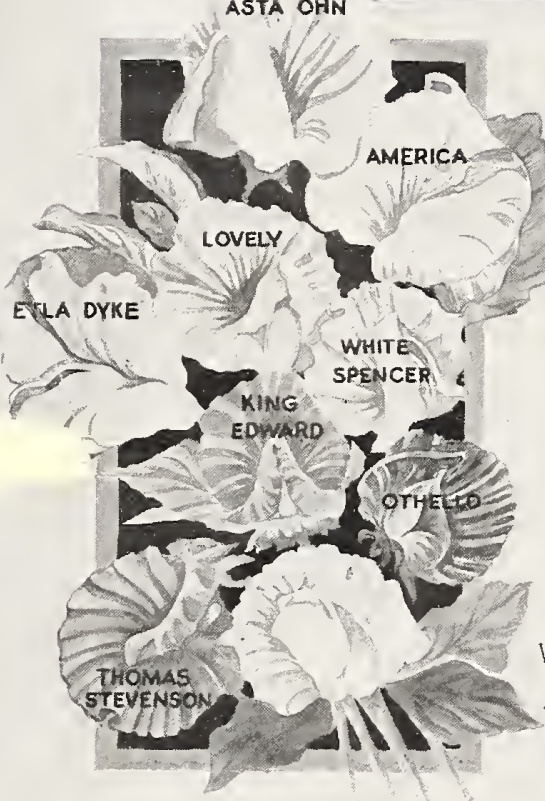

These Flowers are especially adapted to the South.

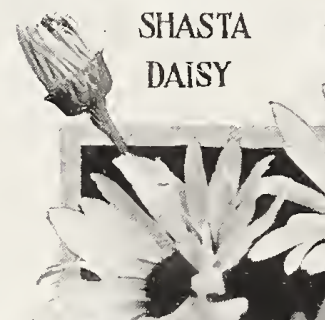

VELUET FH.OWER
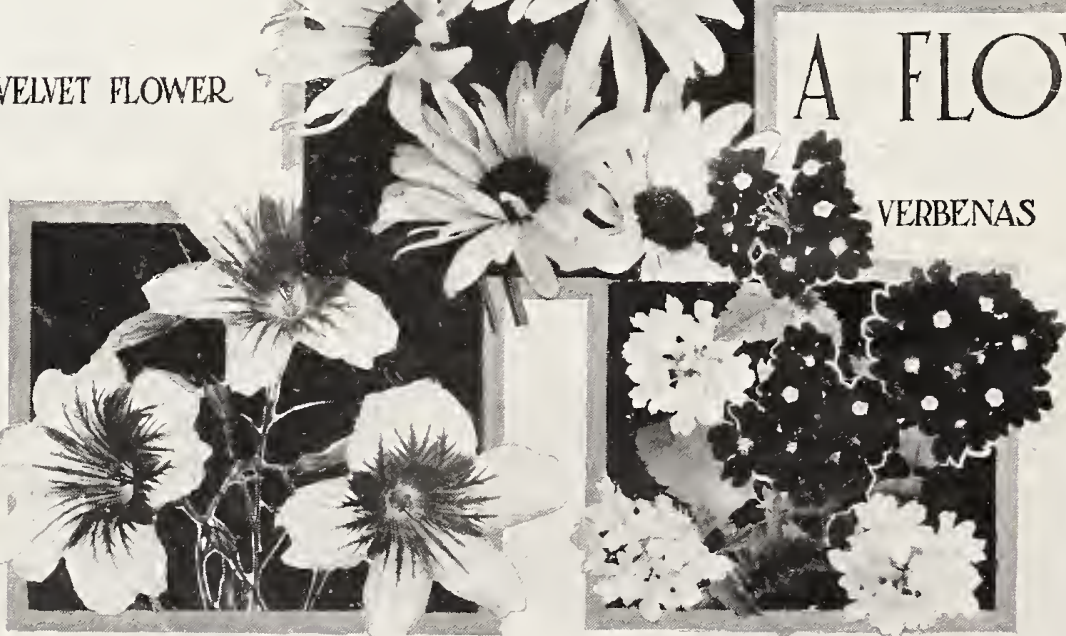

of the Named Varieties of the highest type. One 10ф Packet of each Variety of Sweet Peas illustrated on this page 664
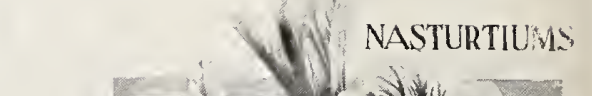

NOTE

WE CANNOT MAKE ANY CHANGES IN THIS COLLECTION

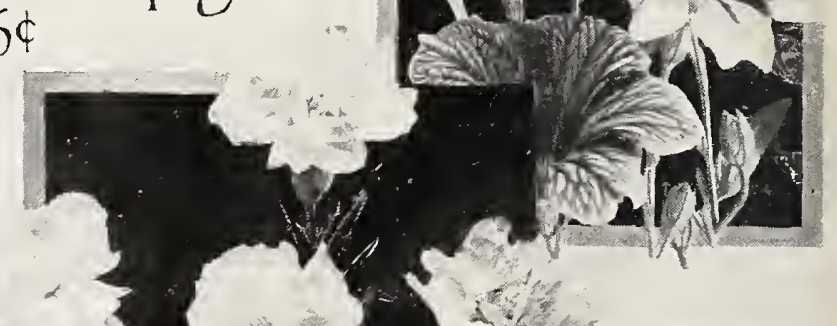

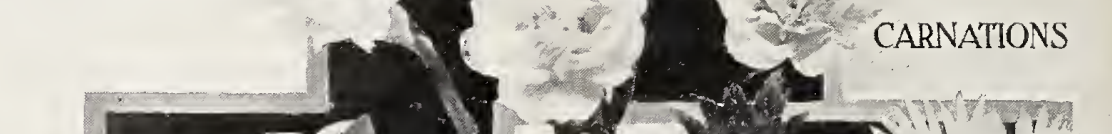
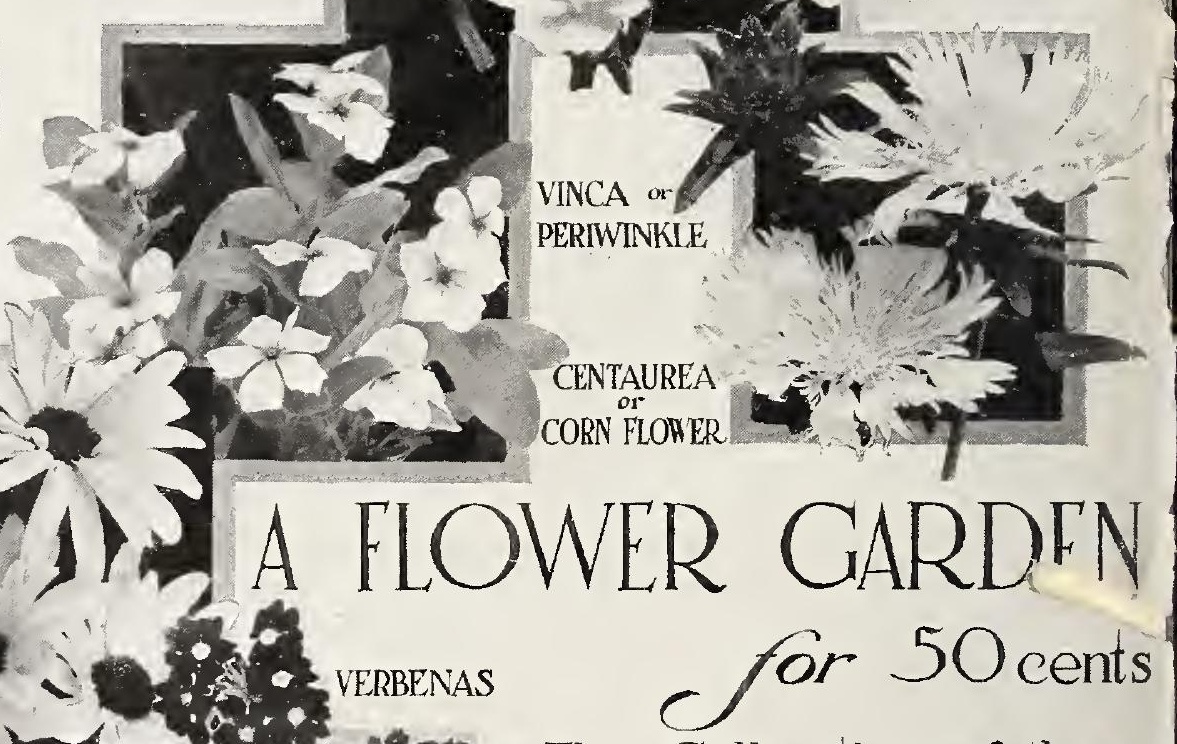

The Collection of the seven popular varieties illustrated, regular price. 75 cents, will be sent Postpaid to any address for 50 cents 
M A K E CROSS H E R E
PLEASE DO NOT WRITE HERE

\section{Amount Enclosed}

(Only if different irom Postoffice)

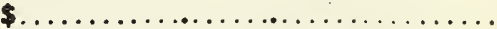
State whether Cash. Draft, P. O. Order, Exp. Money Order or Stamps. If stamps send 3e EXTRA \\ PLEASE READ DIRECTIONS ON PAGE 1 BEFORE ORDERING}

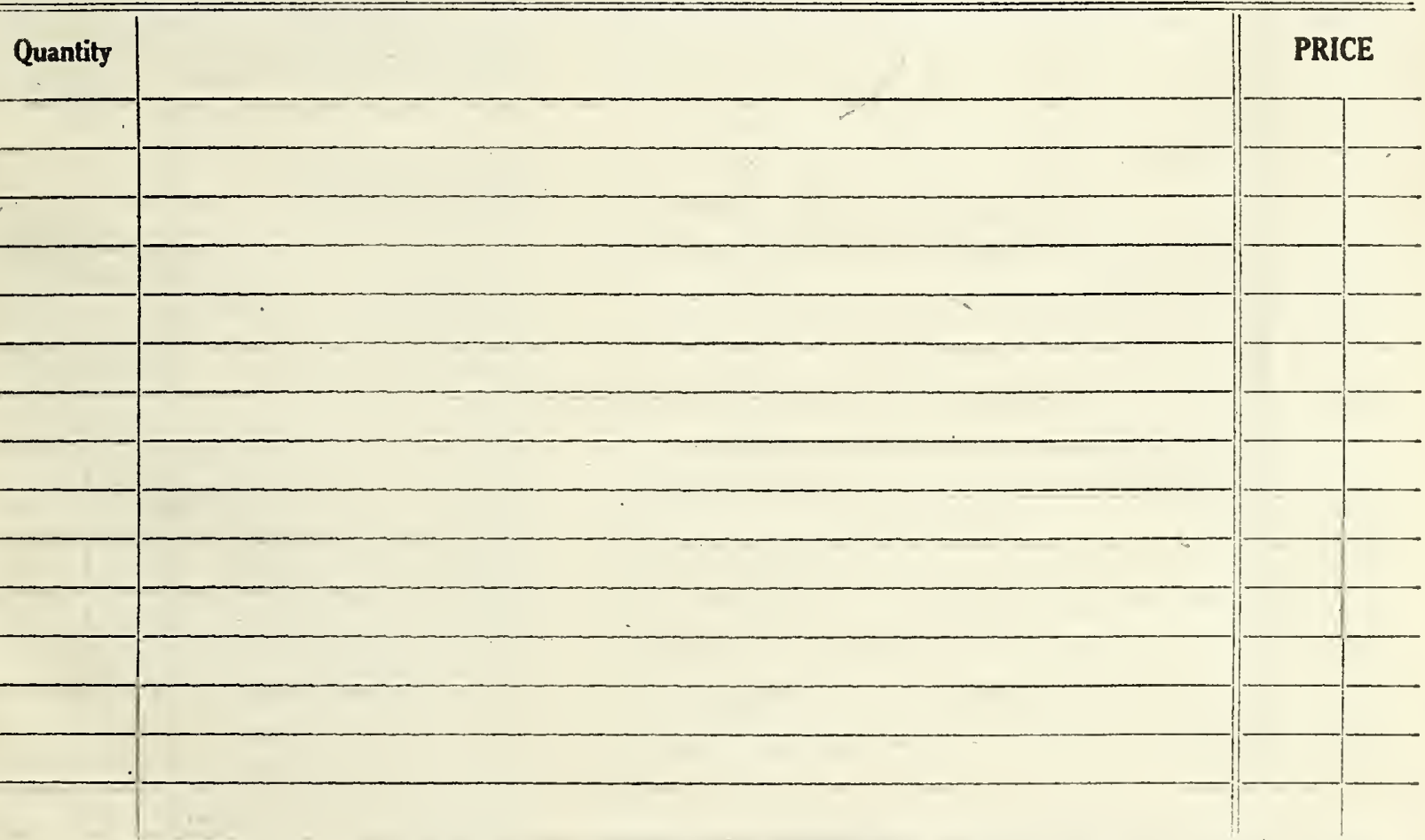



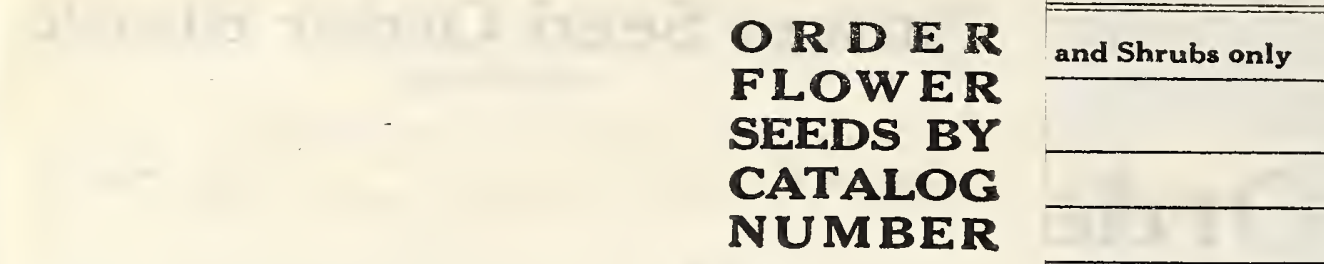

Your Order Blank for Flower Seeds Only TEXAS SEED \& PLANT CO.

DALLAS, TEXAS

IN MOST CASES FLOWER SEEDS WILL BE SENT WITH PLANTS Sometimes it is necessary to send them under separate cover

Name

P.O.

R.F.D.

Box

Stato

If you wish us to substitute similar varieties in case those ordered should be exhausted write "YES"

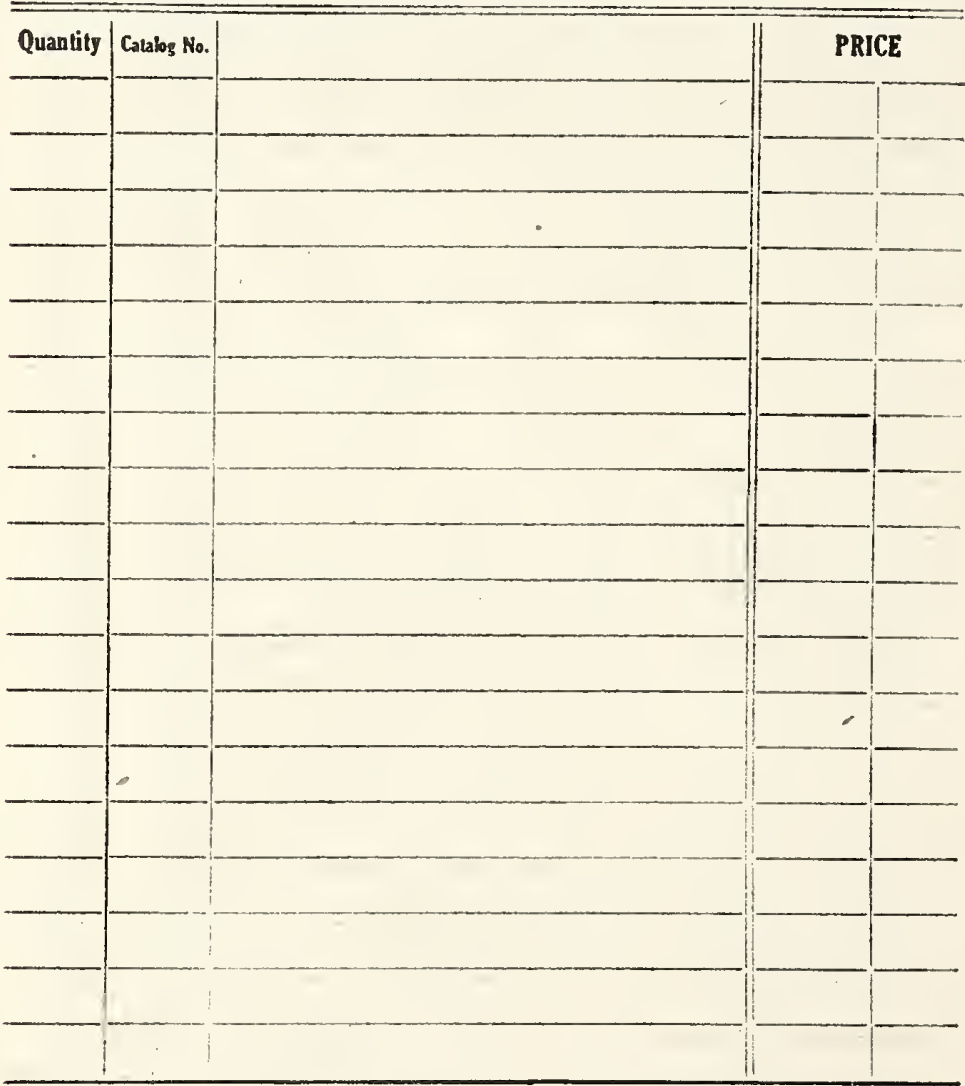

TEXAS SEED \& PLANT CO., Dallas, Texas Special Offer on Page 1

Total

PRICE 


\section{Big 1921 Friendship Offer}

\section{We Actually Share Profits With YOU}

We have selected this PROFIT SHARING idea in order that those who are not well acquainted with our goods may know them better in 1921.

For every $\$ 1.00$ worth of goods bought at single plant, bulb or packet prices, look carefully through our catalogue and select $10 \mathrm{c}$ worth extra for your SHARE OF THE PROFITS. On $\$ 2.00$ worth select $20 \mathrm{c}$ worth for your SHARE OF THE PROFITS. On $\$ 3.00$ worth select $30 \mathrm{c}$ worth extra for your SHARE OF THE PROFITS. Larger orders, PREMIUMS in proportion. Premiums cannot be allowed on Special Offers, Collections, or goods bought at dezen or hundred rate.

Some of your friends vrould be glad to join you in sending an order and thus enable you to get yuur plants FREE. These combined orders must be sent to one address.

Remember that the goods nust be selected and sent with your order. We cannot send them separately.

YOU MUST REALIZE the enormity of such an offer. Last year on a similar liberal profit sharing plan we gave away more than 30,000 (thirty thousand) plants and thousands of packets of flower seeds. These plants and seeds were shipped with the order prepaid absolutely FREE to the customer. Don't fail to get your share of the profits this year.

\section{This Catalog is Our Only Salesman}

Each year we receive a few complaints from people who have bought goods from salesmen who represent themselves as our agents. We wish to make it very plain to our friends that we have no agents.

We are sending this catalog to you as our only agent and ask that you make your selection herein and order directly from us. Using this plan there can be no difference in prices to customers and having no agents' commission to pay linked together with our PROFIT SHARING PLAN enables you to obtain the best plants, flower seeds, cut flowers and nursery stock at the lowest possible cost. Send us your order today.

\section{PLEASE READ THIS BEFORE ORDERING}

We wish to call your attention to the suggestions below which, if followed, will aid greatly in the prompt and satisfactory execution of your orders.

OUR PRICES. Do not compare our prices with those who do not PREPAY charges. Prices quoted in this catalogue are net with all parcel post, express and freight charges prepaid.

INSURED PARCEL POST. If you desire your order to be shipped by insured parcel post, send $12 \mathrm{c}$ extra, otherwise it will not be insured. If you send $12 \mathrm{c}$ extra, state on your order to send by insured parcel post. Special instructions as to how order should be marked an be found in right-hand corner of order blank. Insured parcels are handled with more care than those ient otherwise.

REMITTANCE WITH ORDER. Please send suffisient money to cover your entire order. The safest way is by ileans of nost office money order. If money order gets lost a duplicate can be obtained very easily and there is no danger of their being stolen, as no one an obtain money on them except person or firm to whom they are addressed. We enclose in our catalog for your convenience money order blank which makes it easy to obtain this form of remittance. Cost for obtaining money order is listed on back of blank.

We assume the risk of paper and silver money only when carefully sealed in our self-addressed envelopes and sent by registered mail, otherwise it is at the risk of the sender.

POSTAGE STAMPS. These can be sent when other forms of remittance cannot be had, provided $3 \mathrm{c}$ in stamps extra are sent with every remittance. None but stamps in perfect condition accepted. We much prefer other forms of remittance.

SHIPMENTS. As we prepay all shipments, we withhold the right to ship either parcel post or expressour option.

OUR NURSERY DEPARTMENT is separate from our greenhouse. It is necessary, therefore, that all orders for Fruit Trees, etc., be shipped direct from nursery department. They are not sent with other goods. 


\section{A Real Investment}

There is nothing so decorative and adds so much to the attractiveness of a home as flowers. Ten per cent is added to the value of a place when some thought has been given to the arrangement of shrubbery and flowers. The humblest abode takes on an inviting appearance when vines cover unsightly fences and bright flowers border the way to the door.

A certain per cent of the money we earn should be invested in pleasure, but we want to get the most for our money out of this "pleasure investment." While the growing of food and feed is essential, yet the pleasure that one gets from a flower garden must not be overlooked. No matter who you are or where, you can have flowers. You will be well repaid for the small amount of time needed to tend the flowers.

Our flower seeds have no superiors. Our business experience has shown us that the best advertisement is a satisfied customer, and our high grade strains of seeds are bound to make every one who plants them satisfied. Those who buy from us find that the quantity of our seed and the size and brilliancy of the bloom surpass anything they have ever had. We spare no trouble or expense to get the very best for our customers-the best varieties of all flowers adapted to planting in the south.

Many people prefer to order plants, which saves the trouble of planting seed. We grow all kinds of plants in our greenhouses. Many varieties are very hard to get from seed and we can furnish fine specimens in our plant department. We have ample room in our greenhouses to grow hot house plants and in our fields for shrubbery and hardy plants. We only list varieties of shrubbery, fruit trees, plants, etc., well adapted to our southern climate.

In case you meet with difficulty in cultivation of any particular varieties, write us for free information. We are glad to give helpful ideas straight from our experienced growers.

Decide today to make the investment which will bring you such valuable returns. Plant a flower garden. Let our catalogue be your guide.

How to Grow Flowers. For several years we have printed in our catalog brief instructions for planting and growing flowers that were written for us by one of our customers that is unusually successful in raising flowers. As we do not believe these instructions can be improved, we are printing them again this year. We feel certain you will have flne believe these instructions can be improved, we are printin
success with your flowers if you follow these suggestions.

"Nine-tenths of the failures in raising flowers are caused by improper treatment of the seeds and young plants. The finer seeds should be started in shallow, well-drained boxes in the house and the young seedlings should be transplanted a few times until they are large enough to be set out in the open ground. Do not plant any seed as long as the ground is wet. A mellow loam, enriched with compost of rotted manure and leaf mold, is best adapted to most flowers. Rake the surface as smooth and fine as possible, elevating the surface of the beds and borders slightly in the middle so that surplus water may run off. Cover the different seeds in proportion to their size, giving very thin covering to small seeds and planting large seeds deeper. After planting, press the earth dowil firmly over the seed, else there is danger of them drying out. After the seedlings are up they must have plenty of moisture, but not too much, or they will 'damp off.' During dry weather, or after transplanting, they must be watered frequently."

\section{Annuals}

Varieties that die down the same season and must be replanted each season.

Chinese Woolflower (Celosia) We are featuring this variety, as it is the most magnificent garden flower from July till early frost. Has massive bunches of truly valuable and glorious flower. Easy to grow, and blooms feet high, the blooms starting early with a central globular head, which often reaches the immense size of two feet in circumference. Scores of branches are thrown out, each bearing a ball of scarlet wool. None of the blooms fade in any way until hit by frost. Flowers when cut in a fresh state and carefully dried retain their shape and brilliant color and are useful for winter decorating, like everlastings. (2No. 100.) Seed, per pit. 15c.

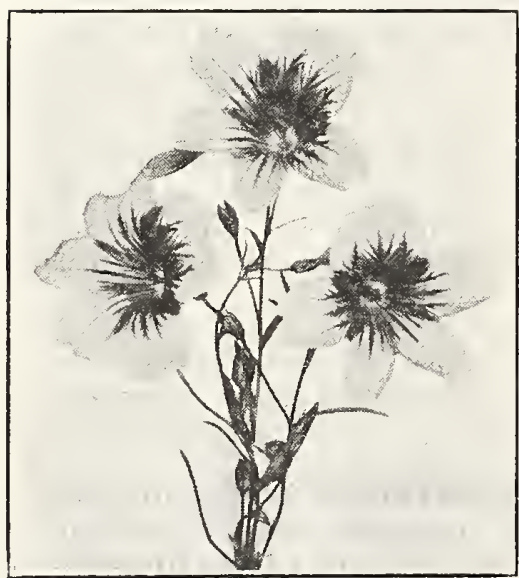

Velvet Flower

\section{Velvet Flower (Salpiglossis)}

A new giant flowering race of this beautiful and popular garden annual. The immense, Petunia-like flowers are borne on dwarf, sturdy branching plants, not exceeding 24 inches in height, that do not require staking. The colors, scarlet, white, rose, violet, etc., are intricately netted, penciled and veined with goldenyellow or other colors. They are of easiest culture and flower profusely during the summer. The long-stemmed flowers are fine for cut-flower decorations.

Scarlet and gold (No. 101) Pkt. $10 \mathrm{c}$. White and gold (No. 102) Pkt. $10 \mathrm{c}$. Rose and gold (No. 103) Fkt. $10 c$. Bright crimson (No. 104) Fkt. $10 \mathrm{c}$. Violet and gold (No. 105) Fkt. 10 c. Yellow (No. 106) Pkt. 10c.

Dark scarlet (No. 107) Pkt. $10 \mathrm{c}$. Mixed colors (No. 108) Prt. $10 \mathrm{c}$.

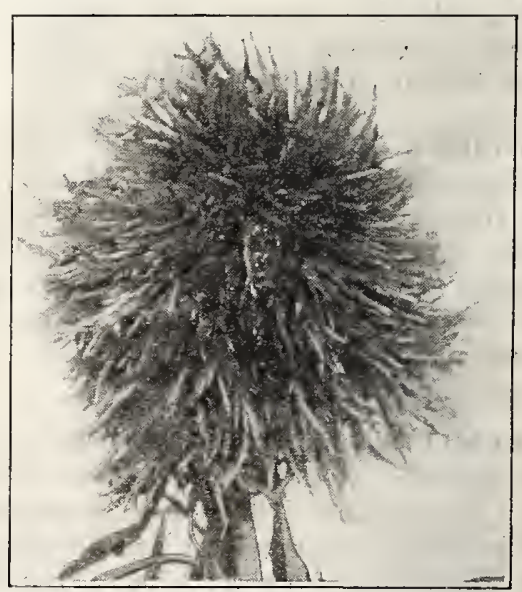

Chinege Woolfower 


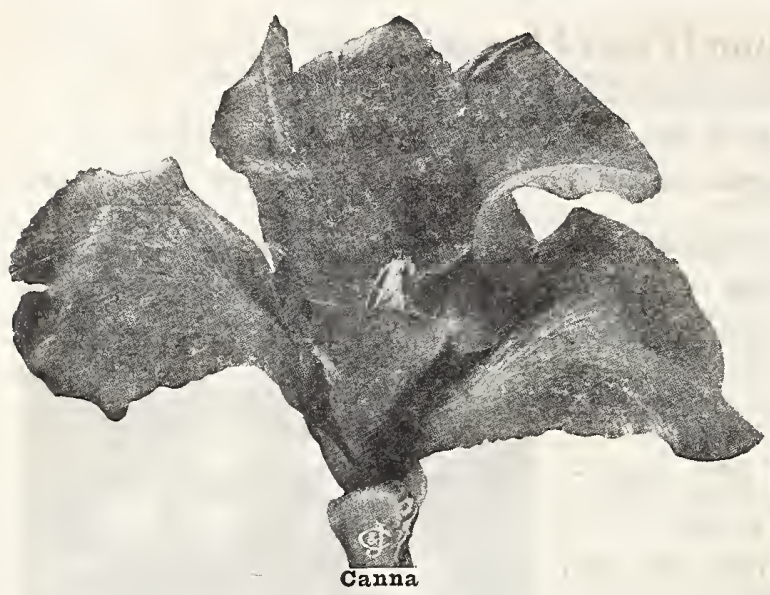

\section{Giant Cannas}

Highly ornamental plants, with broad, massive foliage and tall flower stalks, carrying racemes of crimson, pink, yellow, orange and scarlet blossoms. Soak the seed before planting.

CROZY'S IARGE-FIOWERING, FINEST MIXED (INo. 124) - All newest and most beautiful varieties. Plst. $10 \mathrm{c} ; 0 \mathrm{z} ., 50 \mathrm{c}$.

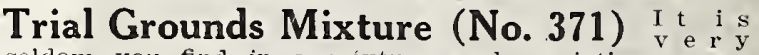
seldom you find in a mixture such varieties as are included in this one. We could sell this mixture of canna seed to florists at a much higher price than we are asking our customers. Pkt. 25c.

Carnation Highly esteemed favorite. Flowers of deCqually well adcious fraglance and rich colors. They ale pots in the house.

CHABAUD'S FINEST FRENCH (No. 139)-These remarkable creations of a French carnationist surpass all others in lichness and variety of colos
bloom in 5 montlis from sowing. Plet. 27c.

MARGUERITE (No. 140)-The flowers of this strain sometimes measule 3 inches across and are doublé as double can be. The colors are extremely varied and beautiful. Plst., 15c.

GIANT MIXED (No. 141) - Saved from extra fine double named flower's. Pkt., $27 \mathrm{c}$.
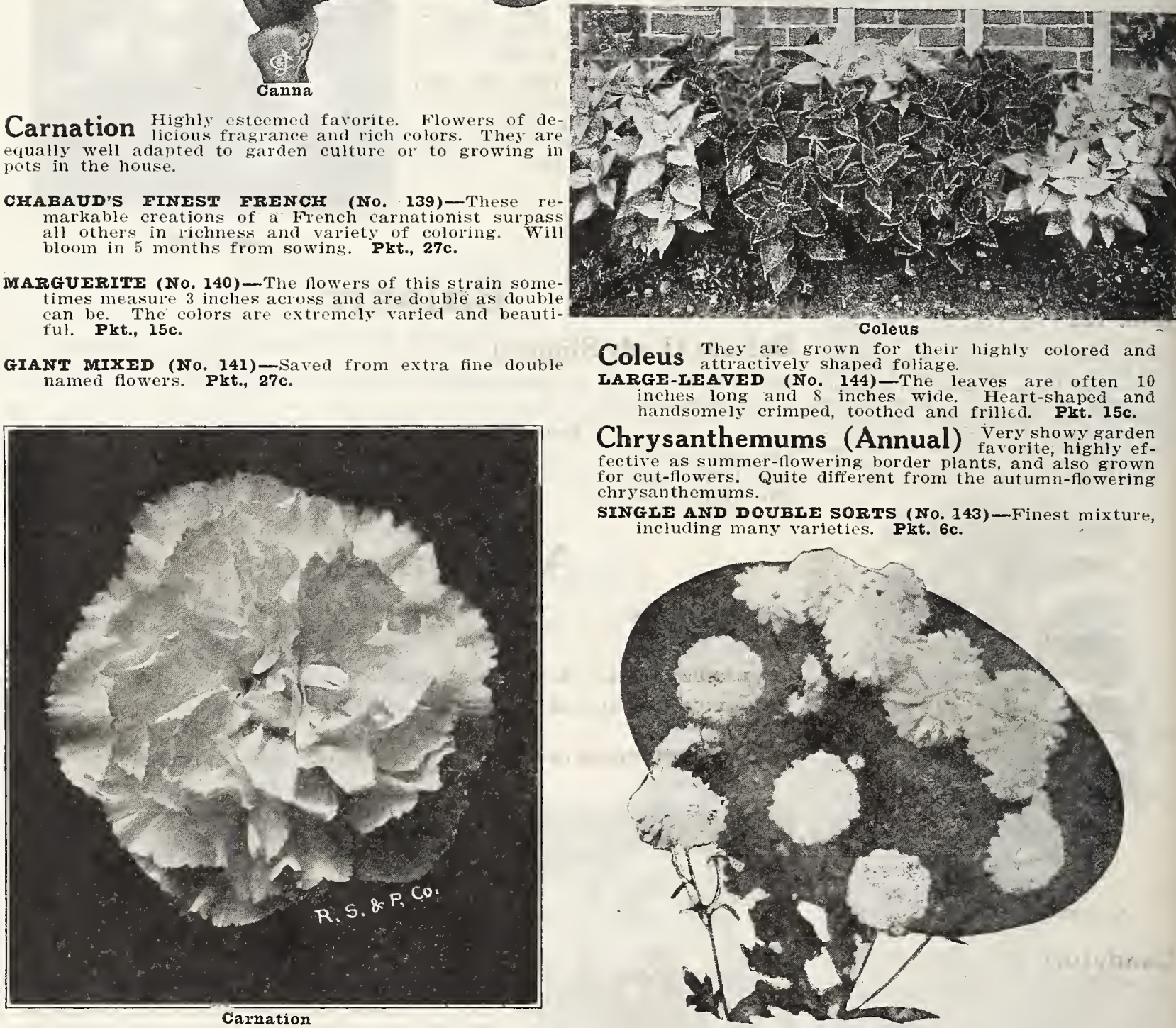

Coleus They are grown for their highly colored and LARGE-LEAVED (No. 144)-Thiag.

inches long and $\delta$ inches wide Heart-shaped and handsomely crimped, toothed and frilled. Plt. 15c.

Chrysanthemums (Annual) $\begin{aligned} & \text { Very showy garden } \\ & \text { favorite, highly ef- }\end{aligned}$ fective as summer-flowering border plants, and also grown for cut-flowers. Quite different from the autumn-flowering chrysanthemums.

SINGIE AND DOUBLE SORTS (No. 143)-Finest mixture, including many varieties. Pkt. 6c.

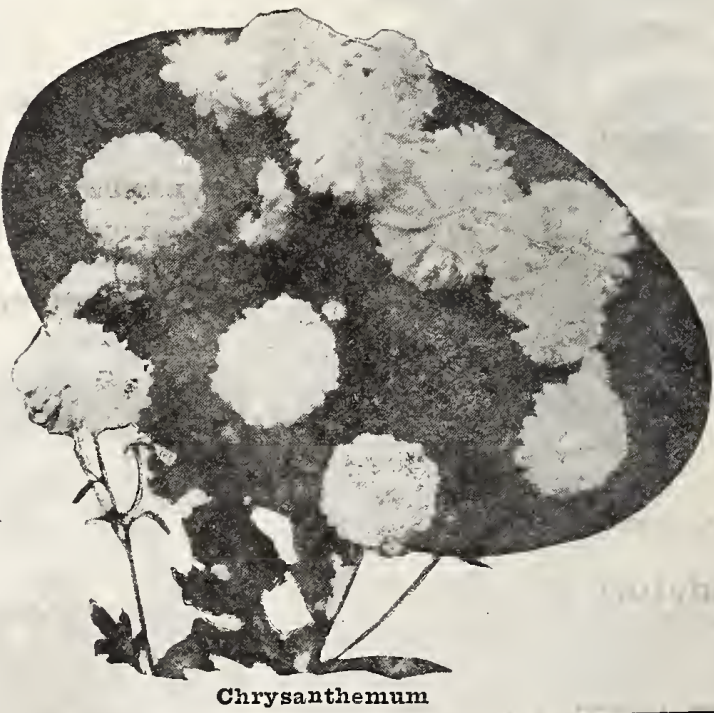

\section{Old Fashioned Flower Garden Collection}

(The kind mother used to grow.) 10 Full Sized Packets for $50 \mathrm{c}$ postpaid. Haven't you often wished for an old-fashioned flower garden like the one at the old home? Here is an opportunity to fulfill your heart's desire. Ten full sized packets of the flowers mother used to grow-zinnias, Canterbury bells, corn flower, sweet alyssum, ageratum, larkspur, balsam, columbine, snapdragons and hollyhocks. All for 50c. 
Centaurea Imperialis $\begin{gathered}\text { This } \\ \text { class }\end{gathered}$ is splendid for cut flower purposes. The beautiful sweet-scented, artistic-shaped flowers are borne on long, strong stems, and when cut will stand for several days in good condition. It is best, in this latitude, to sow very early in the spring, so that they may perfect their flowers before very hot weather comes. We offer the following colors:

(No. 131)-Blue. Pkt. ...........6c (No. 132)-White. Pkt. . .......6 6c (No. 133)-Mixture of the a b ove and many other colors. Pkt...10c

\section{Old Fashioned} Flower Garden For $50 \mathrm{c}$ See Page 4

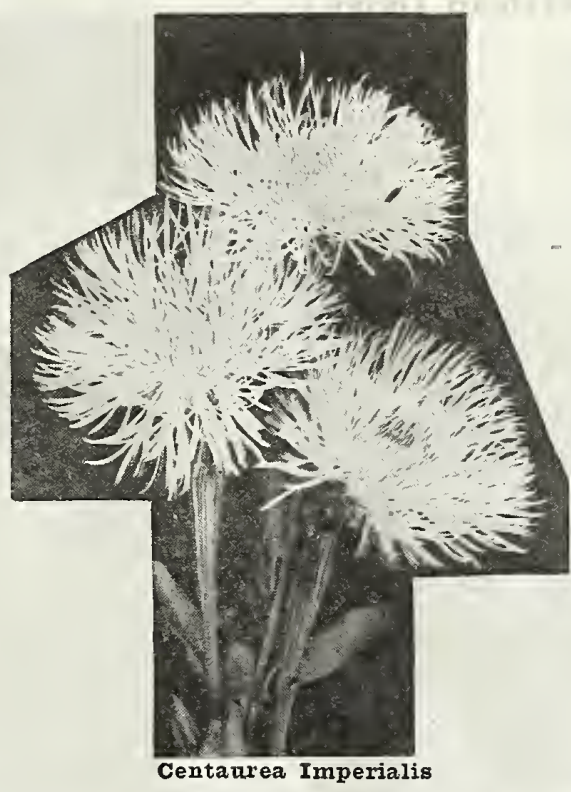

Centaurea-"Cornflower" The Blue Bottle or Bachelor's Button, is one of the most attractive of all hardy annuals, due to the graceful beauty of its old-fashioned flowers. (No. 142)-Mixed pkt.6c.

CENTAUREA SUAVEOLENS (NO. 134)-The plant grows about feet high, producing large flowers on long stems, of a sulphuryellow color and sweet scented The flowers keep a long time when cut, if taken when the
buds are beginning to open. Plst. $6 c$.

GYMNOCARPA (No, 135) (Dusty Miller) - One foot. Foliage finely cut, of silvery gray color, used for bedding. Pirt. 10c.

\section{Celosia, or Cockscomb}

Free flowering, graceful plants Some grow 2 to 4 feet tall, while others remain quite dwarf, and produce massive, heavy flower-heads In every case the flowers are of brilliant shining hues. The dwarf types make excellent pot-plants, while the tall sorts furnish material for bouquets. Half-hardy annual.

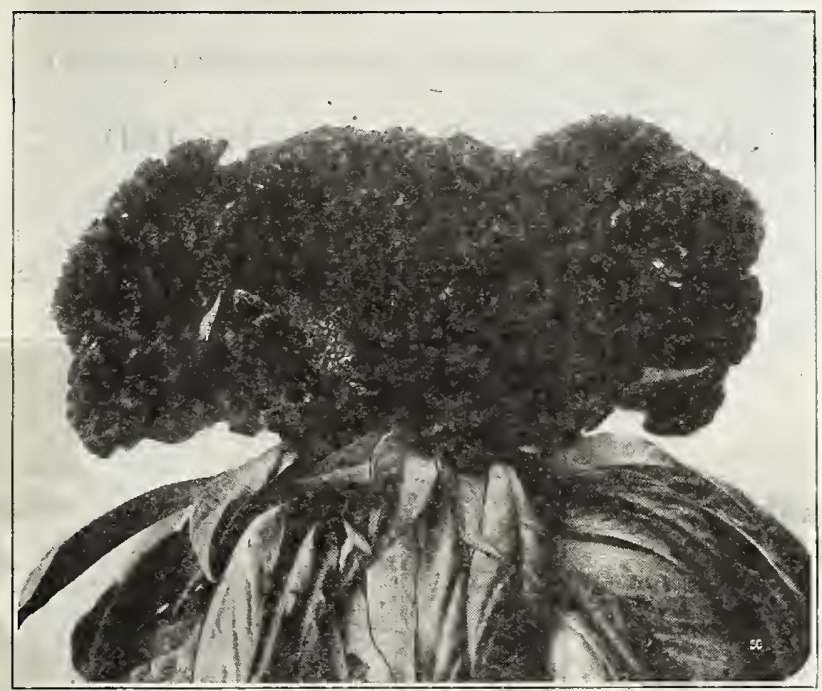

EMPRESS (No. 146)-Rich, velvety crimson combs of large size. Plt. 10c, 1/8 oz., 60c.

DWARE MIXED (No. 147)-Combs of all colors Pkt., 6c, oz. $\$ 1.50$.

FEATHERED MIXED (No. 148)-A very showy annual, growing easily and quickly from seed. It grows to a height of from 3 to $t$ feet and bearing large, conical, plumed heads of either golden yellow, brilliant scarlet, dark red, etc. Pkt. 6c, oz. 50c.

THOMPSON'S MAGNIFICA RED (No. 149)-Of pyramidal growth, attaining a height of 3 feet, and producing graceful, feathery plumes of the most brilliant crimson. In sunlight the rich color of the flower spikes is beautifully contrasted with the bronze-colored follage. Prt. 10c, $1 / 4$ oz. 30c.

THONTSON'S MAGNIFICA YEILOW (No. 150)-Similal to the preceding, except in color. Pkt. 10c, $1 / 4 \mathrm{oz}$. 30c.

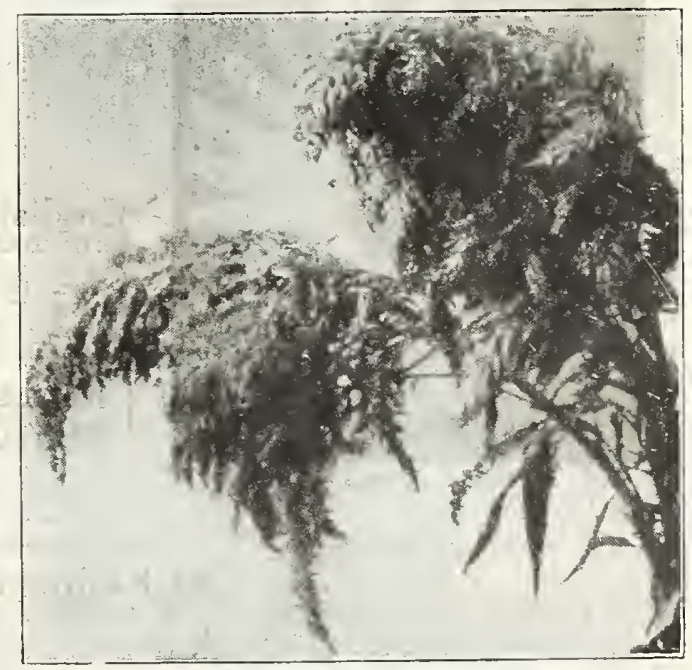

Celosia, Feathered Mixed (No. 137) - In t e n s 10c.

Trisor -Lemon yellow. Plrt. $10 \mathrm{c}$.

Mixed Giant Flowered Calendulas (No. 372)

special prepared mixsorts Pkt. 15 c. 


\section{Dimorphotheca (Golden African Daisy)}

New Hybrid (No. 151) The hardy plants, of neat only twelve to fifteen inches fuse in flowering. Its blossoms measure two and one-half to two and three-quarter inches in diameter. Its strikingly brilliant coloring is rendered even more conspicuous by the dark colored disk surrounded by different colored zones. This splendid annual is well adapted for borders. Pkt. 10c.

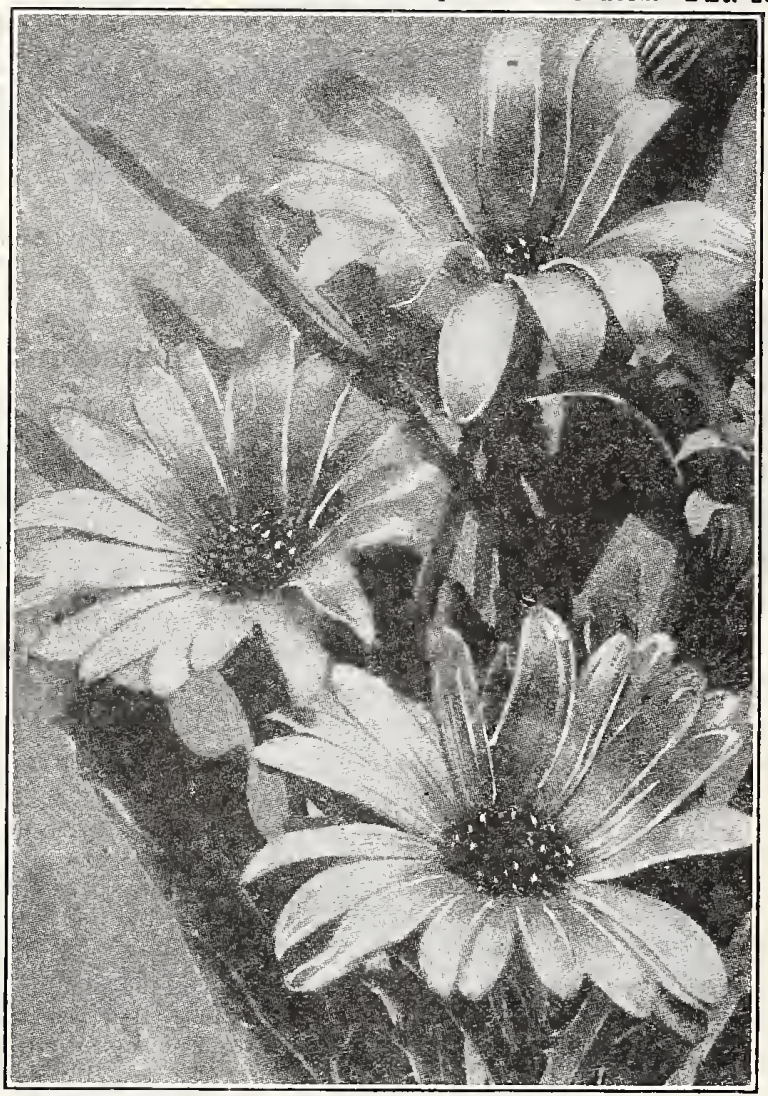

Dimorphotheca

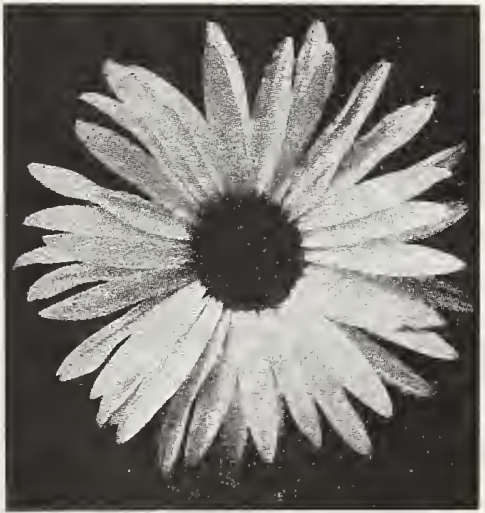

Common Shasta

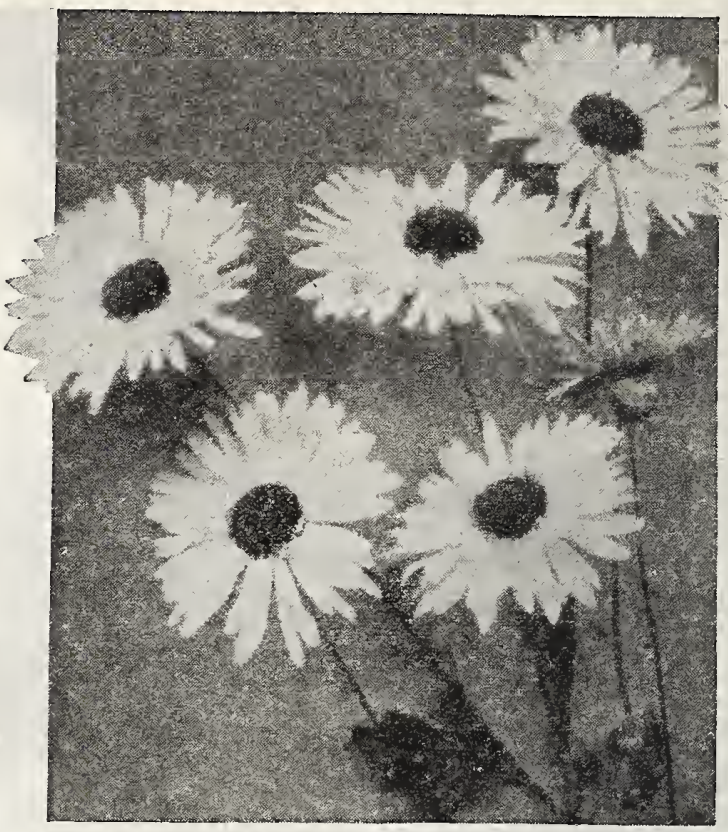

The Very Beautiful Shasta Daisies (Burbank)

Shasta Daisies, Burbanks (No. 160) One of Burbank's hybrids, a perfectly hardy perennial, bearing flowers averaging 4 inches in diameter, on long, stiff stems. It blooms freely for several months, and the flowers remain fresh for two weeks or more after cutting. The petals or rays are pure glistening white. The Shasta Daisy is one of the most useful flowers for bouquets. Pkt. 15c, oz. \$2.00.

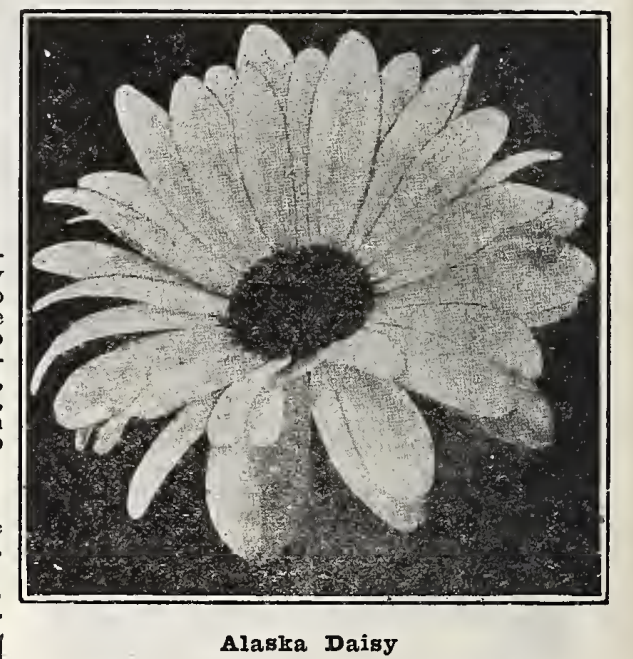

Alaska (Shasta) (No. 162)

A strong but compact-growing variety; flowers pure, glistening white, four to five inches in diameter; very free flowering. Two and one-half feet. Prt. $10 \mathrm{c}$.

\section{Old Fashioned Flower Garden Collection}

(The kind mother used to grow.) 10 Full Sized Packets for 50c postpaid. Haven't you often wished for an oldfashioned flower garden like the one at the old home? Here is an opportunity to fulfll your heart's desire. Ten full sized packets of the flowers mother used to grow-zinnias, Canterbury bells, corn flower, sweet alyssum, ageratum, larkspur, balsam, columbine, snapdragons, and hollyhocks.- All for 50c. 
Cosmos GIGANTIC FIOWFRING "IADY IENOX"-Thi bears gigantic flowers, with wide, overlapping petals of splendid substance, making a perfectly circular flower, which is borne on very long stems. The plant is of strong, vigorous growth, 6 to 7 feet high.

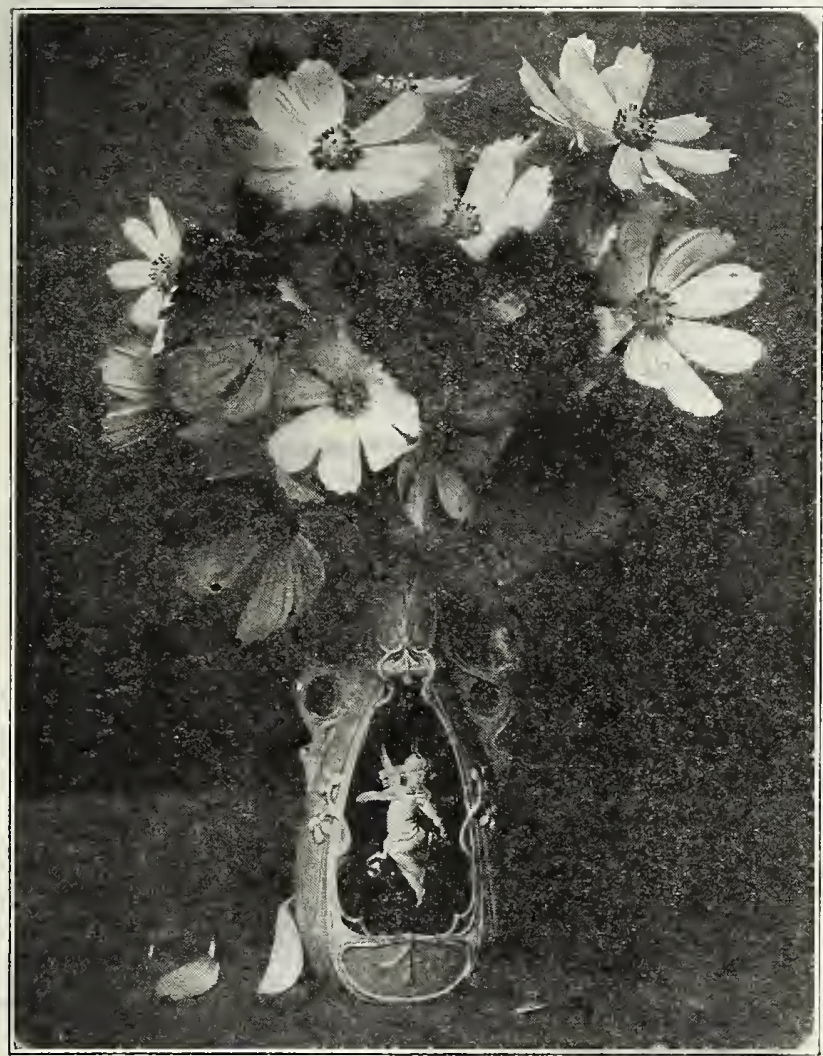

Cosmos

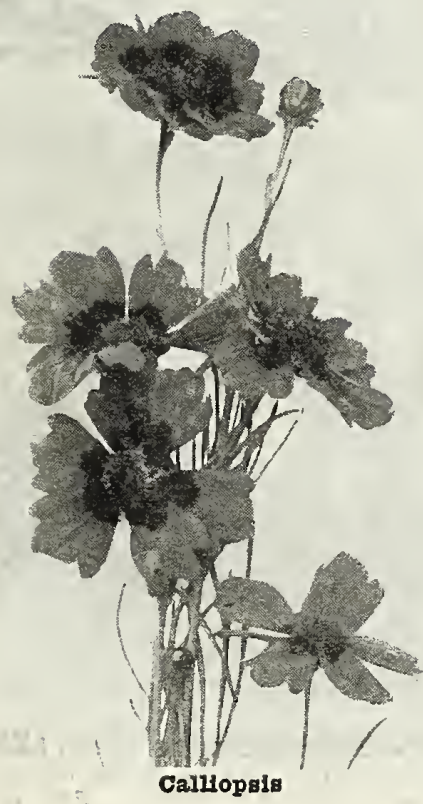

(No. 157)-L a d y L e nox, Pink ...........Pkt. 10c (No. 158)-Lady Lenox,

White .......... Plst. $10 \mathrm{c}$ (No. 159)-Lady Lenox,

Mixed ...........Pkt. 100

\section{Sun-Up Mixture}

No. 377 moth flowering cosmos including all the

bright colors. Irarge

Plst. 15c.

\section{Calliopsis Half - hardy} quick growth and bearing a profusion of bright-colored flowers.

CORONATA ( No.123) Brightest yellow flowers, of large size, deepening to rich orange and punctuated with maroon. Pkt. 6c.
A mixture of mam-

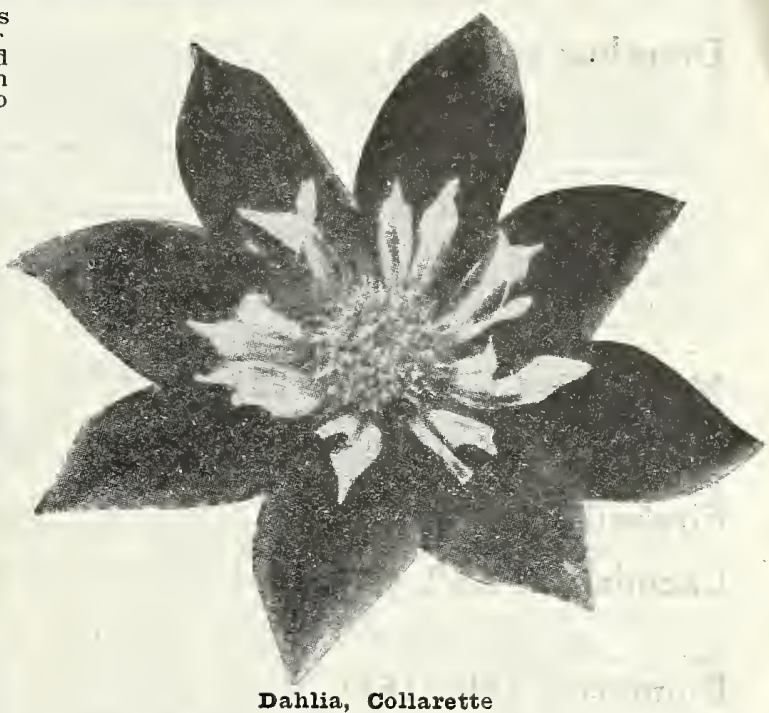

Dahlia If sown early, they will produce flowers the Danlia first season. Dig up the bulbs in the fall, (NO, 174)-CACTUS VARITTIFS, CHOICDST MTXFDMost popular at the present time; distinct and elegant; petals pointed; blooms perfectly double. Pkt. 10c.

(No. 175) COLLARETTE, MIXED COLORS-Flowers of various colors, adorned with a collar of small petals around the center, novel and beautiful. Prt. 10c, oz. $\$ 1.00$.

IARGF-FIOWERING DOUBIE MIXID (NO. 176)Plat. 10c, oz. $\$ 1.25$.

SINGIE FINEST MIXED (No. 177)-Very showy and fine for cut flowers. Pkt. 10c, oz. $\$ 1.00$.

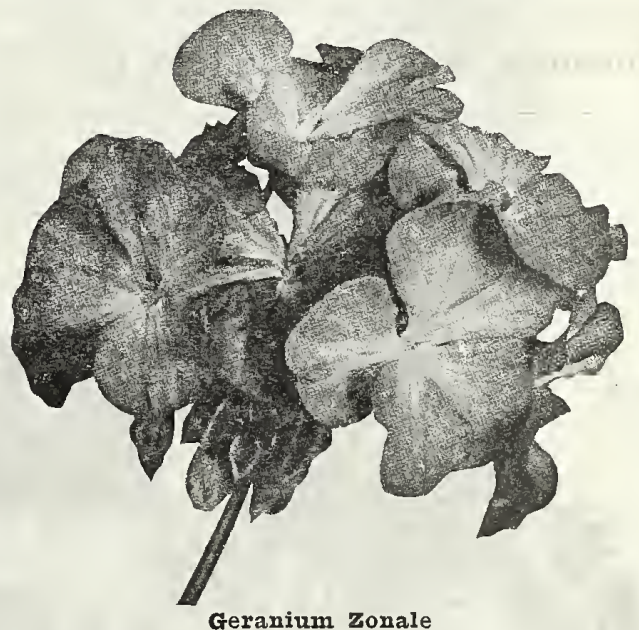

Geranium, Zonale Mixed (No. 178)

A superb strain of the largest and finest varieties. Very interesting to grow from seed, which should be started indoors and transferred to the open in May or June. Many new and odd colors are often produced from this mixture. Plt. of seed, $10 c$.

\section{Feverfew, Double White (No. 156)}

Bushy annual, bearing double, white, button-like flowers in profusion. Excellent for cutting and for bouquets. Plt. 6c. 
Dianthus or Pinks A magnificent genus, embracing in cultivation, producing a great variety of brilliant colors and profusion of bloom The varieties classed as annuals are really biennials, but are treated as annuals and may be sown out of doors when danger from frost is past, and in the are a mass of bloom, corvive the winter if given slight protection, flowering abundantly the following season. They grow about a foot high and can be used in beds or borders of solid or mixed colors. The double-flowering sorts are almost as fine as Carnations for cutting. They are not particular as to soil, but should have a suiny location. Double Pinks

Mourning Cloak (No. 163) (White Frill.) Rich, crimson, margined with pure white. Plst. 10c, oz. \$1.00. Snowball (No. 164) for cutting or as a border. Fkt. 10c, oz. \$1.00.

Fireball (No. 165) $\begin{aligned} & \text { Rich, blood-red flowers. Makes a } \\ & \text { striking contrast to the pure }\end{aligned}$ white variety snowball. plet. 10c, oz. \$1.75.

Laciniatus Fl. Pl. (No. 166) (Double Fring ed ble, showy flowers, with fringed edges, in a great variety of colors, including beautifully striped sorts, mixed colors Per $1 / 4$ oz. 30c, Pkt. 6c.

Plumarius (No. 167) (Double Hardy Ga rden double varieties in beautiful colors, 1/4 oz. 50c, Plst. 6c.

Heddewigii Fl. Pl. (No. 168) (Double Japan mixed. Colors varying from the richest velvety crimson to the most delicate rose. Plrt. 6c, oz. 80c.

Chinensis Fl. Pl. (No. 169) ( $\mathrm{Ch}$ in a or I n d ia n ters, flowers very double and in a large range of bright colors. Plt. 6c, oz. 75c.

\section{Single Pinks}

The flowers are single, with extra large, deeply fringed petals, measuring two and one-half to three inches across. In coloring the flowers range from pure white to richest Vesuvius (No. 170) $\begin{aligned} & \text { Brilliant geranium-red, makes } \\ & \text { a very effective bed or border. }\end{aligned}$ Pkt. 10c, oz. \$1.25.

Crimson Belle (No. 171) Rich, velvety crimson. Nobilis (No. 172) $\begin{gathered}\text { (Royal Pinks.) Selected and im- } \\ \text { proved varieties of the popular }\end{gathered}$ single flowering Japan Pink. The colors vary from white Chinensis, Single Mixed (No. 173) ${ }^{\text {Prt. }} \begin{gathered}\text { 6c, oz. } \\ \text { Chc. }\end{gathered}$

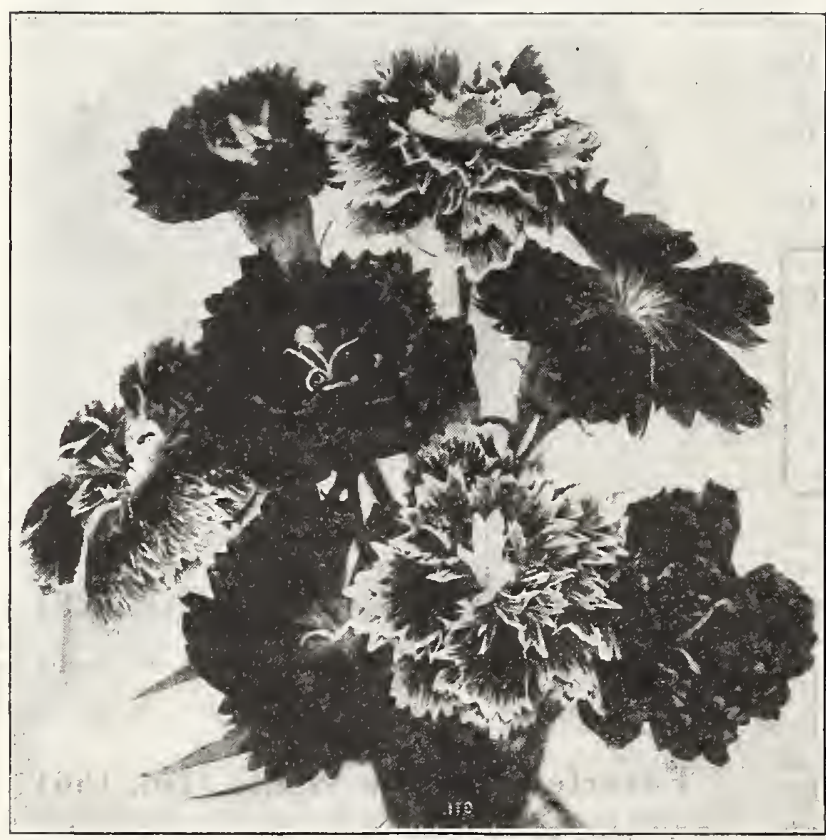

Pints, All Sorts Mixed

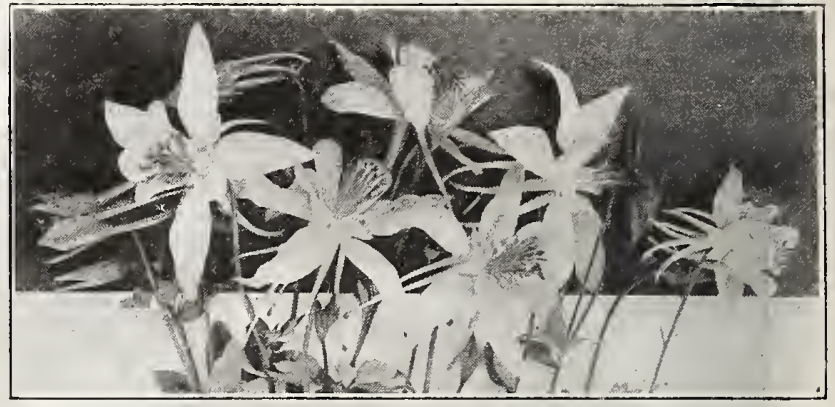

Aquilegia (Columbine) Blooms very early in the in height. Perennial. CFOICE DOUBLY MLIXID (No. 122)-Beautiful and varied colors. Pkt. 6c.

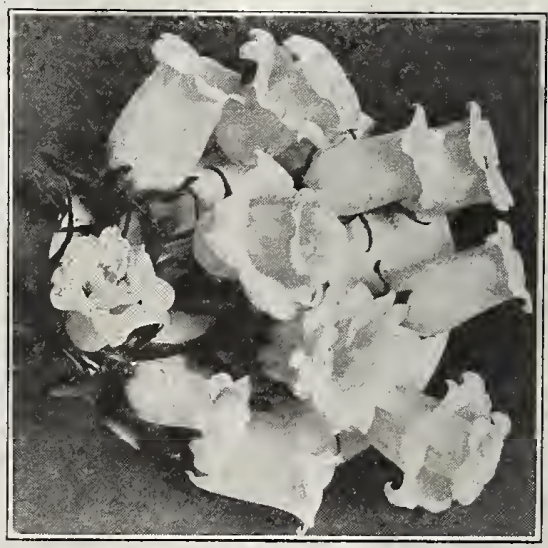

Campanula (No. 128) CANTrRBury E E I I Smental garden plants, with large, bell-shaped flowers of attractive colors; $21 / 2$ feet. Single mixed. Perennial. Plit. 6c.

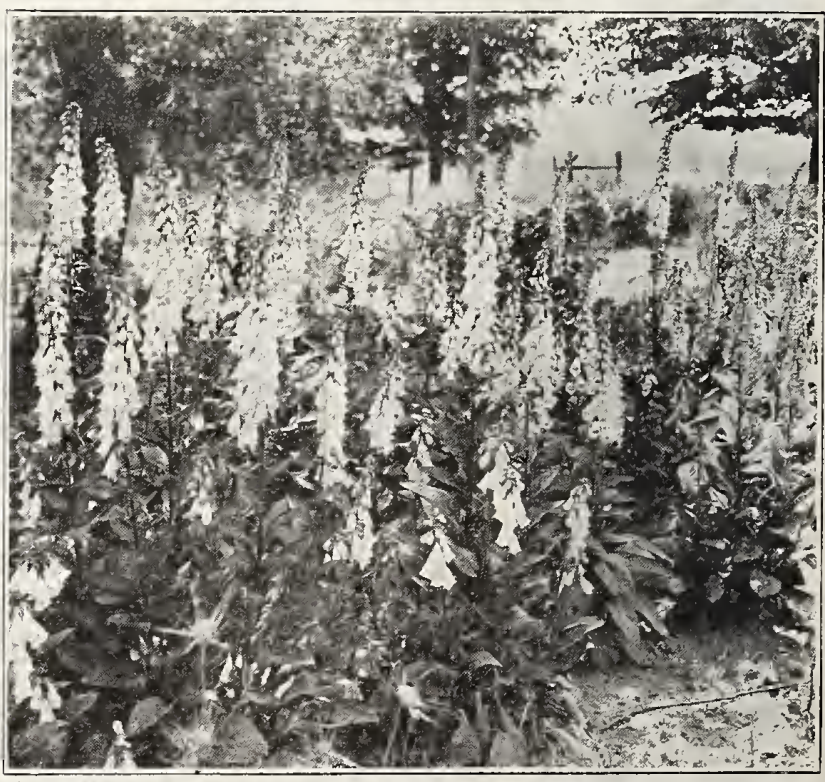

Digitalis Foxglove Gloxiniaeflora (No.125)

Handsomely spotted, gloxinia-like flowers, borne on long spikes. An extra fine strain. All colors mixed. Flt. 10c. 


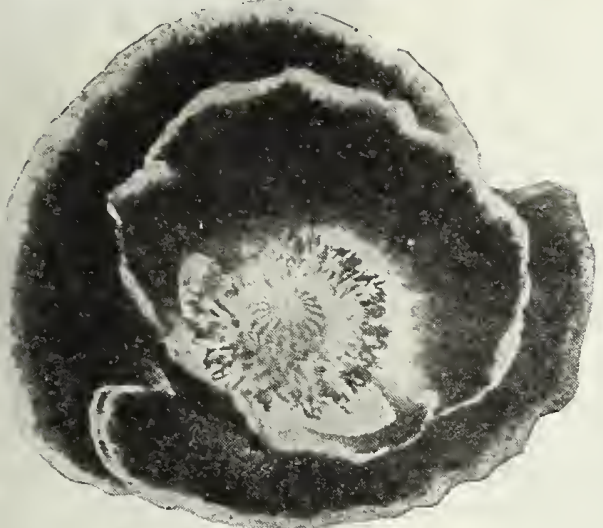

New California Poppy

Eschscholtzia (New California Poppy) Very attractive beds, edgings or masses; profuse flowerings, fine-cut, glaucous foliage: in bloom from May to frost: the Golden sorts and the blue Larkspur or Cornflower form a beautiful combination; $1 \mathrm{ft}$. Plant in January in open ground.

Alba (No. 179) Pure white. Pkt. 6c, oz. 30c.

Golden West (No. 180) Bright y el1ow, with large-rayed petals. Plit. 6c, oz. 30c.

Carmine King (No. 181) Carmine rose on both sides of Mandarin (No. 182) $\begin{aligned} & \text { Inner side of the petals rich orange, the } \\ & \text { outer side brilliant scarlet. Pkt. 5c, oz. 50c. }\end{aligned}$ Burbank's Crimson (No. 183) Taking a California Poppy gestion of crimson, Mr. Burbank, by patient and long continued selection, has produced and fixed this beautiful crimson poppy. Prt. 10c,
oz. 50c.

Golden Gate Mixture (No. 375) An entirely new mixpoppies. All colors. Iarge pkt. 15c.

Four O'Clock (Marvel of Peru) Choice Mixed (No. 184) This is another good old-fashioned flower ers during the season of white, yellow, crimson and violet. Some varieties combine two or more of these colors in spots. flakes and splashes in such a manner as to give the flowers a most bizarre effect. Pkt. 6c.

Hollyhock One of the showiest of hardy garden plants. For forming a background for other flowers we know of ck nothing better. Seeds sown early in the summer will produce plants that will bloom the following summer. Allegheny Hollyhocks are a Japanese strain, with single and semi-double, beautiful fringed flowers.

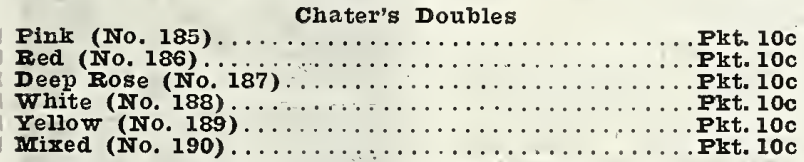
MAMIOTH ALIEGHENY (No. 191)-Finest mixed. Pkt. 10c.

EVERBIOOMING ANNUAT HOTIYHOCK (NO. 192)Plants from March sown seed, will bloom in July when about 4 feet high, but improves greatly the second year. Plet. 10c。

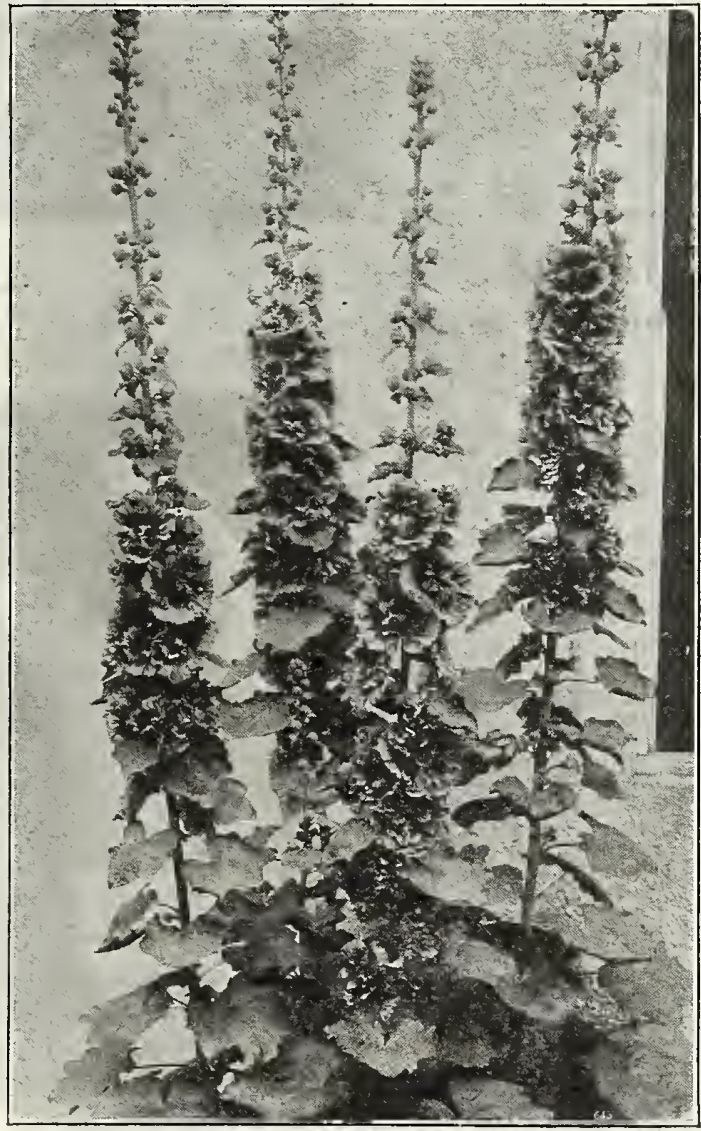

Eollyhocks

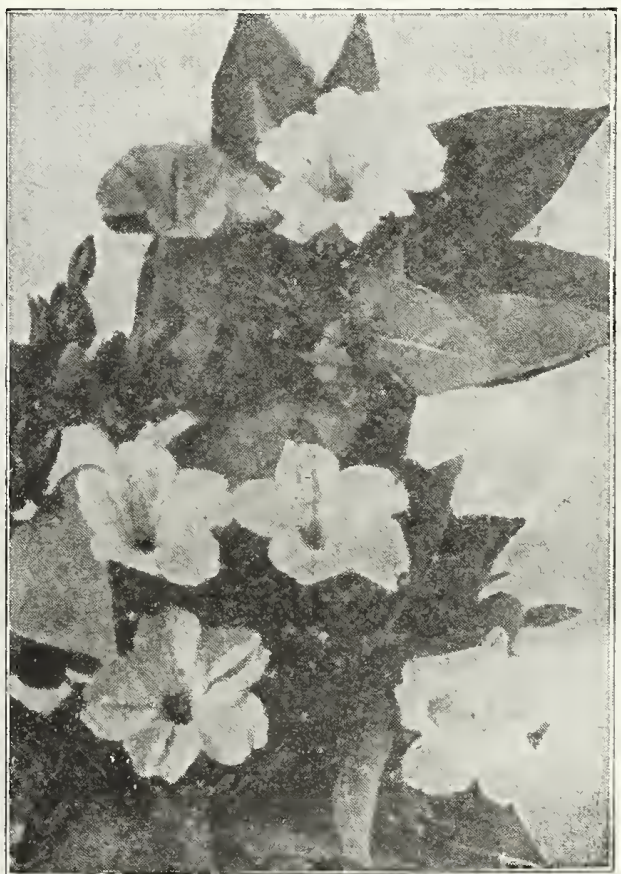

Four O'Clocks

\section{Double-Flowering Baby's Breath (No.153)}

(Gypsophila paniculata fl. pl.)

One of the most important hardy perennials of recent introduction. The plant grows from 3 to $31 / 2$ feet high, bearing its pretty little double white flowers in muchbranched panicles, which, when cut, can be used to great advantage with other flowers or by themselves, as they retain their beauty for months. It is also a most desirable addition to the hardy border. Pist. 15c. 


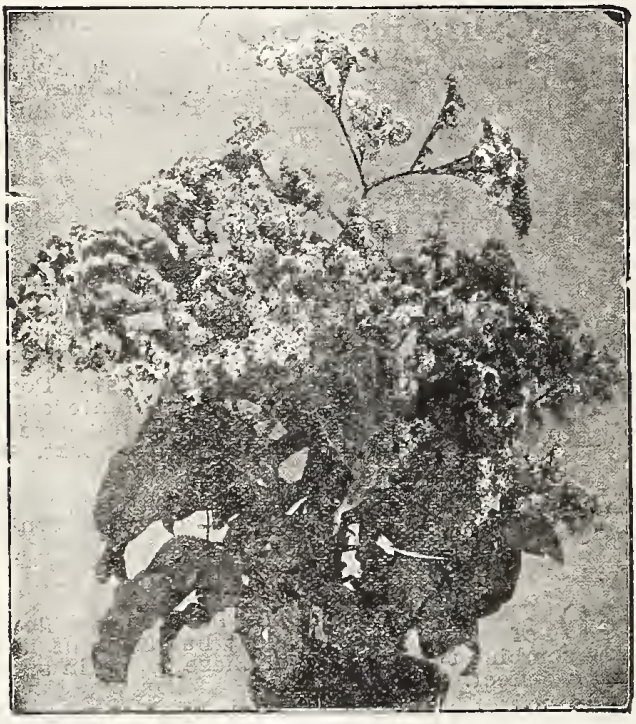

Heliotrope

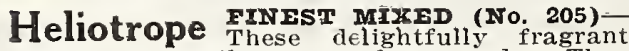
flowers are easily grown from seeds. They desirable for bouquets. Pkt. 100.

\section{Nicotiana Sanderae (No. 206)}

(Carmine-flowered robacco Plant)-The plants grow about 3 leet high, are bushy and very are tube-shaped and of brilliant carmine-red are tube-shaped and of brilliant carmine-red
color. As easily grown as petunias. Plt. 10c.

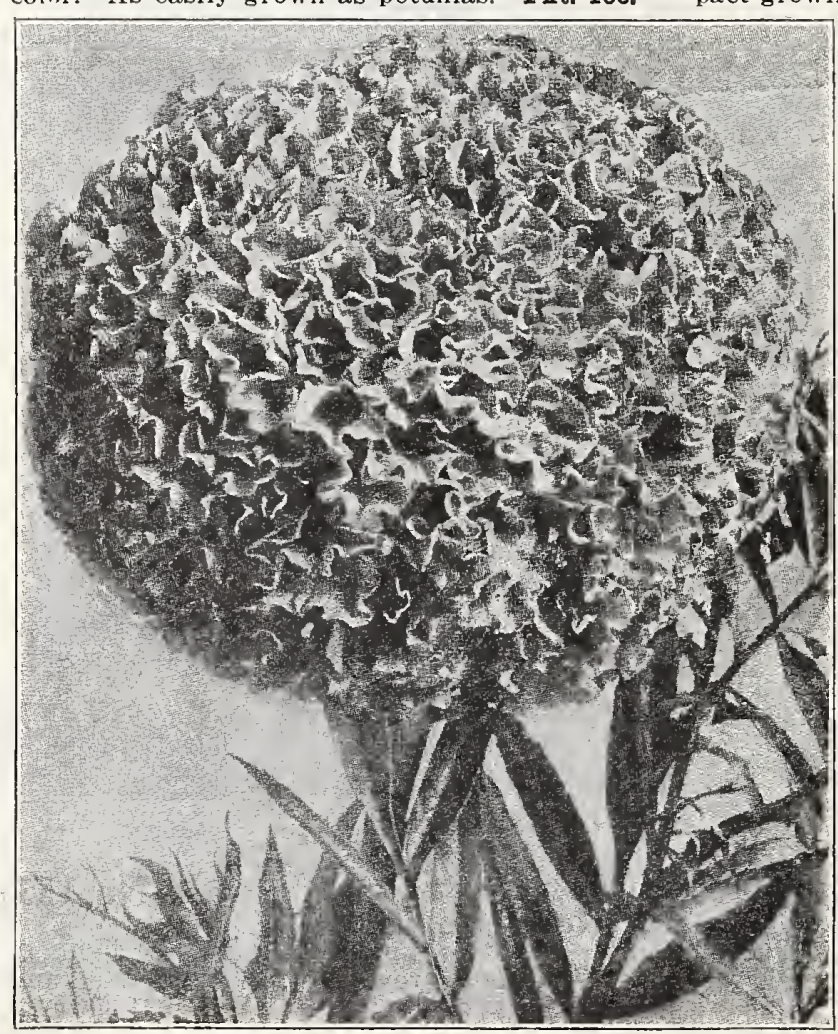

Giant African Marigold all colors
Larkspur Beautiful plants. The very free bloomers, and produce large spikes of flowers, white, pink, rose, light blue, dark blue, and violet. The ornamental, and the whole series are excellent for bouquets and table decorations. They prefer a cool soil and (No. 193)-Tall Branching.

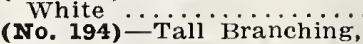

(No. 195) - Tall branching,

Purple . . . .

(No. 196)-Tall Branching,

(No. 197) - Tall Branching; (20. 198) -Tall Branching.

Pkt. 6c

PERENNIAT IARKSPUR-Belladonna (No. 199)-Everblooming
hardy flowers in profusion..Pkt. 10c

Mignonette ting on account of its fragrance; sow in succession durthe whole summer.

SWEET-SCENTED (NO. 200) (Reseda odorato) - Well known fragrant favorite, which may be the winter. It produces numerous small flower-stalks. Grows 1 foot high, Prt, EC.

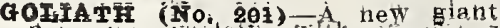
flowerlin videty; with enormous tristes of double red flowers; the A very striking variety. Pkt. 10c.

GOLDEN MACHET (No. 202)-A compact-growing variety, with meflowers. Pkt. 6c, oz. 50c.

WHITS MACHET (No. 203) -A compact-growing variety, with thick spikes and large size flowers. Pkt. 6c, oz.

MIXTURE OF MANY SORTS (No. 204)Pkt. 6c.

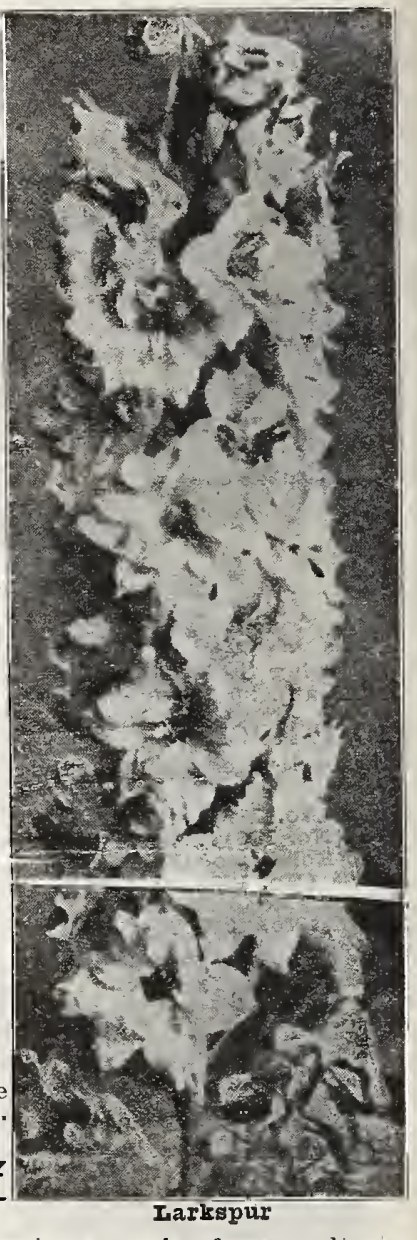

Marigold Free-flowering annuals of easy culture. borders. Well adapted for large beds or mixed PRINCE OF ORANGE (No. 207)-This very distinct variety has large double golden yellow flowers, the petals striped or shaded dark orange; abundance. Height of plant, about one and one-half feet. Pkt. 10c.

D W A $\mathbf{R} \mathbf{F}$ G O I $\mathbf{D}$ STRIPED (No. 208) -Double, brownish red striped golden ioc, $1 / 2$ oz. $40 \mathrm{c}$.

IEMON QUEEN (NO. 209)-Flowers 2 to 3 inches in diameter. ored. Pkt. $5 c$.

GIANT A FRICA N D O U B I $\mathbf{E}$ IMIXED (No. 210)-Grows 2 and 3 feet high. The and 3 feet high. The ble, measuring about 3 inches in dlameter. The colors are orange, brown, yellow. Plt. 5c.

FRENCF DOUBIE MIXED (NO. 211) All colors. Ptst. $5 \mathrm{c}$, 0z. $50 \mathrm{c}$.

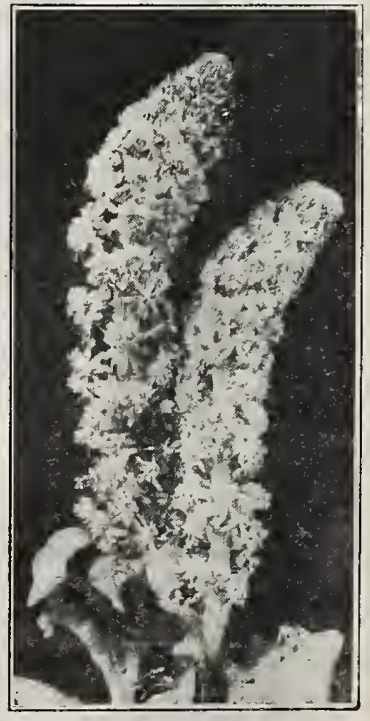

mignonette 


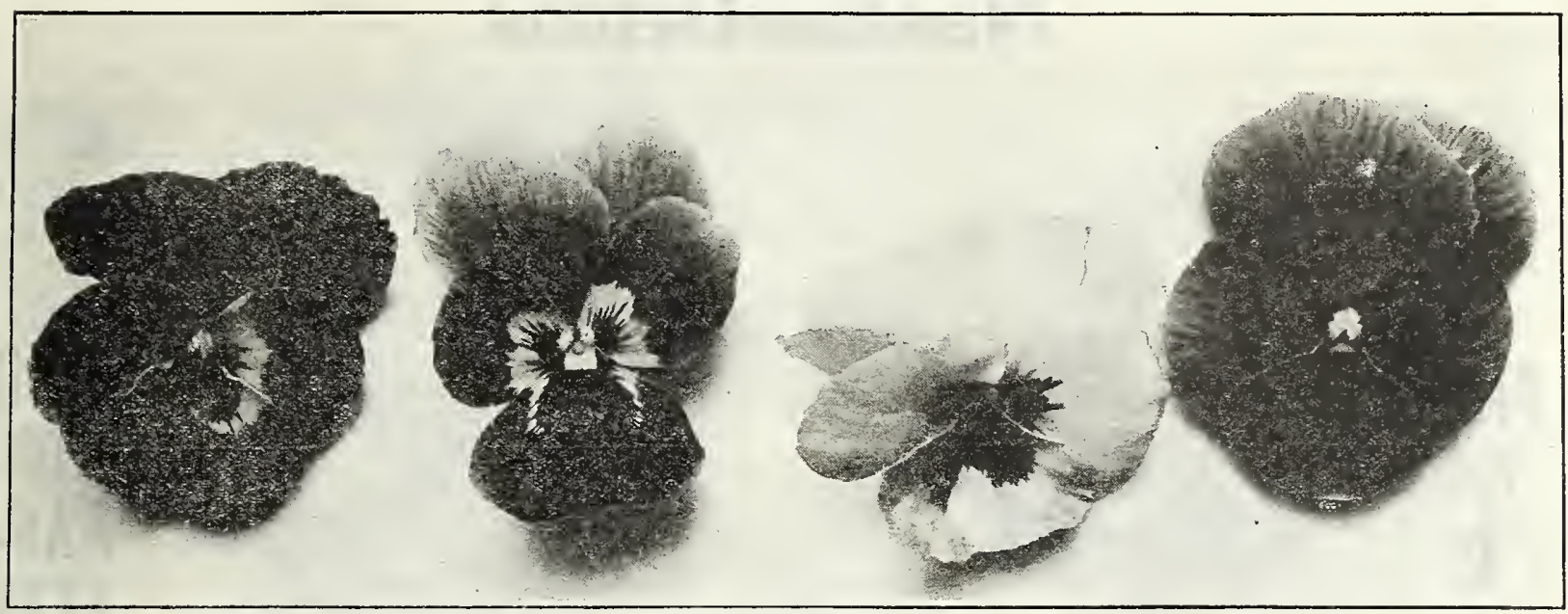

Mixed Pansies

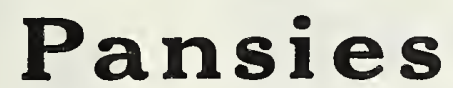

For spring flowering the seed should be sown in aumn and protected during the winter. For summer blooming sow in January and February, and plant out where they will have some shade from noonday sun. Pansies require fresh soil, plentifully enriched with well-decomposed manure.

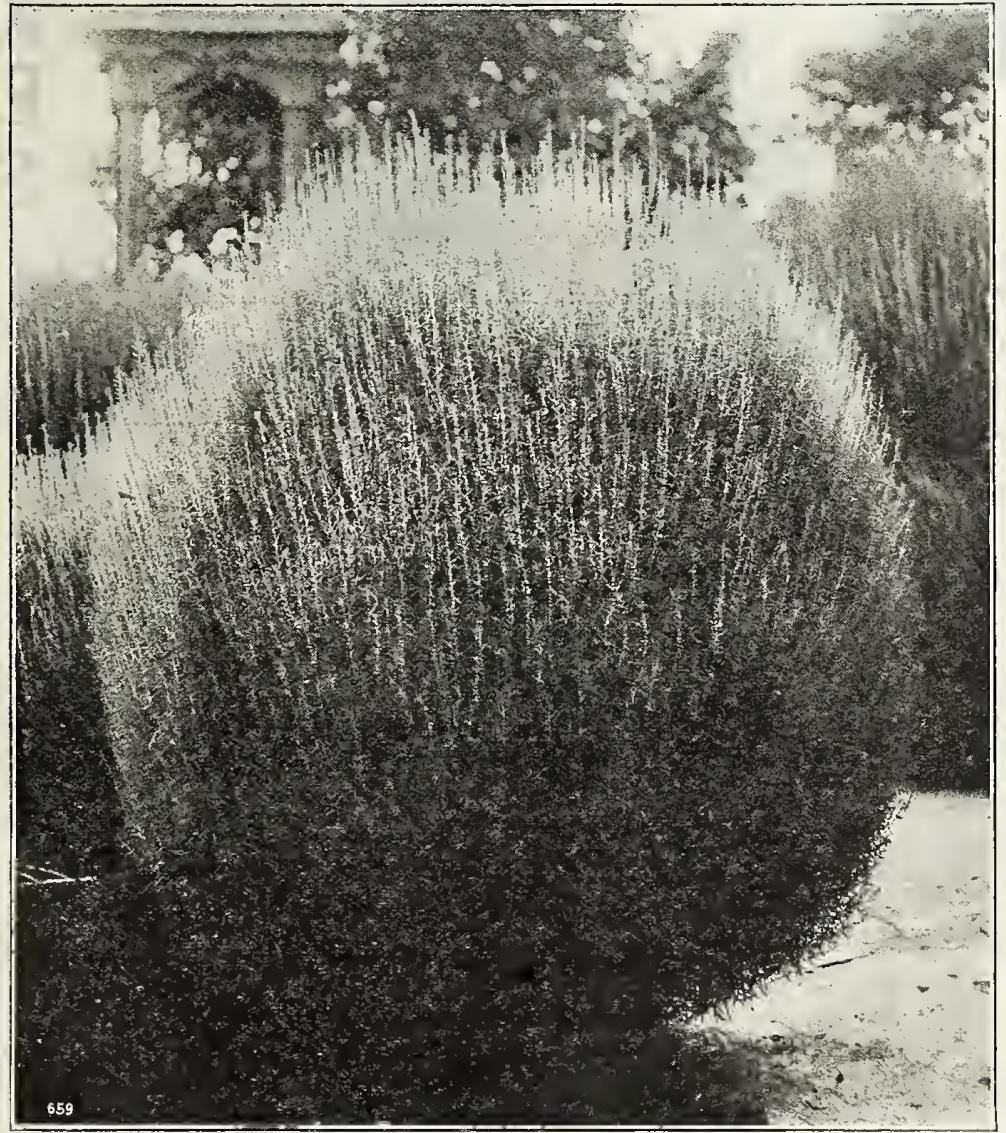

Kochia-(Mexican Fire Bush)
GIAN T TRIMARDEAU (No. 212)Flowers of enormous size. An altogether distinct and beautiful new race, the flowers of which are larger than any hitherto produced. Each flower is marked with three large blotches or spots; the plants are of compact growth and produce an endless variety of beautiful shades. Mixed. Plt. 10c, 1/8 oz. 50c.

CASSIER'S GIANT MIXED (NO. 213)splendid mixture of various shades and markings. The blossoms are perfectly round and are blotched at the base of three to five of the petals. Pkt. 10c, $1 / 8$ oz. $50 \mathrm{c}$.

GOOD MIXED (No. 214)-Many rich colors. Pkt. 8c, $1 / 4$ oz. 75c.

Kochia Mexican Fire Bush, Summer grown annual, which, sown thinly in spring, soon forms a cypress-like hedge of the most lively green and of perfect symmetry; by midsummer it attains a height of about 3 feet, and on the approach of autumn the whole plant becomes a deep red; a splendid plant to divide the vegetable from the flower garden, or for forming a hedge for the summer for any purpose. Pkt. 10c.

Portulaca Dwarf annual of creeping growth, thriving luxuriantly in an open, exposed situation. During bright, sunny days the plants are ablaze with brilliant flowers of all shades. At night and on dull day's the Howers remain closed.

SINGIE MIXED (No. 216)-Large flowers of brilliant colors. Fkt. 6c, oz. 50c.

DOUBIE MIXED (No. 217)-Perfectly double flowers of all colors. Plst. 10c, oz. $\$ 2.00$. 


\section{Nasturtiums}

Few flowers impart such rich beauty to the garden as Nasturtiums. The colors of their lovely flowers are bright and varied and contrast well with their dark green foliage. Their duration of bloom is marvelous, and their culture is the simplest. They give a profusion of bloom in poor soil and stand hot and dry weather better than most any flower we know of. The dwarf sorts are splendid bedders, making a plant about 10 inclies high and a foot across. The tall sorts are good climbers, being excellent for covering unsightly places, and trailing over bare, rocky spots, or climbing fences or trellises. The seed pods have a pungent flavor and are much used for pickling and seasoning. We are offering the best and newest varieties, and hope everyone will try a few of them. You will find our prices on them are very low.
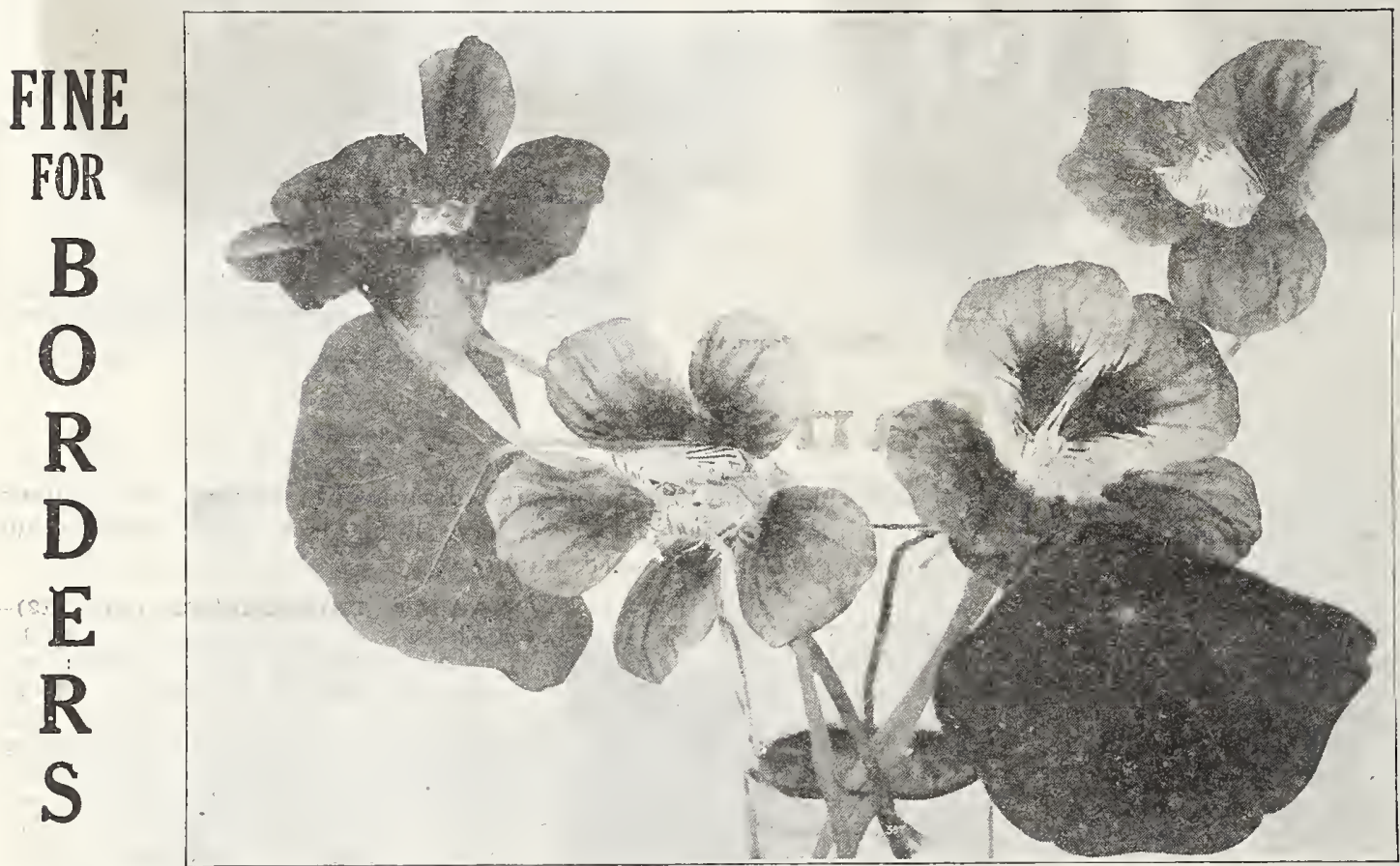

FINE FOR BASKETS AND

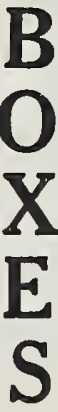

Ta.11 Nasturtiums Packet

TAII PRINCE HENRY (No. 218) - Light yellow spotted scarlet.................\$0.06 \$0.25

TALI CHAMELEON (No. 219)-Varied colors on

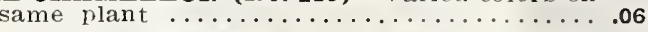
TAII SCARIET (NO. 220)-Intense scarlet,

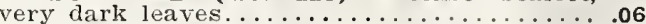
TAII FORDHOOK FASHION (No. 221)-FIOWers ecru overlaid with old rose...........06

TAII SCHUIZI (No. 222)-Deep red........06 TAII SPOTTFD (No. 223)-Yellow, spotted galnet .06 TAII KING THEODORE (No, 224)-Crimson

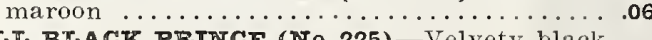
TAIJ BLACK PIINCE (No. 225)-Velvety black

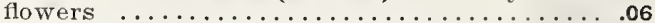
TAER IJMON YILIOW (No. 226)-Clear yelTAII CRIMISON (No. 227) -Beautifui shade... .06 TAII MIXED, AII BRIGIT COIORS (No. 228)-A wonderful mixture of the brightest TALI MIXID (No. 229)-Ail sorts. Ib. $\$ 1.75 \ldots .06$ Dwarf Nasturtiums

(No. 230) IMPRESS OF INDIA-Intense crim(No. 231) CIYSTAL PAIACE Grir-sulphur 06 (खNo. 232) BEAUTX-Scarlet, splashed canary... (No. 233) CIOTH OF GOLD-Yellow foliage,

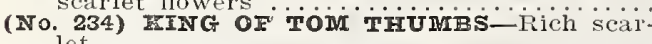

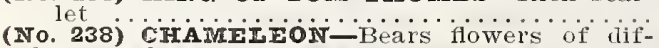
(No. 238) CHAMEEEON-Bears fowers of tif-

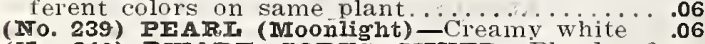
(No. 240) DWARI SORTS MIXED-Blend of finest named varieties. Pound $\$ 1.75 \ldots \ldots \ldots .06$ (No. 235) AURORA-Yellow, stained crimson... 06 (No. 236) BRONZE-Flowers a silky bronze.... .06
Dwarf Nasturtiums

(No. 237) OUFEN OF TOM THUMBS, VARI FGATED IEAVED-Crimson flowers with variegated foliage...........\$0.06 $\$ 0.30$
.25

.25

.25

.25

.25

.25

.25

.25
.25

25

.20

.25

.25

.25

.25

.25

.25

.25

.20

.25

.25
Ivy-Leaved Nasturtiums In this type the rich, is similar in shape to the well-known English Ivy, and forms a beautiful backglound to the flowers, many of which are fringed or laciniated, while the colors are as varied as in the ordinary sorts.

DWARF IVY-IFAFED (No. 241)-Makes pretty, compact plants, excellent for beds, borders, boxes, etc. Płt. 10c, oz. $25 \mathrm{c}, 1 / 4$ 1b. $75 \mathrm{c}$.

TAII IVY-IEAVED (No. 242)-Of strong, vigorous growth. A very attractive vine. Mixed colors. Pkt. $10 \mathrm{c}$, oz. $25 \mathrm{c}, 1 / 4$ ib. $75 \mathrm{c}$. 


\section{Petunias}

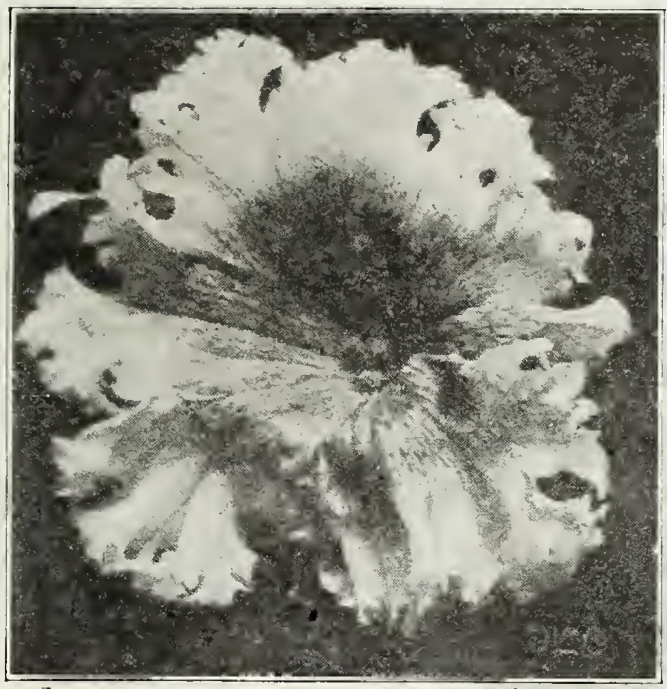

Ruffled Giant Petunia

\section{Single Bedding}

(No. 243) - Howard's "Star Petunia," compact - growing variety. Flowers cherry-red with a white center. Pkt. $10 \mathrm{c}, 1 / 4$ Oz. $75 \mathrm{c}$.

SNOWBAII (No. 244) -A fine, compact sort, producing its pure satiny - white flowers throughout the entire season. Plet. 10c, $1 / 4$ oz. 60c. ROSY MO R N (No. 245) - This is a very a great number of flowers which are a brioht rosy pink with white throat. The plants are small and compact and flower mos: freely. Pkt. 15c, $1 / 4$ oz. $75 \mathrm{c}$.

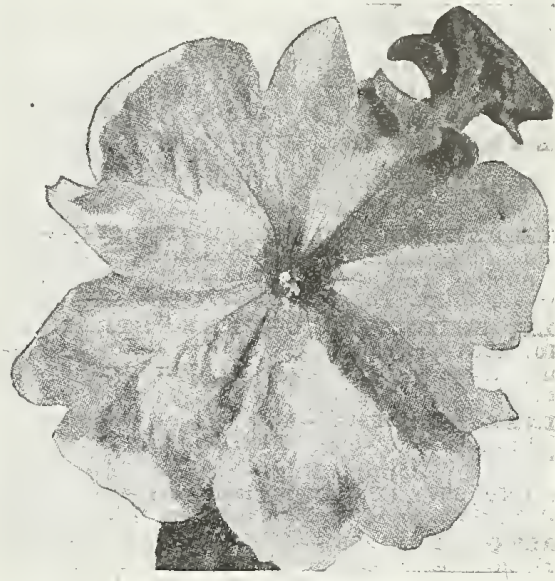

Foward's Star Petunia

FINE MIXED (No. 246)-Good bright colors. Pkt. 10c, 1/4 oz. 50c.

RUFFIED GIANT (No. 248)-Flowers of extraordinary size and substance, and distinguished from the largeflowering fringed section by the deep fluting, giving the appearance as if artificially ruffled. Pkt. 25c.
GIANTS OF CAIIFORNIA (No. 249)-Flowers very large, in great variety of colors and markings, with deep yellow throats. Per Plt. 25c.

SINGIE COUNTESS OF ELLSMERE (No. 247)-Pinkish lavender, white throat. Pkt. 10c.

\section{DOUBLE LARGE FLOWERING PETUNIAS}

(No. 250)-Beautiful varieties in mixture. The best that money can buy. Plt. $35 \mathrm{c}$.

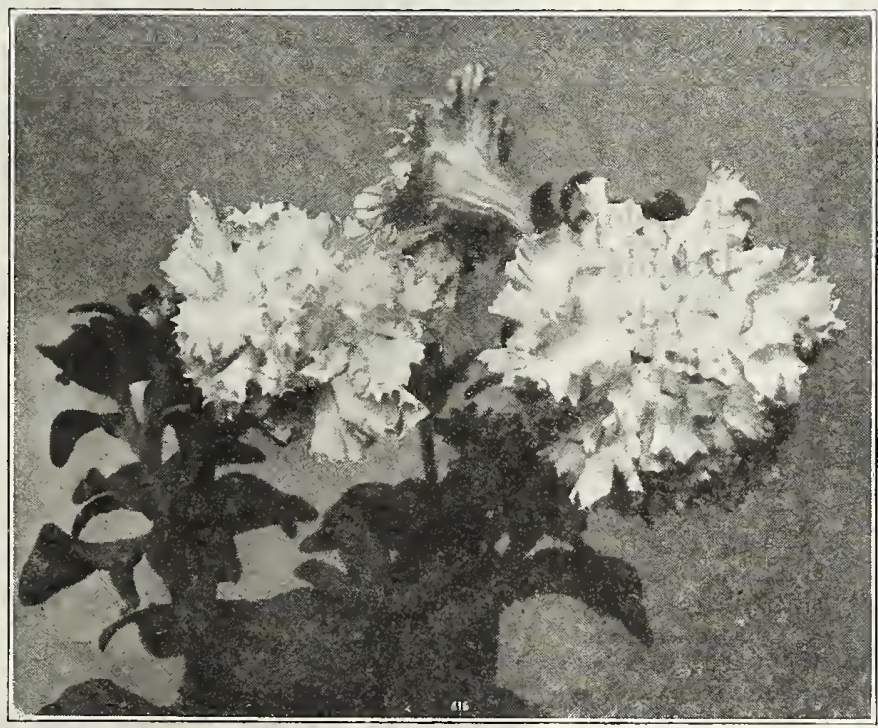

Double Iarge Flowering

NOTr.-It is well known that seed saved from the most carefully hybridized flowers produce but a small percentage of double flowers, the balance being single of unusually fine quality. The weakcr seedlings should be carefully saved, as these invariably produce the finest double flowers. The same is true of the single sorts, the large, strong seedlings usually being weedy, while the, at first, Neaker seedlings produce the very finest flowers, of the best colorings.
Lantana Well known shrubby plants flowers, and producing their pink yellow, orange and white heads in great abundance They have an agreeable aromatic perfume. EINEST IIXED-(No. 251)-Pkt. 5c.

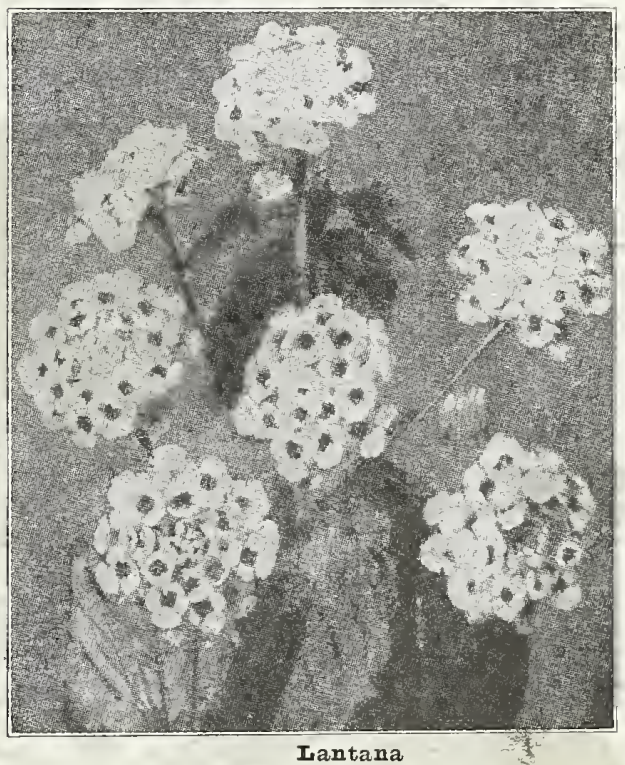

Rainbow Gladioli Collection 25 Bulbs, $\$ 1.00$ Postpaid 
Poppies Everybody loves poppies. They covered all summer with satiny flowers of silk-like texture, in many brilliant color combinations. Mix seed with sand before sowing so as to distribute the seed thinly and evenly. They should be sown in January and February.

\section{Poppy, Double}

AMIRICAN FIAG (No, 252)-White margined and striped red. Pkt. 6c, oz. 30c. WHITE FRINGPD (No. 253)-Perfectly double, ball-like, round flowers, measuring 3 to 4 inches across. One of the finest in cultivation. Pkt. 6c, 0z. 55c.

DOUBIE PAEONY-FIOWFRED (NO. 254)Fnormous double flower of many shades of purple, red, pink, yellow and white, Mixed, Pkt. 6c, oz. 20c.

DOUBIE SHIRIFY, BURBANT STRAIN (No. 255)-Hitherto unknown shades of blue, lavender and salmon. Pkt. 10c, oz. $75 \mathrm{c}$.

CARDINAI (No. 256)-Very large, double cardinal-red flowers. Pkt. 6c, oz. 40 c.

$$
\text { Poppy, single }
$$

TUIIP (No. 257) (Papaver glaucum)-Splendid vivid scarlet. Pkt. 6c, oz. 75c.

MEPHISTO (NO. 258)-Richest vermilion, with a deep, shining black spot at th base of each petal. Pkt. 10c, 0z. $\$ 1.00$.

VIRGINIA (No. 259)-Large, beautifully fringed flowers on pure white, edged with soft pink; exquisite when cut. Pkt. 6c, oz. $35 \mathrm{c}$.

FIRE DRAGON (No. 260)-Very showy flowers of brilliant de€p scarlet, with black spots, margined white; 2 to $21 / 2$ feet. Per Pkt. 6c, oz. 35c.

SHIRIEY POPPY (No. 261)-Many delicate shades of rose, pink, carmine and brilliant crimson. Many flowers are edged with white. Pkt. 6c, oz. 35c.

DANEBORG (DANISF FIAG) (No. 262)-Carmine, with a white cross in the center. Plit. 6c, oz. 30c.

MAID OF THE MIST (No. 263)-Pure White, of perfect form. Plit. 6c, 0z. 30c.

FNGISH SCARIET (No. 264)-Immense scarlet. Pirt. 6c, oz. 25a

Ricinus (Castor Oil Bean) ZANZIBARIFNSIS (No. 267) 20 feet high in season foliage, plants growing from 15 to measuring sometimes 2 feet across. Forms excellent screen for unsightly places. Pkt. 10c.

MXIPD (No. 268)-Many varieties. Pkt. 6c, oz. 20c.

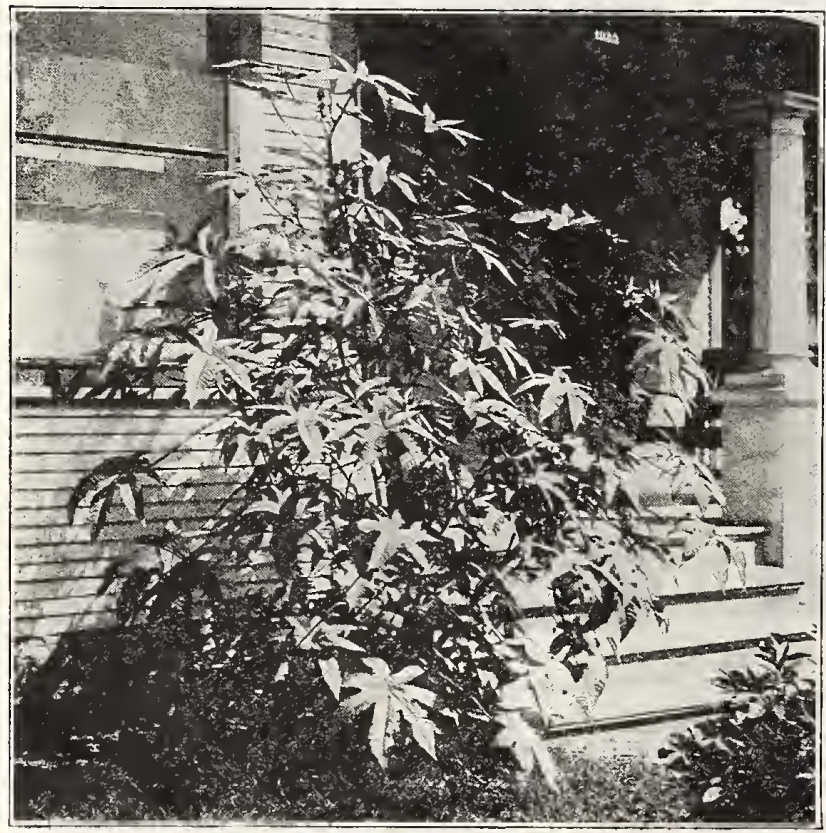

Ricinus (Castor Oil Bean)

\section{All Color Double and Single Poppy Mixture}

This is without doubt the most beautiful mixture of Poppies Q v e $r$ offered. Irarge pkt., $15 \mathrm{c}$.

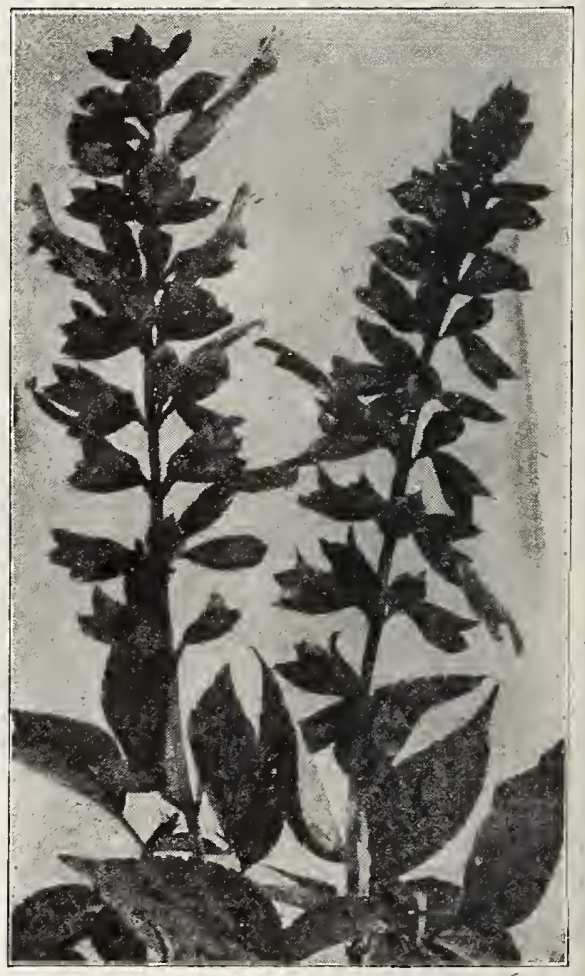
Salvia Splendens 


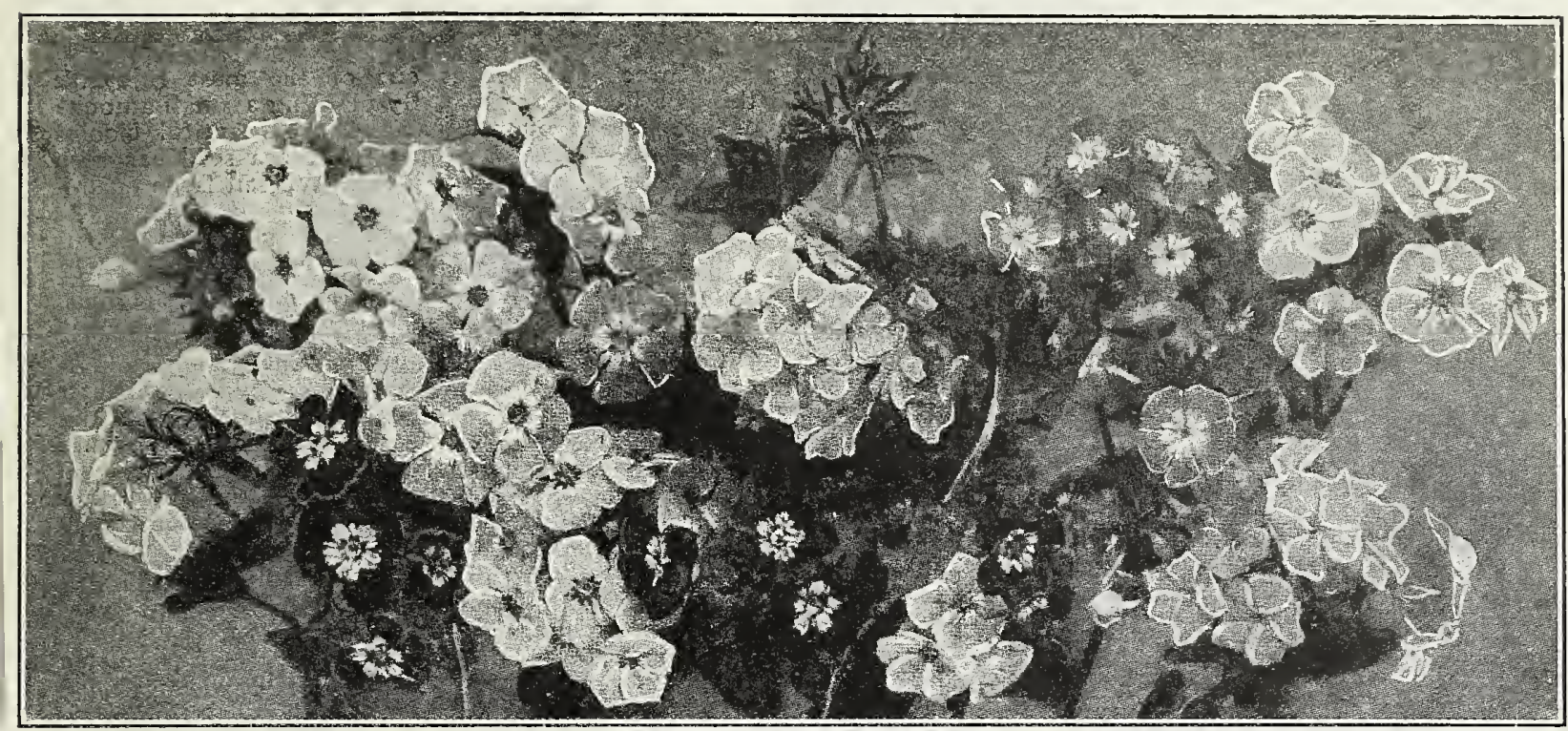

PHIOX-TEXAS PEIDE

PHIOX DRUMMONDI GRANDIFIORA-The a n $\mathrm{n}$ u a 1

Phlox is a native of our state, and is known as "Texas Pride." Phlox occupies a first place as a garden annual, being the showiest and most easily raised. We know of nothing that prive flowers in such a wonderful range of coiors. It will grow and thrive in any kind of soil if given a sunny position. Seed may be sown in the open ground any time after danger from frost is past, and in a few weeks they are a sheet of bloom. remaining so until frost. Seed is very scarce this season. If we are not able to supply colors, will send mixed. If you do not want mixed, be sure to tell us.

CHAMOTS ROSE (No. 269), salmon pink, orange eye...10c CARnea (No. 270), brilliant pink............... SPLENDENS (No. 271), blood red, with white star in..

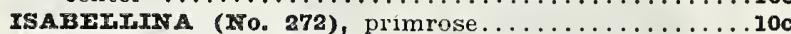
ALBA (No. 273), white..................10c MXX̃D (No. 274), all colors, oz. \$1.25...........10c

STAR OF QUIDIINBURG (No. 275), star-shaped flow-

ers of many colors... .

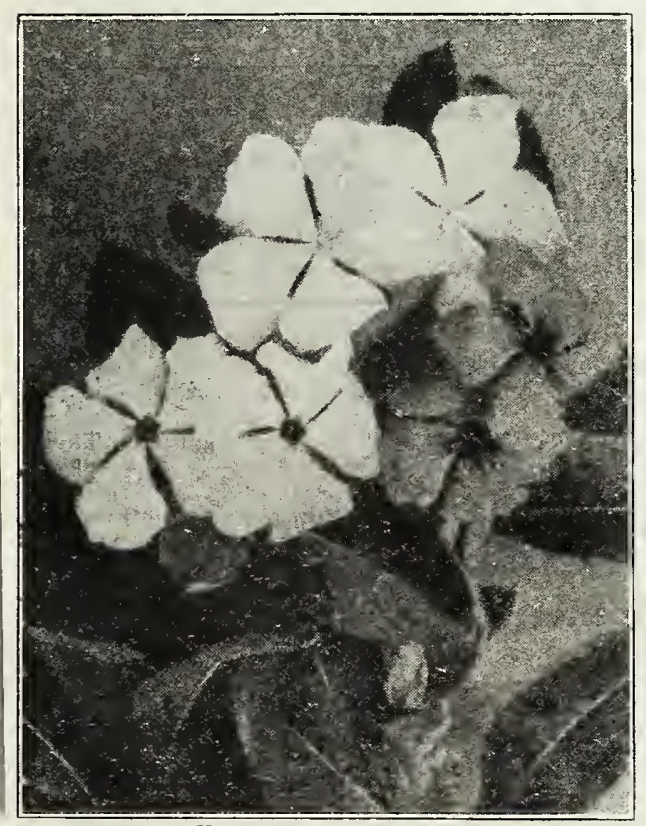

Vinca (Madagascar

A tender perennial plant blooming the first season. A d a p t e d to window or open garden, making a fine show in the border. Height 18 in $\mathrm{ch}$ es. Flowers $11 / 2$ inches across.

Alba Pure white .....10c Rosea (No. a77) -

....10c Rosea Alba (No. 278)

eye .............. Mixed (No. 279)...10c

\section{Wallflower}

Doubie Mized (No. 280) This mixture embraces the best colors of these old Eurobining many shades. The dark colors predominate. They are scarcely hardy in cold locations, bu generally withstand the cold of our Southern climate

vinca or Feriwinkle very well. Pkt. 10c.

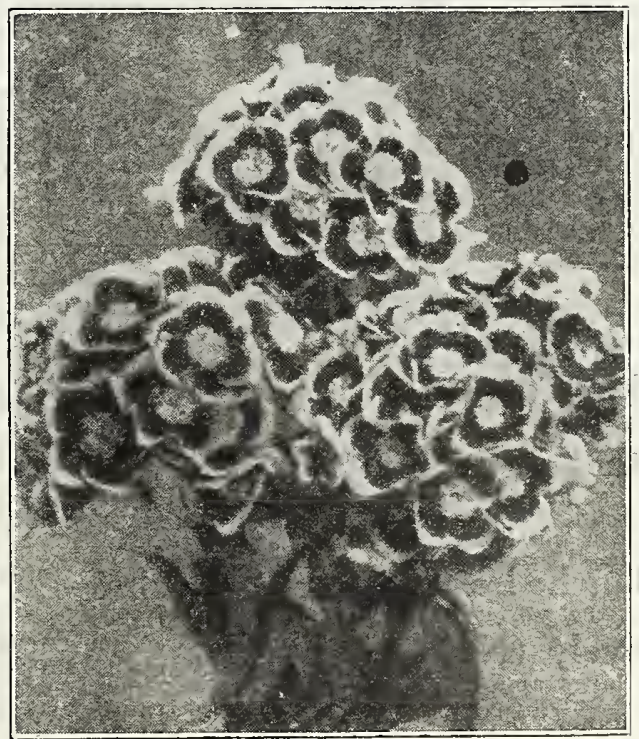

Sweet William (Dianthus Barbatus)-Unsurpassed for massing beds or borders. Produce an abundance of richly Weet throughout the season. Fine for cutting. 2 feet. Hardy perennial FINEST SINGIF MIXED (No. 283)-Beautifully shaded and marked. Pkt. 6c, oz. 65c. FINEST DOUBIE IIIXED (No. 284)-Splendid strain. All colors. Pkt. 10c, oz. 75c.

Stocks, Ten Weeks, White Perpetual (No. 281) (Princess Alice, or Cut-and-Come Again)-Pure flower clusters The flowers are delightfully fragrant and keep well after cutting. $\mathbf{P r t}$. 150 , 1/4 oz. $\$ 1.00$. BEAUTY OF NICE STOCKS (NO. 282)-These may be sown early to bloom in summer or in July and August for later flowering. Seedlings bloom in ten weeks. Splendid for pots and cuttings. 2 feet. All colors mixed. Pirt. 10c. 


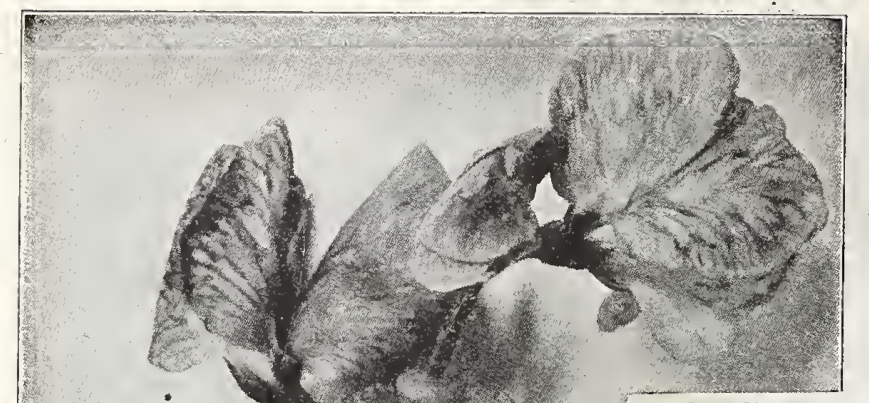

ered with more soil than when planted later. Otherwise the directions given here apply. Select rich ground and spade it deeply; then dig a trench 5 or 6 inches deep and sow your seed in it and cover with 2 or 3 inches of soil, hoeing in the balance when the plants are well started in growth. When 2 or 3 inches high the vines should be thinned to 5 or 6 inches apart, and brush or twine run from stake to stake should be provided for them to run on. In wet weather the earth should be ridged along the row, and in dry weather should be worked frequently to preserve the moisture. Always cut the flowers before they wither. Observe these directions carefully and you will have strong vines, profuse flowers and long scason of bloom.

\section{NEW AND RARE SPENCERS}

America (No. 285) Red striped white; the name is very fitting American flag.

Mrs. Routzahn (No. 286) Buff or apricot ground, flushed deepening toward the edges. The tlowers are of the largest size-thoroughly crimped and waved. The standard is broad and deep; the wavy wings are so large that they usually hide the keel.

Margaret Madison (No. 288) $\begin{gathered}\text { An exceedingly chaste va- } \\ \text { riety of unsurpassed beauty. }\end{gathered}$ The flowers are a clear azure-blue.

Hercules (No. 289) This is a beautiful new dainty pink Sweet been appropriately named Hercules. You will find this an extremely attractive variety.

Price of any of the above: Pkt. 10c, 0z. 50c, 1/4 1b. $\$ 1.50,1 \mathrm{~b} . \$ 5.00$

\section{EXTRA EARLY MIXTURE \\ (No. 378)}

As the name implies, this is a specially prepared mixture of extra early flowering varieties, including the daintiest colors. Some are light pink, dark pink, lavender, white, etc. By planting our Extra Early Mixture you will have sweet peas 3 to 4 weeks earlier, hence 3 to 4 weeks longer than ever before. We would suggest that you use this mixture for your first planting and then for a succession crop use other varieties listed on this page. Iarge plrt. (sufficient seed to plant 25 feet), 35c; oz. $65 \mathrm{c}$.

King Edward VII

\section{TEXSEED SUPERB SPENCERS}

Price of any below: Plt. 10c, oz. 50c, 1/4 lb. $\$ 1.00$, 1 b. $\$ 3.50$.

Asta Ohn (No. 291) An exquisite variety, wings clear lavender, standard pinkish mauve, of very King Edward VII Spencer (No, 292) The standard is a deep rich carmine-scarlet of glossy effect. The rosy carmine. The long stiff stems frequently carry four fine blooms.

Othello Spencer (No. 294) The flowers are The long stems are thick and carry well either three or four fine biooms of a rich deep maroon. It is a strong grower and flowers most profusely.

Blanche Ferry Spencer (No. 295) The standrose, the wings pinkish or bluish-white.

Lovely (No. 297) The color is a rich buff-pink self Lovely (No. 297) on cream ground. The flowers are large' and usually there are produced three on a stem. The standard is broad, beautifully waved and of great substance.

Special Spencer Collection (No. 381),66c. This is lection illustrated on inside front cover. The cream of the Spencers are included: one packet each King Edward (scarlet), Etta Dyke (white), Lovely (pink), Thomas Steveson (orange red), Othello (maroon), White Spencer, Asta Ohn (lavendér). America (whité, striped red). Eight full sized packets sent postpaid for 66 .
White Spencer (No. 299) Produces in the greatwhite waved flowers of large size. Countess Spencer (No. 301) This is the origwhich the entire spencer type has sprung. A soft rosepink, which deepens at the outer edges.

Mixed Giant Spencer Sweet Peas (No. 302) Composed exclusively of Giant Waved spencer varieties, blended in proper proportions of bright colors and including several new hybrids of exquisite colors and shades. Pkt. 8c, oz. 25c, 1/4 1b. 75c, 1b. $\$ 2.50$.

SWEET PEAS-GRANDIFIORA.

\section{Eckford's Hybrids Mixed (No. 303)}

Excellent assortment of choice varieties. Pkt. 6c, oz, 20c, $1 / 4$ 1b. 50c, 1b. $\$ 1.50$. 


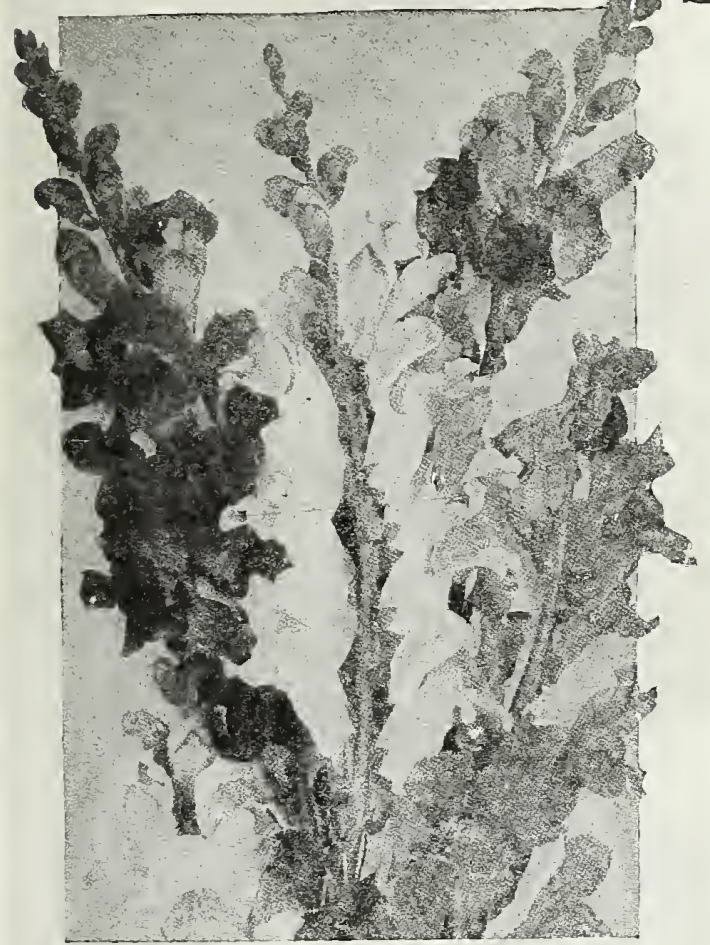

snapdragons

\section{Bermuda Grass} For Your Lawn

Excellent for making lawns as weli as pasture. Bermuda Grass in the South, like Fenturky Blue. Grass in tlie North, is one of the grasses for pasture, and yields good erops of hay on rich soil. It grows on nearly all soils, but succeeds best where land is fertile. Withstanding, as it does, the extremes of heat and drouth, it makes a thick interwoven sod and furnishes an abundance of leaves, and will stand the tramping of cattle and the extremes of heat and drouth better than any other grass we know. During the warm months, and especially the neated dry spells, there is nothing better. In the Soutb, it will stand indefinitely, and if plowed and harrosed in the spring once in thrce to five years the yield will be constantly kept up, especially if an appliration of fertilizer or stahle manure is given occasionally. To eladicate it the soil must be deeply plowed, the roots inverted to the sun in the hot, dry weatler for two or three weeks. It has been popularly supposed that a stand of Bermuda Grass cainot be obtained from seed, and planting by roots has been recommended and generally practiced throughout the South. This is wrong, as, if good seed is obtained, there is no trouble in getting a stand, and the cost of seeding in comparison to sodding is trifling. The seed should be sown in February, Marrh or April, at the rate of 8 to 10 pounds per acre. A rainy or damp day is best time to sow. Prepare the land well, getting it into as fine condition as possible, and make a good, firm secd-bed. As the seed is small, it should be iightly covered; a roller is preferable, or, if this cannot be obtained, use a brush harrow and cover the seed very lightly. Tbey wili iay dormant possibly thirty days in the ground untii proper time to germinate. It is now well known that there is much adulteration of Bermuda Grass, by mixing other seeds with them, that have the same appearance to the naked eye. There are many cases where purchasers thought tbey could not obtain a stand of this valuable grass, when, in fact, what they bad sown contained only a smali per cent of genuine Bermuda Grass. The seed we offer is perfectly pure, clean and ir $\mathrm{sb}$. Lb., $\$ 1.25 ; 3$ lbs. for $\$ 3.50 ; 10$ lbs. for $\$ 10.00$; postpaid, Write for prices in Iarger quantities.
SNAPDRAGONS (Antirrhinum)

Within the last few years Snapdragons have become immensely popular. This is not to be wondered at, as, whether used for cutting or for show in the garden, they are one of the most valuable flowers which can readily be grown from seed. We offer two distinct types, the large-flowering, tall-growing, or giant, and the equally large-flowered, half-dwarf variety. In our trials the seed sown out of doors the first week of May came into bloom early in July, remaining in full flower until November. For earlier flowering, they may be started indoors or in a frame in March, transplanting them to the open when the weather is suitable.

Tall Giant-Flowering

(No. 304), SCARIET.. \$0.10

(No.306), shell pink.... .10

(No. 307), milk white... .10

(No. 3C9), golden yellow .10

(No.312), MIXED ..... .10

TOM THUMB MIXED (No. 324), an extra dwarf strain, \$0.10

Giant Tall and Half-Dwarf Snapdragons (No. 379) Mixed

A Superior Mixture of both sorts, large pkt., 15c

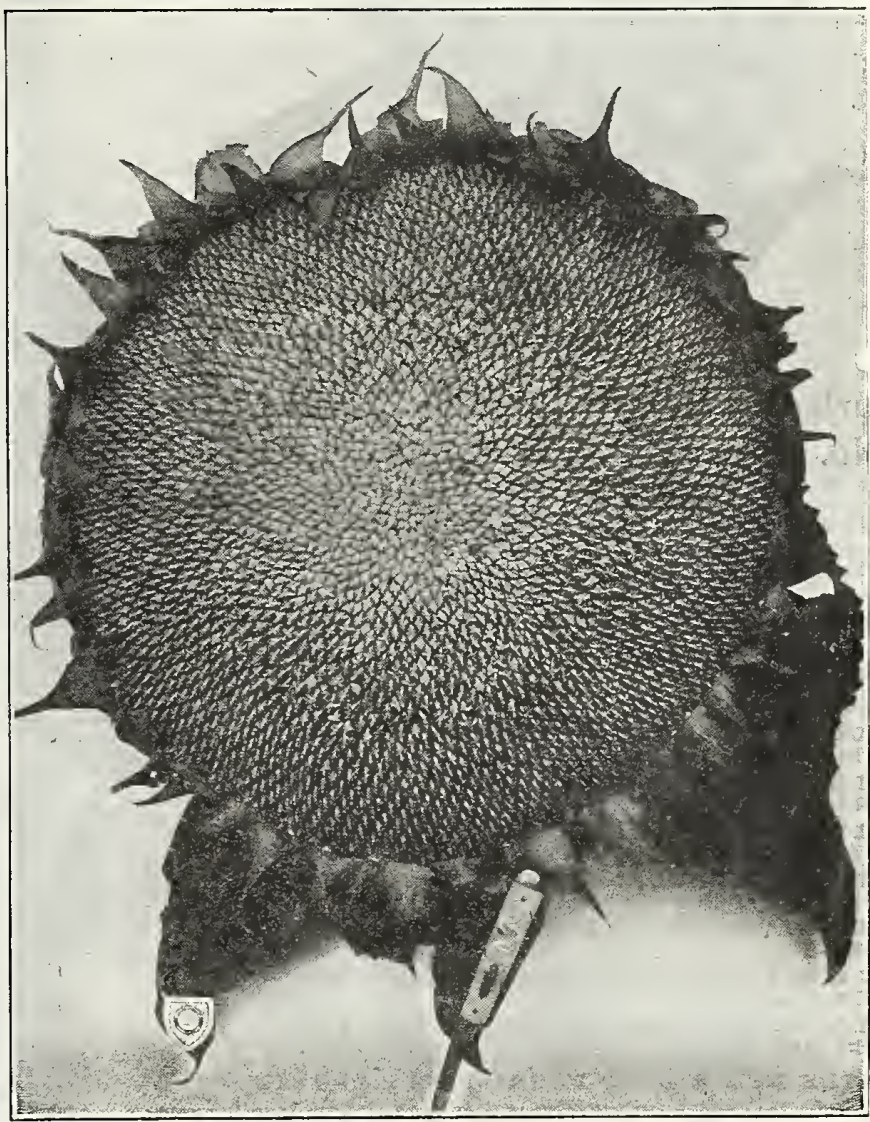

MAMMOTH SUNFLOWER

(No. 325)

If you have poultry, be sure to plant some Sunflowers, for they provide a most excellent feed and shade and can be grown easily and inexpensively. This variety produces the very largest heads, oftentimes measuring 15 to 20 inches across. The seeds are keenly relished by all kinds of poultry. A pound package will be all you will want to plant if you have a backyard poultry yard. About 3 pounds to plant an acre. Frice of seed, per ib., 35c. Write for our special prices on larger quantities. 


\section{Zinnias \\ (Youth and Old Age)}

All of Our Zinnia Seed Are Grown by a Zinnia Seed Specialist

The Zinnia is one of the most brilliant and showy of annuals, and has long been a general favorite. The seed can be sown in the hotbed or light window and transplanted, or sown later in the open 'ground. They come into flower early in the. summer and keep on blooming until hard frost.

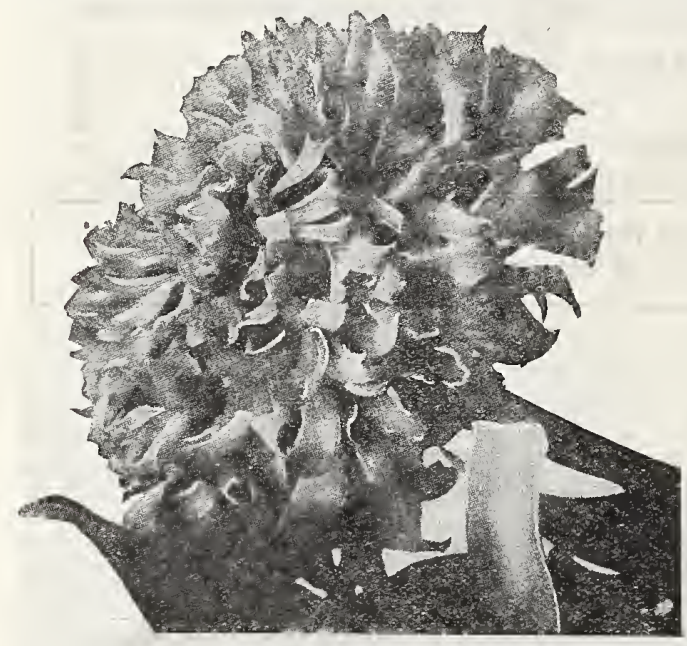

Curled and Crested Double Zinnia

\section{Curled and Crested Double Zinnia} (No. 326) A distinct and new variety of true from the seed. The petals are long, elegantly twisted and curled, giving the flower a most attractive, crested-like appearance, somewhat resembling a fine petaled Cactus Dahlia in shape. Prt. 10c.

Giant Double-Flowering This Zinnia ful improvement over the ordinary Doubleflowering for size of flow $\in \mathrm{r}$ and general vigor of the plant.

TALI GIANT DOUBLE, WHITE (NO, 327). Plit. 10c.

TALI GIANT DOUBLE, ROSE (NO. 328). Prt. 10c.

TALI GIANT DOUBIE, CRIMSON (NO. 329). Pkt. 10c.

TAIL GIANT DOUBLE, YELLOW (NO. 330). Pikt. 10c.

TALI GIANT DOUBLE, PURELE (NO. 331). Plrt. 10c.

TAIL GIANT DOUBIE, SCARLET (NO. 332). Plit. 10c.

TAII GIANT DOUBIE, VIOLET (NO. 333).

Pkt. 10c.

IITTIE RED RIDING FOOD ZINNIA (No. 334)-This is the baby of the Zinnia family, having very double, small bright scarlet blooms about an inch across. The plant grows from 8 to 10 inches in height. Pkt., $10 \mathrm{c}$.

\section{Elegans Double Flowered}

CANARY (No. 335)-Clear yellow. Pkt. 6c, 1/4 oz. 20c.

JACQUEMINOT (No. 336)-Rich crimson. Plt. 6c, 1/4 oz. 30c.

PINEST IMIXED (NO. 337)-All colors. Plt. 6c, oz, 50c. SCARIET (No. 338)-Bright and fiery. Pkt. 6c, 1/4 oz. 20c. WIITE (No. 339)-Pkt. 6c, 3/4 oz. $20 \mathrm{c}$.

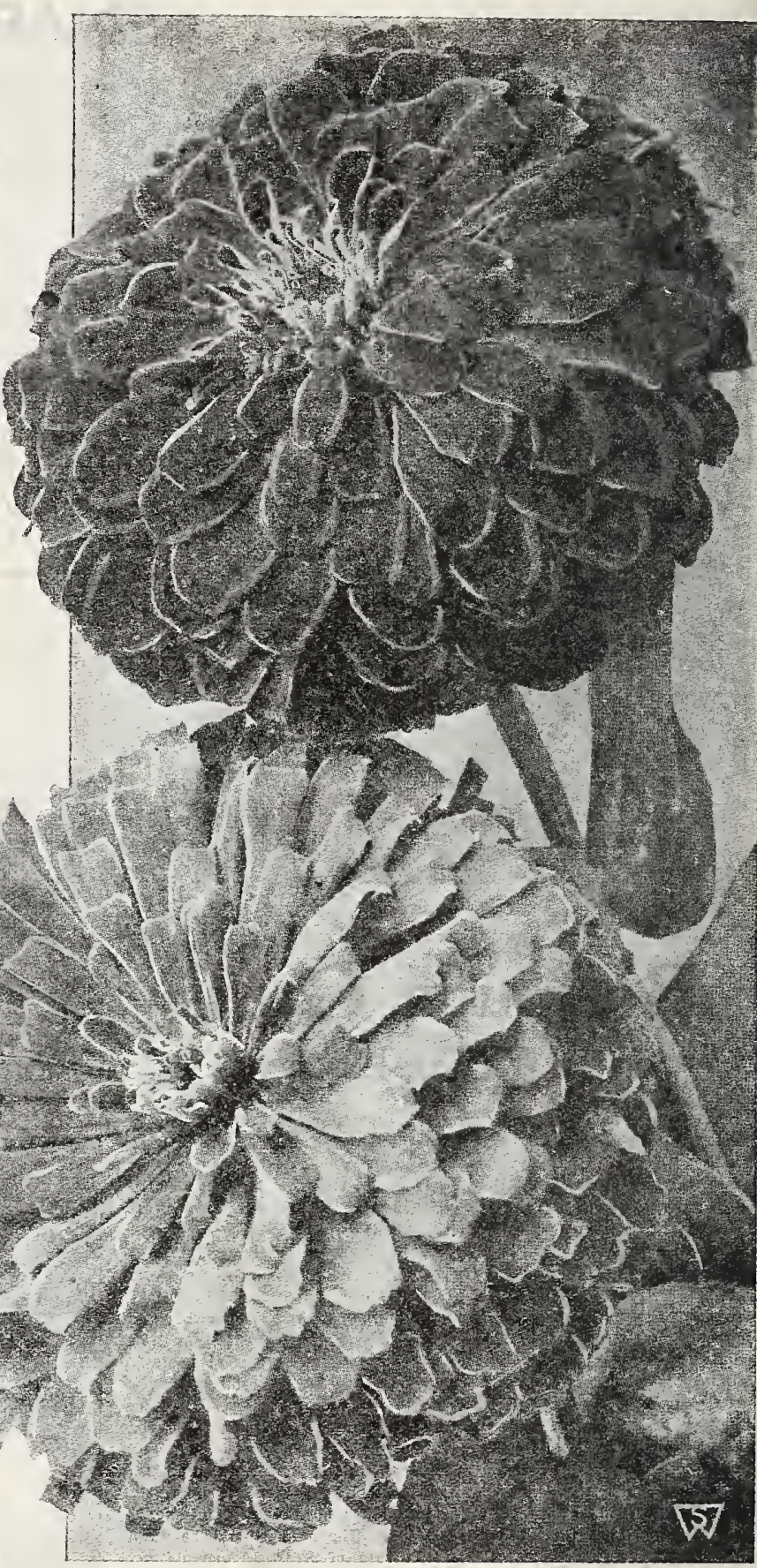

Giant Double Flowering Zinnias

\section{GIANT DOUBLE ZINNIAS MIXTURE \\ (No. 380)}

The seeds in this mixture were very carefully selected, and are noted for their wonderful range of color and monster blooms.

Iarge Pkt. 15c. 


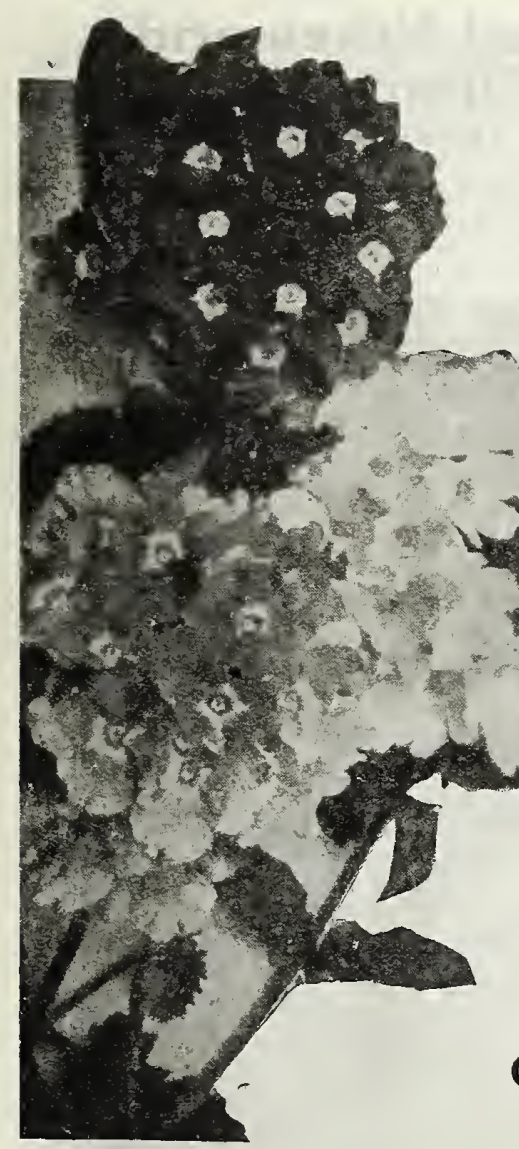

Verbena

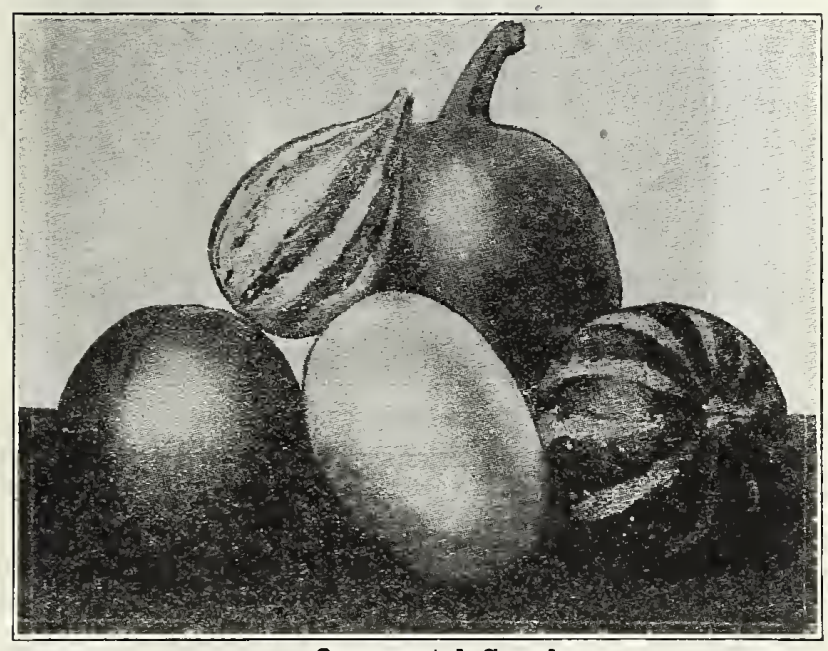

Ornamental Gourds

DIPPJR SFAPED (No. 355). Pkt. 6c.

NTST-JGG (N0. 356)-White egg-like fruits. Pkt. 6c.

IUFFA (No. 357)-The fibrous inside of fruit can be used as sponge or dish-rag. Pkt. $6 c$.

FrRCUIES CIUB (No. 358)-The green fruit grows from 2 to 5 feet long. Pkt. 6 c.

MUXID VARIETIES (No. 359)-Includes all the above gourds and many others. Pkt. 10c.

CATABASH GOUED (No. 360)-This is the variety from which Calabash Pipes are made. Prt. 10c.
Verbena Among the best known and most easily grown annuals, making an Mammoth Blue (No. 340)

Pkt.

Pkt.

White (No. 362) .........10

Mammoth Striped (No. 344). Many Irjmon VERBena (No. 345) (Aloysia Citriodora)-Every garden delightfuily scented foliage goes well with any flower, Prt. loc.

\section{Annual Vines and Climbers}

BAIIOON VINE (No. 350). (Iove-in-a-puff)-Rapid climber, with white flowers and attracti
insulated capsules. Pkt. 6c.

CIFMATIS PANICUIATA (No. 351). (Japanese Virgin's Bower)This is one of the best hardy climbers. The leaves are of a bright, glossy green, and when in bloom the plant is completely hidden beneath a blanket of white, hawthorn-scented blossoms; a grand plant for piazzas, fences; in fact, any position where a climber is want for the cemetery. Pkt. 10c, oz. 50c.

CANARY BIRD FIOWIR (No. 352)-Delicate foliage and yellow flowers. Pkt. 5c. CYPRISS VINE (No. 353)-Grows.15 to 20 feet tall. Delicate, fern-like foliag $\epsilon$ BAISAM APPIF (No. 354)-Grows 15 feet high. Ornamental foliage and curiously

Ornamental Gourds Rapidly growing, interesting plants, with ornamental

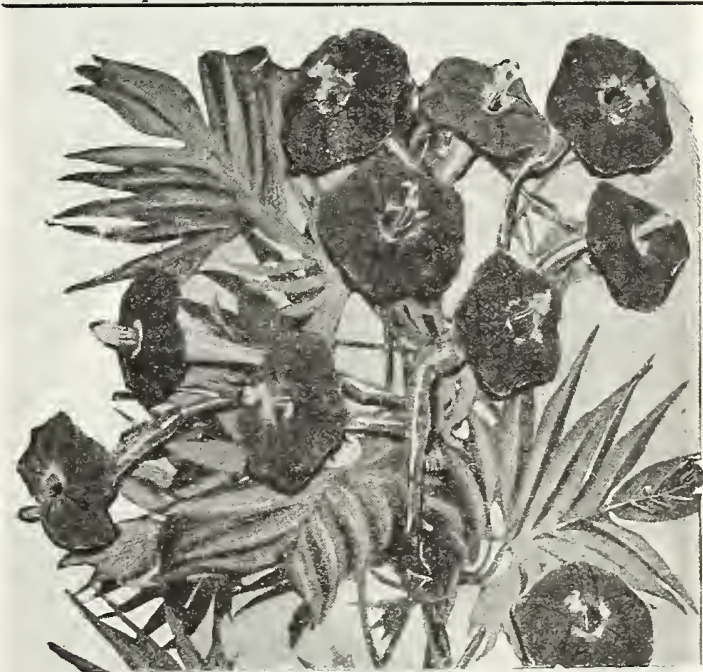

CARDINAI CIIMBER (No. 361)-The most brilliantly beautiful New Annual Climber that has been introduced for many a year. An extremely rapid grower, it flowers early and profusely; the vines branch freely, quickly attaining a height of from 20 to 30 feet. The dark green leaves are deeply lacinated, resembling a fine Japanese Maple; each plant bears almost countless numbers of extremely rich, circular, glowing scarlet flowers which average $1 \frac{1}{2}$ inches in diameter. It succeeds best in a warm, sunny position and should be planted in rich soil. While most profuse in flowering from July until frost, it is a shy seeder. We recommend starting early indoors. Plkt., $15 \mathrm{c}$. 


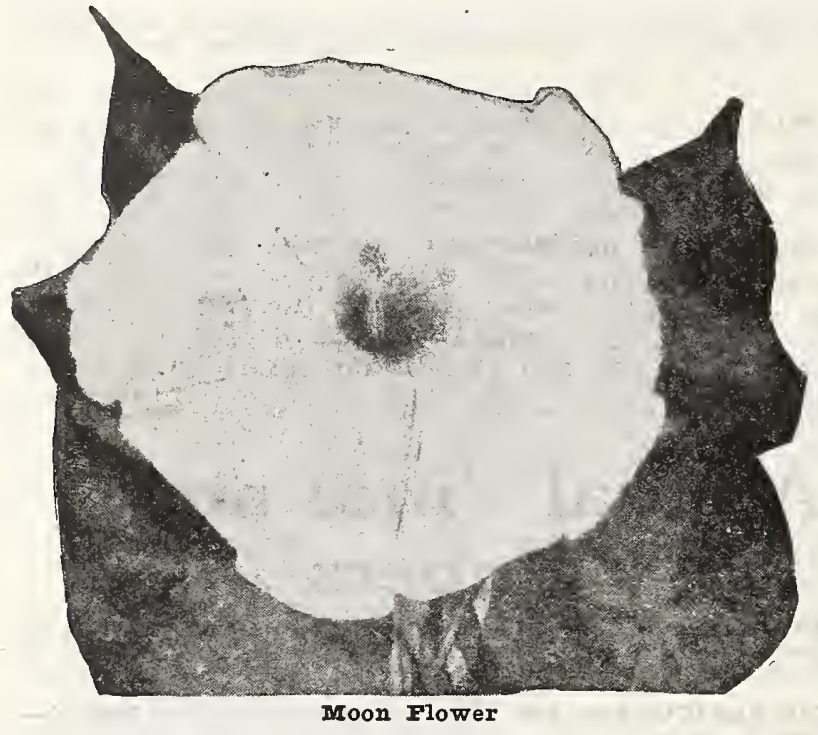

THUNBERGIA, MIXED (No, 364). (Black-Eyed Susan)Rapidly-growing annual, with beautiful foliage and pretty flowers. Pkt. 5c.

JACK BEAN OR DOIICIOS (No. 365). (Hyacinth Bean) - Easily grown annual, bearing a profusion of long spikes of pea-like blossoms. Pkt. 5c. oz. 20 c.

\section{VINES-All Sorts Mixed}

(No. 368)

This selection includes all the best and most popular varieties.

Plet. 10c

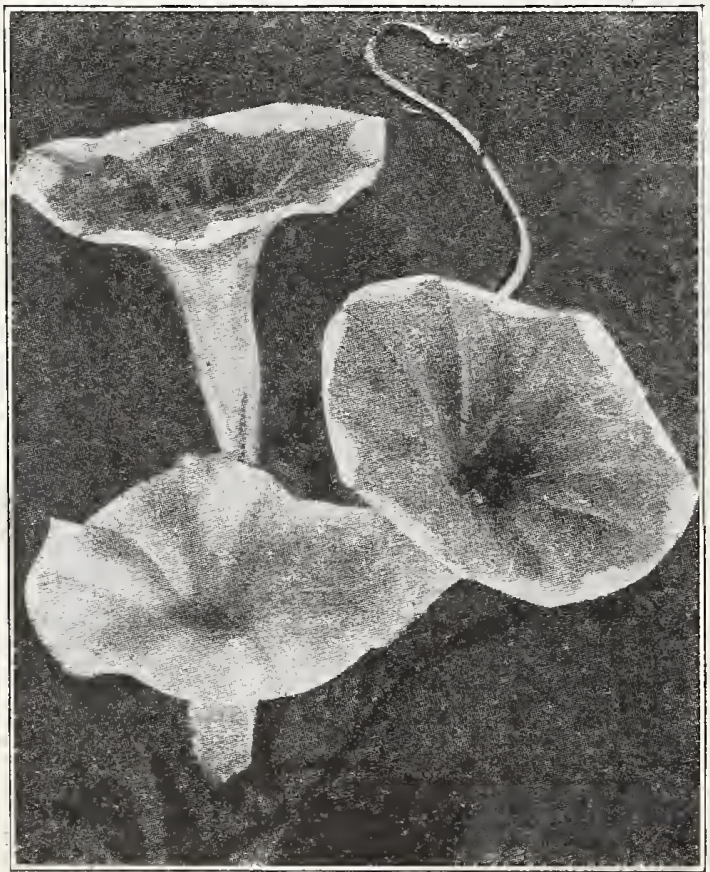

Japanese Morning Glory

MORNING GIORY, IMPERIAI JAPANESE MIXED (NO. 366)-Foliage green, flowers white, yellow and variegated. Colors range from soft rose to crimson, from daintiest blue to purple, from snow-white to gray. Plt. 10c, oz. 25c.

\section{Annual Vines and Climbers (Continued)}

MOON IIOWER, Iarge Flowering white (No. 363)-A most showy annual, with thousands of immense white flowers. A notch should always be filed in each seed, to break the hard coat, so the seed will germinate: Pkt. 10c.

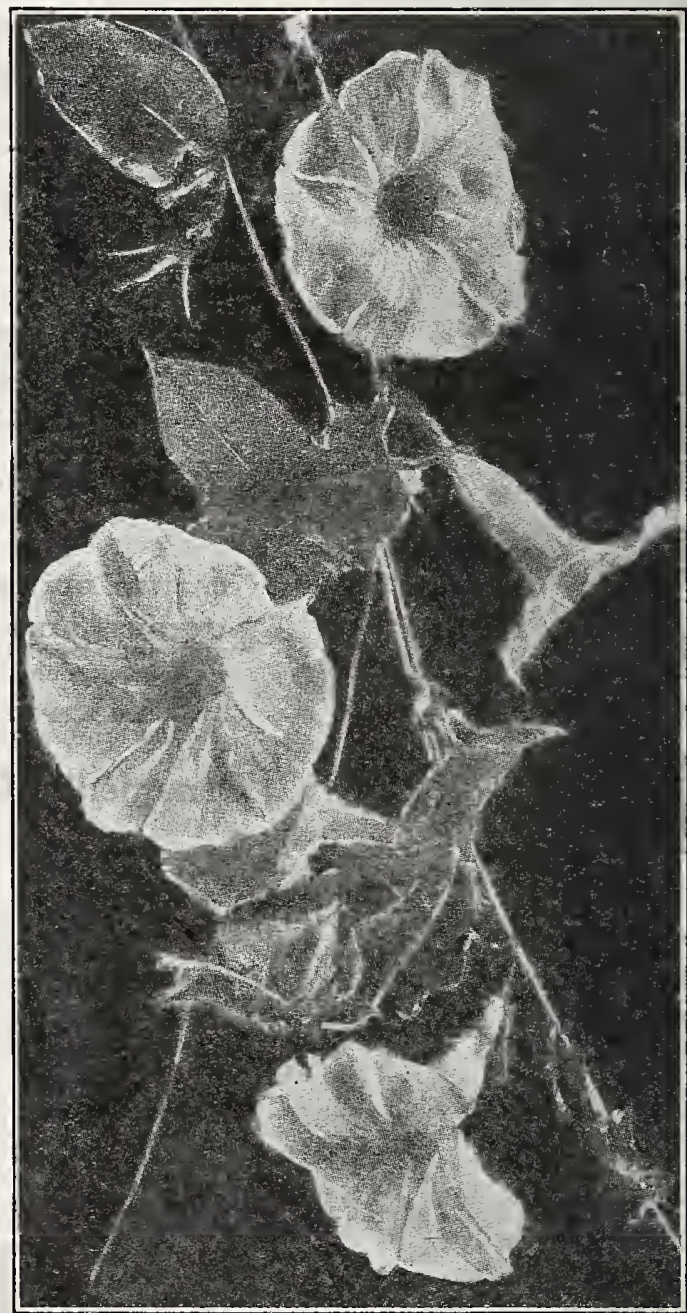

\section{Morning Glory}

MORNING GIORY, FINEST MIXED (No. 367)-This assortment contains a variety of colors of these old-fashioned flowers. Pkt. 5c, oz. 15c.

\section{Robinson Beauty Vine (Hardy) (No. 376)}

Illustrated in colors on outside back cover. Sometimes called Mountain Rose and Queen's Wreath.

This new climbing vine of striking and remarkable beauty comes to us from Central America, .. where.-it abounds and is said to color the mountains with a blaze of slowing pini. It is a strong, vigorous climber, suitable for covering walls, porches, verandas and fences. It has handsome foliage and is covered with splendid clusters of bright pink flowers during September and October, after all other climbers have ceased to give bloom. Packet of 15 seed for $25 \mathrm{c}$. 


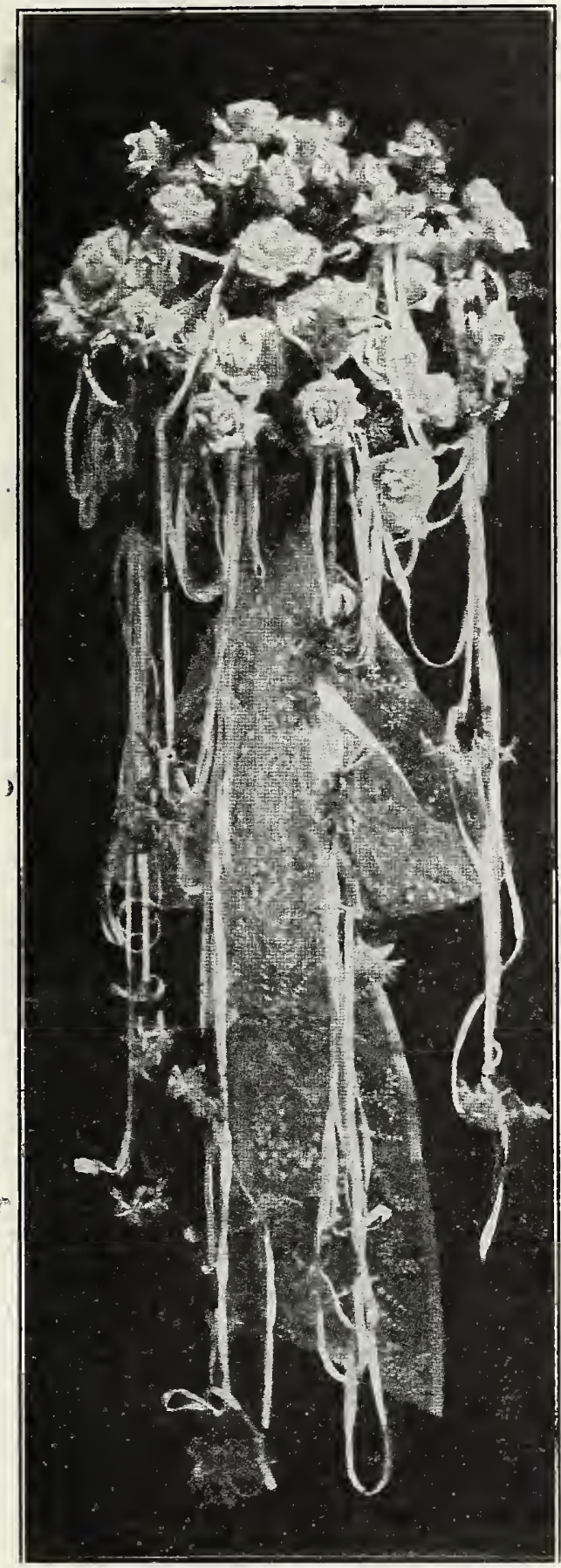

Bridal Bouquet with Shower

Bridal Bouquets, White Roses, \$3.00 up, with showers $\$ 5.00$ up.

Bridal Bouquets, White Carnations, $\$ 2.50$ up, with showers $\$ 4.00$ up.

Bridal Bouquets, Lilies of the Valley, $\$ 6.00$ up, with showers $\$ 8.00$ up.

Bridesmaids' Bouquets, $\$ 2.00$ up.

Corsage Bouquets, $\$ 2.50$ up.

Baskets for Flower Girls, $\$ 2.00$ up.

Ribbon extra.

\section{CUT FLOWERS}

FOR ALL OCCASIONS

\section{"Say It With Flowers"}

We grow immense quantities of beautiful flowers in our big greenhouses. In addition to our city business we malie shipments to all parts of Texas and adjoining states. Our stock is always complete and we can supply you with almost any quantity on short notice.

Remember your friends and relatives on Christmas, at Eastertide, Mother's Day, etc., with a beautiful box of flowers. If you know someone who is sick in one of the sanitariums of Dallas or nearby city, let us send them a cheery box of cut flowers and enclose your card.

Our wedding bouquets are unsurpassed for beauty and elegance. The flowers used are cut fresh right out of our greenhouses. The greatest of care is used in packing and shipping. In ordering wedding flowers it is best to order early.

We have experts who make up beautiful funeral designs. Phone or wire us for your needs in this line.

No matter what the occasion may be you can depend on us for good flowers and prompt service; however, we are not responsible for delays caused by parcel post or the express company.

It is out of the question to attempt to do any more than give you an idea of the prices which, of course, vary with the season.

When sending us orders direct always state exactly the amount you want to pay. You are sure to be more than satisfied with what we send. Fancy ferns are always included in every shipment without extra charge. We cannot accept shipping orders for less than $\$ 2.00$.

Cape Jasmines, May 10 to June $10 \ldots \ldots \ldots \ldots . \$ 0.50$ to $\$ 1.00$ per doz. American Beauty Roses, prices range in accord-

ance with the season, length of stem and 3.00 to 12.00 per aoz. per doz.

Roses, white or pink. $\$ 3.00$ to $\$ 6.00$ Roses, red ........ 3.00 to 8.00 Carnations ............ 1.75 to 3.50 Lilies of the Valley 1.00 to 1.50

Daffodils

Narcisisus ........\$1.00 to $\$ 1.50$

Easter Lilies ....... 3.00 to 6.00 Calla Lilies ........ 3.00 to 5.00

Sweet Peas, season, March to June, 25c per doz., \$1.50 per 100.

Sweet Peas in December, January and February, 35c per doz., $\$ 2.00$ per 100 .

Orchids, $\$ 18.00$ per doz.

Fern Strings, 4 to 6 feet long, $\$ 1.00$ each.

Single Violets, 25c per bunch.

Double Violets, 75c to $\$ 1.00$ per bunch.

Chrysanthemums. October, November, $\$ 3.00$ to $\$ 10.00$ per doz.

Cut Asparagus Sprays, 50c per doz.

Box of Assorted Flowers, $\$ 1.50$ to $\$ 10.00$ each.

Other cut flowers in season at market prices.

Where large quantities of cut flowers are wanted, we invite you to send us a list of your wants for prices.

\section{Funeral Designs}

\begin{tabular}{|c|c|c|c|}
\hline & Flats & Base & On Easel \\
\hline Anchor & $\$ 3.50$ up & $\$ 6.00$ up & $\$ 4.00 \mathrm{up}$ \\
\hline$\ldots \ldots \ldots \ldots \ldots \ldots \ldots$ & $3.00 \mathrm{up}$ & $5.00 \mathrm{up}$ & $3.50 \mathrm{up}$ \\
\hline Crescent $\ldots \ldots \ldots \ldots \ldots \ldots \ldots \ldots \ldots$ & 3.00 up & 5.00 up & 4.00 up \\
\hline$\ldots \ldots \ldots \ldots \ldots \ldots \ldots$ & 3.00 up & 5.00 up & 4.00.up \\
\hline 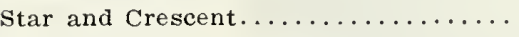 & & $6.00 \mathrm{up}$ & \\
\hline Gates Ajar & $10.00 \mathrm{np}$ & & \\
\hline Hearts $\ldots \ldots \ldots \ldots \ldots \ldots \ldots \ldots \ldots \ldots$ & 3.00 up & 5.00 up & $4.00 \mathrm{up}$ \\
\hline $\operatorname{Harp} \ldots \ldots \ldots \ldots \ldots \ldots \ldots \ldots \ldots \ldots \ldots \ldots \ldots$ & $3.50 \mathrm{up}$ & 5.00 up & $4.00 \mathrm{up}$ \\
\hline Lyre $\ldots \ldots \ldots \ldots \ldots \ldots \ldots \ldots \ldots \ldots \ldots$ & 3.00 up & 5.00 up & 4.00 up \\
\hline 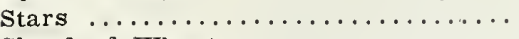 & $3.00 \mathrm{up}$ & 5.00 up & $4.00 \mathrm{up}$ \\
\hline 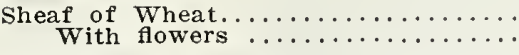 & & เ๘. & $\begin{array}{l}1.00 \text { up } \\
2.50 \text { up }\end{array}$ \\
\hline $\begin{array}{l}\text { Plllows } \ldots \ldots \ldots \ldots \ldots \ldots \ldots \ldots \ldots \ldots \ldots \\
\text { Lodge Designs-Masonic, Odd Fello }\end{array}$ & $\mathrm{El}$ & & $\begin{array}{l}3.50 \text { up } \\
5.00 \text { up }\end{array}$ \\
\hline
\end{tabular}




\section{Flowering Plants for House and Garden}

\section{SEE PAGE 1 BEFORE YOU ORDER}

A great many people prefer flower plants to flower seed. If you could glance into our greenhouses at this time of year, you would see flower plants of every kind growing. Growing these plants in such enormous quar:tities enables us to make low prices. Not only will you be pleased with our plants, but also you will be pleased with the manner in which the plants you order are packed for shipment.

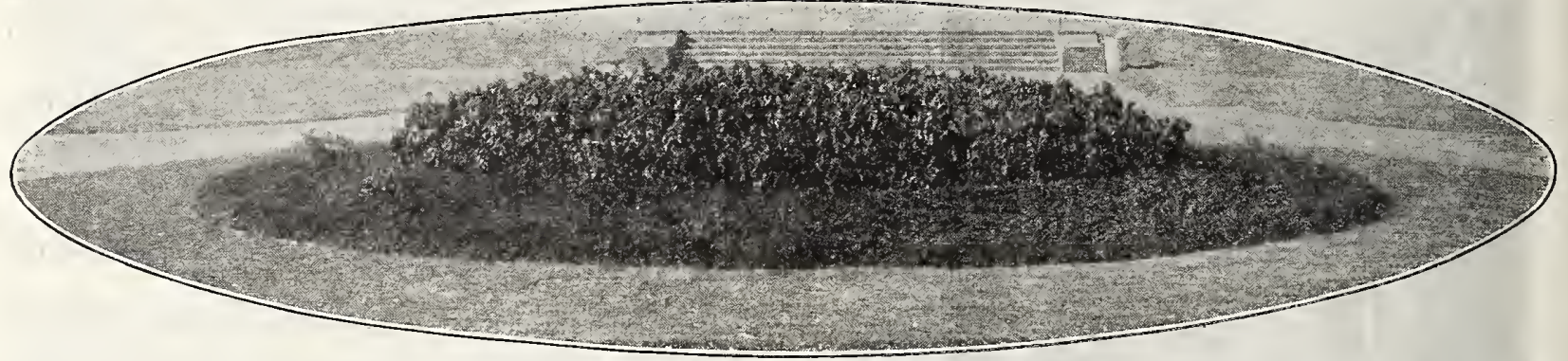

Bed of Acalyha Bordered with Altermanthera

Alternanthera or (Border Plant) An admirable dwarf foliage plant of compact growth. Grows 6 inches high. Extensively used in parks for lettering and flower bed designs. 3 for $25 \mathrm{c}, 65 \mathrm{c}$ per doz., $\$ 5.00$ per hundred.

Asters Flowers are extra large petals, similar to Japanese Chrysanthemum. Plants attain a height of $21 / 2$ ft.; branching habit and long stems. Colors-Red, white, pink and blue. Price, $15 \mathrm{c}$ each, 3 for $40 \mathrm{c}$, doz. for $\$ 1.50$.

Sweet Alyssum pretty little beds, vases, baskets, edging or rockwork, blooming profusely all summer; useful also for winter flowering, Very swettly scented. Price $15 \mathrm{c}$ each, 3 for $40 \mathrm{c}$.

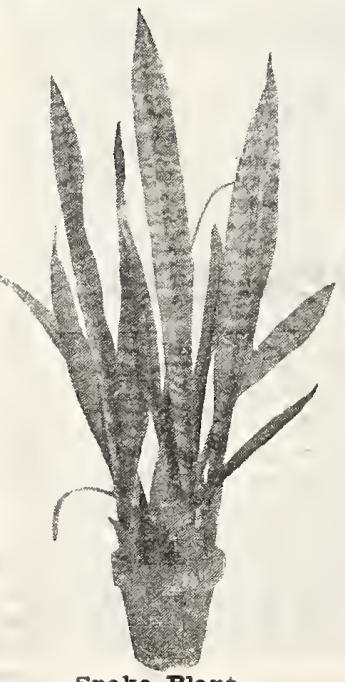

Snake Plant

SEE SPECIAI OFFER Page 38

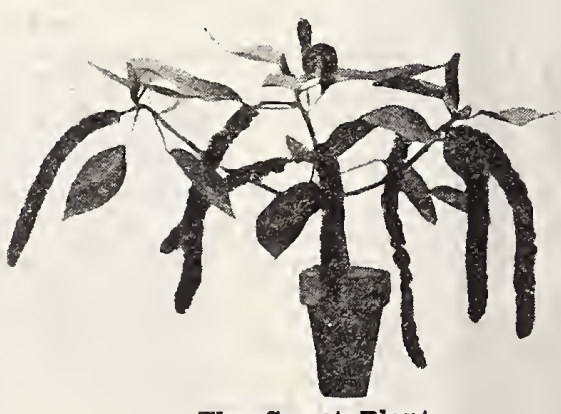

The Comet Plant
Sanseviera Snake Plant-A new decorative plant of great value. There is scarcely a decorative plant listed that is more striking in foliage and habit than this, and certainly none other stands as much downright neglect and hardship as this. Nothing but frost or continued drenching with water has terrors for it. It will stand gas and dust, and will go for months without a drop of water, yet remain as thrifty as ever. Singularly beautiful, as well as easily grown. Price, large plants, 28c each; 3 for $75 \mathrm{c} ; \$ 2.75$ per doz.

Umbrella Plant A splendid aquatic plant, three feet high, surmounted at the top with a whorl of leaves. An excellent plant for growing in water or damp places, thriving in any good soil and always presenting a fresh, green, attractive appearance. Excellent for porch boxes and house plants. Price, 15c each, 3 for $40 \mathrm{c}$; large plants 25c each.

\section{The Comet Plant} Chenille Plant or Sanderi

Foliage deep, glossy green, flowers bright red, rope-ilke pendants drooping from the axil of each leaf, often 18 to 20 inches long. Makes splendid growth when planted outside in summer, and if grown in pots should be repotted frequently to promote vigorous growth. Be careful in watering not to wet flowers and they will remain perfect much longer. 25c each, 3 for $65 \mathrm{c}$, prepaid.

Santolina A very pretty dwarf Santolina growing little plant. The foliage is finely cut and of a silver gray color, thus making it particularly useful and valuable for edgings and ribbon beds, as it contrasts finely with plants of darker color or larger leaves, like Coleus. $10 \mathrm{c}$ each, 3 for $25 \mathrm{c}, 65 \mathrm{c}$ per doz.

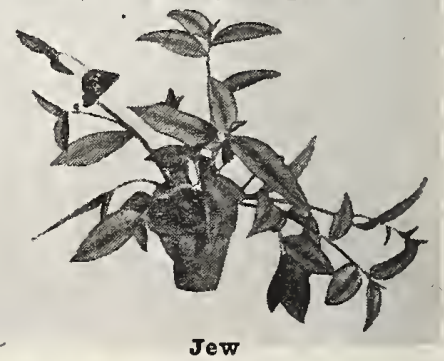

Wandering Jew Tradescantia A variegated plant of easy and rapid growth: foliage most beautiful, variegated purple, scarlet, yellow and white, and producing small white flowers. Very easily propagated by cuttings of pieces of shoots. Plants cuttings of pieces of shoots. Plants should have plenty of moisture to
grow vigorously. The plant is usually used in connection with hanging baskets, porch box $\in \mathbb{S}$, etc. Price, $10 \mathrm{c}$ each; 3 for $25 \mathrm{c}$; $\$ 1.75$ por des. postpaid. 


\section{Beautiful Begonias}

Few plants can be grown so readily and produce such a profusion and brilliancy of foliage and flowers as Begonias.

Rubra This Begonia is still a great favorite. The flowers clusters. These, combined with the rich green foliage, make it one of the best plants for house culture. Price, 26c each; 3 for $75 \mathrm{c}$.

Erfordia $W \epsilon$ can recommend this variety as being one Ere of the very best. It grows in symmetrical, comwact form, with shining green follage, continua, 22c each; 3 for $63 \mathrm{c}$.

Alba Picta tong, pointed, slender leaves, thickly spot elegant white flowers in clusters. Price, $22 \mathrm{c}$ each; 3 for $63 \mathrm{c}$. Argentea Guttata Has the silvery blotches of Alba Ariety Beautifu and in grace is not equalcd silver markings: white flowers in clusters on end of great stems. Price, 22c each; 3 for $63 \mathrm{c}$.

President Carnot A very strong growing variety of iff, upright habit, foliage large, similar in style to Begonia Rubra, but more than twice as large; upper side deep green, under side purplish red. Flowers beau3 for $70 \mathrm{c}$.

Gracilis Luminosa $\begin{aligned} & \text { The newest Begonia; rich, glossy, } \\ & \text { green, often shaded deep bronze. }\end{aligned}$ The flowers, when first opening, are bright cherry, changing to a clear coral red. Price, $25 \mathrm{c}$ each; 3 for $70 \mathrm{c}$.

\section{MINT}

Used for flavoring Ice Tea, 10c each; 3 for $25 \mathrm{c}$

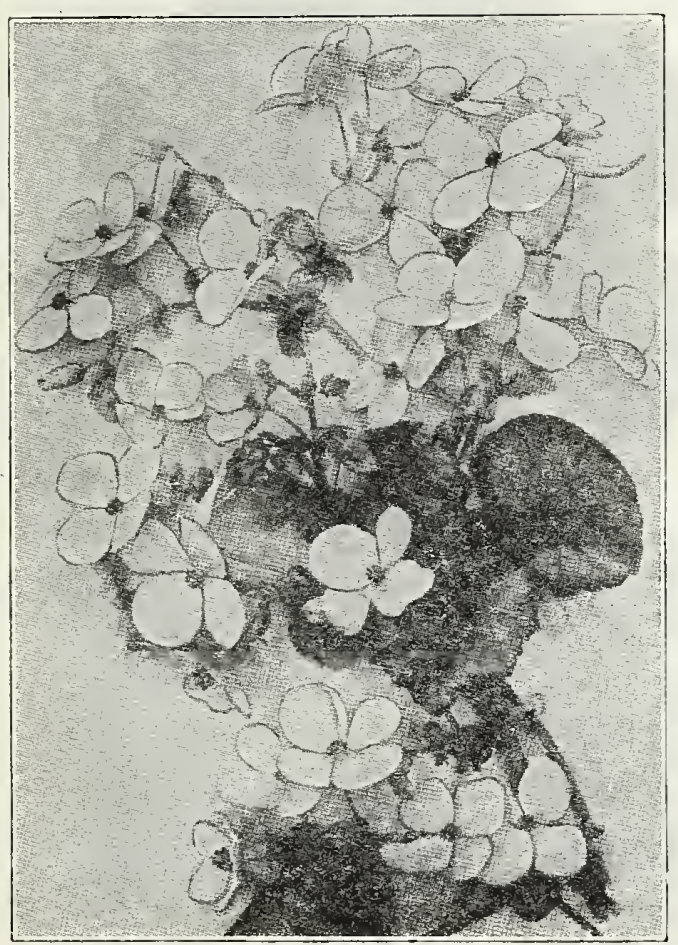

Gracilis Iuminosa Begonia

\section{Jasmines}

Cestrum Nocturnum (Night-Blooming $\begin{gathered}\text { Jasmine)- } \\ \text { Free blooming }\end{gathered}$ fragrant at night. Price, 35c each.

Revolution (Yellow Jasmine)-A strong climbing plant, fragrant blossoms.

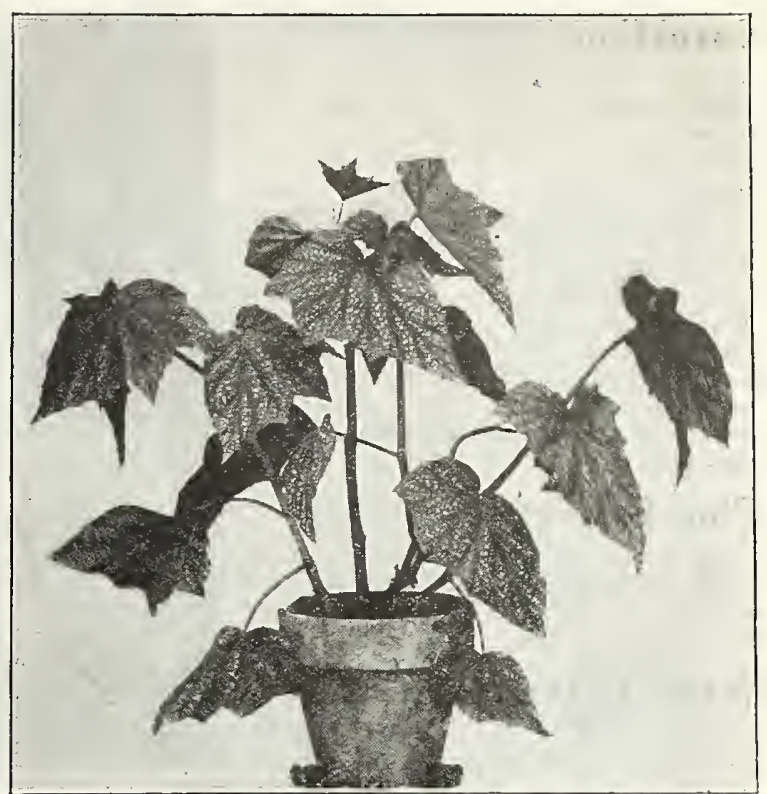

II de Iesseps Begonia

Md de Lesseps A remarkably strong growing variety, and somewhat in style of Begonia Rubra, but more than twice as large; upper side deep green, under side purplish-red, flowers pure white, in large pendant panicles. Price, 25c each; 3 for $70 \mathrm{c}$.

Snapdragons (Antirrhinum) The snapdragons do country the attention they deserve. Tourists see them used in beds and borders in all of the famous parks and in the old World, and we know from actual tests that they do just as well here as in Europe. They succeed best in rather light soil, in a sunny position, and, although perennials, succeed well when treated as annuals. Fine for cutting. Assorted colors, 15c each; 3 for 40c; $\$ 1.50$ per doz.

NO GARDEN

IS COMPLETE

WITHOUT

OUR OLD

FASHIONED

GARDEN

COLLECTION

See Page 6

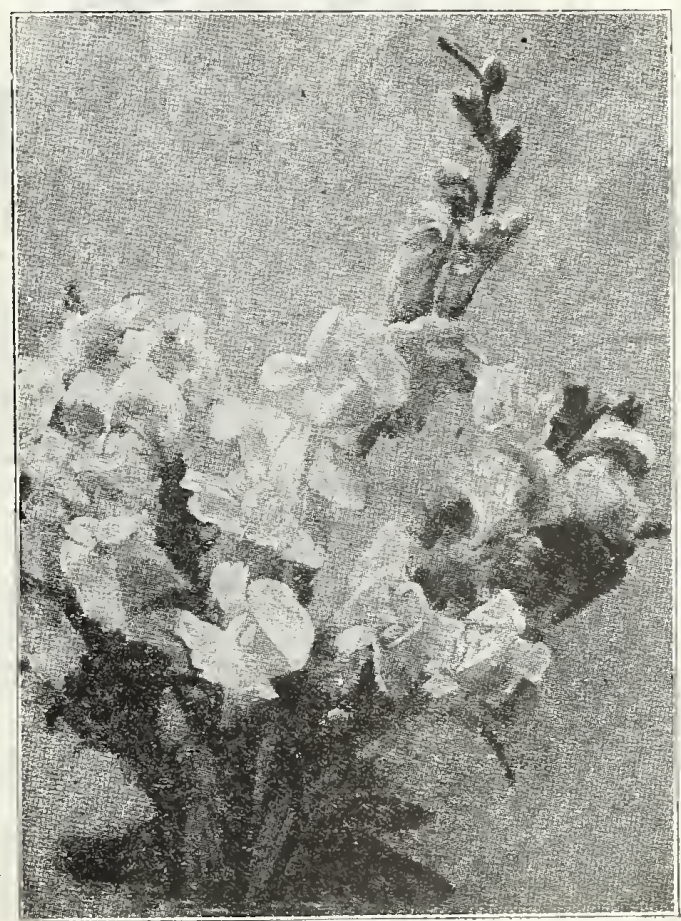

Snapdragon 

Carnation The delicately rich and nection with the beautiful colors and perfect outline of the Carnation secures for it a prominent place in all collections of plants either for the house or garden. It is one of the sweetest of flowers and yields abundance of blooms all summer. The plants may be potted in October, watered and shaded a few days, and they will go right along blooming all winter, in a bright, sunny window. Our list embraces a large variety of colors and is the cream of the standard varieties. Price, 20c each; 3 for 55c; \$2.co per doz.

Pink Enchantress One of the recently introduced Carnations, a leader in its color, an exquisitely delicate shade of shell-pink, deepening toward the center.

White Enchantress one of the yet produced, of pure quality, large size and immense production.

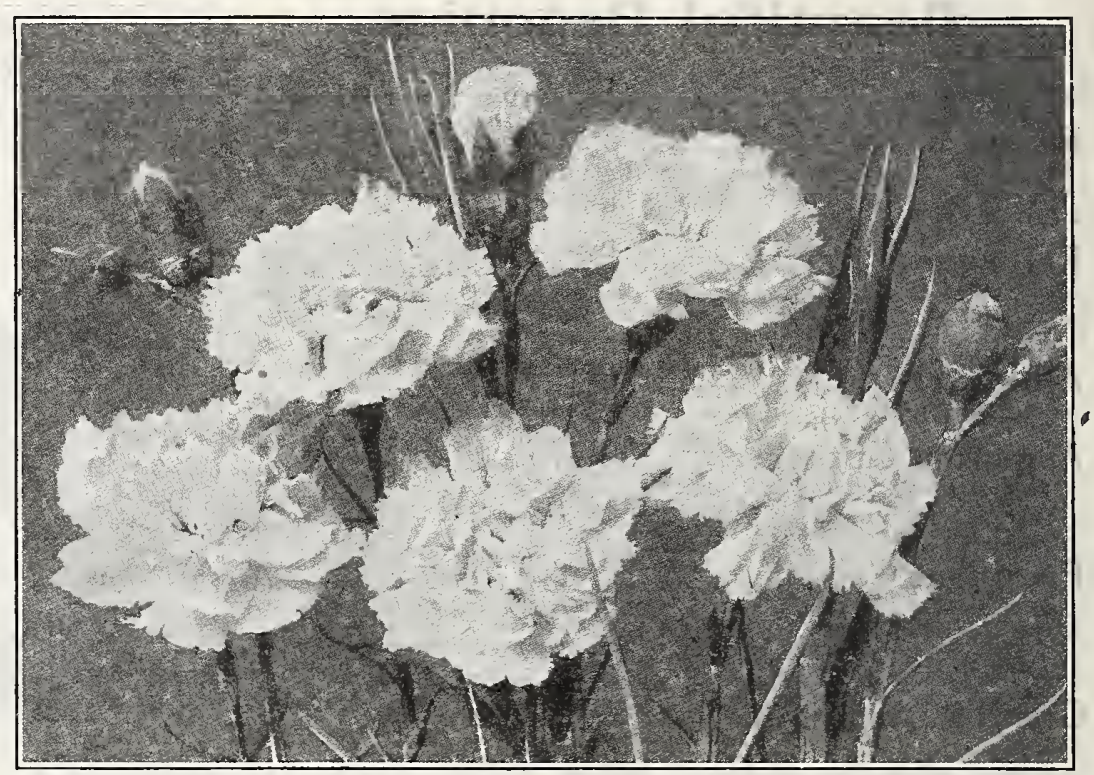

\section{Rose Pink Enchantress A lovely rose-pink shade}

Pink Enchantress old favorite "Enchantress."

Mrs. C. W. Ward Perfect form, full center color, cent variety of the largest size, free blooming and keeps splendidly.

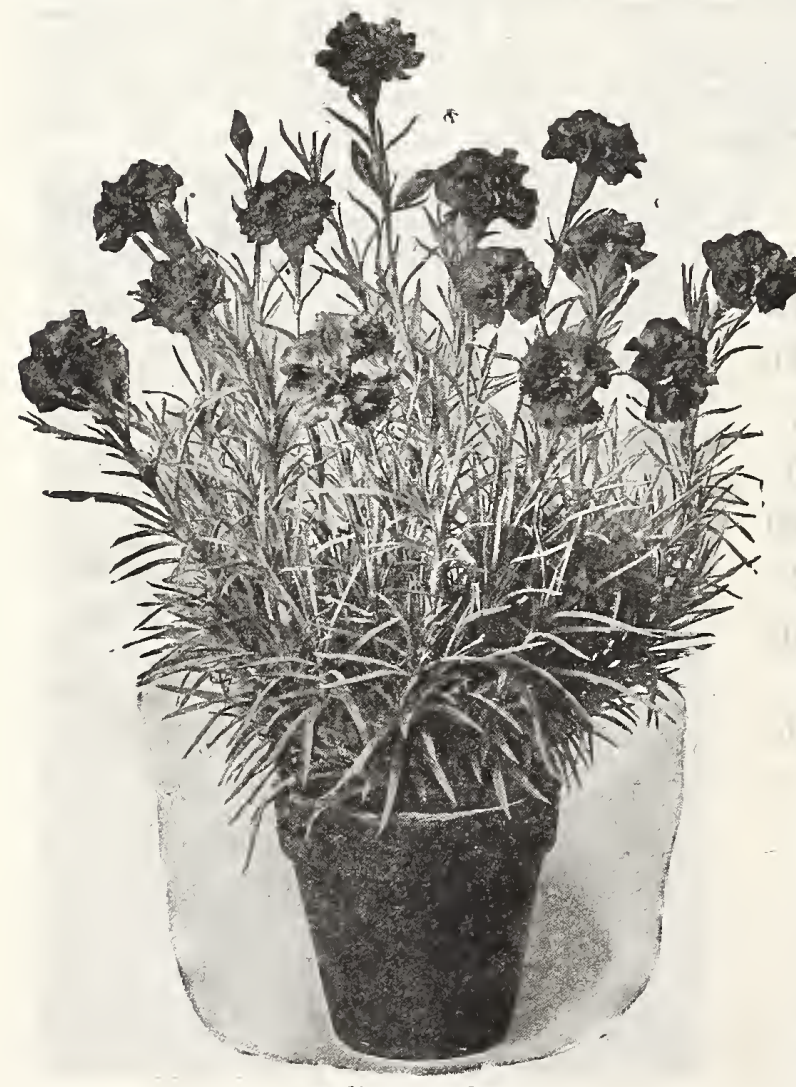

\section{Belle Washburn}

Brilliant red. Flowers $3 \frac{1}{2}$ to 4 inches across. Continuous bloomer.

Matchless This fine variety is well named, and well deserves the popularity that it has won; exhibition size and quality.

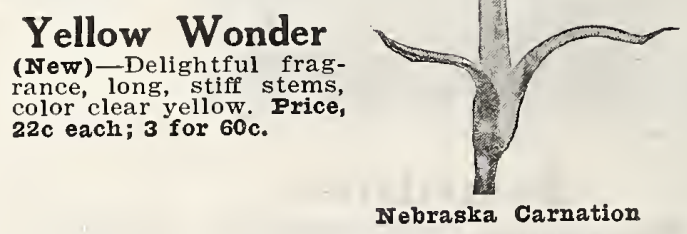

Nebraska (New)-It is bright scarlet; makes long stems early and and good sizable plants. It comes into fiower of the best of its color. 


\section{Our "Sun-Proof" Offers}

All Offers on This Page Consist of Plants Best Adapted to the South's Hot, Dry
Summers

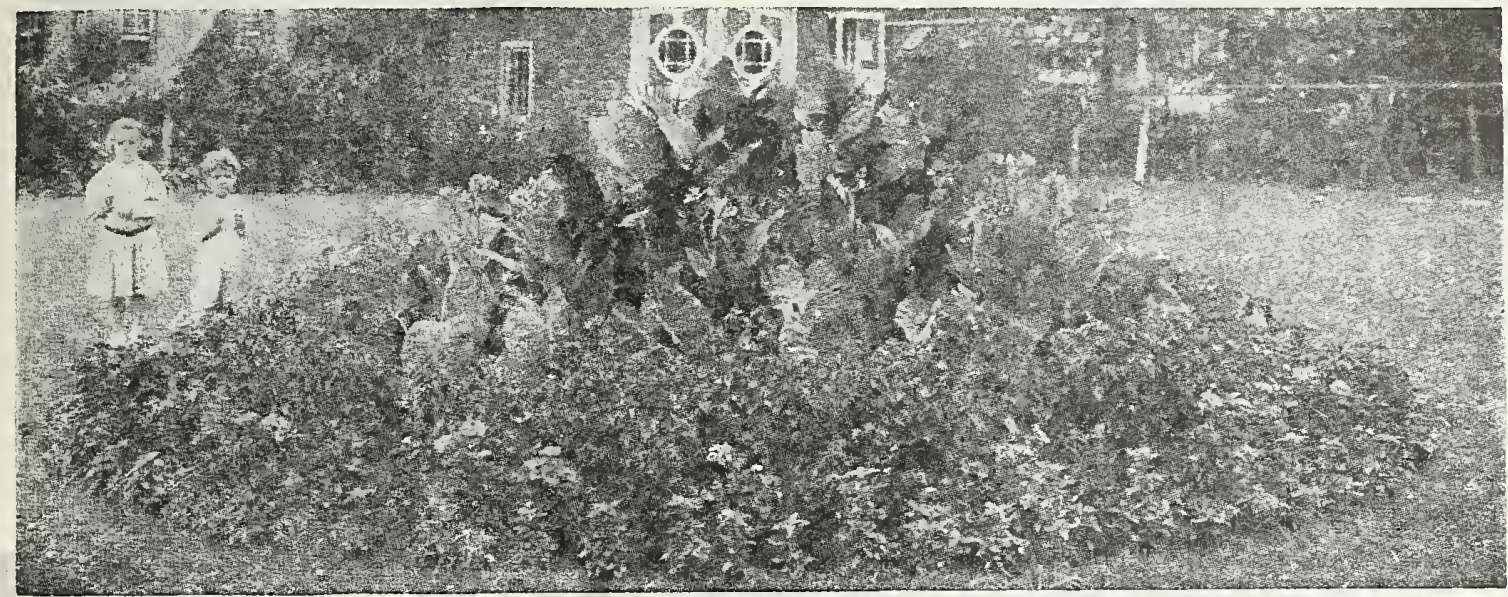

Sun-Proof Offer (No. 1) Above illustration represents a bed 10 feet in diameter and if planted as follows will apart in the circles and the circles one foot apart in the bed. The outer circle would require 30 violets, the next inner circle 24 Daisies, next smaller circle 18 Salvias, next circle 12 Caladiums (Elephant's Ear), and the center 10 Cannas. 94 plants, by express, purchaser paying charges for \$\$.73.

\section{Dazzling Salvias, 12 for $\$ 1.19$}

Sun-Proof Offer (No. 2) They grow in b ush one-half feet high. The foliage is dense, forming a mound of vivid green surrounded by blazing red flower's. Collections are estimated on planting 12 inches apart in rows and rows 12 inches apart.

3 ft. (Diam.) Bed, 12 plants............\$1.19 prepaid

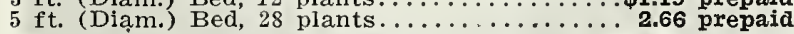

\section{Splendid Single Petunias, 12 for $84 \mathrm{c}$} Sun-Proof Offer (No. 3) $\begin{aligned} & \text { We offer here an un- } \\ & \text { usual mixture of beau- }\end{aligned}$ tiful colors. For outdoor decorations there are few plants that excel the single petunia. They commence blooming when quite small and when at their best display a gorgeous offect of flower and foliage. Collections are estimated on planting 12 inches apart in rows and rows 12 inches a part

3 ft. (Diam.) Bed, 12 plants............ 87c prepaid 5 ft. (Diam.) Bed, 28 plants ................96 prepaid

\section{Mammoth Verbenas, 12 for $\$ 1.08$}

Sun-Proof Offer (No. 4) The verbena is one of ding plants, blooms freely and constantly. Colors are many. Collections are estimated on planting 12 inches apart in rows and rows 12 inches apart.

3 ft. (Diam.) Bed, 12 plants...........\$1.08 prepaid 5 ft. (Diam.) Bed, 28 plants................. 28 prepaid

\section{Blazing Lantanas, 6 for $72 \mathrm{c}$}

Sun-Proof Offer (No. 5 ) These gorgeous bedding ing in favor. Their exquisite colorings in many of the improved varieties are remarkable. The fiowers embrace all shacies of coloring. Collection is estimated on planting 2 feet apart in rows and rows 2 feet apart.

$3 \mathrm{ft.}$ (Diam.) Bed, 6 plants..................72c $5 \mathrm{ft}$ (Diam.) Bed, 14 plants....................

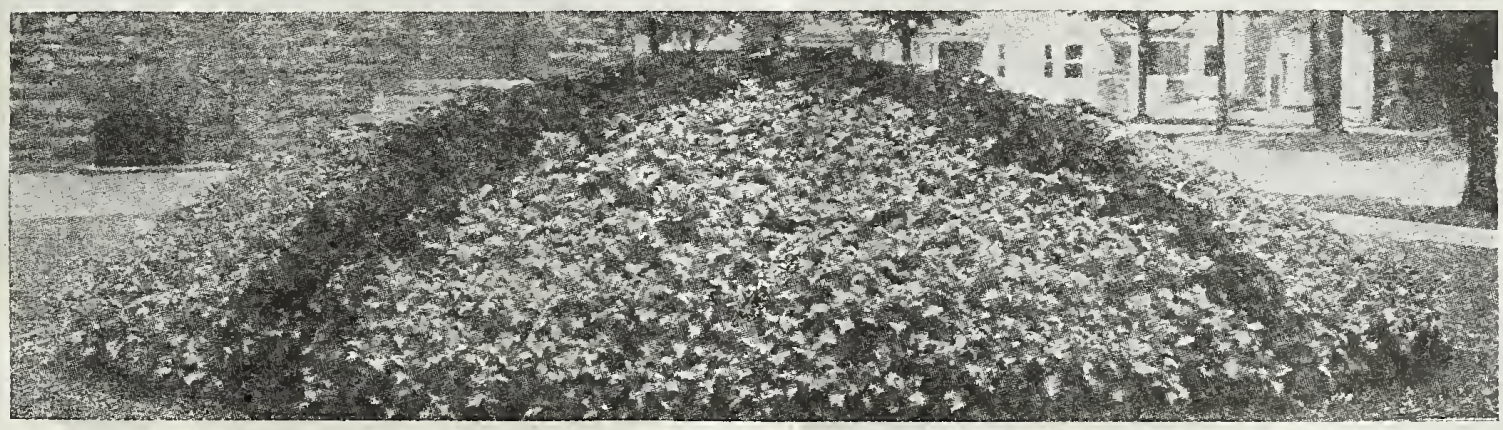

\section{Brilliant Foliage Planting}

\section{Gorgeous Coleus}

Sun-Proof Offer (No. 6) Coleus are acknowledged the standard bedding plant. A bed 4 feet in diameter would require 95 plants. Price $\$ 6.24$. These two collections by express. only. Purchaser paying express charges. 


\section{Chrysanthemums}

Who does not admire the "Queen of Autumn," the handsomest of all autumnal flowers? Nearly all the varieties will grow and bloom in open ground before severe weather sets in. We grow none but the most desirable varieties.

Our chrysanthemums are the most beautiful and best adapted to our southern climate.

In order to grow large, full blooms, leave very few buds on a plant, not more than one to each branch and in case of growing individual flowers for exhibition, it is best to disbud the plant entirely with the exception of one flower to be produced. Bone meal and liquid manure are both fine fertilizers to be used in moderation so as not to burn the foliage. Chrysanthemums should have a very rich soil and a sunny location. Give plenty of water from the time the buds first appear until they are in full bloom. The plants should be pinched back while growing to give them good shape. Price, $18 \mathrm{c}$ each; 3 for $52 \mathrm{c}$; doz., $\$ 2.00$, all prepaid.

White Turner of enormous size. This variety stands at the head of all White varieties.

Odessa An enormous bright yellow. Grand in to White Turner.

Smith's Sensation (Nrw) A beatiful, soft growth, with foliage carried well up to the flower. Mrs. Weeks very large, pure White, with im-

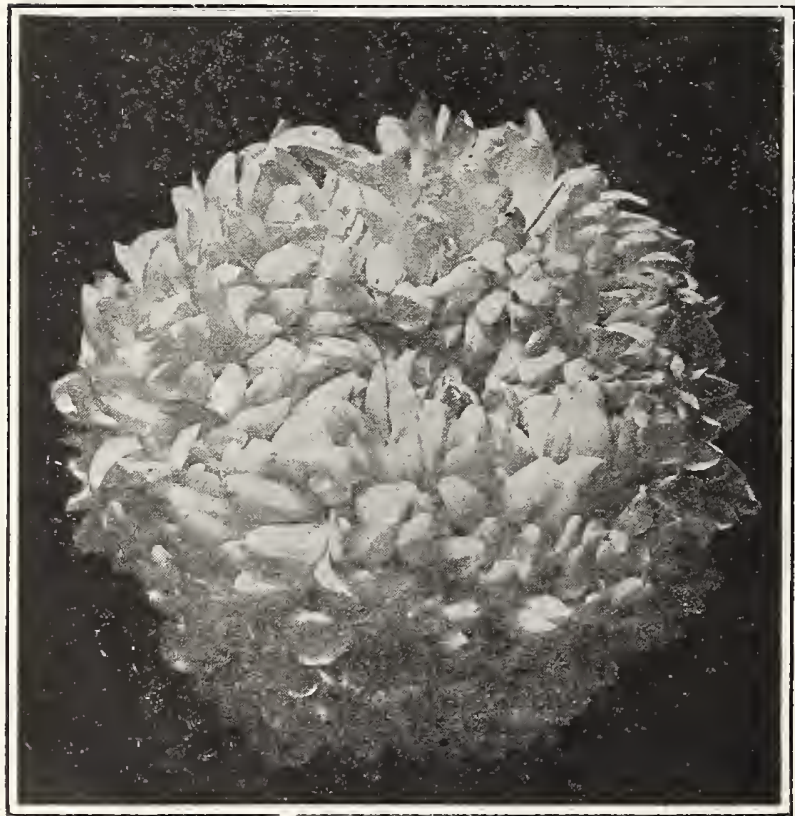




\section{Chrysanthemums-(Continued)}

Price, 18c each; 3 for 52 ; doz., $\$ 2.00$; all prepaid.

Black Hawk The largest and most beautiful dark crimson-scarlet yet much desired in Chrysanthemums; flowers of immense size on fine, stiff stems.

Marigold (NEw) Brighter than Golden Wedding, 9 inches in diamequal it in color, size. Major Bonnaffon This splendid Yellow commercial is still grown

O. H. Kahn (NEw) A beautiful Strong upright growth; 4 feet high.

Harvard (NEw) Japanese reflexed; Golden Soloman (NEW) A very Considered one of the finest yellow varieties ever introduced.

Golden Queen (NEW) A commering October 1 to 10 . Fine, incurved form and fully double from either early or late buds; 6 inches in diameter; $61 / 2$ feet high; good stem and foliage.

White Helen Frick Those who the late pink variety, Helen Frick, will be pleased to know a white sport has been established. In the early stage of development they show some trace of light pink, but when mature are pure white.

Dr. Enguehard Color deep, clear pink, much Dr. Enguehard darker shade than any other ones drooping as the center opens.

Col. D. Appleton A very large, deep golden ing flower of fine finish and form.

Golden Glow Bright yellow, of velvety finFlower $5 \frac{1}{2}$ inches in diameter; the very earliest yellow.

October Frost (NEW) A very early White. flowers, perfect in form

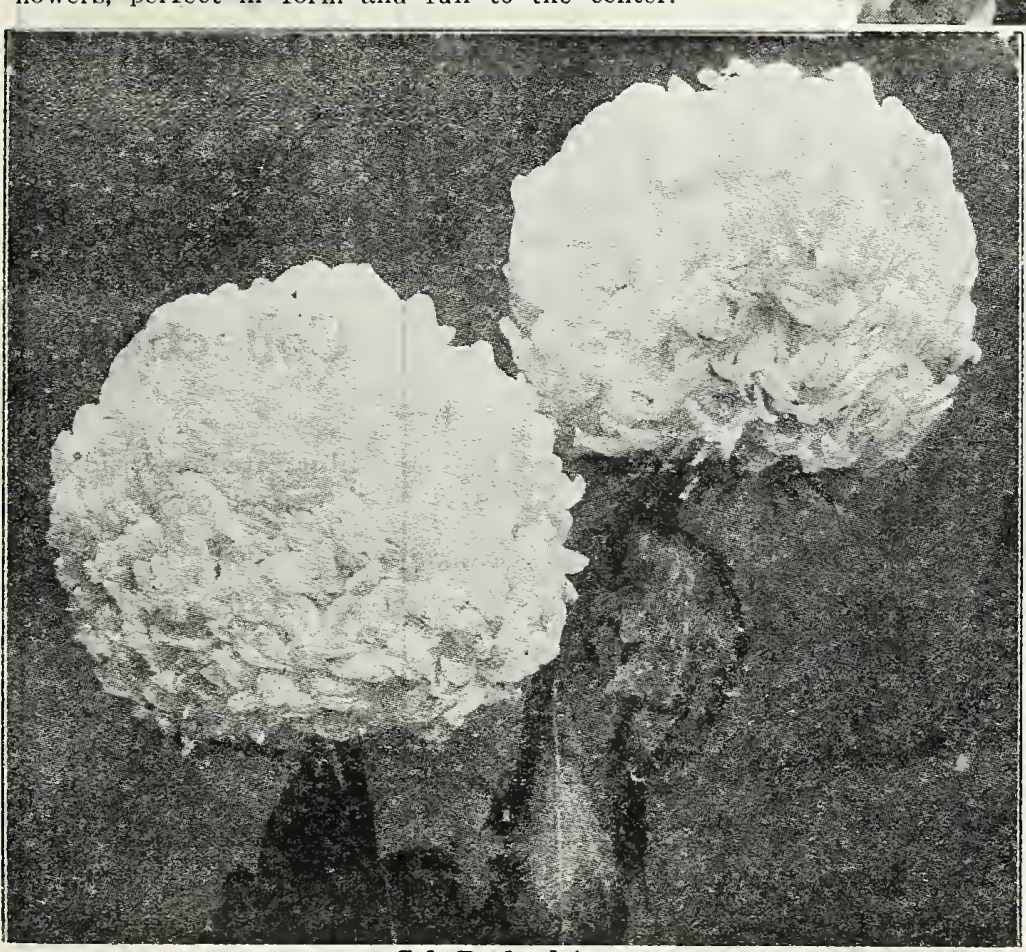

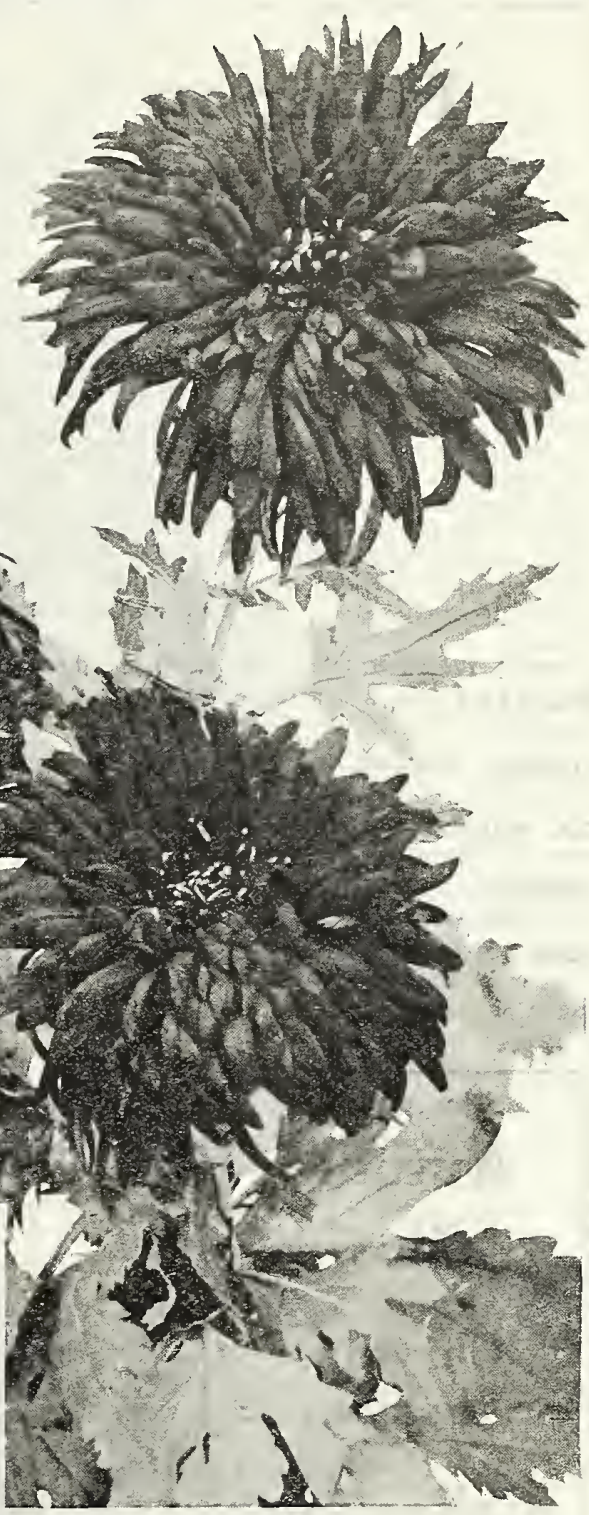

Black Irawk

Chadwick Supreme color beautiof our newest varieties.

Chieftain (NEw) Deep, clear Pink; inof Major Bonnaffon. A very fine midseason pink variety.

White Chieftain (NSw) on the shows a tinge of pink; on the late buds it is pure white.

Roserie (NEW) A good, early Pink.

Helen Frick Medium-sized bloom. Valness. Beautiful Pink. 


\section{Pompon Chrysanthe-}

\section{mums}

From being a comparatively insignificalit section of the Chrysanthemum family, this class during the past few years has leaped into prominence and given the gardening world a wealth of new varieties, beautiful in form and exquisitely colored. While not all varieties are entirely hardy, their inexpensiveness makes a liberal planting worth while even for but one fall show. As potplants, the Pompons are in every way satisfactory and furnish some of the daintiest table decorations of the fall and winter season.

Price, 17c each, 3 for 50c, $\$ 1.75$ per doz. IMARIANA-Pure white in fine sprays for bunching.

QUEEN IOUISE-Dark velvety crimson. Good stem.

IA PORTE-Beautiful bronze. Very attractive when massed with Mariana.

MENSA-One of the largest single whites; resembles a giant Shasta daisy.

MRS. BUCKINGHAM-Resembles Mensa in form and size, but in color a lovely clear shade of pink.

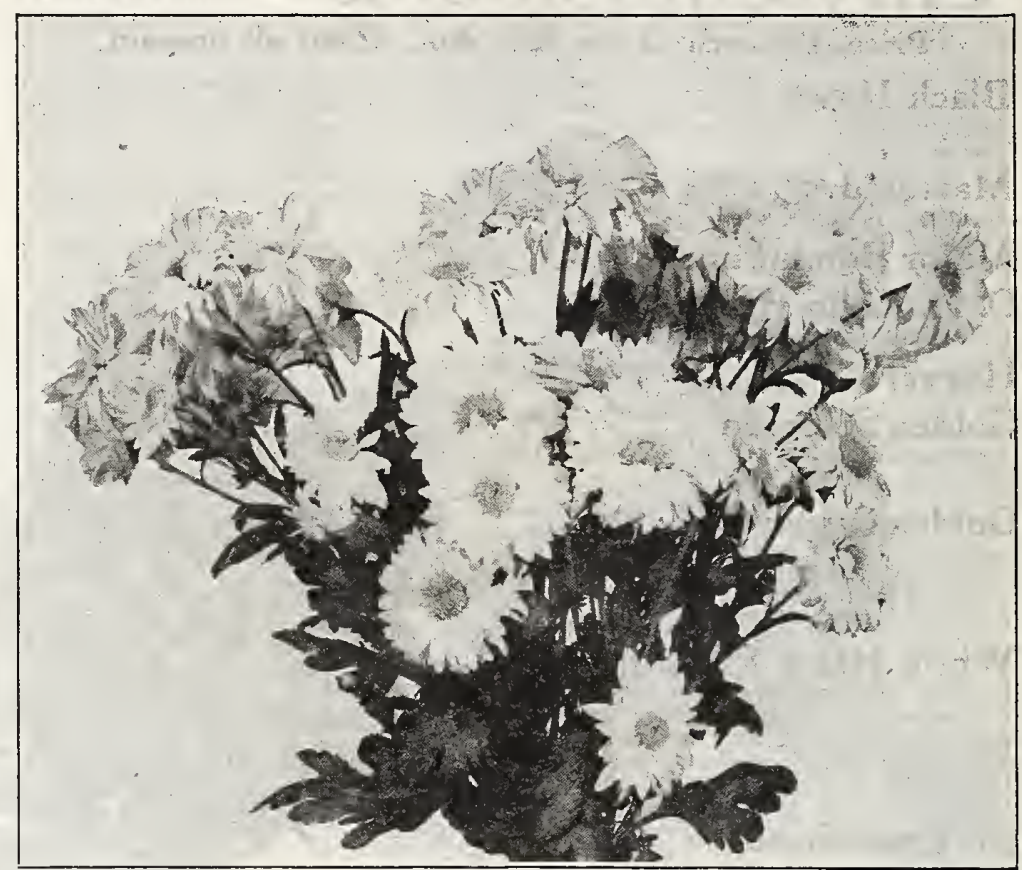

Mensa (Pompon)

WESTERN BEAUTY-Deep rose-pink in color; flower medium size. KIONDYKE-Brilliant yelow; compact blooms of medium size.

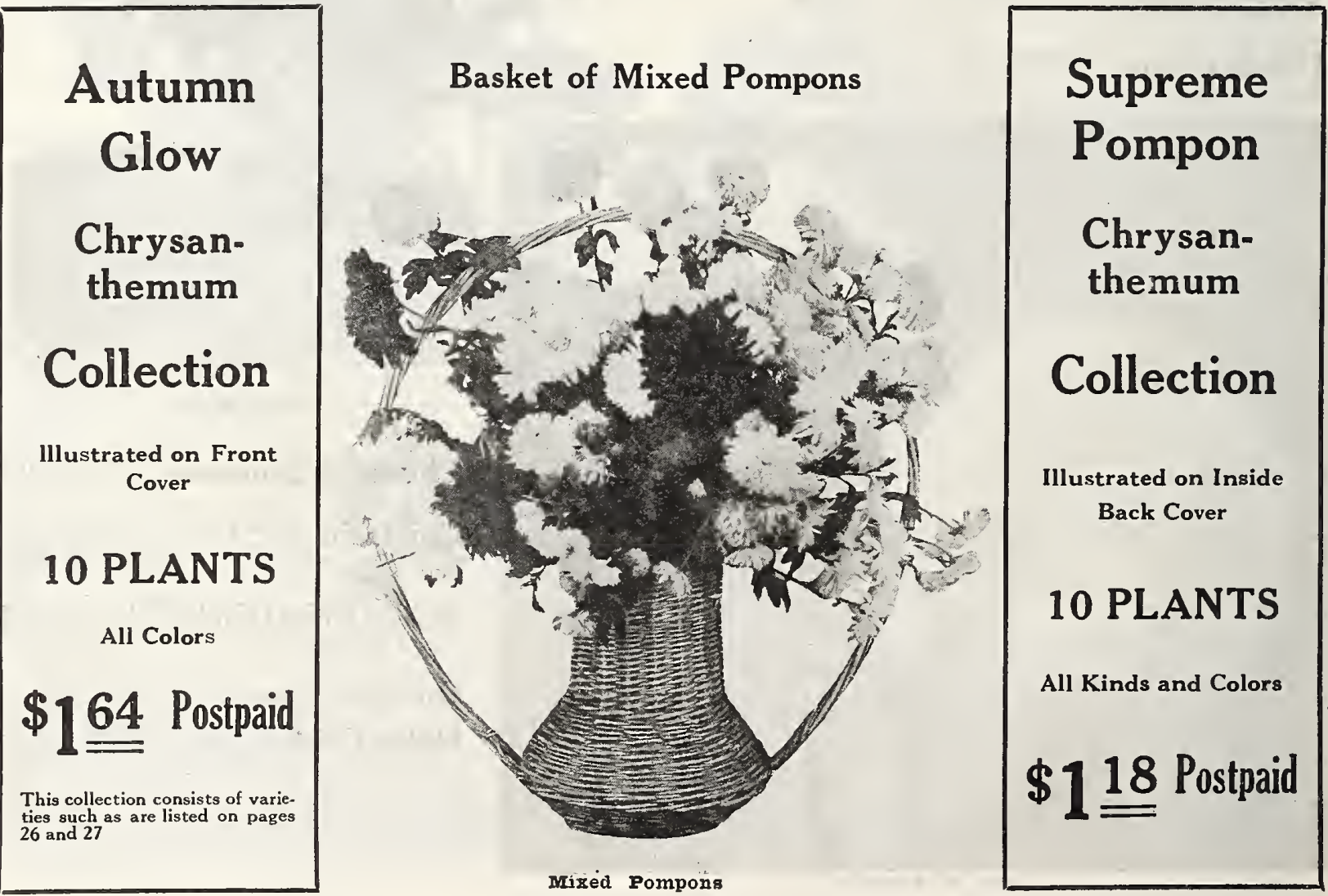




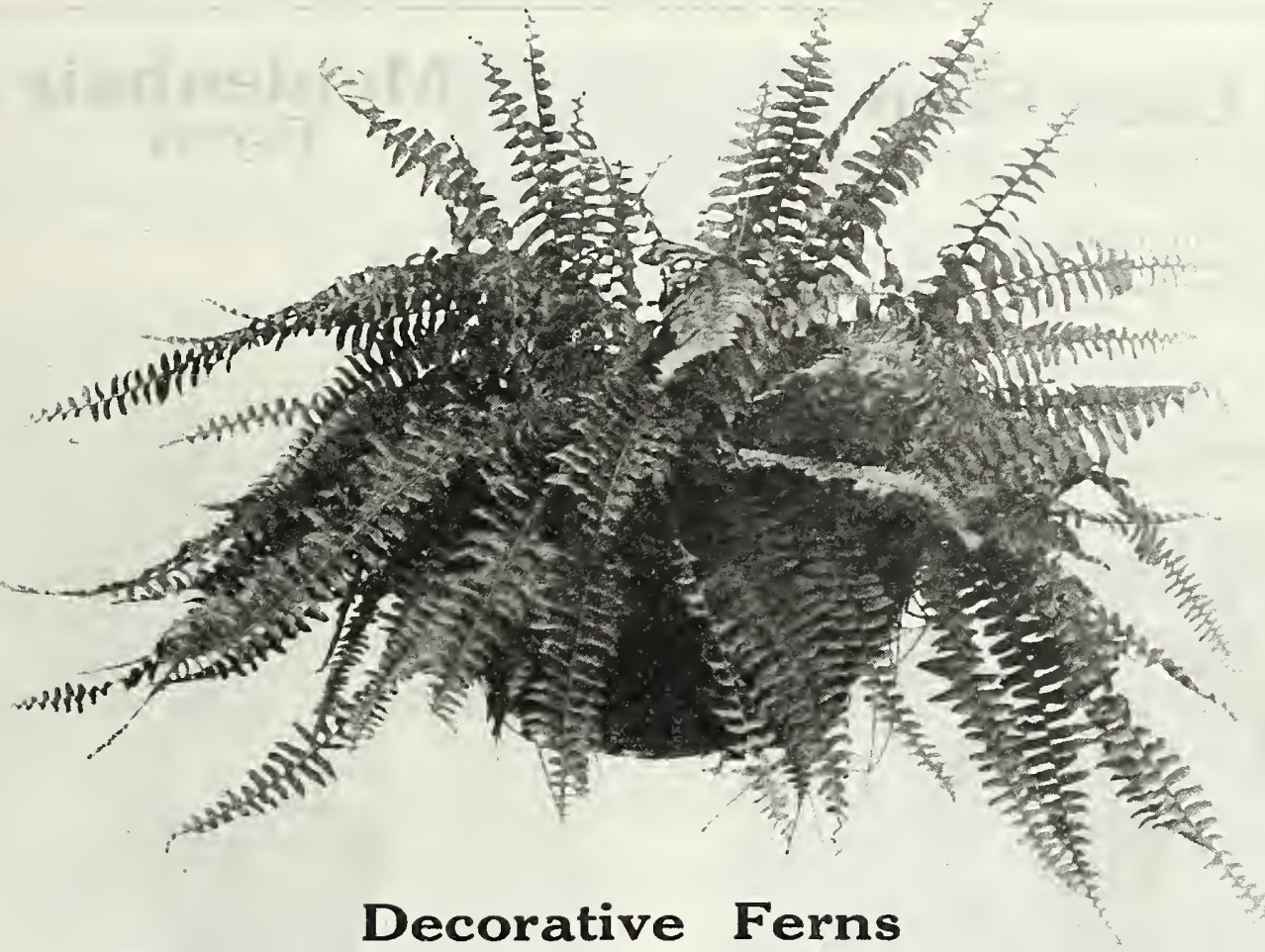

BOSTON FERNS, 6 for $\$ 1.20$.

Above illustration shows wonderful growth made by six small Boston ferns in 90 days time. This is an actual photograph of one of our own ferns.

Now we are giving you the opportunity of a life-time to get a start that will bring the result you see here. Prices, 22c each, 3 for $63 c_{\text {, }} 6$ for $\$ 1.20$. Larger plants 50c, $\$ 1.00, \$ 1.50, \$ 2.00$ each. All prepaid. Specimen plants already having wonderful growth like illustration, $\$ 5.00, \$ 6.00$, and $\$ 7.00$ each by express, only, purchaser paying express charges.

Colture-To grow specimen plants like illustration, place six small ferns in shallow vessel 12 inches in diameter. When planting be sure that the soil does not cover the crowns. Roots must be near the surface, spread out like a spider. Place in a semi-shaded location and protect from strong winds. When watering sprinkle leaves as well as roots. Keep moist but do not allow to stand in water as it will sour the roots and cause the leaves to turn yellow. This also applies to other varieties.

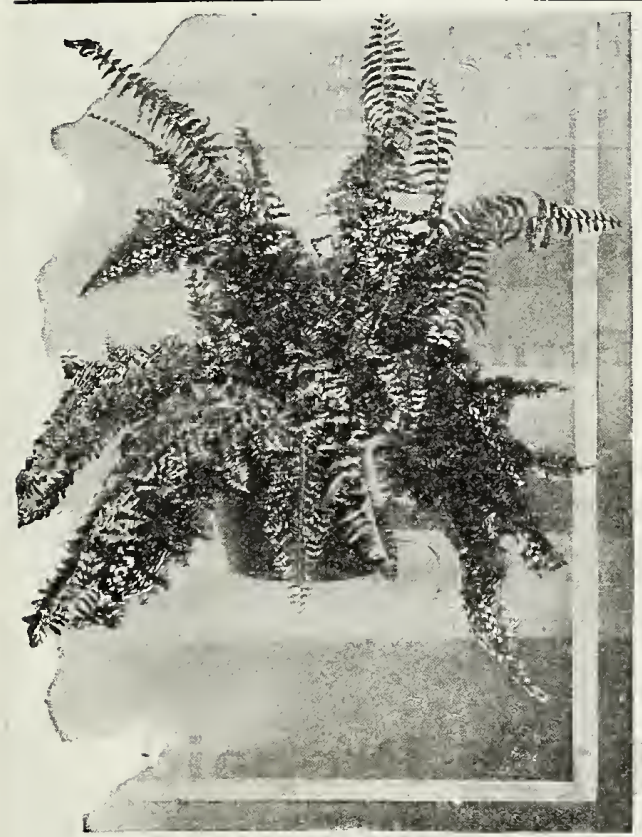

Whitmanil

\section{THE OSTRICH PIUME FERN Whitmanii}

\section{An i $m$ p rove} Tarrytown Fern, of dwarf and compact habit. The pinnae are more deeply divided, giving the plants an exceedingly fluffy and feathery appearance. Price, 25c each, 3 for $70 \mathrm{c}$. Large plants 50c, $\$ 1.00, \$ 1.50, \cdot \$ 2.00$, prepaid.

THE IDEAI FERN

\section{"Woody}

\section{Junior"}

Price 25c each, 3 for 70c, 1 a r ge plants, $75 \mathrm{c}$ and \$1.00. Prepaid.

This magnificent Fern is a sport from the world's renowned Boston Fern. Its habit of growth is to produce longer fronds than its parent plants. The fronds are $n$ a r row and

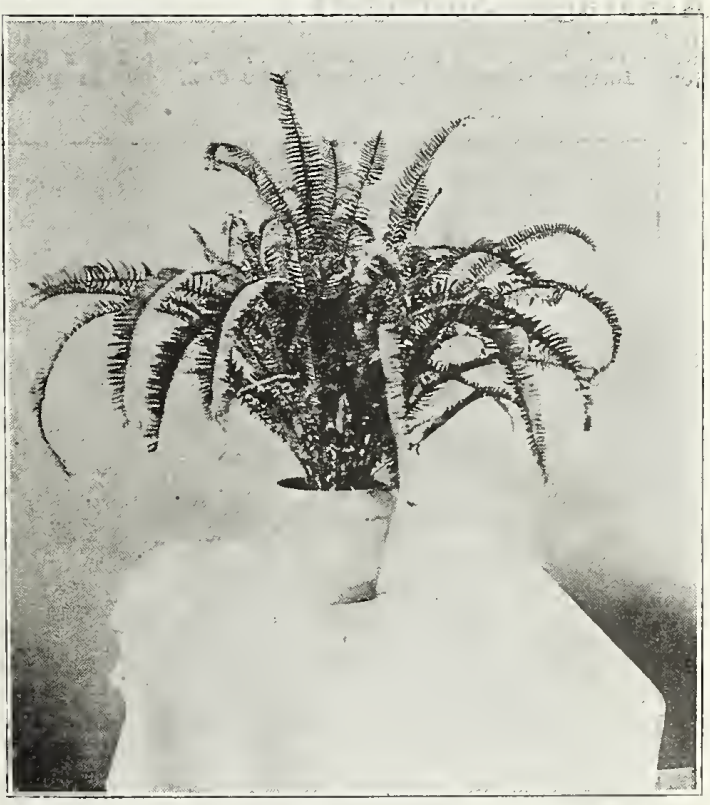

Woody Junior

beautifully tapered from base to tip; they droop just enough to make beautiful and graceful plants. It is such a vigorous grower that it will thrive under most adverse conditions. 


\section{Lace Fern}

One of the Most Beantiful and Popular Foliage Plantis of the Century. A Decorative Plant of Unusual value.

Asparagus Plumosus Fine, lace-like foliage, comSplendid for table and house decorations, bouquets, etc. Price, strong young plants, 25c each; 3 for $65 \mathrm{c}$; plants from 4 in., pots $50 c$ each, all prepaid.

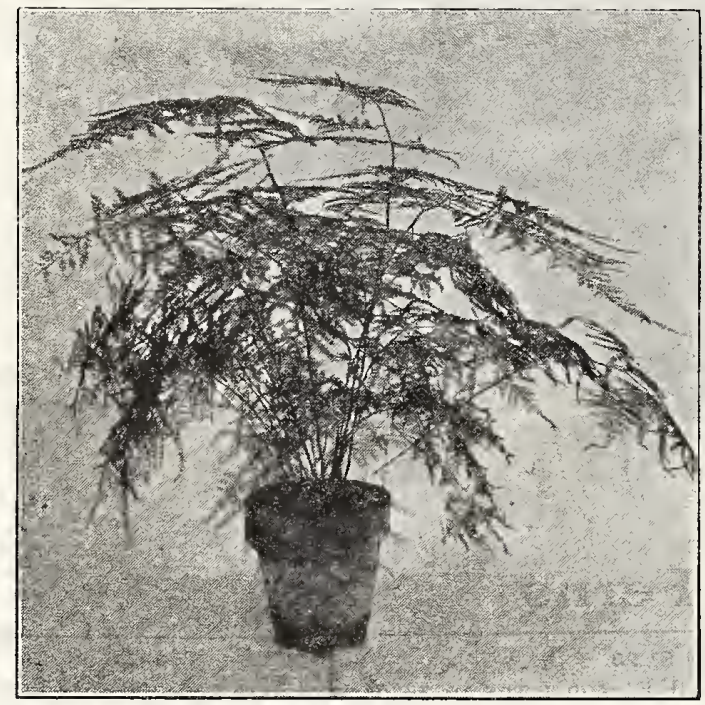

Asparagus Plumosa (Iace F'ern)

\section{Feather Fern}

Unsurpassed for window boxes or hanging baskets. Foliage graceful and drooping, dense glossy green.

Asparagus Sprengeri A fine variety for hanging in its natural grace. Plants also blossom freely and bear in its natural grace, Plants also blossom freely and bear doz. Larger plants, $35 \mathrm{c}$ each; $\$ 3.50 \mathrm{doz}$. All prepaid.

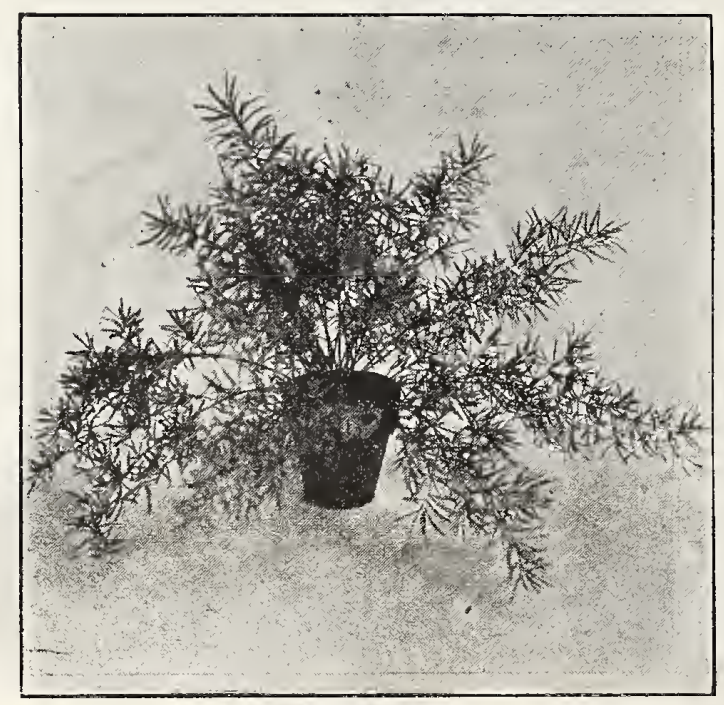

Asparagus Sprengerl (Feather $\boldsymbol{F}$ erx)

\section{Maidenhair Fern}

Its graceful, lace-like foliage makes it indispensable for flower designs or anything where small ferns are used. $25 \mathrm{c}$ each; 3 for $70 \mathrm{c}$.

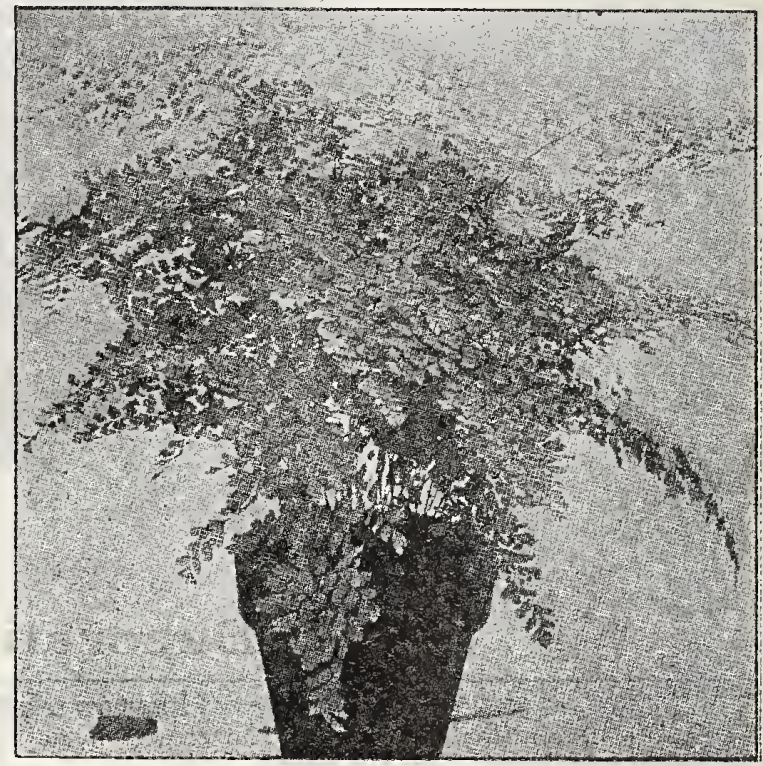

\section{Maidenhair Ferm}

Piersonii Fern Of strong, vigorous growth, with very broad and heavy as they develop. Each pinna or leaflet is subdivided, forming a perfect miniature frond. Price, 25c each; 3 for 65c; large plants, 50c and 750; all prepaid.

Roosevelt Fern The grandest fern of its class yet world-famous Boston Fern. Frice, 25c each; 3 for $65 \mathrm{c}$; large plants, 50c and 75c; prepaid.

\section{"Sun Room" Fern Collection}

Biggest bargain offer of mixed ferns ever listed. This is your opportunity to get a start of some of your favorite ferns. We offer two Boston, two Whitmani, and two sprengeri, making a collection of six lovely ferns, for only

\section{$\$ 118$ Prepaid}




\section{DAISIES}

\section{King Edward VII (Hardy)}

\section{"The Beautiful New Daisy"}

In this novelty we offer the finest semidouble variety that we have ever offered. The color is a pure even shade of white with a clear yellow center. The flowers are large and of excellent substance. The flowers perfectly. The flowers are from 2 towers perfectly. The flowers are from 2 dium height and multiply very rapidly; blooms in early spring. This is a hardier variety than the Shasta. It is an excellent plant for borders. Price, 1
40c, $\$ 1.50$ per doz., prepaid.

Shasta Daisy and plant grows fast It is a fine bloomer. The flowers measure 2 to 3 inches across and are borne on long stems. They have two rows of long, broad white petals and a yellow center. 10c each, 3 for 25c, $75 \mathrm{c}$ per doz.

Dusty Miller Very useful for bedetc. Silvery white toliage. Splendid for cutting and for decorations. Price, loc each, 3 for $25 \mathrm{c}$, $90 \mathrm{c}$ per doz.
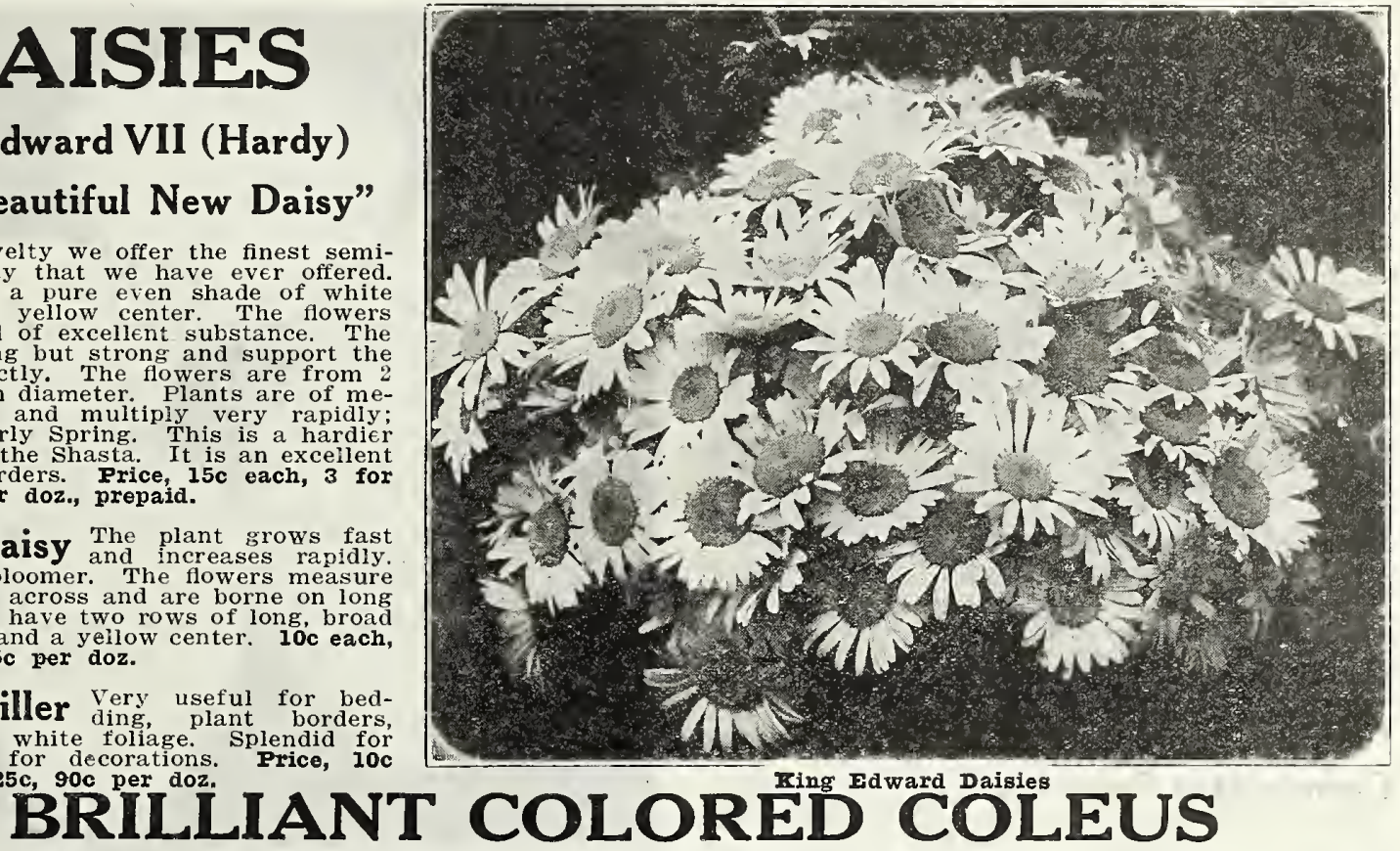

IIIstrated in Colors on Outside Back Cover

We have nothing in the line of bedding plants that can ever take the place of Coleus. There are many of the bright and fancy leafed kinds that are handsomely marked, and this year we offer an unusually large and choice selection of varieties. Beautiful effects may be made by using in solid clumps or as edge to Canna beds, etc.

Write us the shade or color you desire. Price, 10c each, 86c per doz., \$7.00 per 100.

CHRISTMAS GFI-This variety of Coleus cannot be ex- TRAIIING QUEFN-This variety is a very popular on celled as a pot plant. Leaves are immense, being from 6 to as it can be used for bordering beds as well as a trailing 10 inches long, the growth is strong and vigorous. The leaves are bright carmine, shading off to a deep maroon, the margin being yellow and green, the whole leaf having a rich velvety luster. Price, 35c each, 3 for $\$ 1.00$. edges. Price, 15c each; 3 for $42 \mathrm{c}$; doz., $\$ 1.58$.

porch boxes and hanging baskets. The leaves band of deep maroon, with a deep band of green on the Yellow Trailing Queen_- Except for color this variety is in every way like the regular Trailing Queen. The ties planted together make a very pleasing effect. Prices, 15c each; 3 for 42c; doz.. \$1.38.

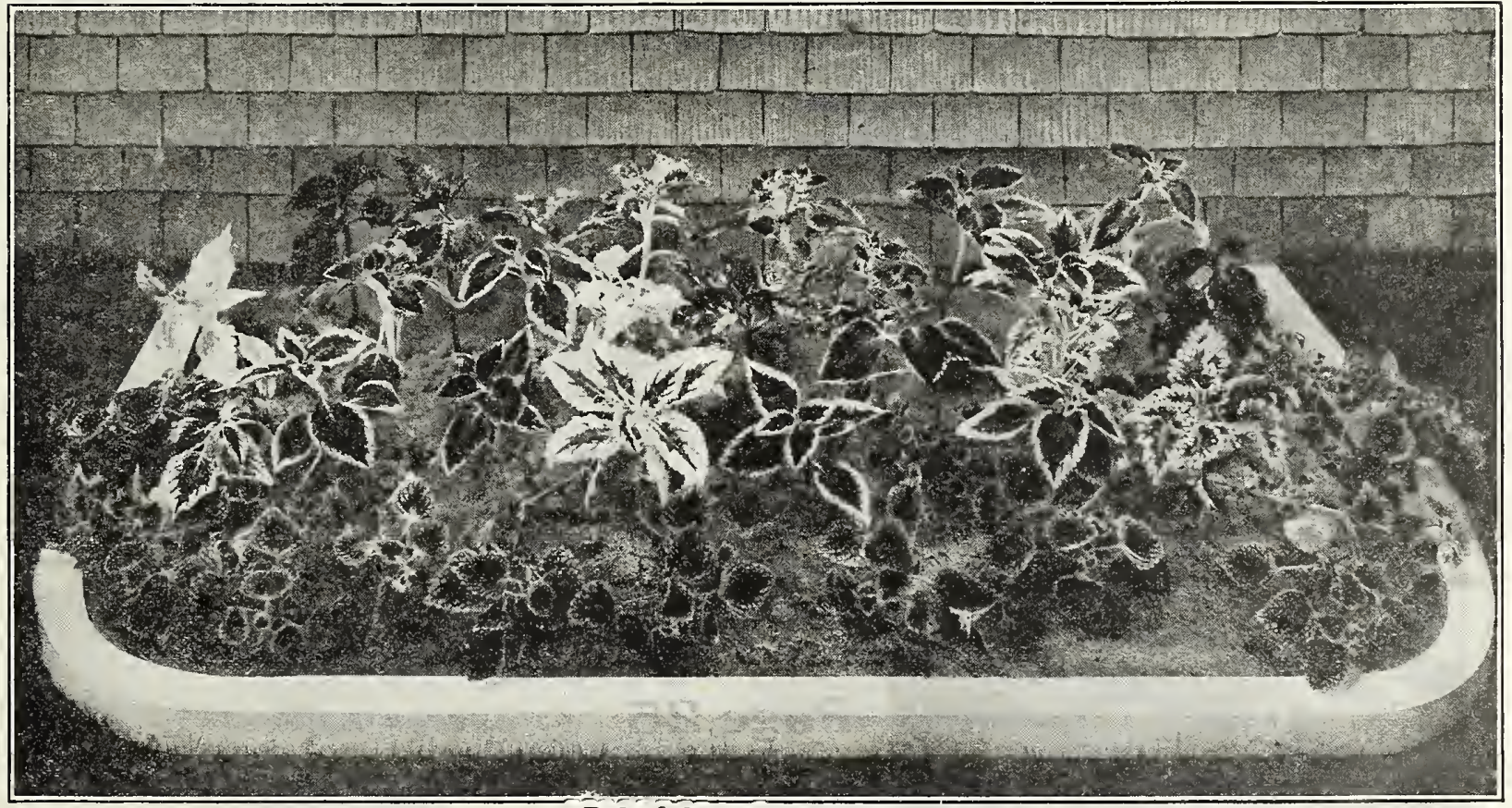




\section{Giant Flowering Hibiscus}

A beautiful class of plants with handsome glossy foliage and brilliant showy flowers, often measuring from 4 to 6 inches in diameter. They grow under the hottest sun and bloom most profusely in open ground or in pots or tubs. The flowers are gorgeously colored. Price of Fibiscus, $17 \mathrm{c}$ each, 3 for 50c, $\$ 1.70$ per doz., prepaid.

Sub Violaceous Flowers of enormous size, of violet; probably the largest flower of the Hibiscus family.

Grandiflora Rich, glossy foliage, blooming proally covering the plant with scarlet-crimson flowers.

Maniatus Semi-Plena Larye, semi-double, tractive; bright vermilion-scarlet; ought to be in every garden.

Versicolor A variety combining in its flowers ing handsomely striped crimson, buff, rose and white.

Aurantiaca Large, double, orange-colored flow-

Carminiatus Perfectus Full, round flowers and of a rich, soft carmine-rose, with a deep crimson eye. A beautiful free blooming variety.

Collerii A remarkably new and distinct variety, introduced from Peach Blow This is one of the finest plant novelties offered in Hibiscus Rosea Sinesis; the flowers are double and from four to five inches in diameter; ồ a charming rich, clear pink color, with a small deep crimson center.

\section{GRAND BEDDING LANTANAS}

One of the most desirable half-hardy perennial greenhouse or bedding plants, constantly in bloom. Verbena-like heads of orange, white, rose and other colored flowers; 2 to 5 feet. Mixed colors. Fine plants, $15 \mathrm{c}$ each, 3 for $40 \mathrm{c}, \$ 1.25$ per doz.

New Weeping Lantana One of the most beautiful plants ever introduced for baskets, vases, pots or its delightfully fragrant lavender flowdrooping habit of growth?

Violet King (New) Cream blending into soft violet.

Mer Jaune ("Yellow Sea") Golden-yellow.

M. Schmidt orange with red.

Comtesse de Biencourt Pink with cream.

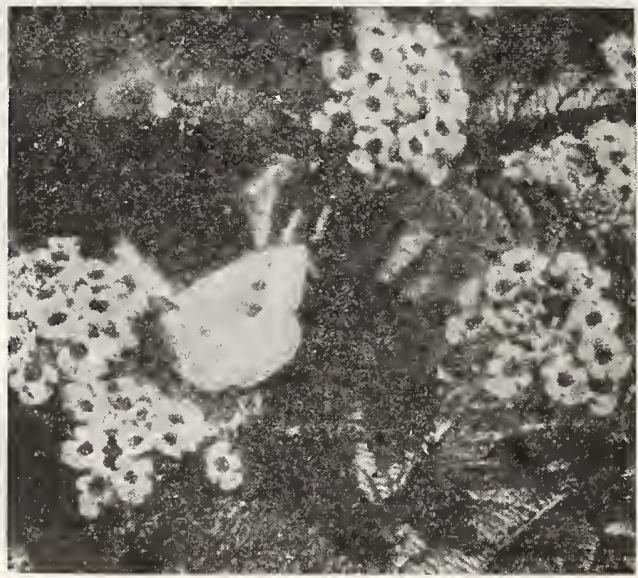

Alba Perfecta

Pure white.

\section{See}

Special

Offers

on

Page 25
Kentia Forsteriana Easy to grow. $48 \mathrm{c}$ each. $\$ 1.00, \$ 1.50$.

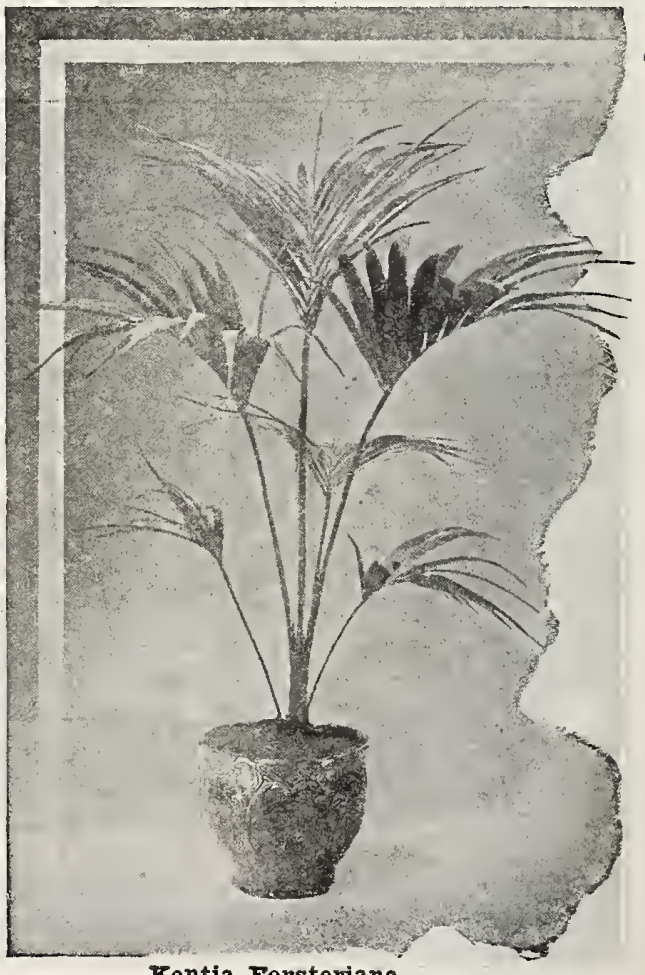




\section{Hydrangeas}

FOR THE PORCH, IAWN AND GARDEN

Beautiful blooming plant, adapted rather for inside decoration. The large clusters of flowers resemble the snow ball, only being much larger.

Otaksa A very beautiful variety from Japan, giving abundance through the season: the flowers are very persistent, lasting two or three months. Fine plants, 30c each.
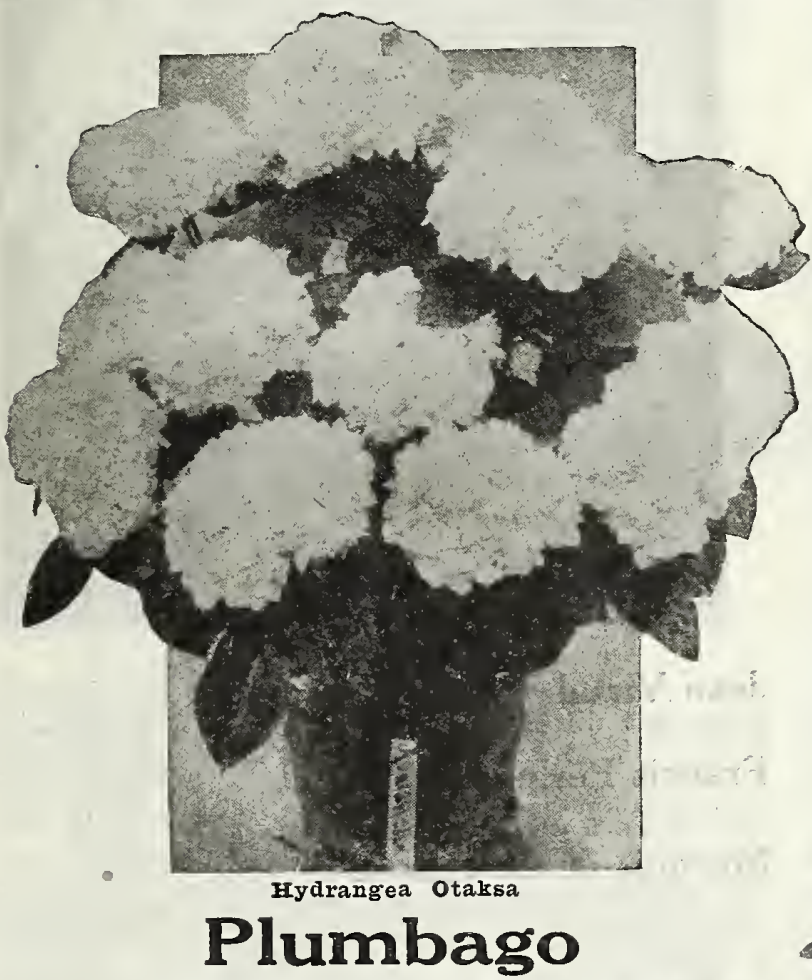

$15 \mathrm{c}$ each; 3 for $40 \mathrm{c}$; $\$ 1.35$ per dozen.

Light Blue One of the finest free flowering plants, cellent for toxes, baskets and pot plants, located in a sunny position. Color light baby blue.

White Exactly like the preceding, except in color, which is clear white.

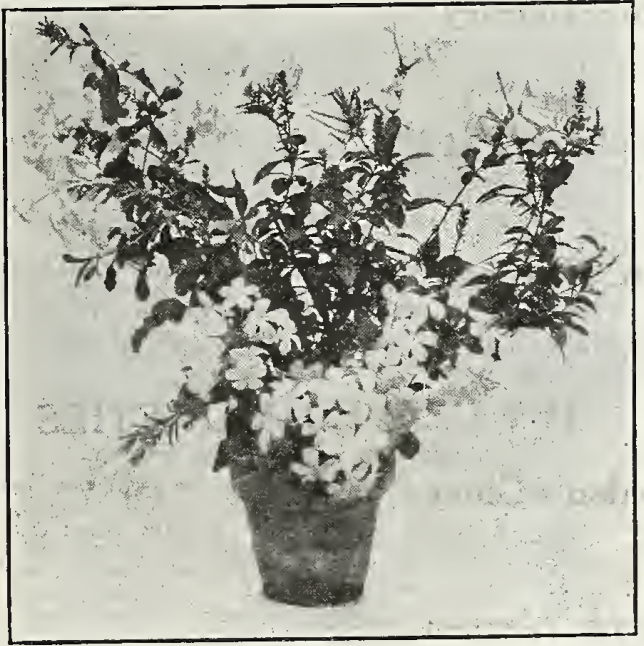

Plumbago

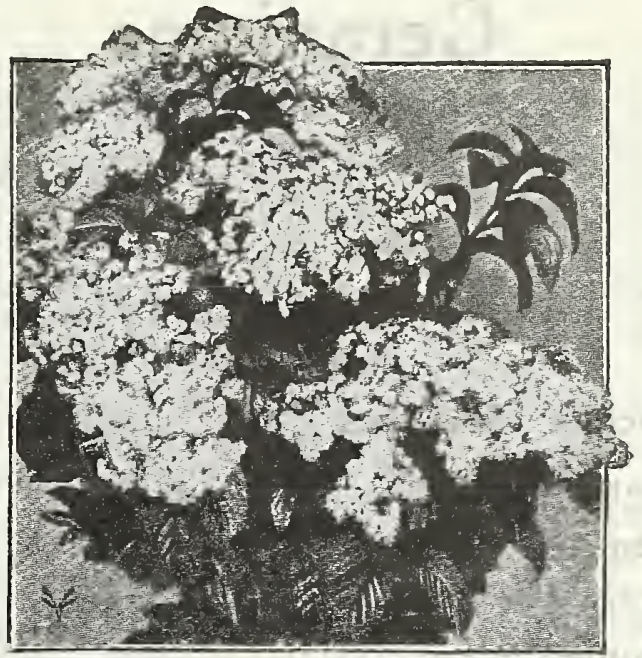

Heavenly Blue Heliotrope

Heliotropes Frice, 15c each, 3 for $40 \mathrm{c}$, $\$ 1.50$ per doz.

Heavenly Blue Large, close panicles of exquisite Grows vigorously and flowers abundantly; very fine for bedding.

Lavender Queen Enormous florets, very large trusses lavender, suffused with rosy mauve a dwarf, robust grower and very free and continuous bloomer.
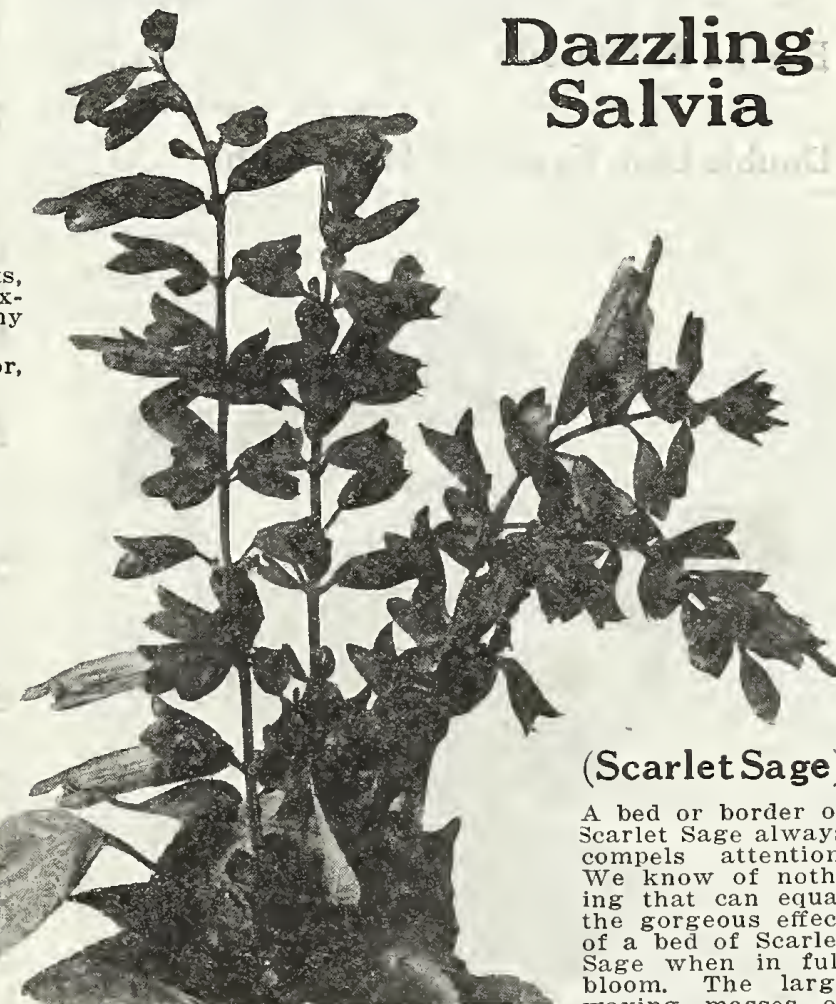

(Scarlet Sage)

A bed or border of Scarlet Sage always compels attention. We know of nothing that can equal the gorgeous effect of a bed of Scarlet Sage when in full bloom. The large waving masses of scarlet bloom against green surroundings of lawn or foliage is matchless. Salvias can be grown in almost any
position with fine effect. Price, $10 \mathrm{c}$ each, 3 for $25 \mathrm{c}, 750$ per doz. 


\section{Geraniums}

Starting with just a few common varieties, constant work has created a vast variety of geraniums that for beauty and richness of coloring are not surpassed by any flower. Geraniums are so extensively grown probably because they are so easy to grow. We sell more geraniums than we do of any other flower. And we grow them by the tens of thousands. Our plants are healthy and sturdy. They are carefully packed so as to reach you in vigorous condition.

Prices-Nice young plants, 22c each, 3 for $63 \mathrm{c}$, per doz. \$2.25; larger plants from 4-inch pots, $60 \mathrm{c}$ each, per doz., $\$ 6.00$.

\section{SINGLE}

Alice of Vincennes Color from beautiful shade of Chade of dark rose pink, with Granville white blotches on base or upper petals. Stands the sun well.

Jacquerie Beautiful deep cardinal red; flne shape and acquerie a good bedder.

Mrs. E. G. Hill Enormous trusses of large florets salmon bordered with rosy salmon. Strong and vigorous. , LAube tire season. Very large florets. One of the best single whites.

\section{DOUBLE}

Buckmer A new Geranium of the large-flowering type and one that has proved to be a fine bedder. dwarf and bushy.

dwarf and bushy: Alphonse Ricard A meautiful shade of bright vertrusses borne in the greatest profusion on long, rigid stems foliage.

Beaute Poitevine Beautiful shade of shrimp pink, sidered to be one of the best semi-double bedders in the sidered to be one or a universal favorite.

ilver Berthe de Pressily rose pink flowers, producing splendid trusses the entire season. This is the best bedsplendid trusses the have and is a suitable companion to the

Double Gen. Grant, or Heteranthe

Color vermilion scarlet, full round forets borne in well branchon long stems; habit all that could be desired, well branchhealthy foliage, with a profusion of bloom.

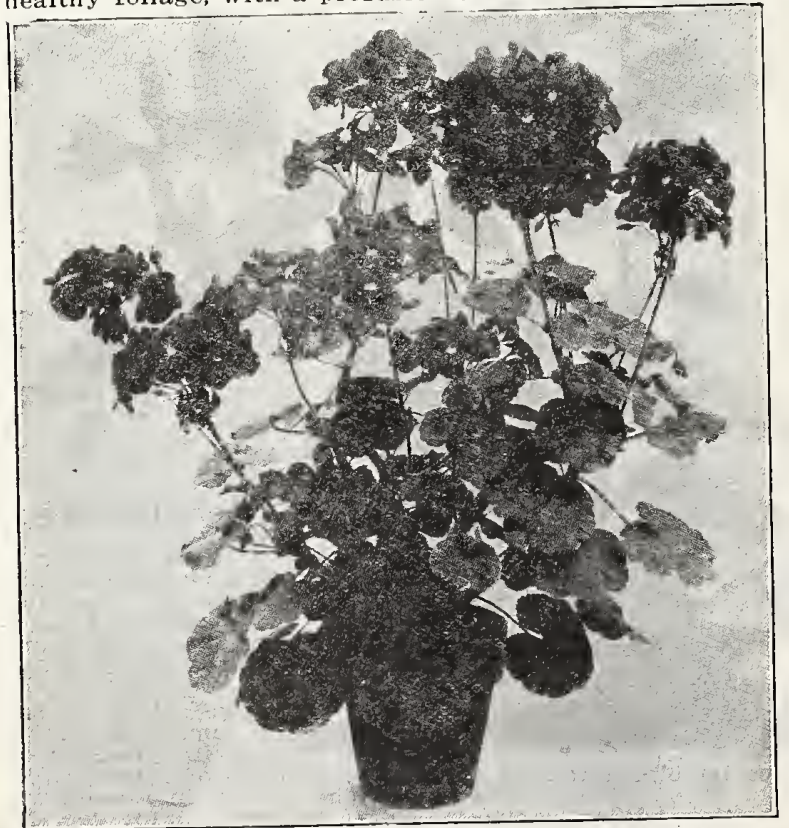

Spaulding Pet Geranium

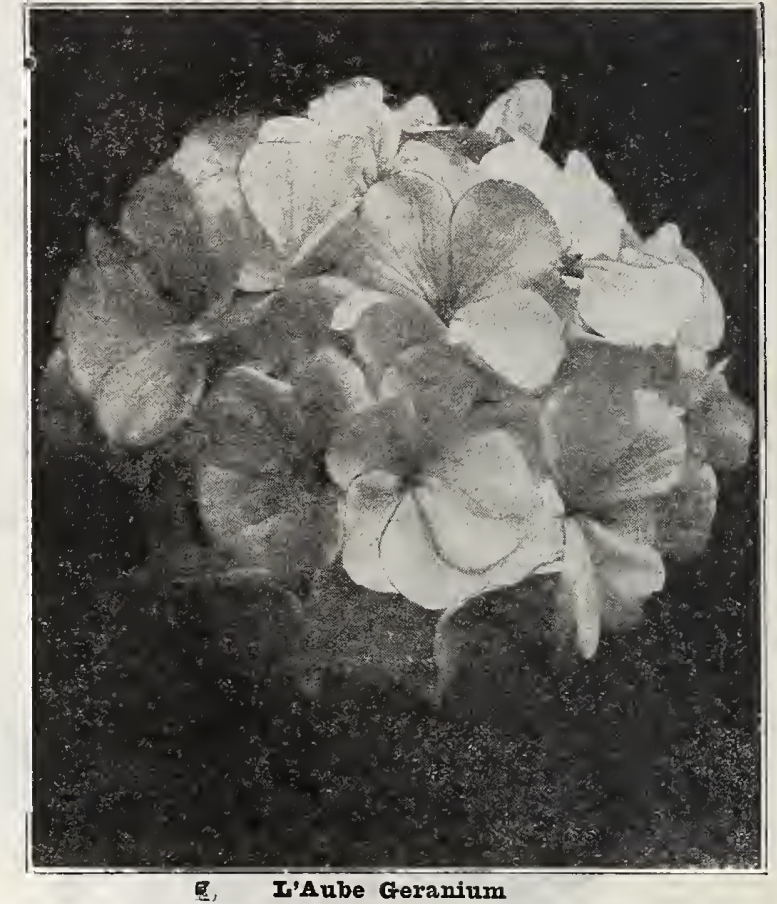

Jean. Viaud Beautiful bright clear shade of mauve flowers and trussese, shading to a clear white throat; the inches in diameter are enormous, sometimes measuring 6 Francis Perkins This is the best double pink bedrancis Perkins ding Geranium; plant is an extra strong, vigorous grower, throwing out tall spikes of large well-formed flowers of a bright pink color.

Marquis de Castellane Immense, beautiful soft ers, varying to a lighter red; perfect in form: large trusses; produced on rigid stems. We can recommend this variety, knowing that it is the healthiest variety we have.

La Favorite One of the finest double whites of its fuse bloomer of enormous flowers; beautiful foliage and finest habit; an excellent white bedder.

Miss Kendall Large, handsome flowers with a scardark carmine red, which is very effective; noble upright habit; round and full florets. Mme. Landry A distinct, salmon-pink with a light and florets borne on long stems; semi-dwarf and vigorous habit. With its noble upright nature it is capable of standing the extreme heat. An excellent pot variety, being an early bloomer.

Spaulding Pet This is a profuse bloomer with large, Scarlet flowers, semi-double, and has the remarkable faculty of blooming right through the hottest and driest weather; it also is a Iuxuriant grower. This is a variety that is especially desirable for the South.

S. A. Nutt The most beautiful of all dark-red varieroon shading. Compact, vigorous growth. Constantly in bloom. Stands heat and drouth better; is therefore the best outdoor Geranium. We have a large stock of this splendid type.

\section{IVY-LEAVED VARIETIES}

\section{Price 22c each, 3 for $63 \mathrm{c}$}

Carden's Glory A profuse bloomer of an exquisite Garden's Glory bright scarlet double flower, which is considered to be one of the best of this type; the plants display a continual profusion of bloom and are of exuberant, healthy growth; flowers are of good quality, and large size, pleasing and attractive for fancy baskets and vases. Joseph Warren A very large, bold semi-double being a lovely shade of rich purple, rose slightly feathered dark maroon: a distinct and striking variety. 


\section{Sweet Scented Leafed Geraniums}

"Extensively Grown for Their Fragrant Foliage"

This beautiful and useful Geranium is now very extensively grown for its highly fragrant foliage, and to be used among cut flowers which have no perfume of their own, as well as in making toilet waters, fragrant jars, flavoring jellies, etc.

Rose This variety has been a great favorite since each, 3 for $50 c$.

Apple Apple scented. Lemon Dwarf, glossy, small green leaves, delightful

\section{Everblooming Easter Greeting} Pelargonium This new Everblooming Greeting) is the most wonderful flowering: variety of all Pelargoniums. Blooms from late winter to early fall, withstanding the summer heat. A brilliant rose. Each of the petals is marked with a large darl. the petals in the center, being daintily penciled with a scarlet crimson. Price $30 \mathrm{c}$ each, 3 for $75 \mathrm{c}$.

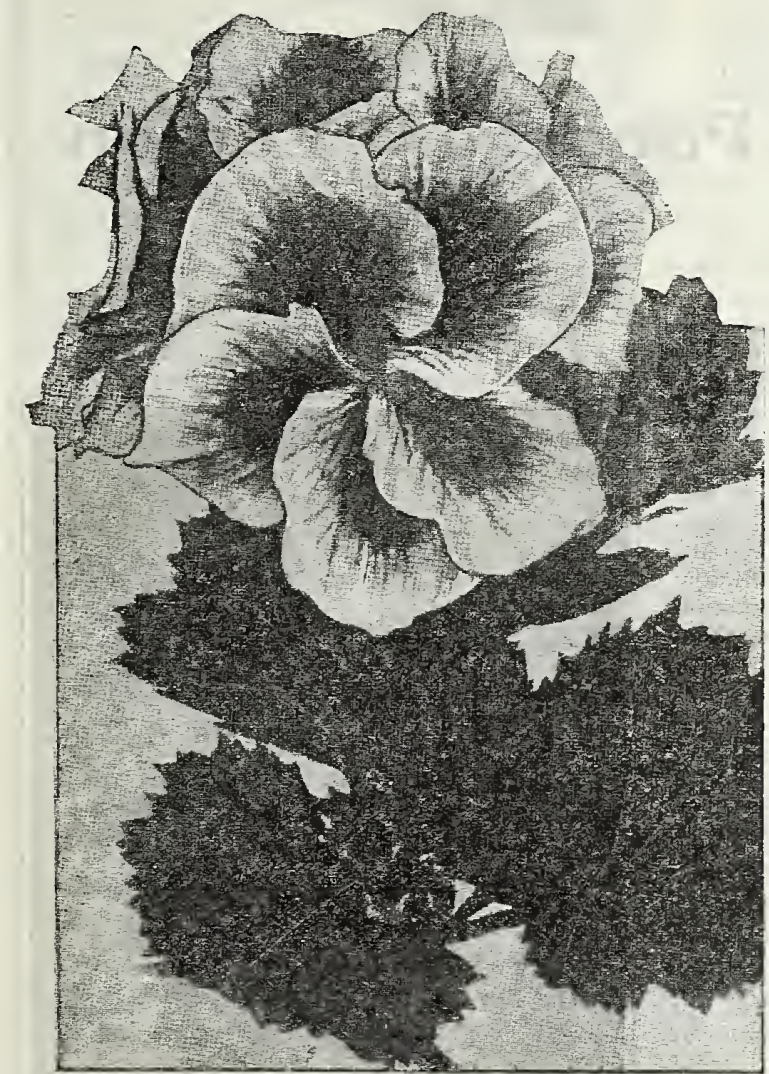

Pelargonium Faster Greeting

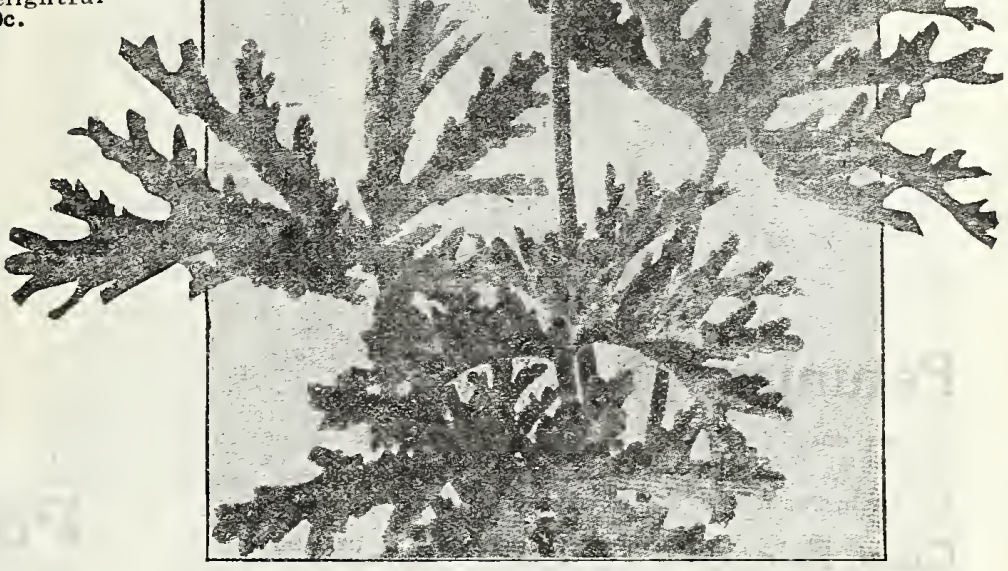

Sweet Scented Cut-Ieaf Rose Geranium

\section{Phlox}

PHIOX DRUMMONDII-Brilliant and abundant large terminal flowers, which completely hide the foliage; the blooms minal owars colors, from pure white to deepest purple, eyed and striped. Give good rich ground and set plants 6 inches apart. White, rose, scarlet, deep blood, or mixed colors. $10 \mathrm{c}$ each, $65 \mathrm{c}$ per doz., $\$ 5.00$ per 100 .

\section{Fruiting Orange}

Dwarf, bus h y plants which bear a profusion of fragrant flowers and edible fruit. The best of the oranges for house culture. Price 35c each.

Oleanders Nothing nicer for porch or lawn decof molsture during growing season. May be wintered over in any cellar where it does not freeze. Double pink, $35 \mathrm{c}$ to $\$ 1.00$; double white, 35c to $\$ 1.00$.

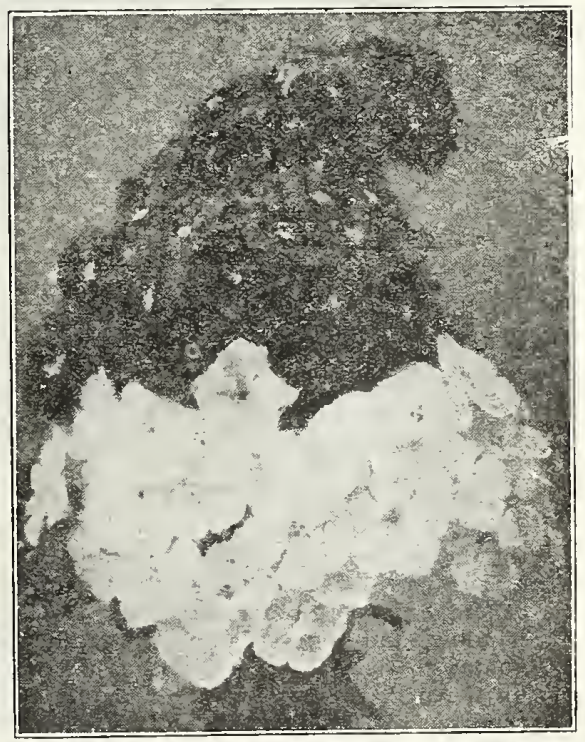

Phlox 


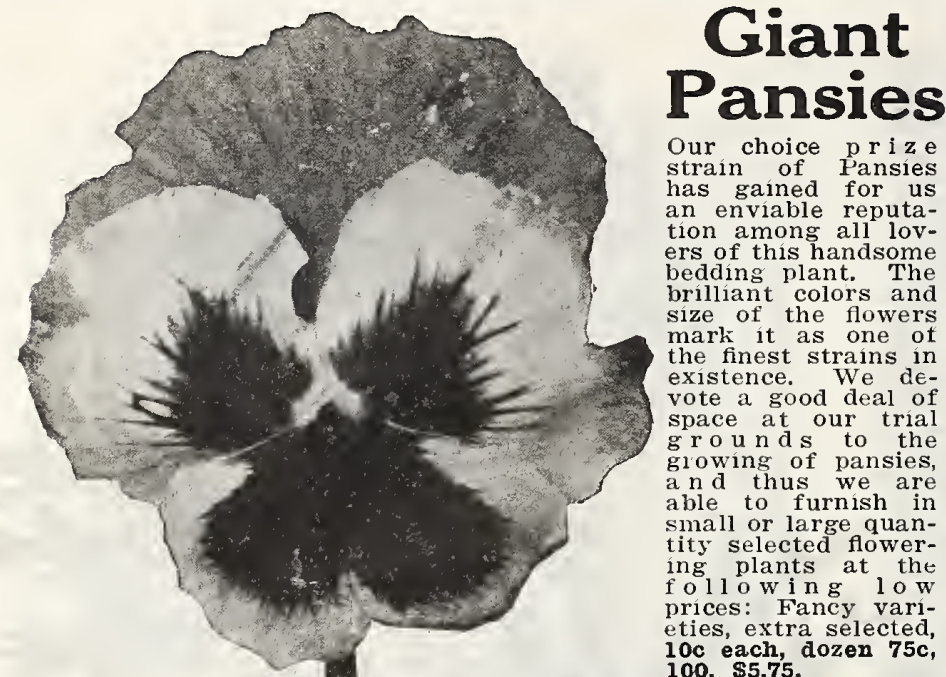

SINGIE PETUNIAS. It is rapidly becoming known that Petunias are the most popular of all annual bedding plants as well as most desirable for porch and window boxes, baskets, etc.

They are admirably well adapted to

\section{Petunias}

our hot, droughty climate and present a wealth of beautiful and varied blooms are to be found in almost every lawn and will, as they become better known, appeal to everyone. Our assortment embraces all of the desirable varieties of single, including pure white, all shades of pink, red, striped star, mottled, etc. Do not overlook these lovely plants. Price, $10 \mathrm{c}$ each, 75c dozen, \$5.75 per 100.

Giant Fringed These Petunias thrive and bloom the weather, ard are fine for flower beds or house culture. Separate colors: White, Pink, Variegated, Crimson and Maroon. $15 \mathrm{c}$ each, 3 for $40 \mathrm{c}, \$ 1.50$ per doz.

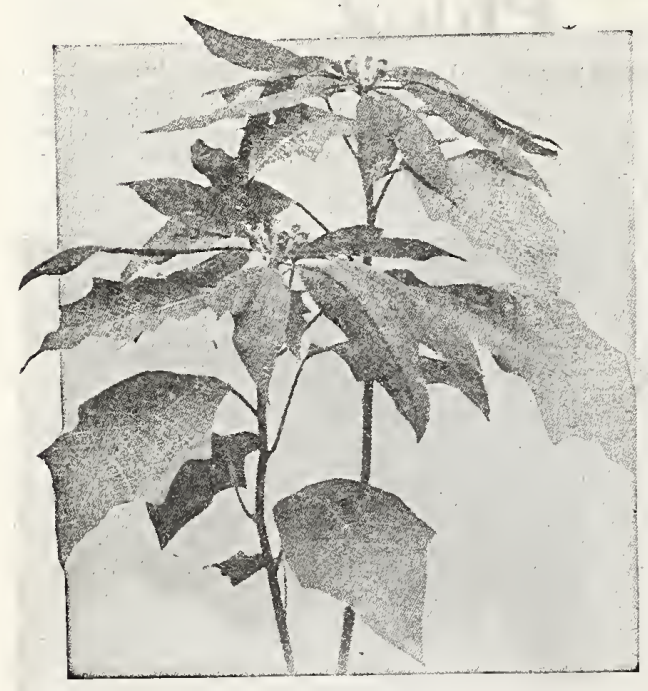

Poinsettia

\section{Ponderosa Lemon}

Splendid, strong, growing plant of the citrus family. It not only makes a lovely house plant, but produces large, handsome lemons which will be the delight of the housekeeper. It produces these splendid fruits year after year, beginning to bear when the plant is two years old. As the plants grow larger, they produce more fruit; on a tree six feet high ninety lemons were grown at one time, ranging from the size of a pea to ripe fruit, demonstrating the truly overbearing habit of this variety. The fruits grow to a very large size, have remarkably thin skin, and are the juiciest of all lemons. Excellent for lemonade and other culinary purposes. Thirty plants, $35 c, 50 c$ and $\$ 1.00$ each.

\section{Poinsettia}

A grand plant especially adapted for Winter flowering. They begin to bloom in November and remain expanded until February, and are exceedingly showy. The individual flowers keep perfect many weeks before fading so that for nearly two months this grand bloom is in full glory. The color of the flower is a brilliant, dazzling scarlet and sure to attract great attention. We sell more of this plant for Christmas gifts than any other variety of blooming plants. They will thrive well in any sunny window, and require about the same treatment as a Geranium or Begonia. After they are through blooming they should be dried off until April, then the old soil should be shaken off the roots, the plants repotted in fresh garden soll, after which they will start a new growth and make fine plants for the next season. Price, $30 \mathrm{c}$ and $50 \mathrm{c}$ each.

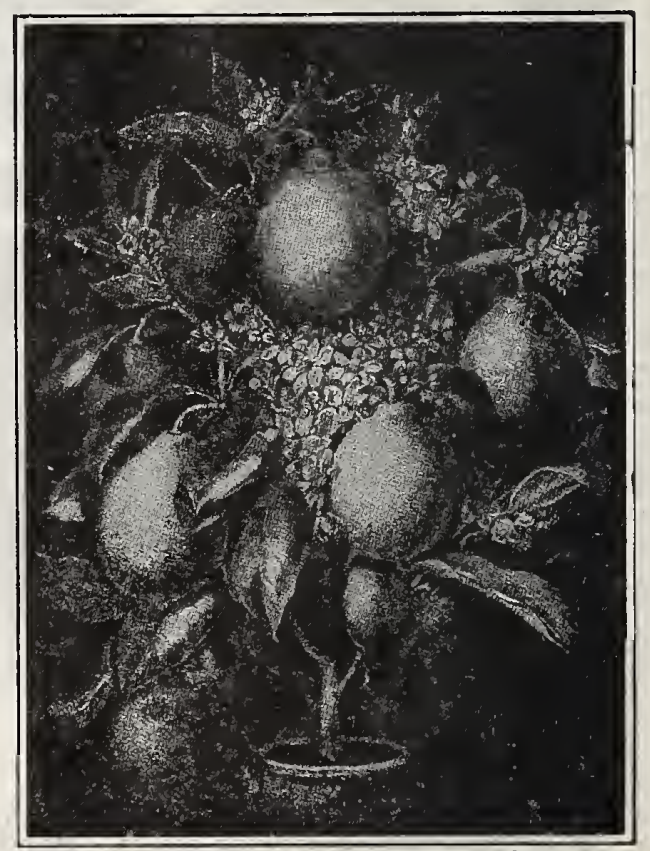

Ponderosa Lemon 


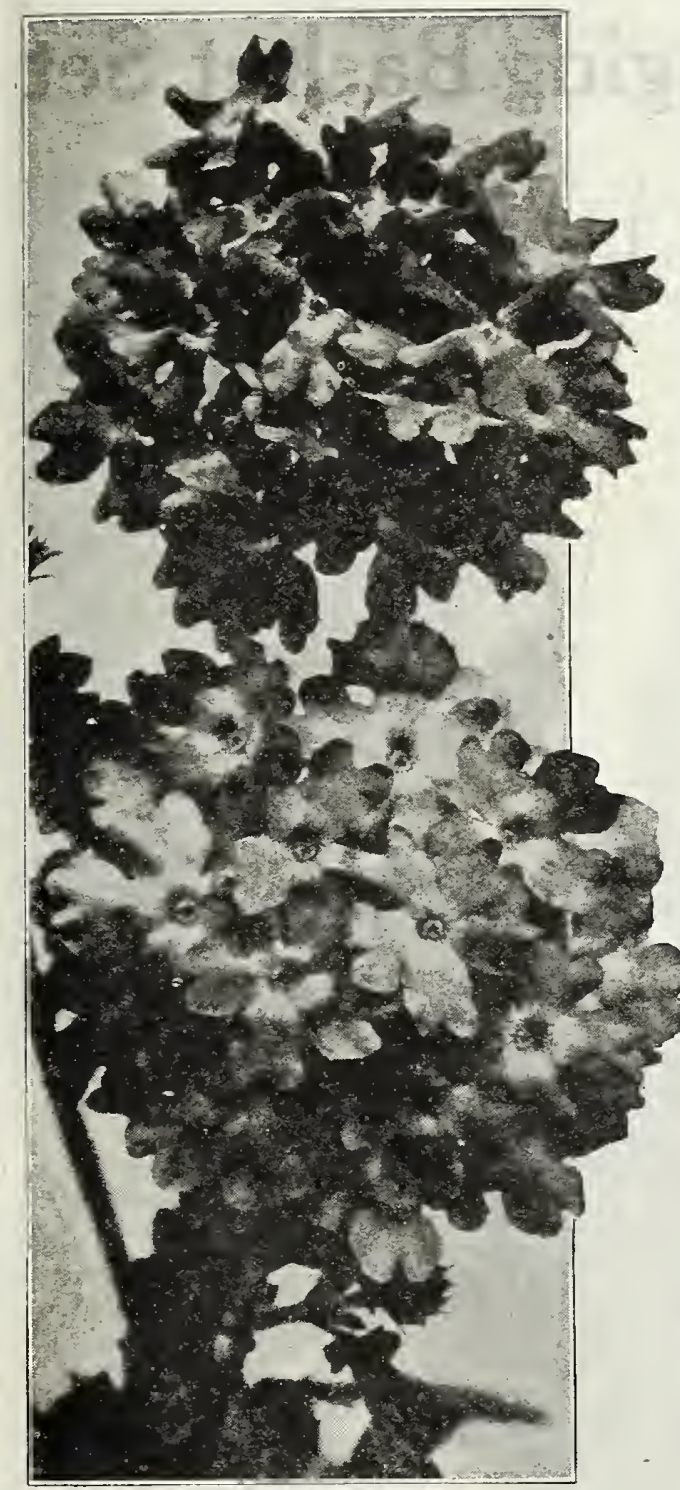

Mammoth Verbena

Mammoth Verbenas The collection we offer is as fine a coltinent, containing the most brilliant colors and some right fragrant varieties. In order to keep the plants in the best blooming condition, cut all faded flowers off, and even a severe trimming or clipping tends only to strengthen the plants and keep them in better shape for late flowering. With proper care your Verbenas may be kept in blossom long after other flowers have gone. The demand we had the past season for this popular flower was enormous. Red, white, purple and pink. Price, 10c each, 6 for $55 \mathrm{c}, 12$ for $\$ 1.08$.

Violets A few plants of this modest but popular favorite should Giants of California single flowers of deepest blue or purple Large quantities of this variety are grown for cut-flowers. Splendid for bouquets. $7 \mathrm{c}$ each, 3 for $20 \mathrm{c}, 75 \mathrm{c}$ per doz., $\$ 5.50$ per 100 .

75c per doz.

Princess of Wales New single violet. This variety is far ahead growth, the plants are wonderfully free flowering, with stems from 10 to 12 inches long; large leaves of a thick, leathery texture. The grand single flowers of a true violet blue color that does not fade, are of round, symmetrical form, almost as large as pansies, and of the richest, most delicious fragrance. So large and circular are the flowers that some blooms will cover a silver dollar. Price, $10 c$ each.
15 for $\$ 1.00$.

\section{Vinca- \\ Madagascar Periwinkle}

This is fast becoming the most popular bedding plant for the Southwest. The weather never seems to be too hot or too dry for it, and, in fact, it seems to flourish best in hot weather. The foliage has always a bright, glossy, healthy appearance, which, in itself, is and the plant is never without an abundance of beautiful flowers from the time it begins to bloom in May or June until killed by heavy frosts in November. This is a plant you can depend upon to produce a wealth of lovely blossoms, in any soil and under almost any conditions-it is at home in any position. $10 \mathrm{c}$ each, $\$ 1.00$ per doz., $\$ 6.00$ per 100 .

Alba Glossy leaves: beautiful.

Rosea Rose-colored dark $\in$ ye. Pink Eye ${ }_{w}^{P}{ }_{h}{ }_{i}$ t e with distinct pink eye.

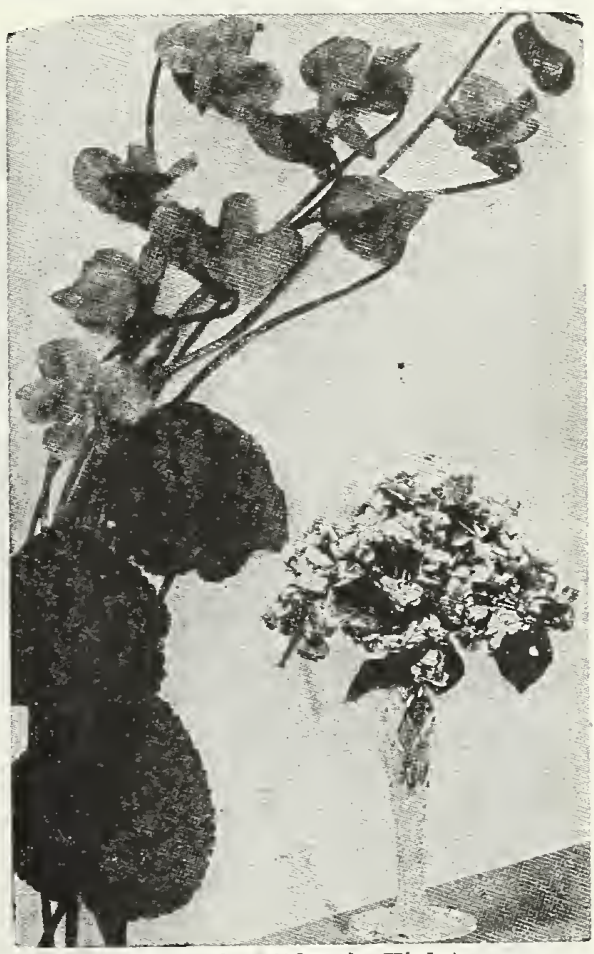

Grants of California Violet

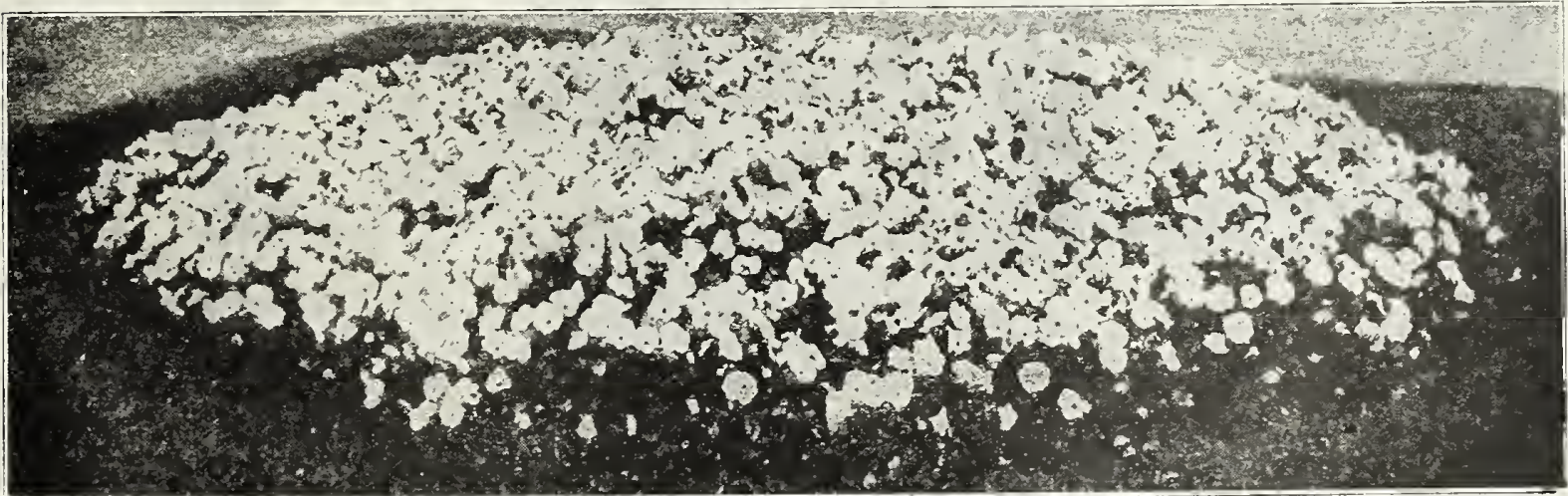




\section{"Home Beautiful" Hanging Basket Set}

We will send you by parcel post prepaid for $\$ 2.25$ this beautiful Hanging Basket Set, regular value $\$ \mathbf{3 . 5 0}$. It consists of basket, hanger, moss with which to line basket, and ten assorted plants suitable for this purpose. Ferns, blooming plants, and trailing vines make up the assortment of plants included in this set. Complete directions for filling basket sent FREE with each set.

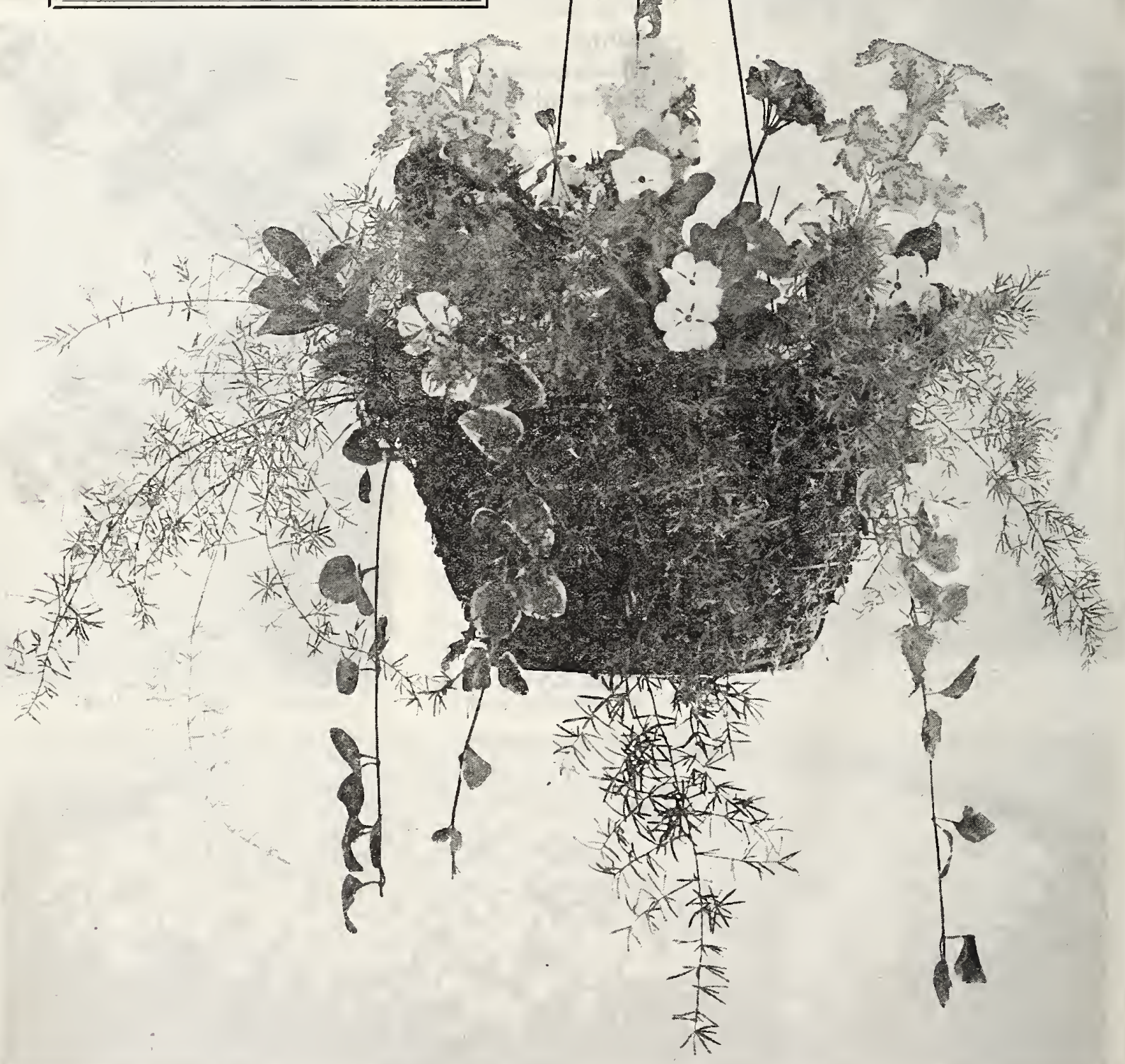




\section{Hardy Climbers}

Once established, these beautiful climbers grow more beautiful each year, increasing in size and strength, with no more attention than a covering of rich manure in the fall and spading in the spring. Every home should have one or more of them. They make cemeteries, etc., much more attractive.

Wistaria, Chinese Blue There is novine in its effect than the Wistaria, its loug, twining branches bearing great sprays of compound foliage, climbing in graceful, artistic curves even to the top of a tall building, while its charming racemes of dainty light purple or blue flowers in May sway with every passing breeze. For porch decoration without too much shade they have no superior. Price, 50c each, 3 for $\$ 1.40$.

White This differs from the Chinese only in color forming a striking contrast. 50c each, 3 for $\$ 1.40$.

Matrimony Vine A general utility hardy overcome any obstacle to growth and flourish everywhere. Every new shoot produces handsome purple flowers and later a prodigious crop of scarlet berries, nearly an inch long. Frice, 50c each, 3 for $\$ 1.40$.

\section{Madeira Vine The Madeira Vine is of rapid} tiful foliage, twining to where, but does better in a warm, sunny, sheltered location. It is also a very pretty plant for training alound the windows in the house. Strong tubers. Each 12c, 3 for 32c, per doz. \$1.00.

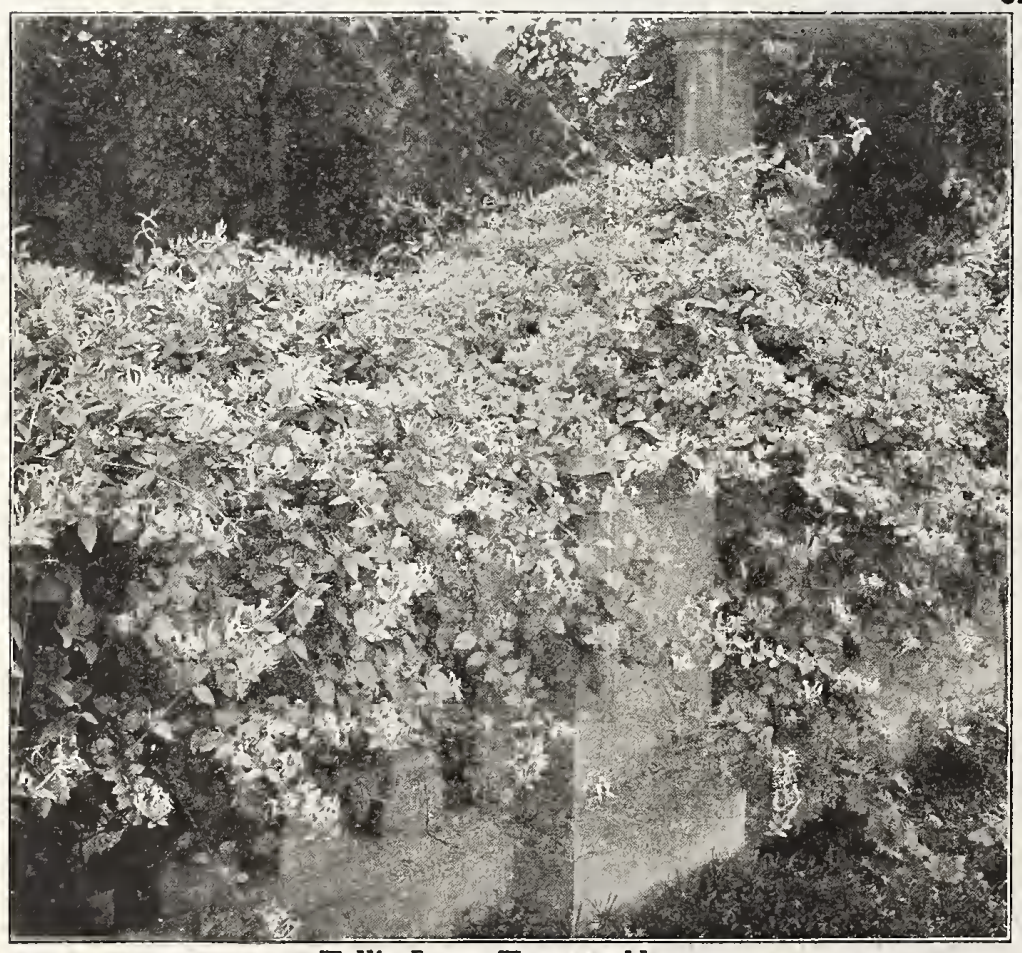

Chnnese Blue Wistaria

\section{Honeysuckle}

The dear old Honeysuckle is never out of place, at the rich man's mansion or the poor man's cottage. For a cheap, hardy, robust, yet lovely vine, it is the chief standby. All field-grown plants.

Hall's Japan The best white with dark green folíage, which keeps fresh and green nearly all winter, and beautiful clusters of the sweetest scented flowers that open a snowy white and turn a pale yellow. These flowers are produced in profusion from early spring to late fall. Price, 40c each, 3 for $\$ 1.10,1$ doz. $\$ 4.00$.

Rosea Evergreen, dark green foliage; Rosea young sprouts have pink leaves; flower white with pink. Price, $40 \mathrm{c}$ each, 3 for \$1.10.

Golden Leaved Marvelously effecnumerable sprays of the most perfect little leaves that are covered with a network of gold and green, often marked with pink. The gold deepens at the tip of the sprays. A strong grower with white blossoms. A unique vine, Price, $45 \mathrm{c}$ each, 3 for $\$ 1.25$. 


\section{HARDY CLIMBERS-Continued}

\section{Robinson Beauty Vine}

-Illustrated in colors on outside back cover. Sometimes called Mountain Rose and Queen's Wreath.

This new climbing vine of striking and remarkable beauty comes to us from Central America, where it abounds and is said to color the mountains with a blaze of growing pink. It is a strong, vigorous climber, suitable for covering walls, porches, verandas and fences. It has handsome foliage and is covered with splendid clusters of bright pink flowers during September and October, after all other climbers have ceased to give bloom. It is certainly unequaled in brilliant beauty among climbing vines, and we are sure it will give our customers immense satisfaction. Strong plants 25c. Extra large plants $50 \mathrm{c}$ each. Postpaia.

Hardy English Ivy Evergreen variety, largely used for covering walls, trellises, arbors, etc. Will stand the most severe winters without protection. May also be grown in pots and forms splendid live screen for windows, etc. Strong plants $25 \mathrm{c}$ each, 3 for $65 \mathrm{c}$.

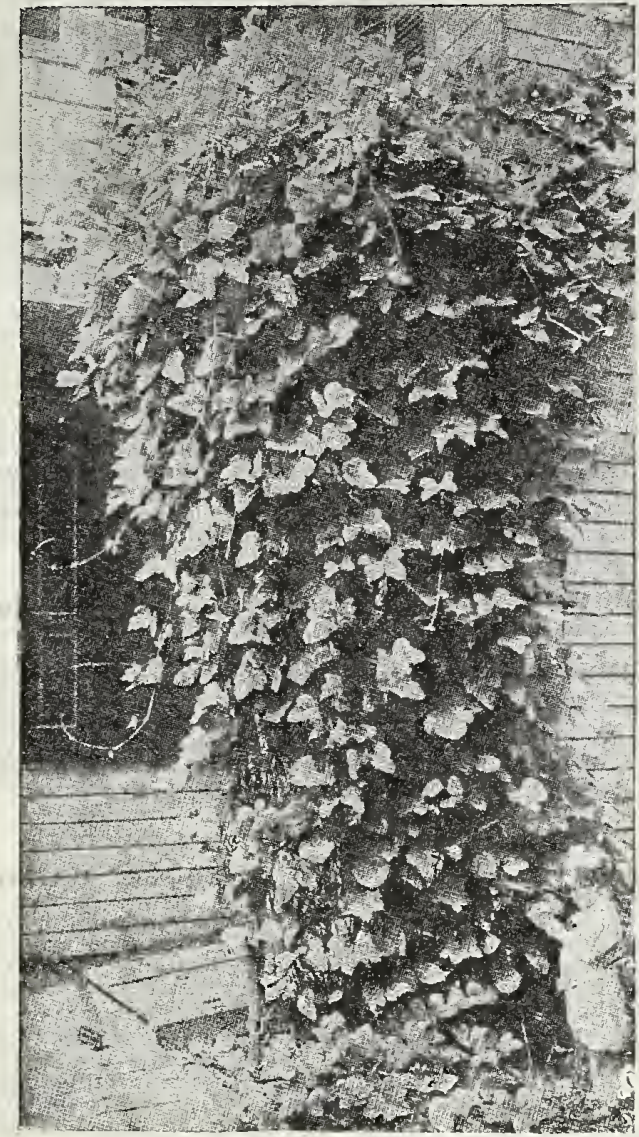

Kudzu Vine

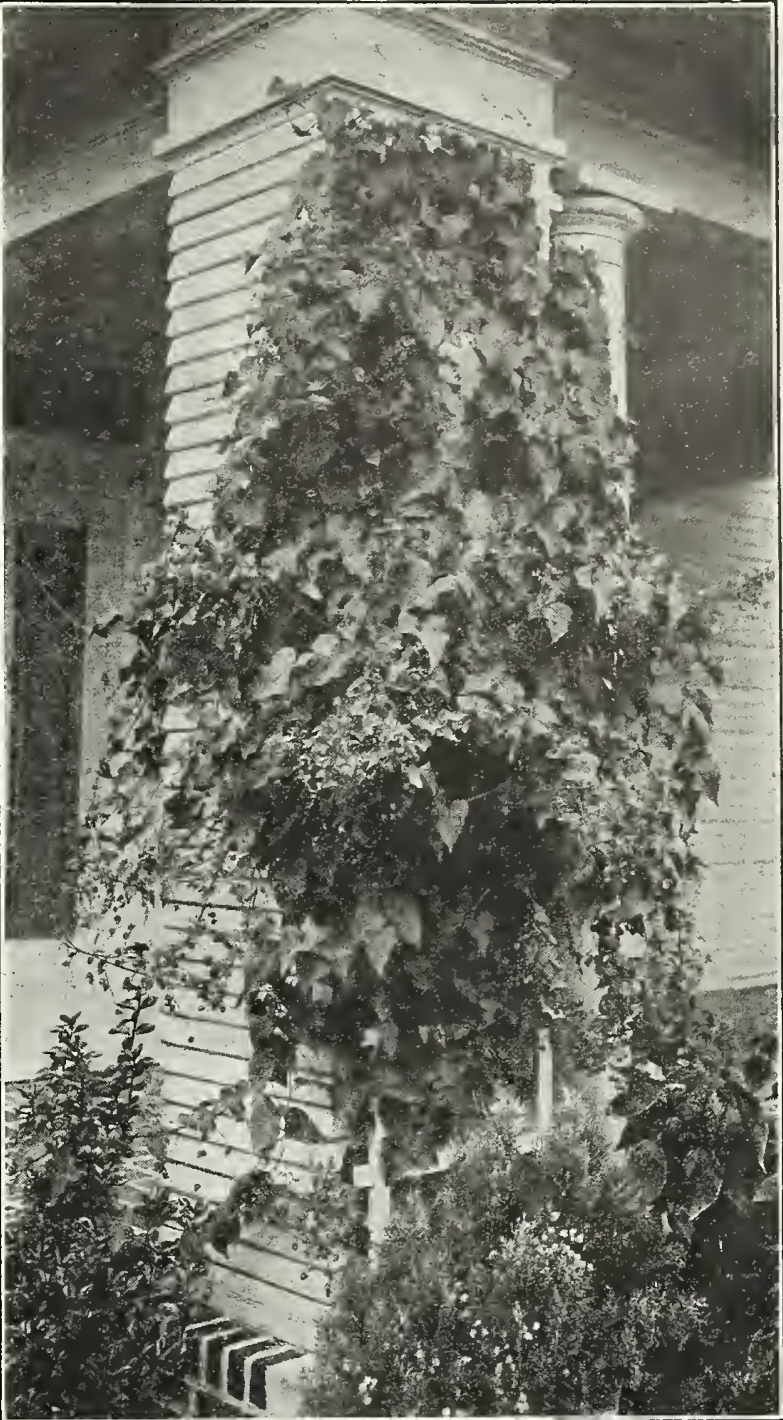

Robinson's Beauty Vine

Famous Japanese Kudzu Vine (Jack-and-thevine that will grow everywhere. Flourishes where nothing else will grow, and lasts for many years. The large bold leaves of the brightest green afford a dense shade. Its greatest feature is its wonderfully strong growth, which makes it invaluable for covering arbors, fences, porches, dead or old trees, etc. The Kudzu Vine is a native of Japan, where it is grown not only for the beauty of the plant, but also for the edible value of its roots. The vine is hardy, grows 50 feet, with dense foliage to the ground. Strong roots $25 \mathrm{c}, 3$ for $65 \mathrm{c}$, 3-year old roots 50c.

Trumpet Vine For covering unsigh ti places, showy-flowering vine is desired, the Bignonias will be found very useful. The flowers are large, attractive and borne profusely when the plants attain a fair size. Large flowers of orange-red. 40c each, 3 for $\$ 1.10$.

Valuable Free Bulletins An d how to $g$ et As long as the supply lasts you can obtain one or more of the following buleetins free of charge. Address a letter to the U. S. Department of Agriculture, Division of Publication, Washington, D. C. Simply make request for the bulletin by title and number as listed below:

Bulletin No. 643-Blackberry Culture.

Bulletin No. 917-Growing Peaches.

Bulletin No, 1001-Growing Fruit for home use. 

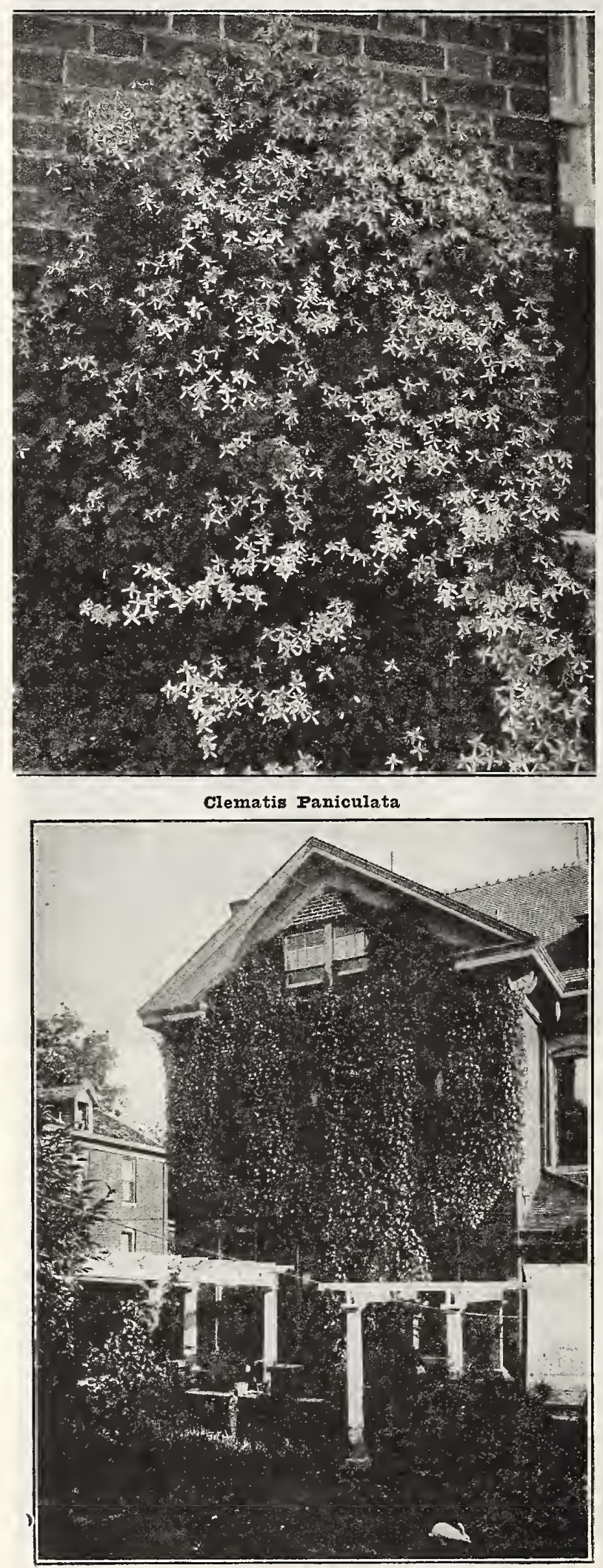

Quinouefolia (Virginia Creeger)

\section{HARDY CLIMBERS-Continued Cinnamon Vine}

This gem of a climber is a marvel of beauty and fragrance. Its rapid growth, abundant foliage and modest, sweet-scented flowers give it supremacy over all other climbers. The handsome, glossy, heart-shaped leaves and clusters of fragrant white flowers, make a veranda or window a bower of beauty. No one should miss planting this beautiful vine. Strong tubers 12c each, 3 for 32c, large size $15 c$.

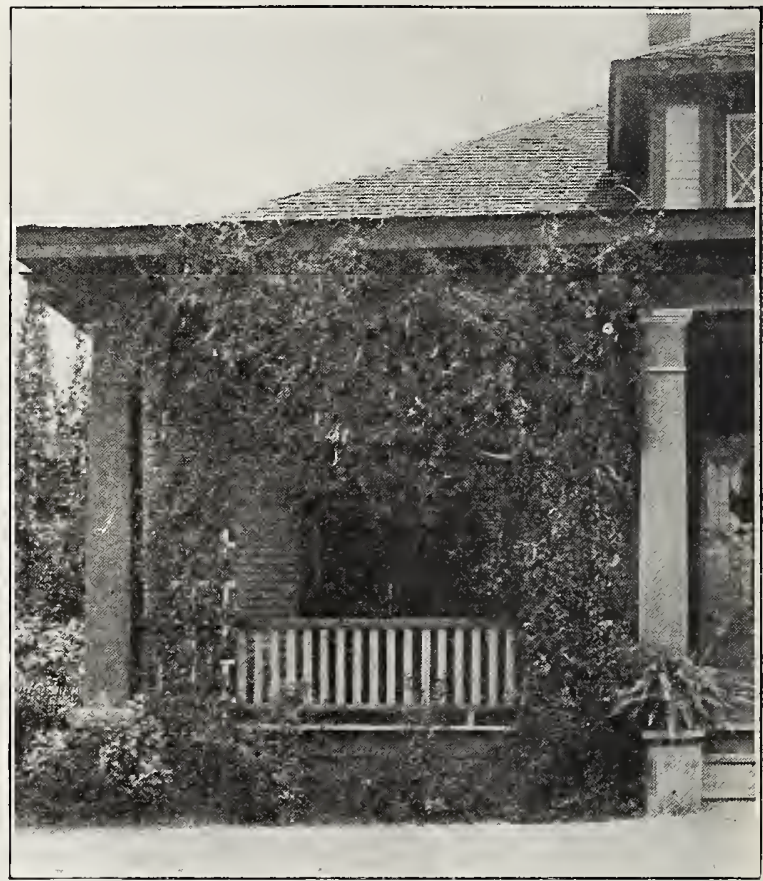

Cinnamon Vine

Clematis A very ornamental class of climbing plants, trellises, arbors, etc. They grow luor training on porches healthy green foliage, and produce an abundance of lovely flowers late in the summer and early fall. Plant them in partially shaded situations, in good, rich garden soil, and give the young plants some support by loosely tying them. Our plants are on their own roots and will give best results under judicious treatment.

Jackmanii Produces great masses of large, rich, velsize, 85c each.

Paniculata Grows very rapidly, soon reaching a aniculata height of 15 to 20 feet. During September e plants present a mass of dainty white flowers, borne in clusters on long stems. The flowers are of a magnolia-like fragrance. One of the most beautiful and satisfactory vines for the South. Large size, $60 \mathrm{c}$ each; second size, $40 \mathrm{c}$ each.

\section{Ivy}

Ampelopsis Quinquefolia (Virginia Creeper)rapid climber, with rich green foliage, changing to bright red in autumn. The foliage is large and not so glossy as the following. When trained over a building, fasten the stem to the wall in some way, or storms will tear them off. Price, each, $40 \mathrm{c}, 3$ for $\$ 1.10$.

Boston Ivy A hardy Ampelopsis of Japanese origin. It grows as rapidly as the old Virginia Creeper, and attains a height of 50 feet. It elings firmly to any wall, tree, etc. The leaves are small on young plants, which at first are of an olive green brownish color, changing to bright scarlet in the autumn. As the plant ac quires age the leaves increase in size. Price, 50c, 3 for $\$ 1.40$. 


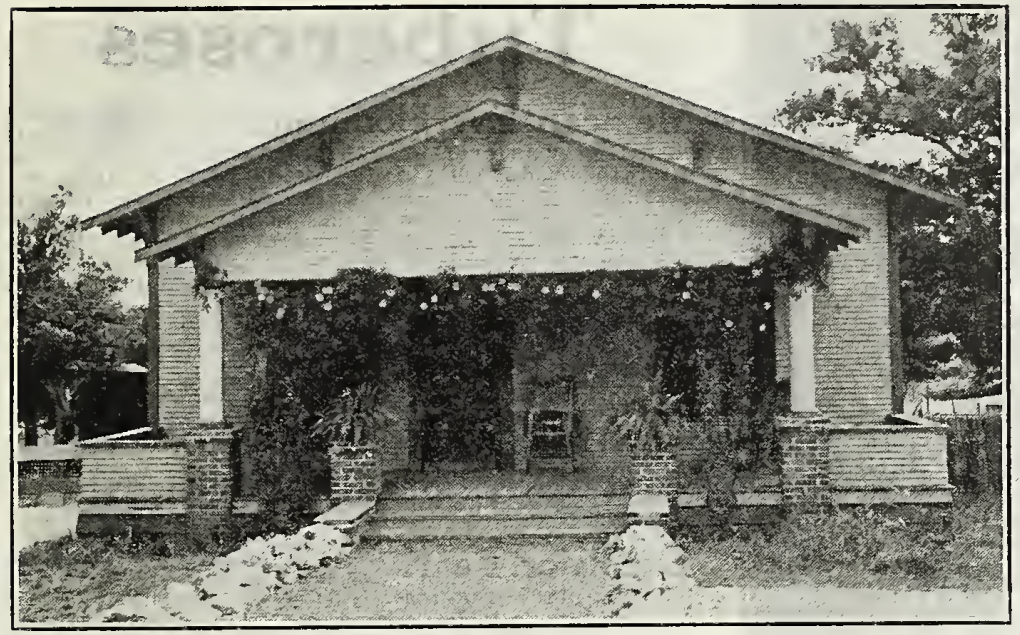

\section{Mexican Morning Glory Vine \\ Elephant's Ear}

(Caladium)

One of the most effective plants in cultivation for beds, borders, or for planting out upon the lawn. To obtain the best results it should be planted where it will obtain plenty of water and an abundance of rich compost. When full size it stands 6 to 10 feet high, and bears immense light-green leaves, 3 to 4 feet long by $2 \frac{1}{2}$ feet wide. Price $35 \mathrm{c}$ each.

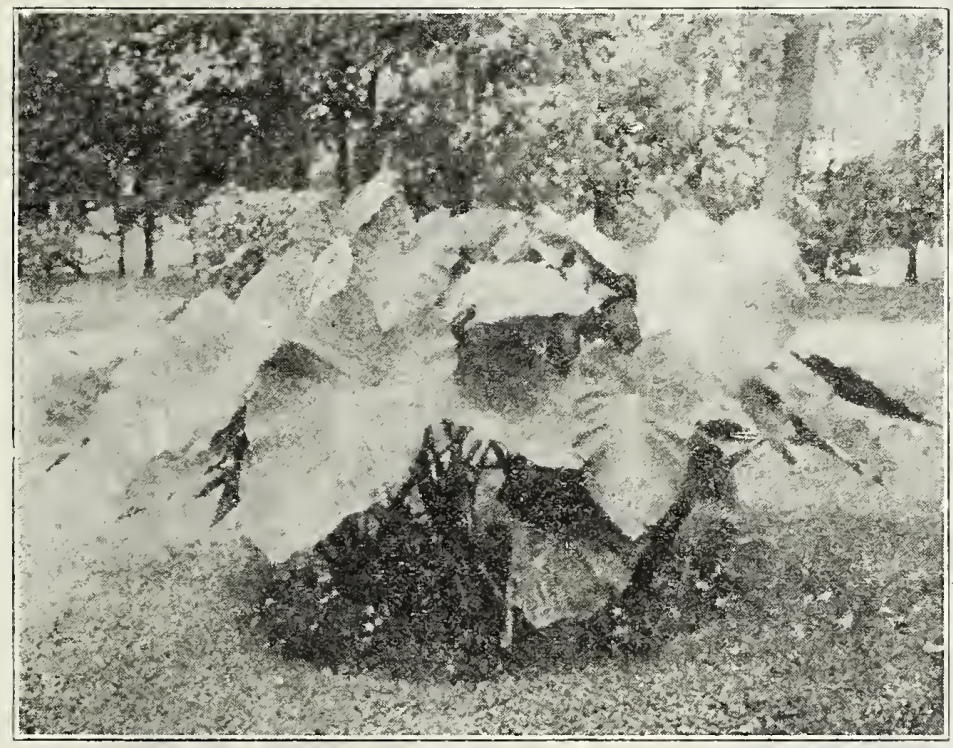

\section{Beautiful Double Dahlias}

(Complete Cultural Directions with Every Order)

Dahlias are so well and favorably known as to require no déscription. No garden is complete without some of these handsome favorit $\in \mathrm{S}$. The Dahlia is a wonderful flower and rivals in popularity any other flower in existence. We offer strong, field grown roots which under favorable conditions will thrive and flourish.

Colors offered were selected from a very complete assortment as the cream of the entire list, for certain characteristics: Uprightness of growth, sturdiness, vigor and general freedom of bloom combined with rich bright or pleasing colors. All are among the finest for cut flowers. Double White, Pink and Red. Price, 500 each, 3 for $\$ 1.48$.

\section{HARDY CLIMBERS-Continued}

\section{Beautiful Mexican Morning}

Glory A rapidly growing vine from Mex. ing arbors, verandas, porches, etc. It succeeds in almost any position, bearing fine clusters of large, purplish rose colored flowers in profusion.

We cannot recommend too highly this beautiful, free blooming, quick growing vine. For best results cover roots with a small quantity of straw or fertilizer during the winter months. Price, 25c each, 3 for $70 c$, dozen $\$ 2.60$, postpaid.

\section{Summer Flowering Bulbs}

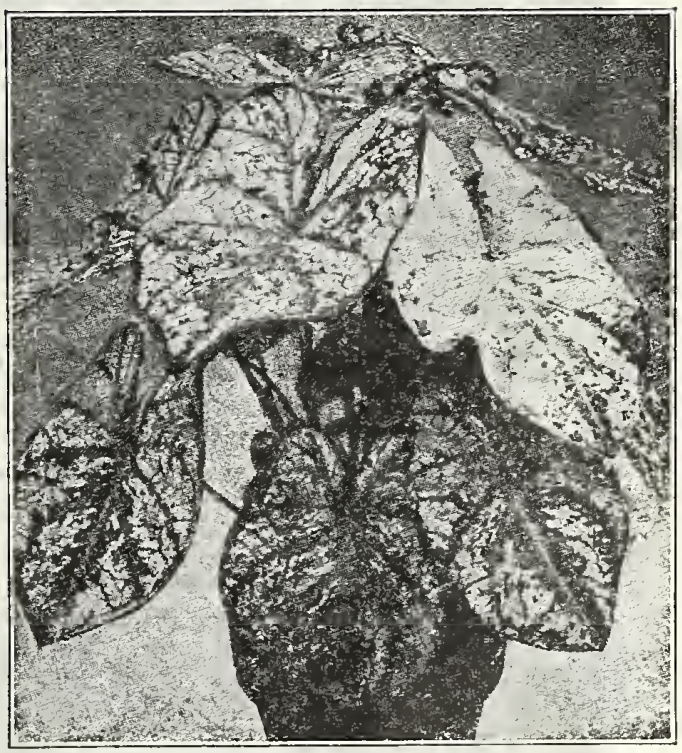

Fancy-Ieafed Caladiums

\section{Fancy-Leafed Elephant's Ear}

No other summer foliage plant equals the Fancy Caladiums in rich and gorgeous, yet soft coloring. All of the varieties are of marvelous beauty for the furnishing of the conservatory during the summer months, for window boxes, or even for outdoor bedding in shady or semi-shady positions. Price, 35c each, 3 for $\$ 1.00$, 


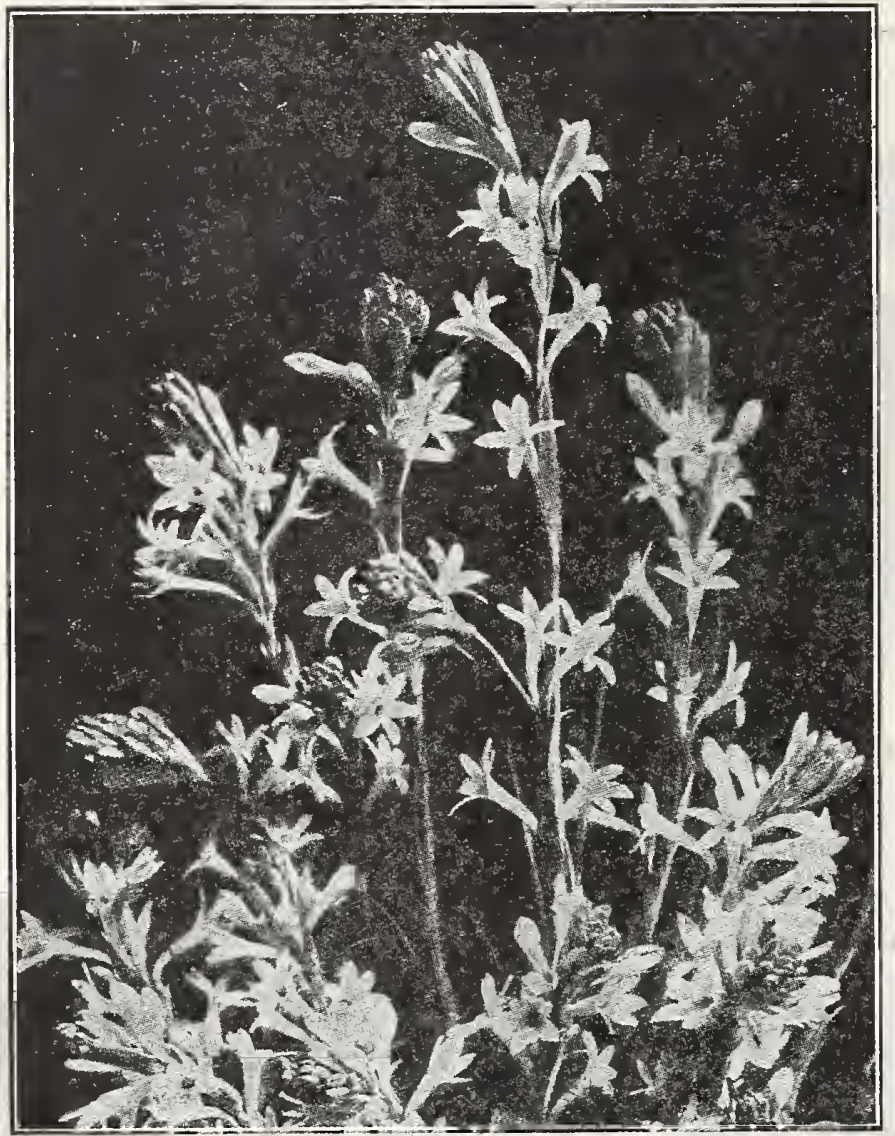

Mexican Everblooming Tuberoses

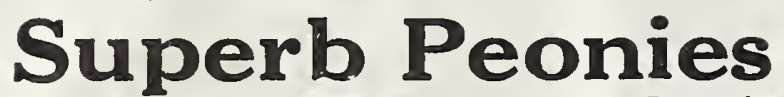

Hardy as the Oak-Once Planted All Is Done-Increasing in

Chinese Peonies are very desirable on account of their large size, fine colors and profuse blooming. They are perfectly hardy, and will succeed in any ground unless so wet that the water will lie on the surface in the winter and spring. May be planted either in the autumn or spring.

Double-White, Pinls and Red. Price, 60c each, 3 for $\$ 1.75$.

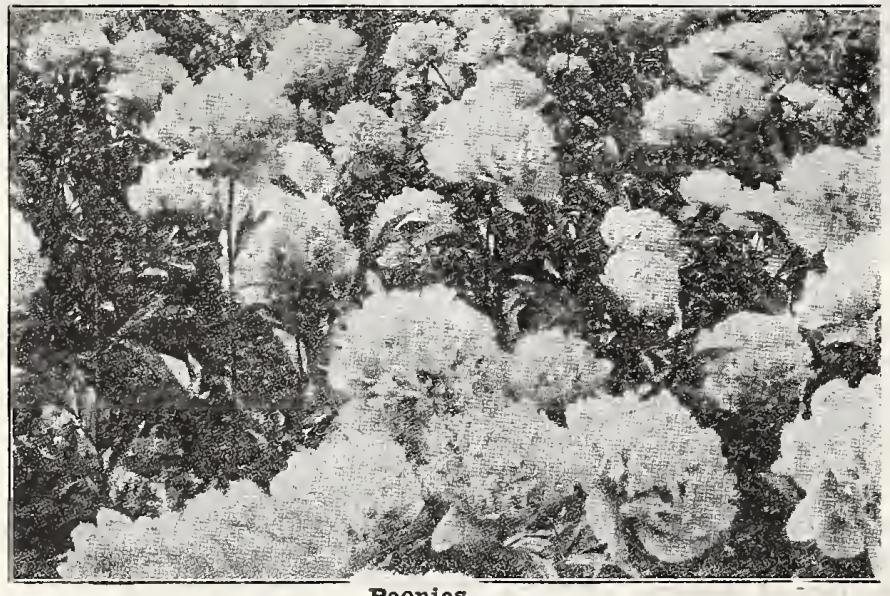

Peonies

\section{Tuberoses}

Mexican Everblooming The most beautirose that was ever brought to our attention Tubegins to produce its fragrant flowers in June and blooms continually until frost. Plant them in good soil and water them occasionally during extreme warm weather, and an abundance of lovely flowers will be the reward. In the southern part of the state the bulbs may be left in the ground all winter 6 for $40 \mathrm{c}$, dozen $75 \mathrm{c}$, postpaid.

\section{Variegated Leafed}

The leaves of this variety are distinctly striped with white and green. Each bulb frequently throws up two or more spikes, three to four feet high, with 20 to 40 pure white single flowers, much like orance flowers, with a pleasant perfume. $15 \mathrm{c}$ each, $\$ 1.50$ per dozen, postpaid.

Excelsior Pearl Our M a m m oth Excelsior lection, made for many years of the most dwarf, double and full flowered spikes, and is exceptionally sturdy and dwarf in habit; the highest type of all. Price, 6 for 50c, dozen 90c, postpaid.

\section{Imperial Gladiolus}

These are the most attractive of all summer flowering bulbs, succeeding in any position. They grow in the most luxuriant manner in the South, and should be in every garden. We have made our price very low so as to place them in reach of the most modest buyer. Plant in open ground February, March and April. Plant 8 inches a part and cover about 3 inches deep.

\section{Gladiolus}

Price, "Rainbow Collection," 25 bulbs, all bright colors, 98c, prepaid. 


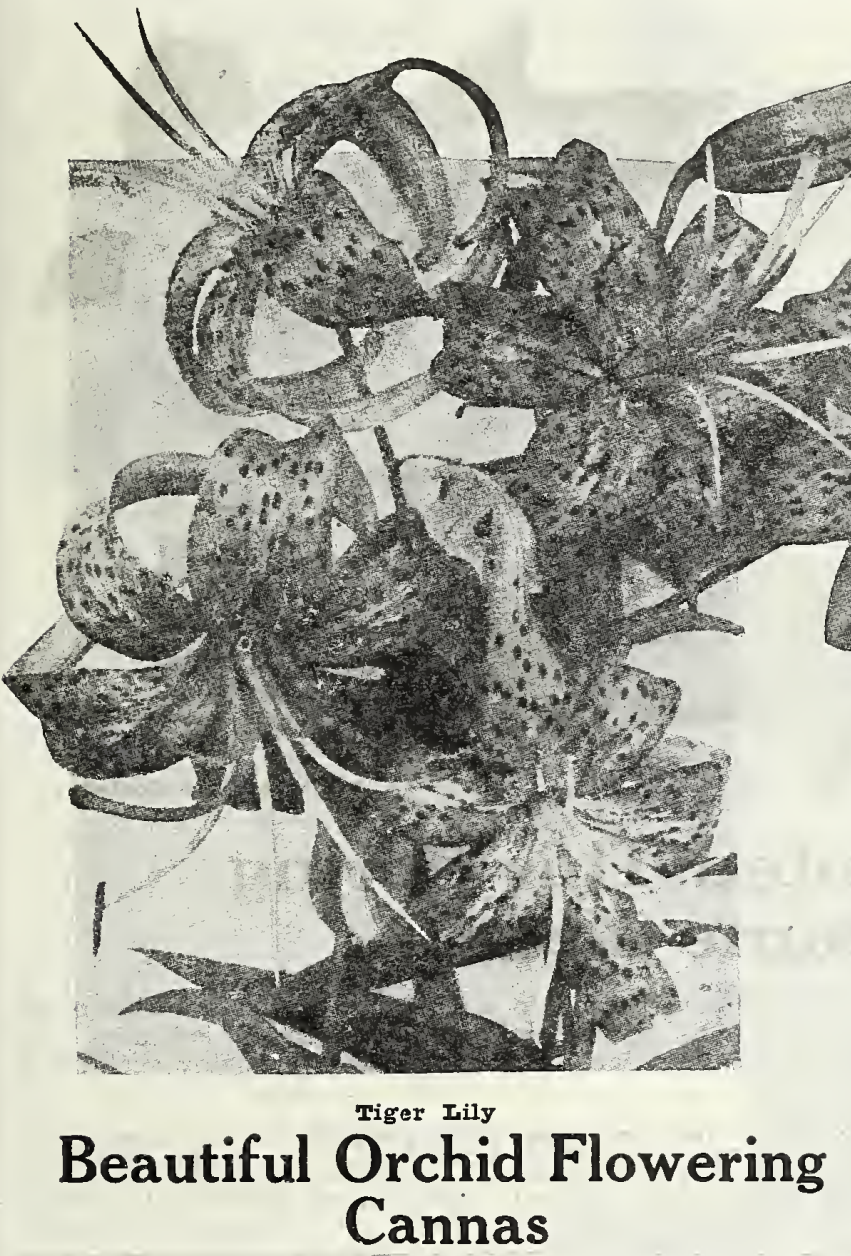

The Canna is the South's most desirable flower. They thrive well in all sections of the country, succeeding in any sunny position in all kinds of soil. Prices, except where noted: $17 \mathrm{c}$ each, 3 for $50 \mathrm{c}, \$ 1.75$ per doz., postpaid.

Milky Way (Green Foliage). Four feet. This variety profectly white bedding Canna. The flowers are large, five to six inches across, with rounded petals of good size, broad and of firm texture. They are borne well above the luxuriant green foliage on erect branching heads in large clusters. The flowers are soft white in color. Price, 35c each, 3 for $\$ 1.00$ prepaid.

Firebird This is in every respect one of the best red flowered Firebird Cannas The petals measure $21 / 2$ inches and more across; the brilliant scarlet without any spots; height, $4 \frac{1}{2} \mathrm{ft}$.

\section{Maiden's Blush}

(Illustrated in color on front cover)

The color of this beautiful new Canna is a glowing salmon pink. The flowers are produced in the greatest profusion on long, erect, branching stalks. It is an early and continuous bloomer, blooming freely in hot or cool weather. It is without a doubt the finest all round salmon pink Canna. Price, 50 c each, 3 for $\$ 1.48$, $\$ 5.70$ per doz.

King Humbert Truly a king among Cannas, because of hanced by its massive truss of coppery scarlet flowers. The foliage is deep bronze, very broad and of wonderful robust habit, growing 4 feet high; splendid as a centre planting, edged with yellow green leaved Cannas or vice versa.

Yellow King Humbert (Queen Helen). This is a bronze-leaved variety, but this sort has green foliage; $41 / 2$ feet high, with masses of golden yellow flowers, dotted red; occasionally some will be streaked red. It is of strong, vigorous habit. Queen of Holland This is really a wonderful Canna and deserves greater prominence than is given to it. $61 / 2$ feet high.
TIGER

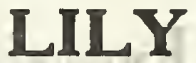

Once the bulbs are planted all is done. The blooms increase in size ard beauty each year.

Tigrinum Splendens

No words can overstate the brilliant beauty of these f a mous Japanese Lilies. The broad petals are thickly dotted with rose or crimson spots, whille the graceful form and brilliant color make them very effective and desirable. Especially hardy. Price, 15c each; 2 for 25 ; $\$ 1.25$ per doz.

\section{RAINBOW}

Gladiolî Collection.

25 Bulbs- $\$ 1.00$ prepaid.

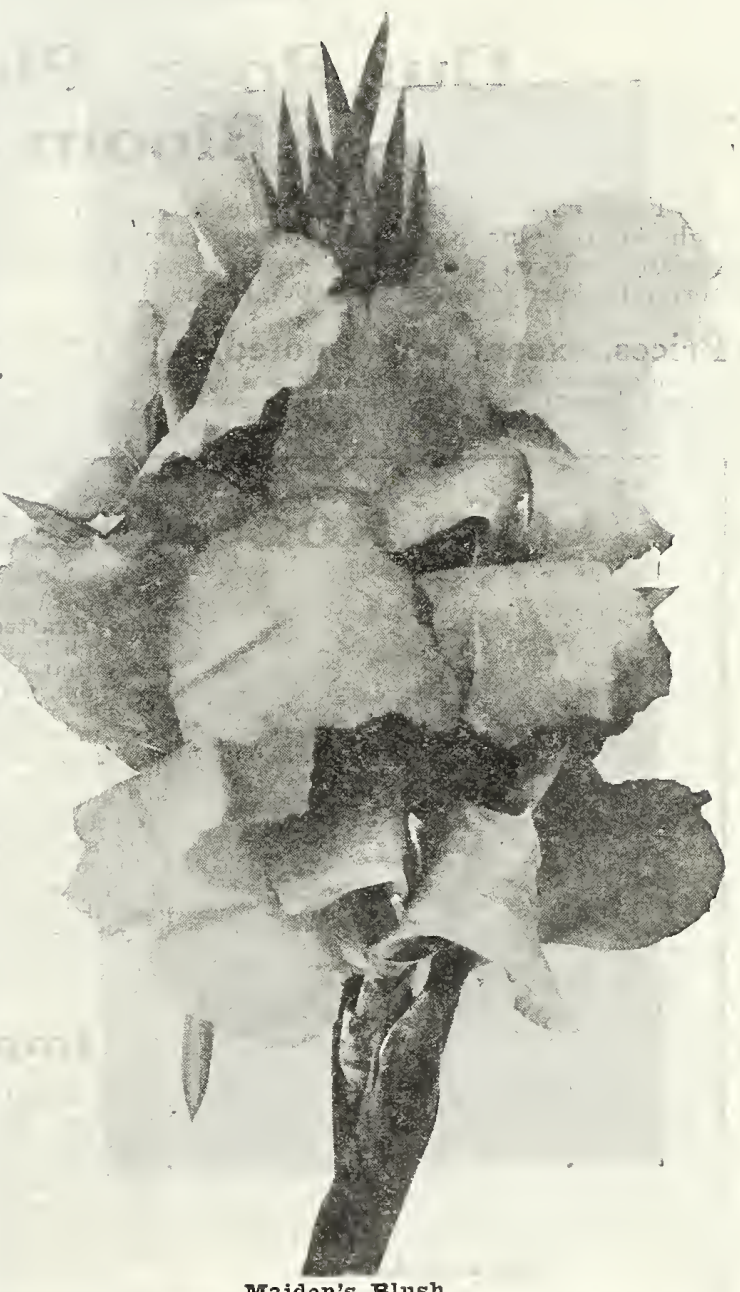




\section{Experience}

\section{the Joy \\ of Having \\ Your \\ Own \\ Roses}

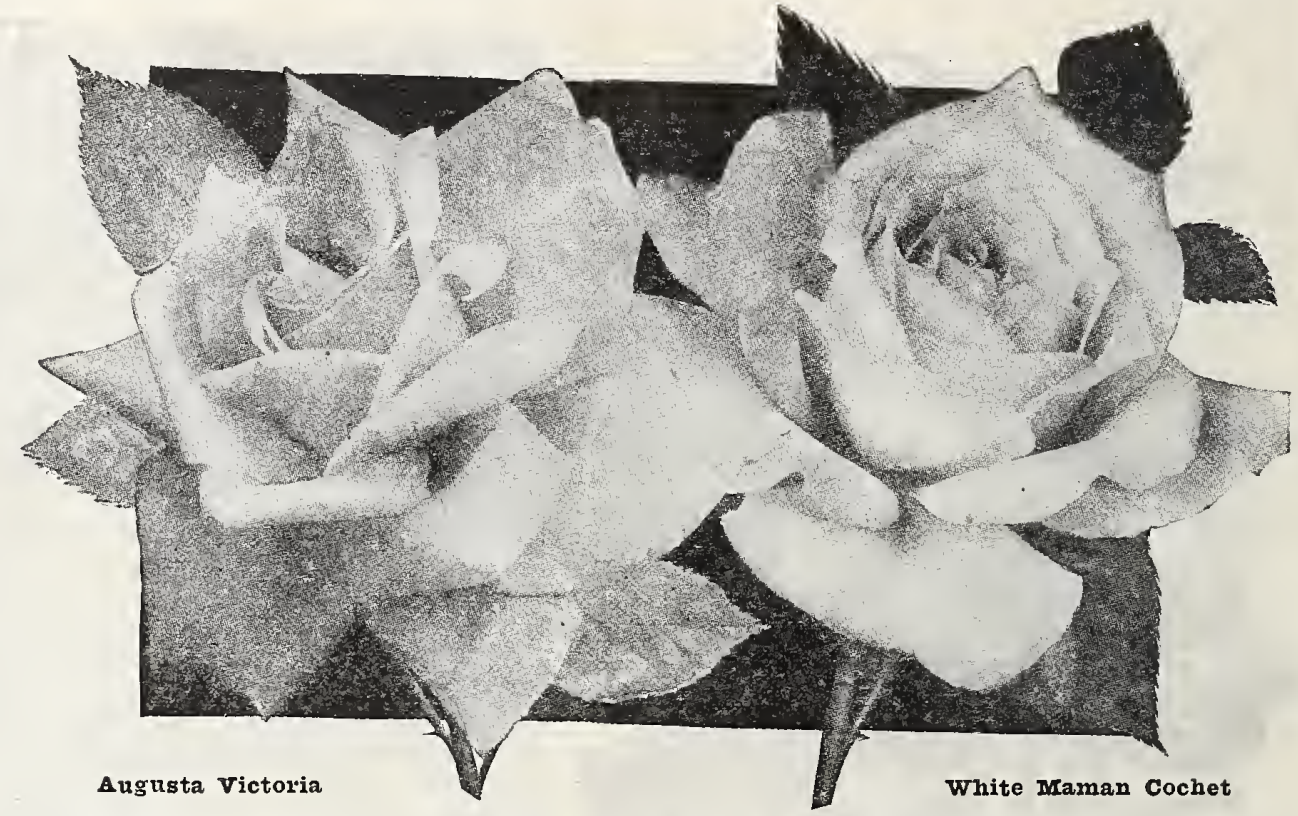

\section{Our Roses Planted This Spring Bloom Same Year}

For years we have been large growers of roses. Folks have learned to depend on us for rose bushes of the right kinds. Our assortment is very complete, as the descriptions on the following pages will indicate. The varieties offered are adapted to spring and winter planting in the open. Our plants are thoroughly acclimated, perfectly hardy and give satisfaction.

Prices, except where noted: 1-year plants, each, 23c, 3 for $65 \mathrm{c}$, dozen $\$ 2.75$, postpaid, 1-year extra heavy treme scarcity of planting stock last year, Field Grown Rose Bushes, are very scarce everywhere; therefore, we cannot supply varieties on the following pages in field-grown plants marked with star( $\star$ ). However, we expect to be able to supply all varieties on the following pages in both 1-year piants and field plants next Fall.

\section{Own Root Roses-Best Kind to Plant}

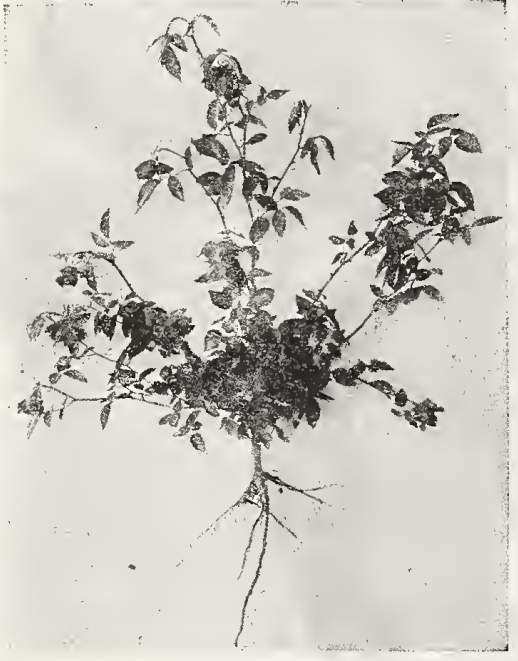

Own Root Roses
If you want the best Roses, don't buy Budded or Grafted Roses. This ty pe of rose seems so much larger and stronger than "own root" roses that one is apt to be deceived into buying them, and you are sure to be disappointed in the result Budded or grafted rose bushes are produced by taking a bud from the original plant and inserting it under the bark of the wild Manettia and binding it thercon. The first year it makes a vigorous growth of soft wood and probably will produce some blooms, but the second year the wild root shoots up wood that produces no blooms and does not even make an ornamental plant, sapping the life from the top, which usually dies. So, we repeat, be sure that you get own root roses, which are the only kind we grow.

\section{Important Notice}

On account of the extreme scarcity of roses this year, we suggest that you give us permission to substitute if ntcessary, giving you varieties equally as good, or better, of the same color as ordered. If/this permission is not granted in space provided for on order blank we will refund purchase price if unable to supply varieties wanted.

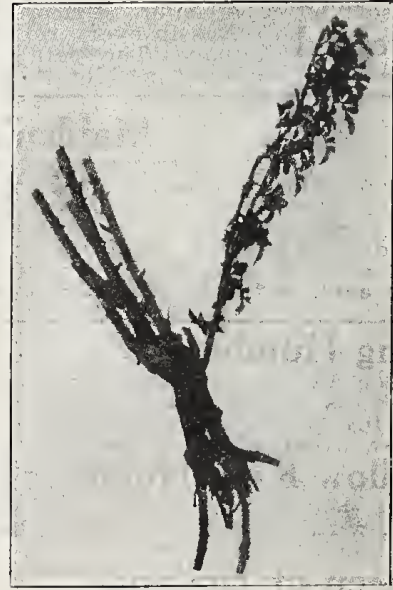

Budded Eose 


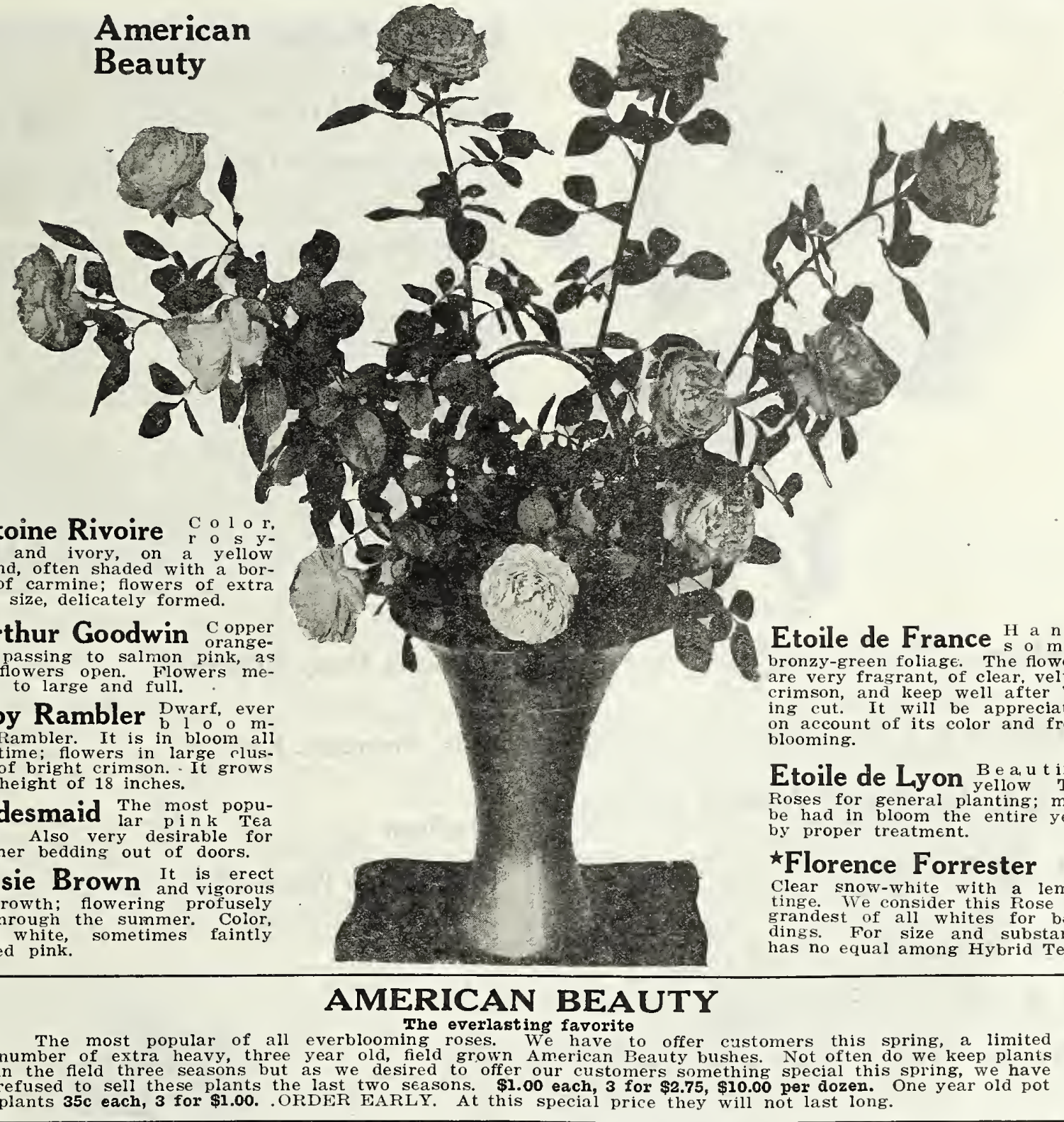

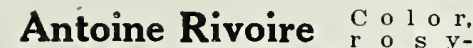
fiesh and ivory, on a yellow ground, often shaded with a border of carmine; flowers of extra large size, delicately formed.

*Arthur Goodwin Copper red, passing to salmon pink the flowers open. Flowers medium to large and full.

Baby Rambler Dwarf, ever ing Rambler. It is in bloom all the time; flowers in large rlusters of bright crimson. - It grows to a height of 18 inches.

Bridesmaid The most popuRose. Also very desirable for summer bedding out of doors.

Bessie Brown It is erect in growth: flowering profusely all through the summer. Color pure white, sometimes faintly flushed pink.

\section{AMERICAN BEAUTY}

The everlasting favorite

The most popular of all everblooming roses. We have to offer customers this spring, a limited number of extra heavy, three year old, field grown American Beauty bushes. Not often do we keep plants refused to sell these plants the last two seasons \$1.00 each 3 for $\$ 275$, 10.00 per dozen. One year old pot plants 35c each, 3 for \$1.00. ORDER EARLY. At this special price they will not last long.

Bride A pure white rose of perfect form and fine size. up beautifully and full; delightfully scented.

Duchess of Albany Also called Red La France. A pink. Superb in every respect.

Clothilde Soupert A strong, dwarf grower and a ducing cluster after cluster of the finest formed flowers. Full and double, and deliciously sweet. The color effect is beautiful-ivory-white shading towards the center to silvery rose.

$\star$ Dean Hole One of the handsomest of the Hybrid with salmon shadings. The coloring is unique.

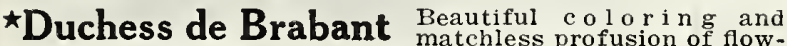
ers and foliage. Soft light rose, with heavy shadings of amber and salmon.
Helen Gould The Sensational Rose. This is probably the most beautiful and satisfactory Rose for general planting ever introduced in America.

Jonkherr J. L. Mock Color, bright, rich pink, strong grower.

Augusta Victoria It is a continuous bloomer, proand flowers and flowers in the greatest profusion. The buds are beautifully formed. Color pure snowy white; very fragrant and a vigorous grower.

Killarney The best known of Hybrid-Teas and is one sparkling of our leading varieties. In color it is a long and pointed, the petals very large and of great sublong and pointed, the petals very large and or great subin the bud form.

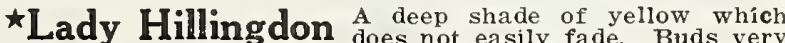
slender and graceful. Very free in the production. of flowers. 


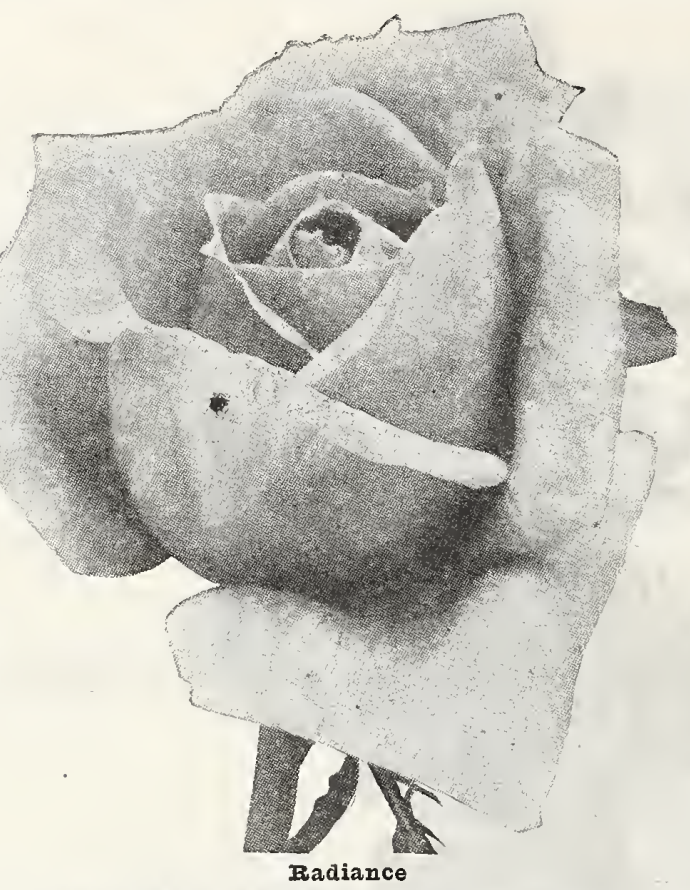

Radiance Gloriously formed flowers, immense in size, Radiance exquisite fragrance, grand foliage, healthy growth, color and freedom of bloom. In color of flower opal and coppery reflections.

$\star$ Wellesley A beautiful pink, the outside of the perals * Wellesley being bright and clear with a silvery reusually fine keeping qualities.

Mrs. Arthur Robert Waddell A delicate soft, fused with a golden sheen; flowers of medium size, especially handsome in half expanded form.

Mrs. B. R. Cant ${ }_{\text {Rose. This variety is remarkable }}^{\text {s. }}$ for its robust habit and the profuse manner in which it blooms. The flowers are of medium size and of a beautiful deep rose color.

*My Maryland A grand cut flower Rose with the larney, but showing a more decided rose-pink.

F. R. Patzer Large, handsome flowers, perfect form and highly tea scented. The color is creamy-buff, the back of the petals being a delicate warm pink.

President Taft $I t$ is without question the most remarkable all pink Roses. It has a shining, intense, deep pink color possessed by no other Rose. It is a fine grower, free bloomer, good size and form, fragrant, and in a class by itself as to color.

* Perle des Jardins Not new, but one of the most beautiful Perle dellow Roses in existence. Makes grand buds, open flowers are extra large, perfectly double and deliciously sweet.

Souv, de Pierre Notting Long budded and fully double a delicate coloring of clear yellow, shaded with apricot and margined in carmine rose.

"Souvenir" De La Malmaison Produces the most pertest weather. Its rich, fresh, flesh pink colored flowers are of immense size, double at the center.

Sumburst A vigorous and healthy Rose, with long pointed buds and splencid flowers, which are produced on strong, upright stems. The color is an intense orange-copper and golden yellow, extremely brilliant in effect.

William R. Smith Creamy white with shadings of pink; foliage; long, stiff stems; vigorous in growth.

* Mme. Constant Soupert A rose of brilliant yellow in are very large and of perfect form, and hold a long time in perfection.

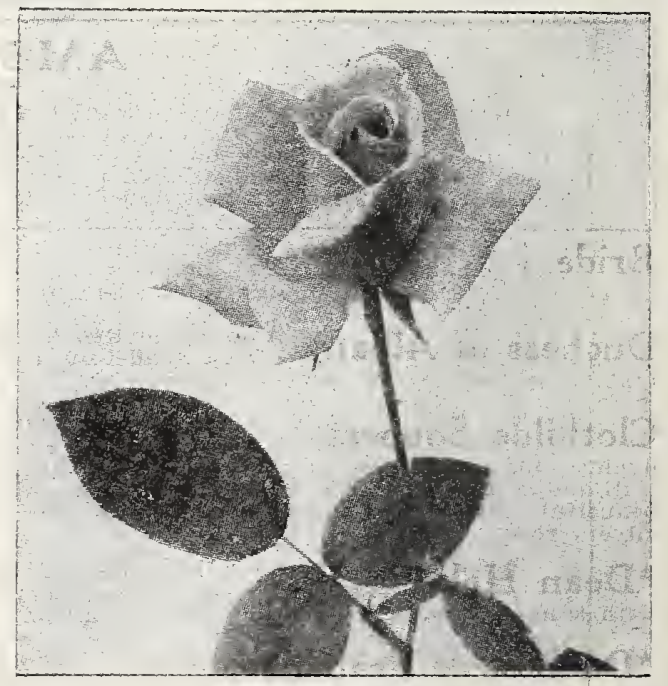

Mrs. Aaron Ward 


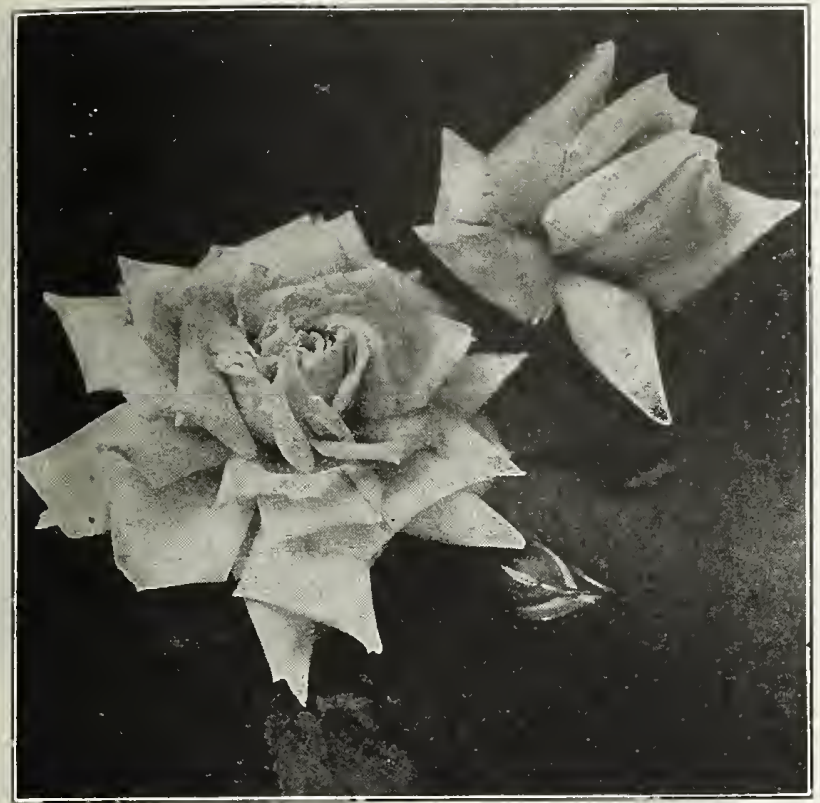

Wnste raman Cochet

White Maman Cochet Very likely to prove the wherever outdoor Roses are grown. Extremely large, rounded and full.

*White Malmaison The color is pure waxy snowhas a lemon tint, just enough to light up and brighten it

\section{Hardy Hybrid Perpetual Roses}

For permanent Outdoor Planting-Selected for Those Who want Roses That Will Stand the Severest Climate and Give Satisfaction in Blooms.

This class of Roses are not everbloomers in the sense that we of the South understand them, but are ercommended for their hardiness and immense fragrant flowers. Ulrich Bruner Rich, glowing scarlet crimson. The and a delightful color. One that is sure to please every Rose lover.

Black Prince Much sought after because of its Black Prince splendid dark crimson flowers, which full, fine shaped.

Dinsmore Constant and profuse bloomer, which Dinsmore begins soon after planting and continues double color, rich erimson scarlet: very showy and handsome, and delightfully fragrant.

General Jacqueminot A celebrated and much Gou so $\mathrm{ght}$ for variety blooms of bright, shining crimson, rich, brilliant, velvety and fragrant. Everybody knows and wants the "Jack" for its all-around good qualities.

Madame Charles Wood Bright, fiery red; a very double, full and fragrant; handsome, showy and a constant bloomer throughout the season. A magnificent and deservedly favorite, hardy variety.

Mme. Masson Bright red; highly perfumed. One and a great favorite.

Paul Neyron We ask special attention to this probably the largest and Rose; the flowers are immense clear and beautiful; very double and full; finely scented blooms the first season. The Rose for home growing: very hardy.
White Baby Rambler Its pure white flowers are bloom with the unceasing freedom of the reds and pinks of this class.

White Killarney A pure white sport of the popular way with its parent, excepting in color, which is pure every

White La France It is identical with La France, except in color, which is pearly the with fawn. One of the most striking and beautiful Roses.

*William Shean Purest pink, petals well shaped, of immense size and substance five inches long; flowers blooming and distinct.

Red Radiance In Ped Radiance we have an exact replica of its prototype, Radiance, except in color and bud. The color is a splendid even shade of clear, red, without a trace of any other color. It is a remarkable bloomer, being constantly in flower. Hardy rerywhele.

Francis Scott Key The New American Rose. The New Amery sarden of every Named in honor of the writer of the Star Spangled Banner. Dazzling crimson, globular Rose of gigantic size.

Richmond Wonderfully free-blooming; its immense fragrant, scarlet-crimson flowers a re Beauty, and even more dazzling in appearance.

Tip Top (Baby Doll) This delightful little ruse is an ever blooming Polyantina I new and quite startling in its brilliancy-Golden Tellow tipved with clear bright Cerise.

Mme. Edouard Herriot (Daily Mail) Bronzy-green foliage. Buds coral-red, shaded with yellow at the base, the open flowers of medium size, semi-double.

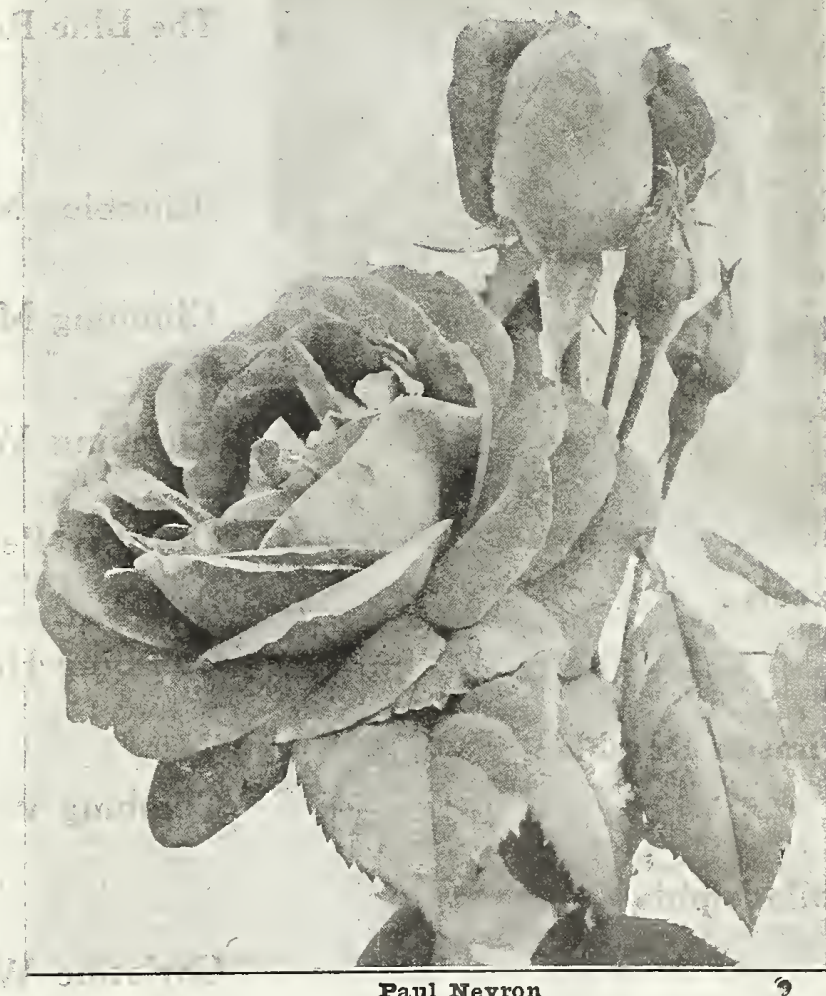




\section{Texseed Own-Root Climbing Roses}

Many new and beautiful varieties have recently been offered in this grand family of roses. luxuriance. Those embraced in the following list are hardy, free blooming and are of a variety of colors. They are nsed in covering trellises and pergolas, for shading verandas and hiding unsightly buildings.

Climbing Kaiserin The greatest of all white climbers. It flowers are extra large, full, deep and double, and are produced on long, stiff. stems throughout the season.

Tausendschon (Thousand Beauties) A Rose prosame bush so many different colored flowers that it is impossible to describe or even picture the variations. Colors run from delicate balsam or tender rose through the intermediate shades of bright rose and carmine, with white, yellow and various other delicate tints showing. A strong grower, impervious against mildew, absolutely hardy. For climbing over porches, single specimens of pyramids, it will please you from the day you plant it.

Climbing Clothilde Soupert New and one of the finest A hardy, everblooming Rose mense bloomer, loaded with large, perfectly double flowers the entire season; color, rich creamy-white, finely tinged with amberrose; deepening center to bright red.

Climbing American Beauty A seedling from American and Tea blood in its veins. Same color, size and fragrance as American Beauty, with the addition of the climbing habit, good foliage and better blooming qualities. One plant of this new rose will produce twenty times as many flowers in June as the old American Beauty, besides blooming occasionally during the summer; blooning 3 to 4 inches across; has proved perfectly hardy and stands heat and drouth as well as any rose in our collection.

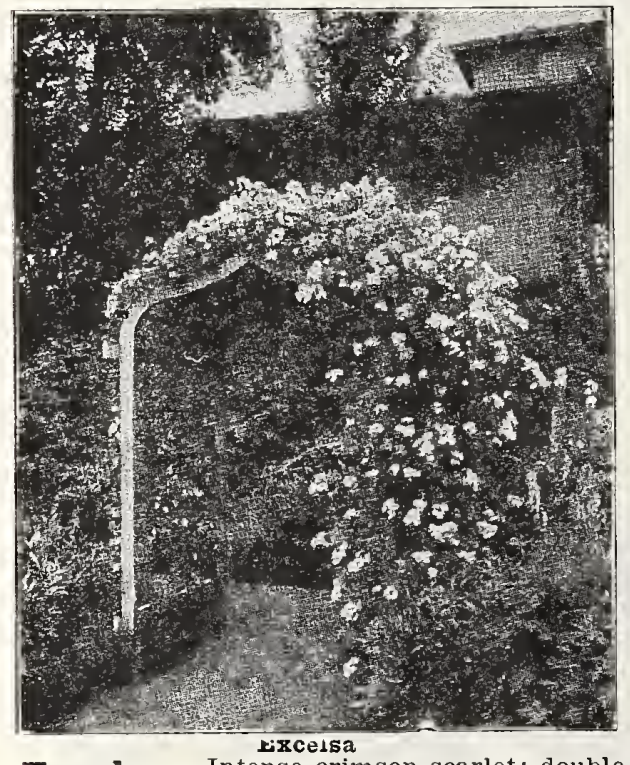

Excelsa Intense crimson-scarlet; double in glossy, shining foliage which never mildews nor spots. An intensifled Crimson Rambler, which it promises to displace. Extremely vigorous and the handsomest of all red climbers.

Crimson Rambler Lovely shade of ceeds everywhere and is particularly hardy. A rapidgrower, making strong, heavy runners 10 to 20 feet long in one season. The flowers are produced in large clusters and are fine for bouquets or decorations of all kinds.

Philadelphia (Hardy June blooming.) and one-half inches across, perfectly double. Borne in clusters, completely covering the whole bush. Color, pure, deep, rich crimson. Unequaled for covering porches, trellises, screens, fences, etc.

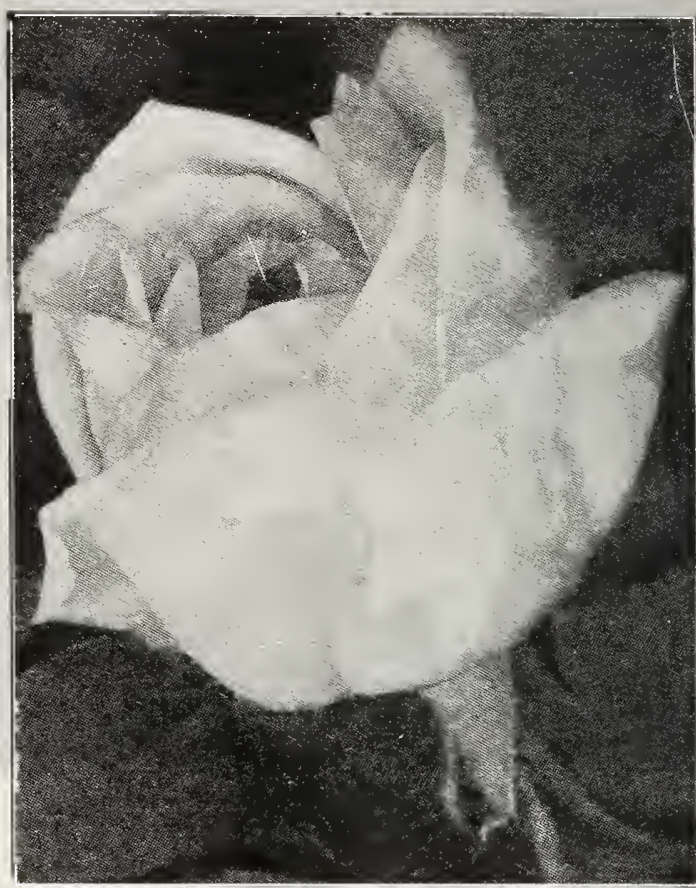

Marechal Nei]

Marechal Neil Deep sulphur-yellow. Very large and extremely istence. Price, 2 year field grown plants, 75c each.

The Blue Rose A new Rose from Holland that originated from of medium size, in large bunches. The originators describe the color as "reddish or rosy lilac when opening, changing to amethyst or metallic blue." We have bloomed it inside and outside and find it as described, and a very distinct novelty. Thoroughly hardy and a vigorous, tallgrowing climber.

*Climbing Malmaison (Climbing Bourbon) A vigorousing form of the old Malmaison.

Climbing Meteor The most perfect red climbing Rose. It is a feet in one season. Blooms freely and persistently and is unequaled for trailing on verandas, porches or around windows, where it will display its beautiful flowers to best advantage.

Climbing Wootton One of the most beautiful hardy, everbloomrich, velvet red, fully equal to General Jacqueminot in color and equally large and beautiful.

Dorothy Perkins This is a grand, new, hardy climber, grows 10 clusters like the Crimson Rambler, but the blooms are more double and of a beautiful shell-pink color, passing to clear, deep rose; makes large, pointed buds and is a very satisfactory Rose.

Climbing Helen Gould Probably no red Rose has held its place secure in the hearts of Rose lovers for pleasure of introducing this famous Rose in climbing form. Everybody is familiar with the warm, watermelon-red color of its charming flowers. This is a grand climber. Be sure and try it.

Climbing White Maman Cochet If there is one Rose that prands out in the affections of the people more than another it is White Maman Cochet. We grow many thousands more plants of White Maman Cochet than any other variety. Here we have a climbing folm that will become as popular as a climber as its parent has as a Bush Rose. Grand, huge, white flowers, tinged pink.

Christine Wright A very strong climbing Rose with large, against mildew or black-spot. The flower is a bright, clear wild-rose pink, $3 \frac{1}{2}$ to 4 inches in diameter, double, borne singly and in clusters. 


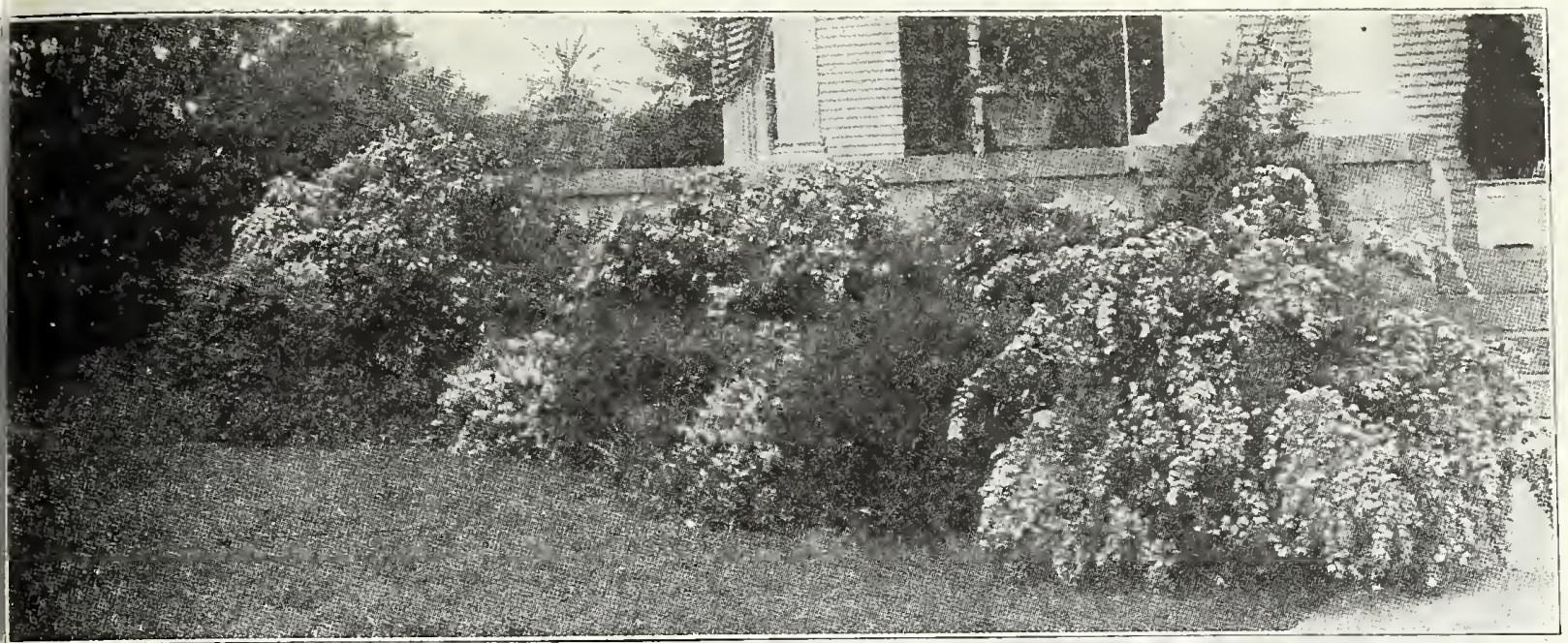

\section{Everyone Admires the Cheerful and Comfortable Appearance That Flowering Shrubs Lend to the Home}

Prices are prepaid. Do not confuse our prices with those who do not prepay. Our plants will cost you less money.

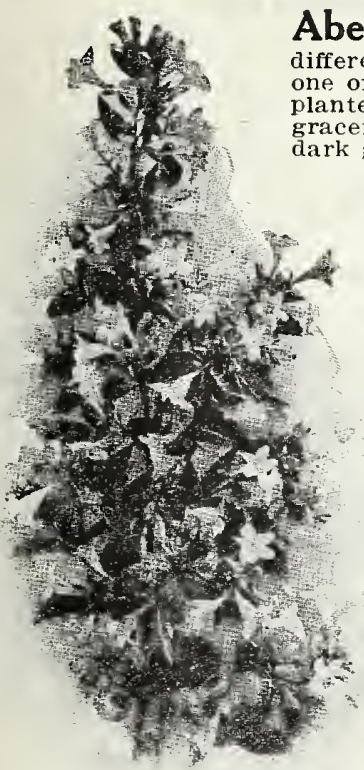

Branch of Abelia
Abelia Grandiflora Af te r thordifferent sections of the South we find this pe our most beautiful evergreens when lanted in a half shaded position. The raceful drooping stems are covered with ark glossy leaves and produce an immense: quantity of tubular shaped white flowers about an inch long, borne in clusters from the midale of May until frost. During the growing season, it is advisable to pinch off the ends of the shootsthis will make the bush dense and compact. This plant is very valuable for single specimens, for groups or for a hedge. Price, prepaid, 90c each, or 3 for $\$ 2.50$.

\section{Buddleia (Butterfly Bush).} tration on front Note colored illusters of large, sweet-scented flowers, measuring 12 to 18 inches in length, closely resembling a lilac in color and general appearance, but continues to bloom all summer in great profusion and unt:1 after the first frost. It is a vigorous growing hardy shrub, and when better known is certain to become as popular as the hardy Hydransea for shrubberies. Without doubt the very best shrub of recent introduction. Price, Pot Plants, $25 \mathrm{c}$ each, $\$ 2.50$ per dozen; large Field Grown Plants, $75 \mathrm{c}$ each.

Althea The flowers are brilliant and striking in color; grows from Altea 9 to 12 feet high when matured. They bloom during August and September, when few other shrubs are in flower; splendid for hedges or single specimens. We can supply fine fleld grown plants in Plnk, Single Red. Price, 60c each, 3 for $\$ 1.75 ; \$ 6.00$ per dozen.

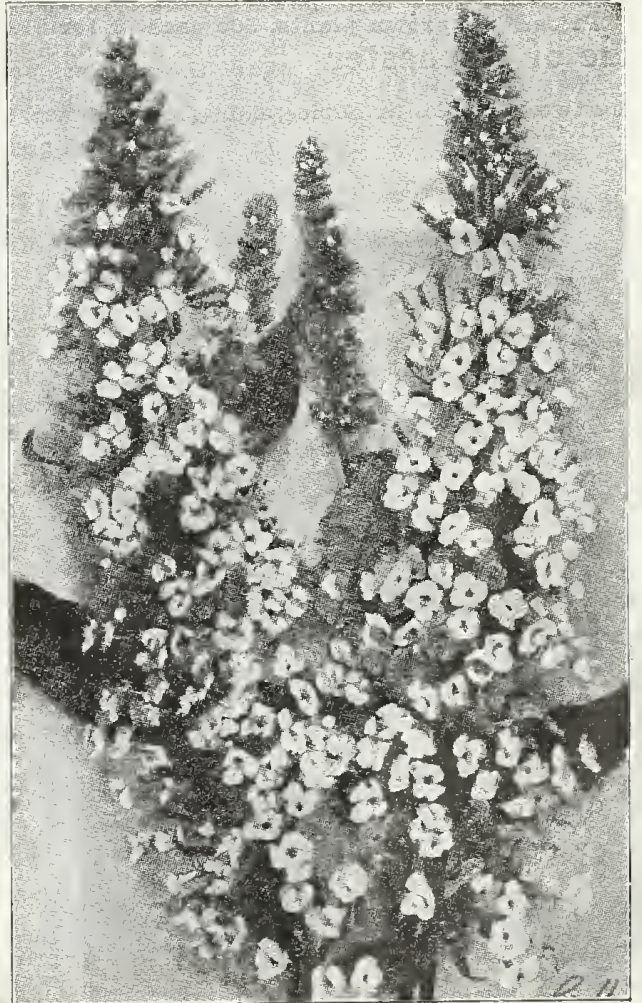

Butterfly Bush 


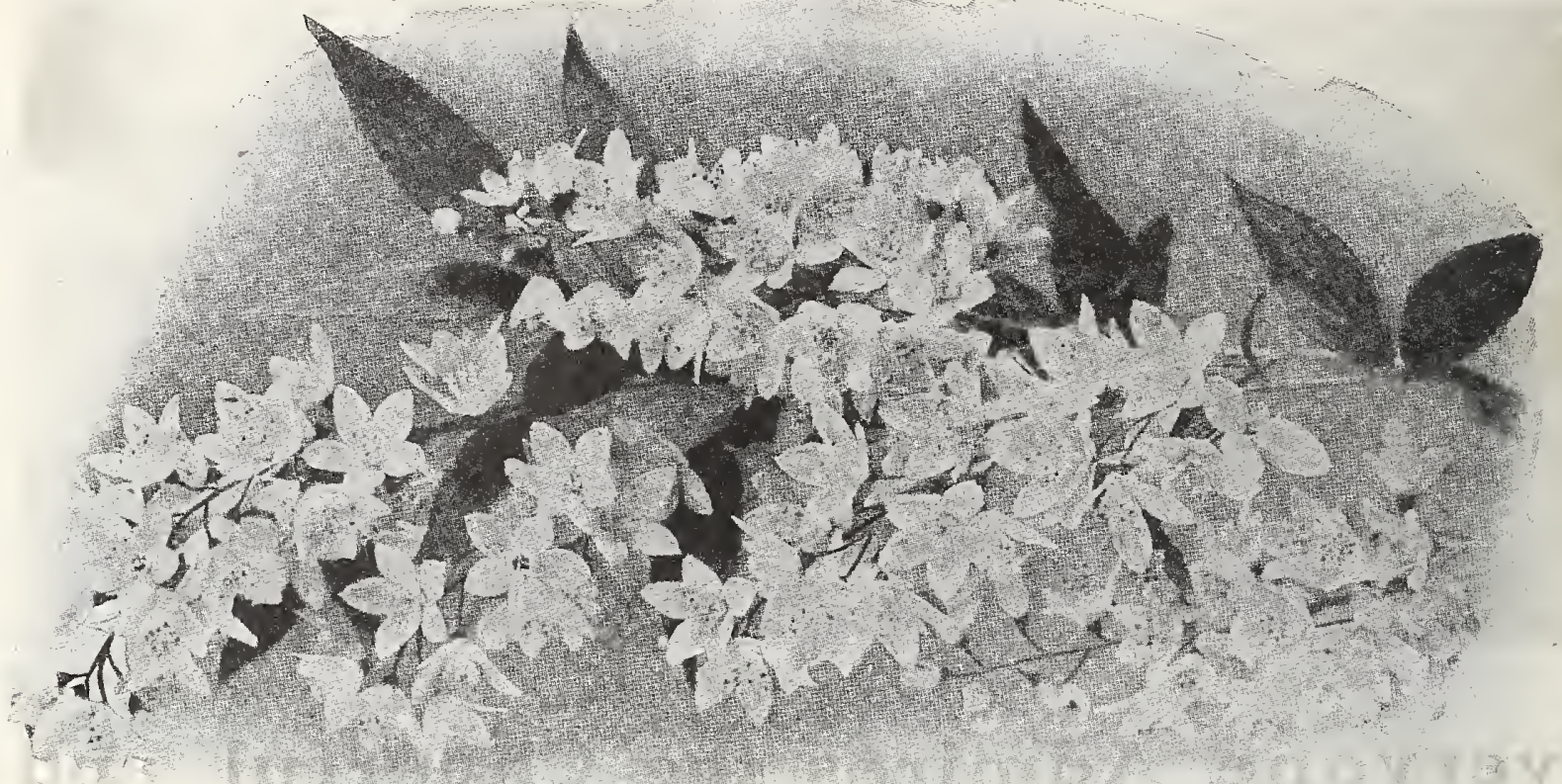

\section{Deutzia}

A showy class of shrubs, especially valuable owing to their compact growth, luxuriant foliage and free flowering qualities.

Crenata Strong, stately grower, attains the height of full. Price, field-grown plants, $50 \mathrm{c}$ each, 3 for $\$ 1.40$.

Pride of Rochester Resembles Crenata, ex cept white, with a faint shade of blush on the outside petals. Strong two-year plants. Price, field-grown plants, 50c each, 3 for $\$ 1.40$.

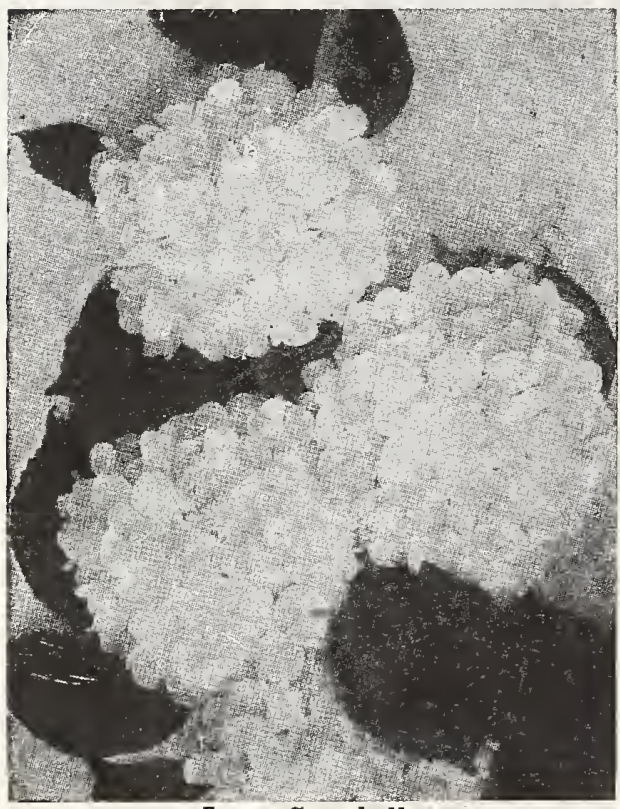

Calycanthus

This is the o l d garden f a vorite, sweet scented $\mathrm{s} h \boldsymbol{r} \mathrm{ub}$. Beautiful foliage with sweet scent$\in d$ flowers, which, held in the hand until warm, give o $\mathrm{ut}$ a most deligh t f u l fragrance. g $x$ o $n$ plants, 60c each, 3 for $\$ 1.75$

Lilac

This is one of the oldtime and deserved l y popular $\mathrm{s} p \mathrm{r}$ i $\mathrm{n}$ flow ering shrubs, deli $g$ h t fully i ragran t purple flowers. We offer ais improved varigrown size, 75 c, 3 for $\$ 2$.

\section{Snow Ball}

Japan Large white flowers. Protect from sun. Price,

\section{Crepe Myrtle}

This beautiful shrub is to the South what the lilac is to the North, only is a more profuse and lasting bloomer, lemaining in flower from early summer until frost. It is hardy as far north as southern Kansas. The flowers bloom in great clusters of delicately fringed panicles. Makes a charmingly beautiful hedge or single specimens. Grows 10 to 15 feet high when fully matured. Every lawn should have this excellent shrub. Red, white, pink, purple. Price, field-grown plants, 60c each, 3 for $\$ 1.75$.

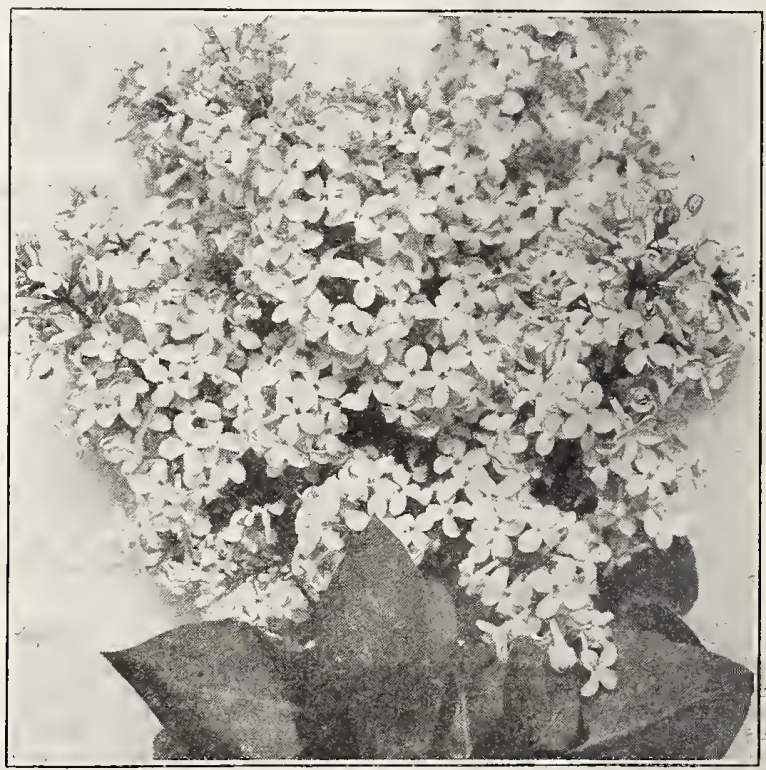

Iilac (Old-Time Favorite) 


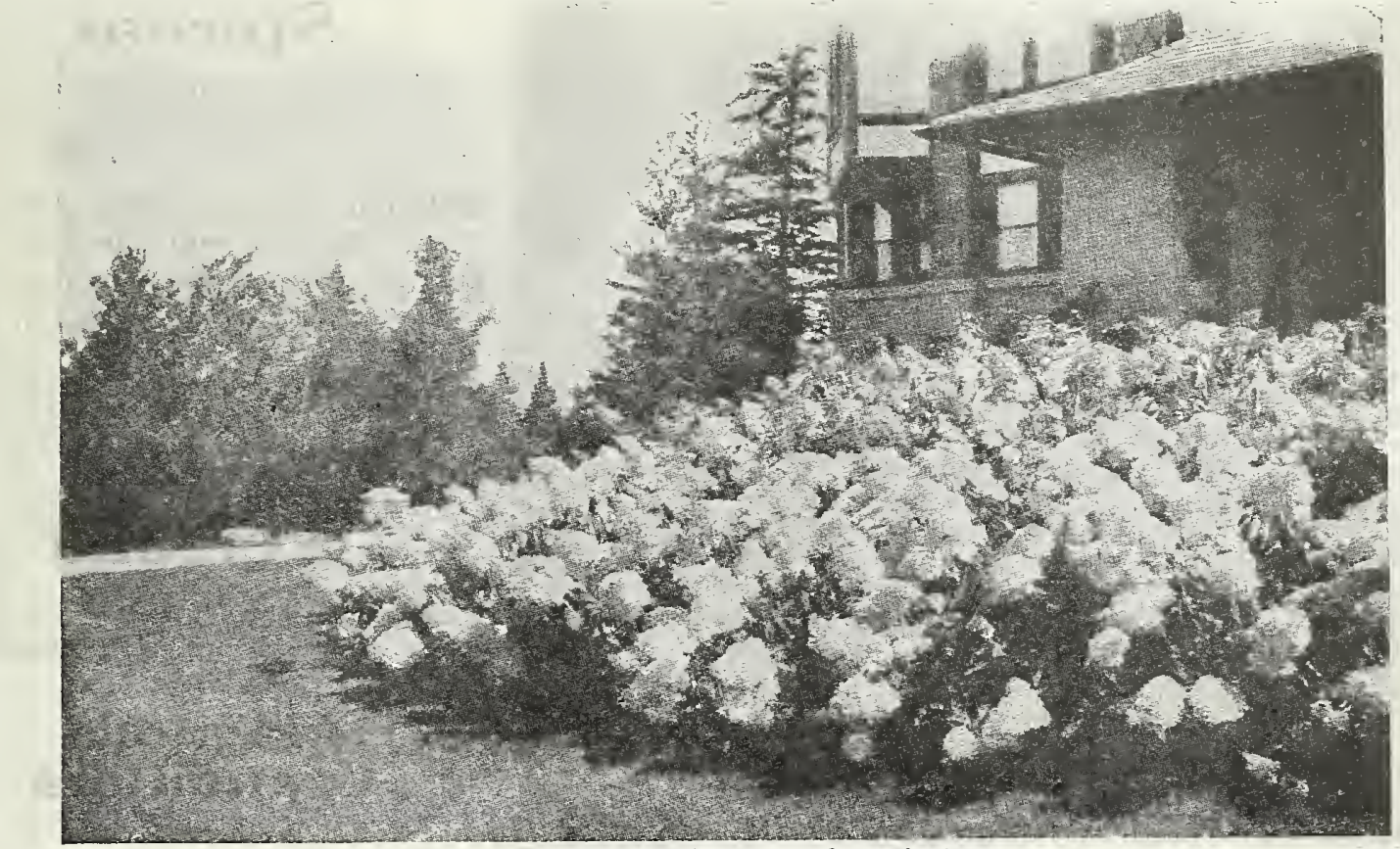

Fydrangeas (New Everblooming)

\section{New, Hardy, Everblooming Hydrangea}

THE NEW EVIRBIOOMING HYDRANGEA is, as its name implies, constantly in bloom. This plant is of recent introduction and is one of the most valuable additions in the way of Hardy Shrubs. The blooms are borne in clusters of immense size of pure white flowers. It will grow to perfection on the north side in a shady position, making it most valuable for massing under trees where other shrubs do not thrive. Price, field-grown, $75 \mathrm{c}$ each or 3 for $\$ 2.00$, prepaid.

\section{Cape Jasmines}

This is an old favorite and the most satisfactory for general culture of all the Jasmines. It flowers nearly all the whole season, and is especially valuable as a house plant in wint e r; flowers st a rshaped pure and very fragrant. Field grow in plants, 60c each, 3 for $\$ 1.75$.

\section{Syringa or Mock Orange} Coronarius A fine old of medium size. Its large white flowers are delightfully scented. Price, fieldgrown plants, 60c each, 3 for $\$ 1.75$.

Grandiflorus $\begin{array}{ccc}\mathrm{T} & \mathrm{h} & \mathrm{e} \\ \mathrm{m} & \mathrm{e} & \mathrm{s} \\ \mathrm{t}\end{array}$ vigorous species in the group. Snow-white flowers. Price, field-grown plants, $60 \mathrm{c}, 3$ for $\$ 1.75$.

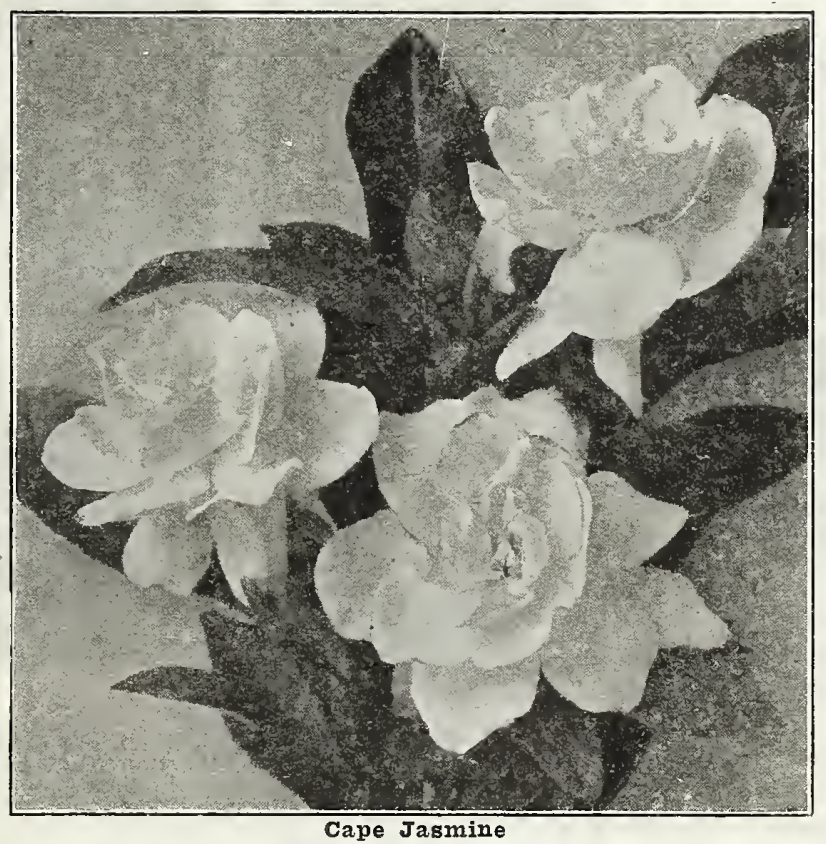

\section{Forsythia (Golden Bell)}

Virdissima

Foliage

d e e p

shining green; flowers bright yellow. A fine, hardy shrub and one of the earliest to flower during the spring. Price, field-grown plants, 60c, 3 for $\$ 1.75$.

\section{Japan Quince}

Bright red flowers which appear on the bush before the foliage is out. A very early bloomer. Valuable for hedges. Price, fieldgrown plants, 60 each, 3 for $\$ 1.75$.

\section{"Butterfly Bush" Wonder Shrub of the South Small Plants 25c Each. Field Grown Plants 75c Each}




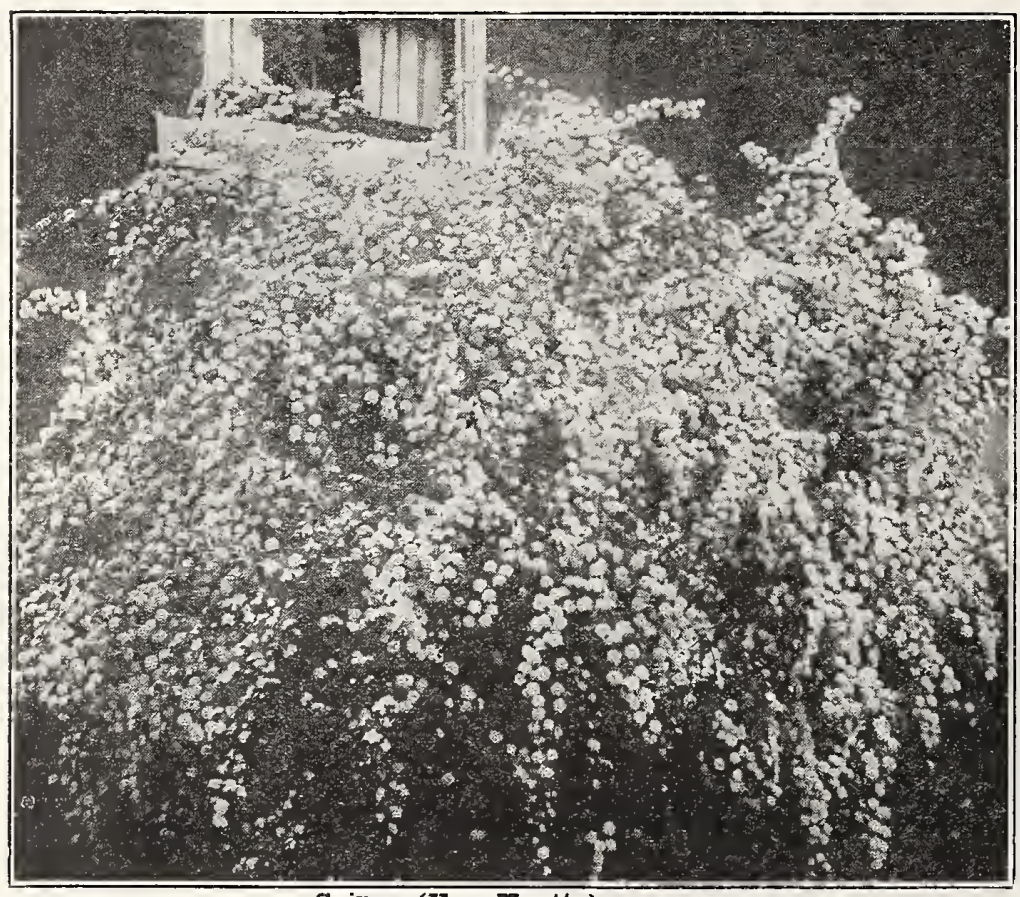

Spirea (Van Foutte)

\section{Hedge Plants}

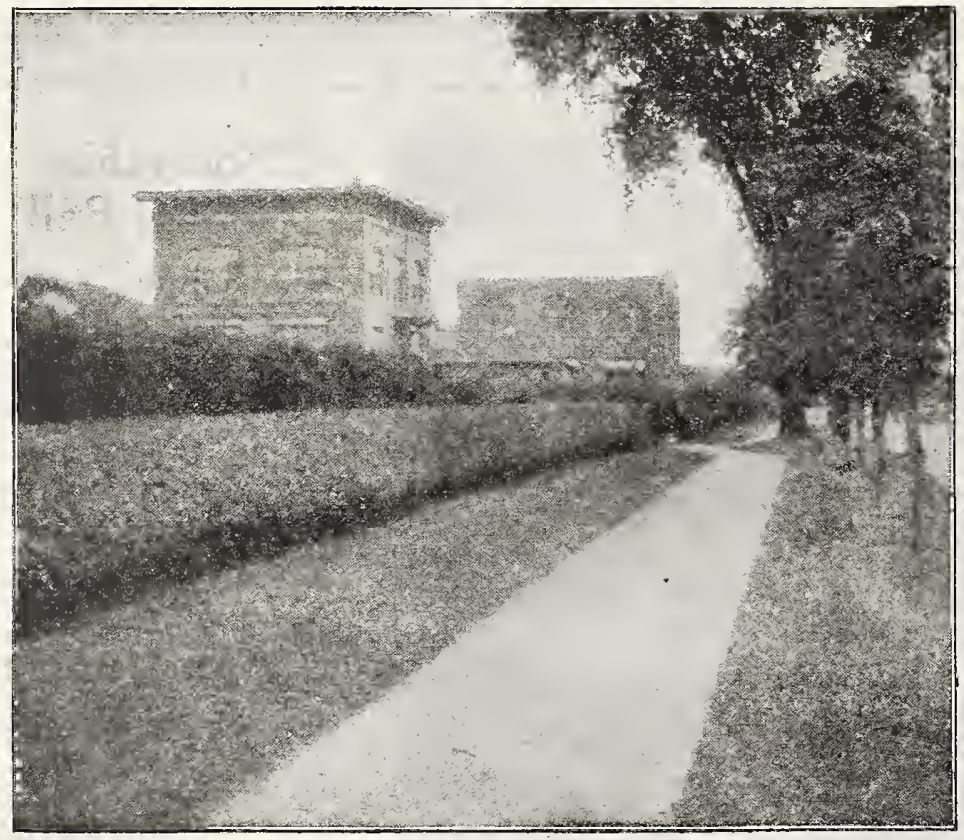

\section{Spireas}

No other class of shrubs embraces a more extensive variety of flowers, follage and habit of growth than Spireas. Hardy and desirable: All field grown plants.

Billardi Fright with dense panicles of August. Pxice, $60 \mathrm{c}$ each, 3 for $\$ 1.70$.

Reeresii (Bxidal Wreath). Double pure 6 feet. As desirable as the snowball. Price 60 ceach, 3 for $\$ 1.70$.

Van Houtte Grandest of all $t h e$ ful, but when in flower a complete fountain of white bloom, the foliage hardly showing. $50 \mathrm{c}$ each, 3 for $\$ 1.40$.

\section{Weigelia}

Candida Very fine light green foliage profusion during June. Frice, fleld -grown plants, $50 \mathrm{c}$ each, 3 for $\$ 1.40$.

\section{Magnolia Grandiflora}

Southern Evergreen Magnolia. The pride of Dixie. Leaves are evergreen, thick and firm; flowers 6 to 8 inches across, pure waxy white, heavily fragrant. We always defoliate before digging to get best results in transplanting. Price, $2 \mathrm{ft}$., $\$ 1.50$ each, 3 for \$4.30, prepaid.

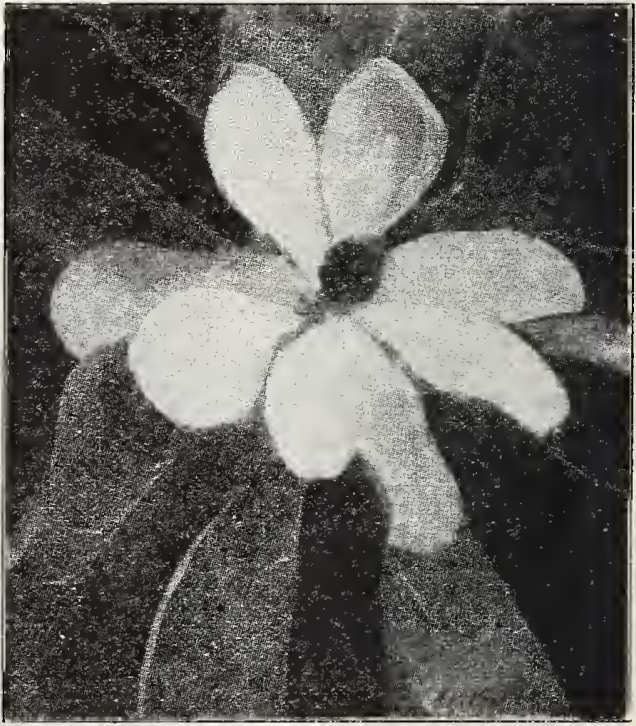

Magnolia

Euonymous Japonica A hardy ornamental plant with rich, handsome foliage, splendid for specimen pot Clif California Privet of the best of all hedges. Also makes fine pot specimens. Pxice, 2 to $3 \mathrm{ft}$., $15 \mathrm{cogch}$, $\$ 1.50$ per dozen, $\$ 9.00$ per 100 , prepaid. Ask for prices on large size.

Evergreen Amoor River South This beautiful new evergreen plant is used for ledges and as an individual prepaid. Ask for prices on larger size.

Dwarf Barberry (B. Thunbergii)-Very attractive, neat and dense in growth, yet graceful because of its on long stems and clinging throuing branches. The yellow flowers are followed by scarlet fruit borne in dense profusion 3 for $\$ 1.10,12$ for $\$ 4.00$, prepaid. 


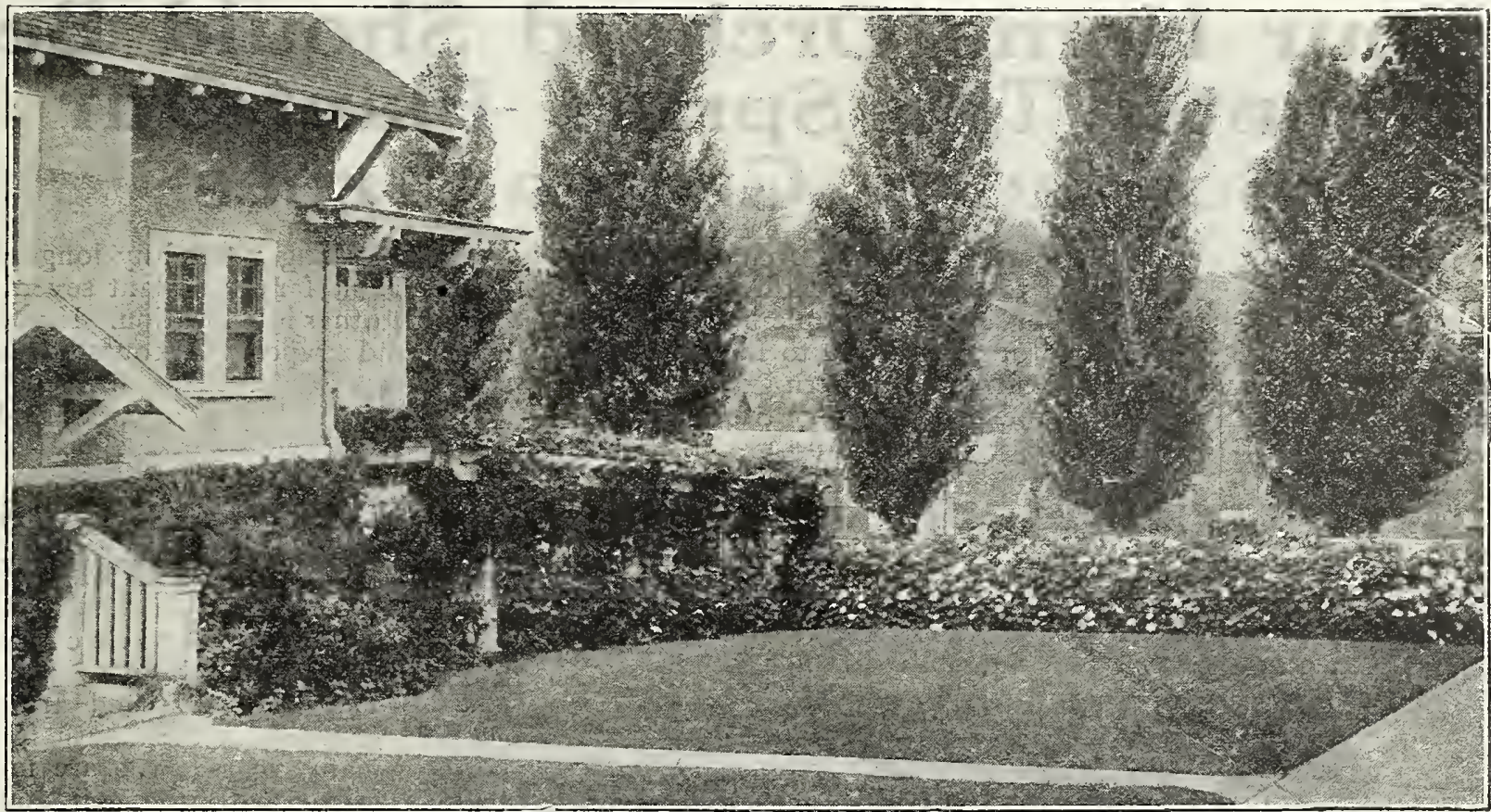

Iombaray Poplar (in Back Ground)

\section{Shade Trees}

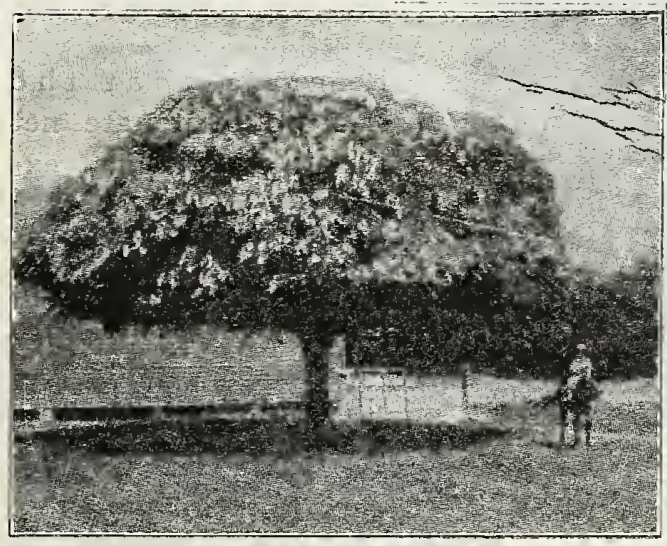

Umbrella China

\section{PRICES ON TREES}

Prices, 4 to $6 \mathrm{ft}$. Prices, to \& ft....

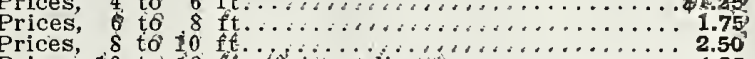

2.50

4.25

special prices on larger sizes upon application.

MOTI-Tránsportation prepaioi on all orders for $\$ 5.00$ or more.

Sycamore Ôríchtal Plane. A lofty, wide-spreading tree, heart shaped leaves; valuable for its hondsome folfage and free growth; not so subject to disease as our native species. En. tirely fres from worms or insects. One of the oldest cultivated trees known. One of the best and most popular for street and sverite planting.

Elfit One of the best known and valuable shade troes. It thrives equally well in cool, shady parks or in cities.

Mulberry, Tea's This tree has a most wonderful drooping and makes a most pleasing addition to the ornamental trees. 2 -ygar heads, $\$ 4.00$.

Mulberry, Non-bearing of these we have the so-called clally adapted to the Southwestern plains country where shade without fruit is desired.
Texas, Umbrella The best tree to grow for all purTex ases. It flourishes in any soil nev never gets too hot nor too dry to prevent its growing rapidly. Especially is it desirable because it is free from borers, scale and disease of all kinds. It will live fron ten to twenty years, and hence should not be depended upon for permanent shade. A good plan is to plant Chinas alternately with sycamores, elms, walnuts, pecans or other permanent trees. The Chinas will make shade at once and do for ten or more years. After this time they once and do for ten or more years. After this time they
may be removed to make room for the permanent trees. which will be growing rapidly and will soon fill up the space. No tree has grown so rapidly into favor during the last four years as the Umbrella China.

Poplar, Carolina One of the most rapid-growing street planting. It is especialy desirable for planting in large cities, as it will stand more hardships than any other tree we know of. The leaves are large, deep green, glossy and handsome.

Poplar, Lombardy $\begin{gathered}\text { An upright grower and valuable } \\ \text { where quick growing is desired. }\end{gathered}$
Ash, Native Well known, leaves dark green, whichy

Box Elder A rapid growing, native trese, Light green landscape work, when contrasted with other whades of green.

Catalpa Speciosa A good tree to plant on sidewall and cattle will not touch it. It is also very ornamental with its large, heart-shaped leaves, and is esprecially handsome when covered with its white and fragresite blossoms in spring. Its timber is very durable, also, résistirg tot for many years. A rapid grower.

Catalpa Bungeii A dwarf variety of the Catálpa eight feet from the ground with a Chinese variety. Use largely as an ornamental tree, being low and with a dense spreading head. 2-year heads, $\$ 4.00$.

Black Locust Especially valuable in the West. shade trees, also for windbreaks. A rapid grower. 


\section{Your Home Orchard Should Be Planted This Spring-Plant Our Southern Grown Trees}

No home or farm is complete without an orchard. Then why delay planting yours any longer? Only a few trees are required to provide enough delicious fruit for the whole family. Plant several trees in front of the chicken house, and a couple back of the barn, or some other idle location. If you live on the farm set aside two or three acres to fruit trees, berry vines, and grapes. Of course, it is most important that you plant strong, Southern grown, acclimated Nursery Stock. The difference in cost to you between good and poor Nursery Stock is very little. It pays to buy good trees and vines, such as we offer.

\section{Fruit Trees, Berry and Grape Vines Always Find Room About the Homes of the Thrifty}

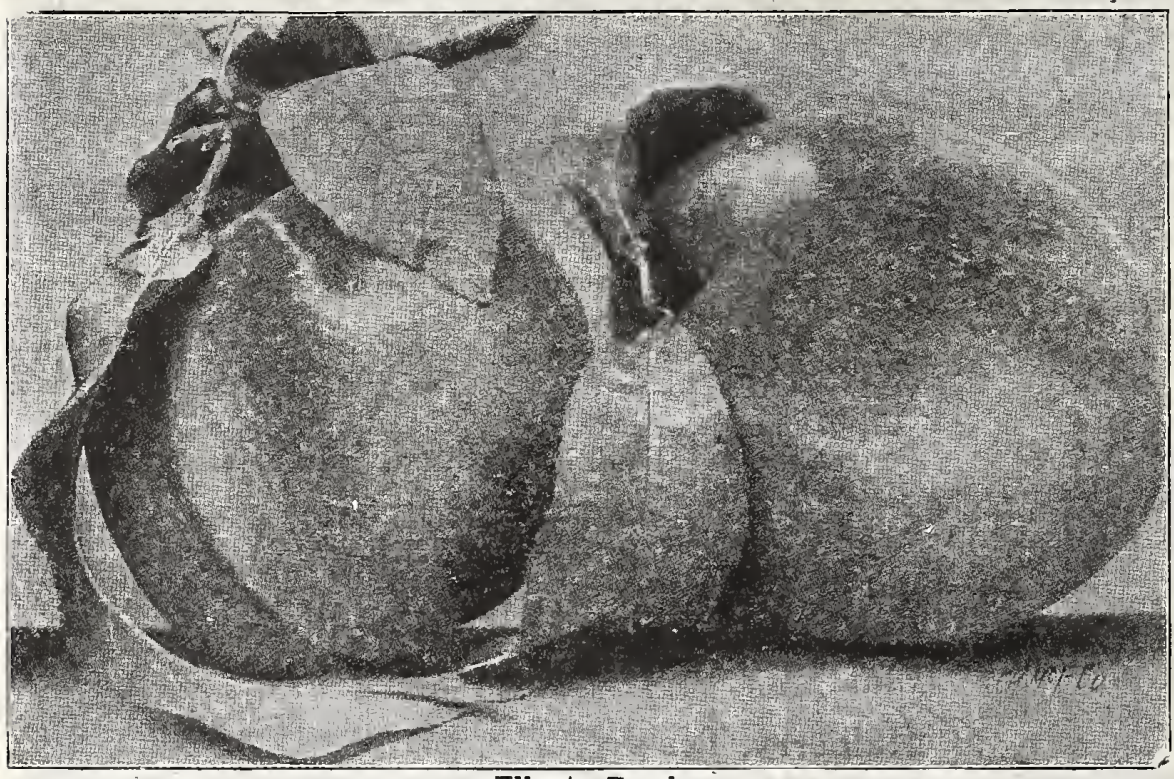

Our experience is worth something to you. We have watched fruit growing in the South for many years. We are familiar with the soil and climatic conditions in all sections. The varie ties listed on the following pages are the best for you to plant.

Remember $t$ hat $t$ he prices we quote are net with all parcel post, express or freight charges prepaid. Also remember that we use every care in packing, so the trees are sure to reach you in good, thrifty condition.

\section{Peaches \\ The South's Favorite Fruit}

PRICES ON PEACHES

Small size, $\$ 0.50$ each; $\$ 5.00$ per doz., prepaid Medium size, .65 each; 6.50 per doz., prepaid Extra large " 1.00 each; 10.00 per doz., prepaid RIPENS MAAY 20 TO JUNE 5

Mayflower This peach is absolutely red all ovei, even ries to market in fine shape and sells well and is the only early peach that is well colored. Inclined to overbear; be thinned.

Triumph The earliest yellow Peach ever known, ripender; of good size, a veraging some larger than Alexandel; very highly colored all over with a yellowish dark red. inaking it a very showy market peach; flesh yellow; good 'fuality, and when fully ripe it parts readily from the pit, which is very small; extremely hardy and a fine shipper. Alexander Larger than Victor, brighter red; semivariety; by testing all we retained the best.

\section{RIPENS JUNE 1 TO JUNE 20}

Mamie Ross Clear white, with red cheek. Flesh size This variety has proven a profitable market peach. Gov. Hogg This is a large white peach with blush 5 cheelis. Flesh white, tender and juicy ant highly flavored. Semi-cling.

Carmen This variety is similar to Mamie Ross, but is nith remarkably fine flavor. Fine market white and Rogers best of its season. Cling. RIPENS JUNE 20 TO JUIY I

Family Favorite Chinese cling crossed with some productive peach. Clear, creamy-white, with rich pink on one side. Flesh-white, tint of red at stone, free, fine quality. Seed medium.

General Lee Skin creamy, one-half next to stem covmuch resembling Chinese Cling. Flesh white, red at stone, cling, excellent quality. Seed rather large. 


\section{Peaches-Continued}

IIPENS JUNY 20 TO JUTY 1

St. John Large, round, oblong: orange-yellow, shaded red. Flesh clear splendid commercial or home peach. Freestone.

Texas King This variety is similar to Mamie Ross, but a better quality. Has very hardy bud, making it a sure bearer. Fully as large and well colored as Carmen. Does well in New Mexico.

\section{RIPENS JUIY 1 TO JUIY 15}

Elberta Too well known to need description. Sure and prolific. Very Flesh firm, Seed large. This is the leading commercial varlety grown in the Southwest.

Chinese Cling Probably the largest peach in cultiration. Skin ing one-third to one-half of surface next stem. Flesh tender, very juicy. A well-known commercial variety.

Chilow A pure yellow cling of the very best quality. Very sweet, Chilow firm, but not tough. Tree a vigorous grower and very pro-
ductive. Cling.

Champion Fruit large, beautiful in appearance; flavor delicious. cheek; treestone.

\section{RIPENS JULY 15 TO AUGUST 15}

Salway Fruit large, yellow with marbled cheek. Flesh market sort. Free.

Stump the World Very large round white, with red good. One of the best late sorts. Free.

Old Mixon Cling Large, skin yellowish white with Old Mixon Cling red cheek. Flesh creamy, white melting, juicy and rich. Highly flavored. Cling.

Indian Cling Large, dark with deep red veins. Flesh ard sort. Clins:

\section{RIPENS AUGUST 15 TO SEPTEMBER 15}

Heath Cling Fruit very large. Skin creamy white and juicy with rich flavor. Cling.
Henrietta The most magnificent yellow eling known Henrietta of largest size, mostly covered with bright crimson, hardy, productive, sure bearer, always commands fancy prices.

White English Large, creamy white with red cheel Juicy and sweet. Quality of the best. home use or orcha
RIPENS OCTOBER

Stinson's October Medium, white with red cheek, profitable pach for late market. Cling.

Bell's Fine Freestone Peach.

Black's October Medium, white, of excellent texbest late peaches cling.

\section{ORDER EARLY}

\section{Apples}

Many orchards in the Southwest are producing valuable crops of apples. The varieties we offer are especially adapted to this climate and should b closely adhered to. No better trees can be offered than those named below. Plant 25 to 30 feet apart, requiring about 120 trees to the acre. On account of sun scald, head apple trees low.

\section{PRICES ON APPIES}

Small size, 50c each, $\$ 5.00$ per doz., prepaid.

Mredium size, 65c each, $\$ 6.50$ per doz., prepaid.

Extra large size, $\$ 1.00$ each, $\$ 10.00$ per doz., prepaid.

Early Harvest Yigorous, abundant. Good for table or cooking. Red June Small, red, prolific. One of the most valuable for heavy Red Astrachan size, medium to large. Bright crimson, covered with white bloom. Good quality. Flesh tender, fine flavor. Summer Queen Ripens in July. Medium to large. Dull red stripes Yellow Transparent Medium size. Tree thrifty. Pale yellow.

Jonathan Good srower. prolific red. Fine for market and table. One Jonathan of the most successful apples grown in the South. Texas Red Especially arlapted to East Texas. Fruit large. Solid reá.

Ben Davis Healthy, vigorous tree and abundant bearer. Fruit large quality.

Winesap Apple

\section{Crab Apples Prices Same as Apples}

Transcendent Crab Fruit is large for its class ful rich crimson cheek, when ripe the red or with a beauticovers the fruit; tree a rapid grower and productive. September.

Red Siberian one of the largest crab apples. Grow cheek. Bears young and abundantly. September. 


\section{Plums}

PRICFS ON PIUMS

Small size, prepaid, $\$ 0.65$ each, $\$ 6.50$ dozen. Medium size, prepaid, $\$ 0.80 \mathrm{each,} \$ 8.00$ dozen.

Extra large size, prepaid, $\$ 1.30$ each, $\$ 13.00$ dozen

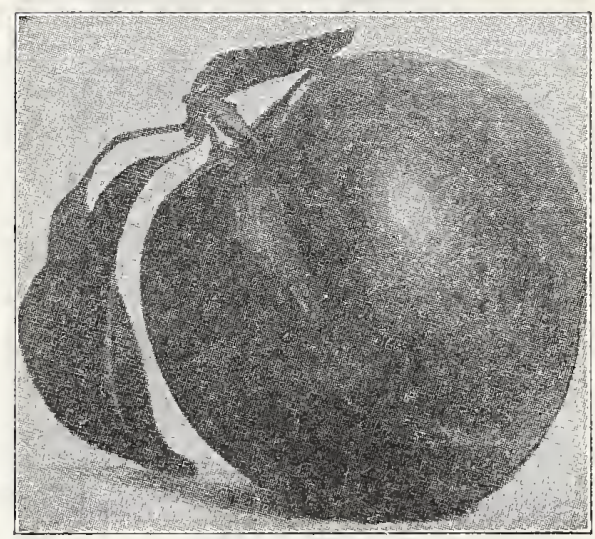

There is no. more valuable fruit crop for the sout hwest than Plums. A good crop is almost a 1 w a y ass u r e d a nd th e y should b e $m$ o $r$ e: ge nerally grown. The c u l t i v a tion and care: of Plums are the $\mathrm{s}$ a $\mathrm{m}$ e as: $\mathrm{P}$ e a ch e s. Plant 15 feet e a c h w a $y$, whi ch $\mathrm{re}$ quires 193: Wickson Flum trees per acre.

Nona A most excellent eating plum. Large, bright red, America Tree very thrifty and symmetrical. Fruit brown with pink cheek. Flesh firm. Stone medium to large. Very valuable. June.

Wickson Lar'ge variety. Slightly heart-shaped. Yeilow blushed with red. Flesh yellow, melting

Eagle Medium, clear yellow, tinged with red, sweet and juicy, valuable for both eating and cooking. Jatter part of June and extends through July.

Wild Goose Large. Deep red. Good quality. One Burbank Large. Clear cherry red. Flesh deep yellow, Bartlett A large crimson plum with flavor similar to Bartlett Barlett pear. An excellent plum. July.

Abundance T'his variety is inclined to overbear and Abundance should be thinned by taking at least onehalf of the fruit off when the size of marbles. Skin yellow, ivashed with purple. Flesh yellow, juicy apricot flavor. July.

Golden Beauty and pleasant, yellow. Flesh firm sure bearer. Trees rather small and with a tendency to overbear. August.

McCartney Large, golden, yellow, egg-shaped, very c. Glowing red, large, meaty and rarely Six Weeks Glowing red, large, meaty and rarely a good grower. June.

Gonzales Fruit very large, meaty, of brilliant red. Very valuable variety. June.

Happiness Extremely large, dark red, quality unTree a good grower and very productive. June.

\section{Cherries}

PRTCES ON CHERTIFS

Small size, \$0.85 each, $\$ 8.50$ dozen.

Medium sizo, $\$ 1.00$ each, $\$ 10.00$ dozen.

Fitra large size, $\$ 1.30$ each, $\$ 13.00$ dozen.

Governor Wood sweet, large, heart-shaped, light good. Tree vigorous.

Baldwin Very large, round, dark, almost transparent: hardy and very prosub-acid

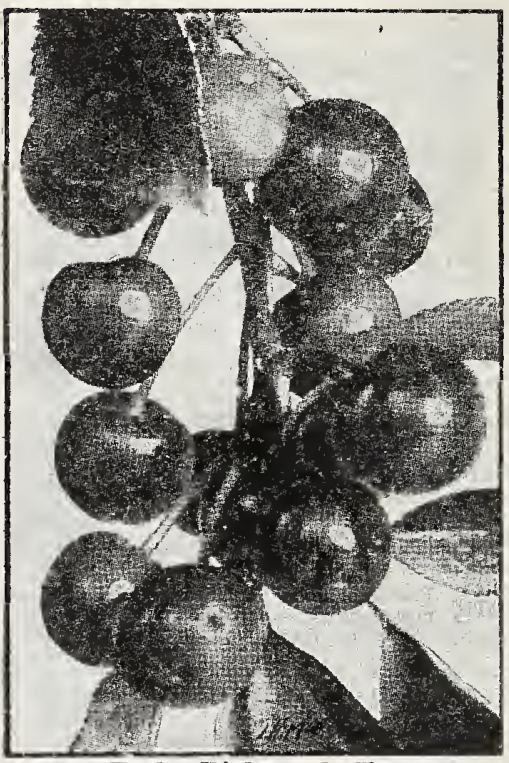

Black Tartarian

Sw e e t, black, juicy, rich, excellent. Very prolific.

\section{Early Richmond}

M e d i u m size, dark red, juicy and rich flavor, hardy and reliable. One sour cherries:.

\section{Montmorency}

Large red, ripening ten days after Early Richmond. Tree slow grower, but prolific. Valuable sour Cherry.

\section{Windsor}

Fruit large, firm and of dark red, flesh fine quality. A valuable late variety.

Early Inichmond Cherry

Yellow Spanish Large, pale yellow, one of the and good.

\section{Valuable Free Bulletins and How to Get Them}

As long as the supply lasts you can obtain the following bulletins free of charge. Address a letter to the U. S. Department of Agriculture, Division of Publication, Washington, D. C. Simply make request for the bulletin by title and number as listed below.

BULLETIN NO. 643-BLACKBERRY CULTURE.

BULLETIN NO. 728-DEWBERRY CULTURE.

\section{Apricots}

On account of crop failure for the last two years we will not be able to supply apricots until next fall.

\section{All Season Peach

We offer in this collection varieties that bear early, medium, and lale. six large trees for \$6.25, prepaid.

$\begin{array}{lll}\text { Mayflower } & \text { Champion } & \text { Henrietta, } \\ \text { Family Favorite } & \text { Indian Cling } & \text { Bell's October }\end{array}$




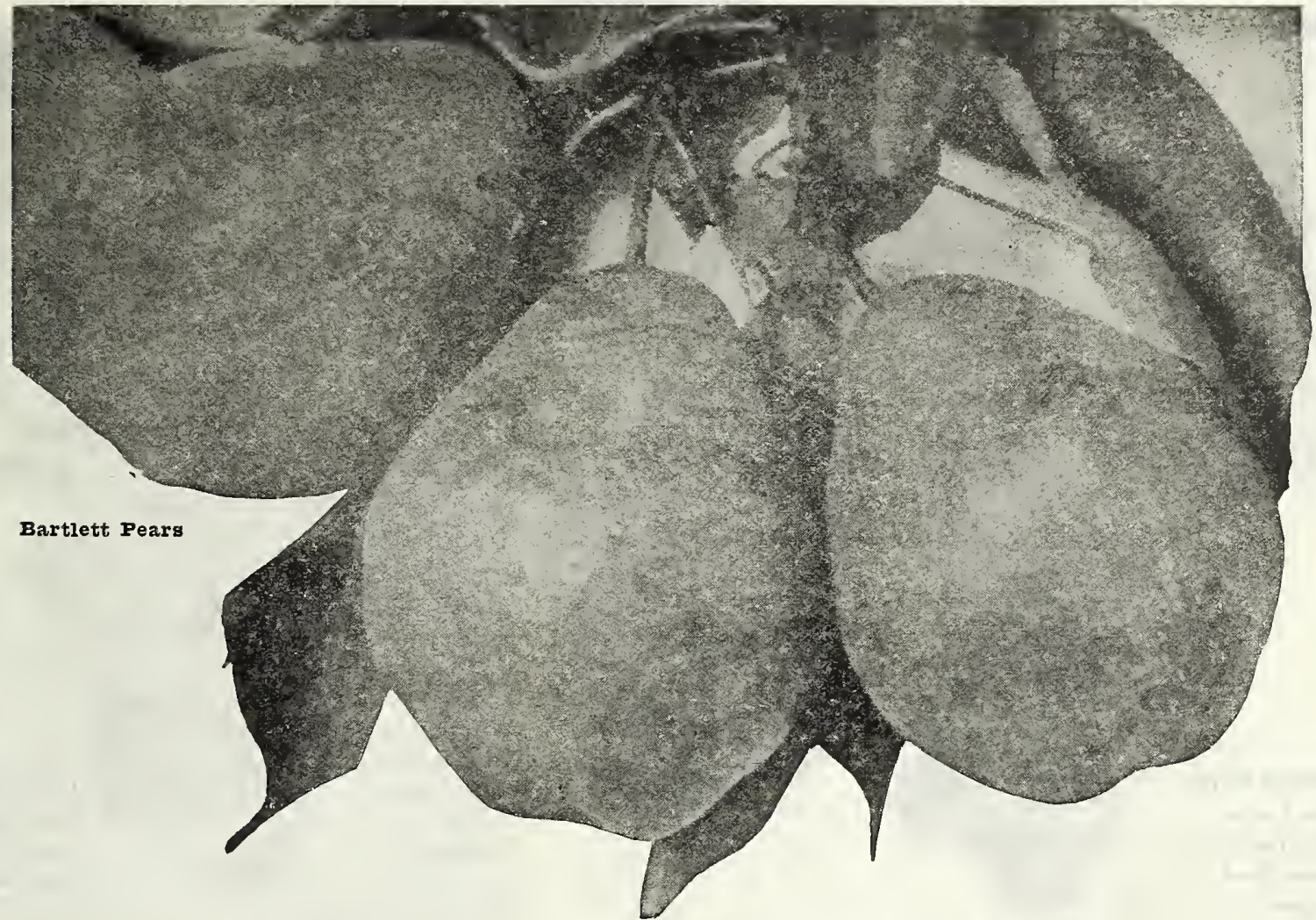

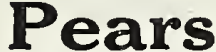

There is no section of this great Southwest that will not produce an abundance of this splendid fruit, hence they should be universally planted. The Kieffer is the most popular of all sorts and will grow everywhere. Plant irees 20 feet apart, about 110 trees to the acre. Head low on account of the sun scald. Pear trees are beautiful for the lawn, being the first to bloom in the spring, and are literally covered with perfumed flowers, besides giving an abundance of fruit.

Small size, prepaid, 75c each, $\$ 6.50$ dozen.

Medium size, prepald, $80 \mathrm{c}$ each, $\$ 8.00$ dozen

Iarge size, prepaid, $\$ 1.30$ each, $\$ 13.00$ dozen.

Kieffer The best variety for the Southwest. Almost entirely free from blight and is a strong, upThe most valuable sort for market and is especially valuable for cooking purposes. Large, yellow with rusty cheek. October.

Garber The Garber has the hardy constitution, rapid growth, the prolífic bearing qualitíes of Kíffer and Le Conte, and fills the gap between the two, ripening after the former and before the latter. In size and alypearance it resembles Kieffer, but is of superior flaver A splendid canning pear. Our trees are very healthy and prolific.

Duchess One of the best Pears for Texas. Fruit large Duchess and juicy, with a rich, excellent flavor. Somewhat knotty, uneven surface. September.

Wilder Medium size, greenish yellow, with brown cheek and numerous flecks. Flesh white, fine grained, melting, excellent July.

Bartlett Tree thrifty and upright. Fruit large and Le Conte Bell-shaped. Skin smooth and of rich, is excellent for cooking. Fruit good when ripened well in shade. July.

Seckel Tree a moderate grower and less subject to yellowish brown and red; rich, fine flavored. August.

Clapp's Favorite Resembles Bartlett, but is someBartlett and Flemish Beauty. Fruit large and of yellowish color marbled with red. One of the best summer pears. A ugust.

\section{Figs \\ Common Varieties}

Hardy in south Texas. In North Texas unprotected tops will sometímes winter kill, but when frozen tops are cut off new shoots will come and bear fruit late in suinmer of sanie season. Like rich garden soil. Plant 10 feet apart

Prices on all varieties of figs for popular transplanting size, $60 \mathrm{c}$ each, $\$ 6.00$ dozen, prepaid; large size, $\$ 1.00$ each, $\$ 10.00$ dozen, prepaid.

Brown Turkey Large, very sweet, hardy, reliable. Brunswick Very large, white. Productive and Celestial A small pale víolet fruit. Very sweet,

Ischia Medium size, greenish white when ripe Flesh A good table variety. Magnolia Fruit very large and of rich straw color tinues to put on new fruit untíl frost. Trees bear when quite young, Doubtless the most profitable variety grown

\section{Mulberries}

Price, medium size, prepaid, $75 \mathrm{c}$ each, $\$ 7.50$ dozen. Price, large size, prepaid, $\$ 1.25$ each, $\$ 12.00$ dozen.

Hicks Evergreen Fíne grower and profuse bearer, August.

Black English $\begin{aligned} & \text { Very prolific and earlíer than the } \\ & \text { Hicks, }\end{aligned}$

\section{Japan Persimmon}

Introduced from Japan. Leaves are broad and burnished. Trees vary from shrubby growth of 8 and 10 feet to a much larger size. Usually very prolific. Price, $\$ 1.25$ each. 


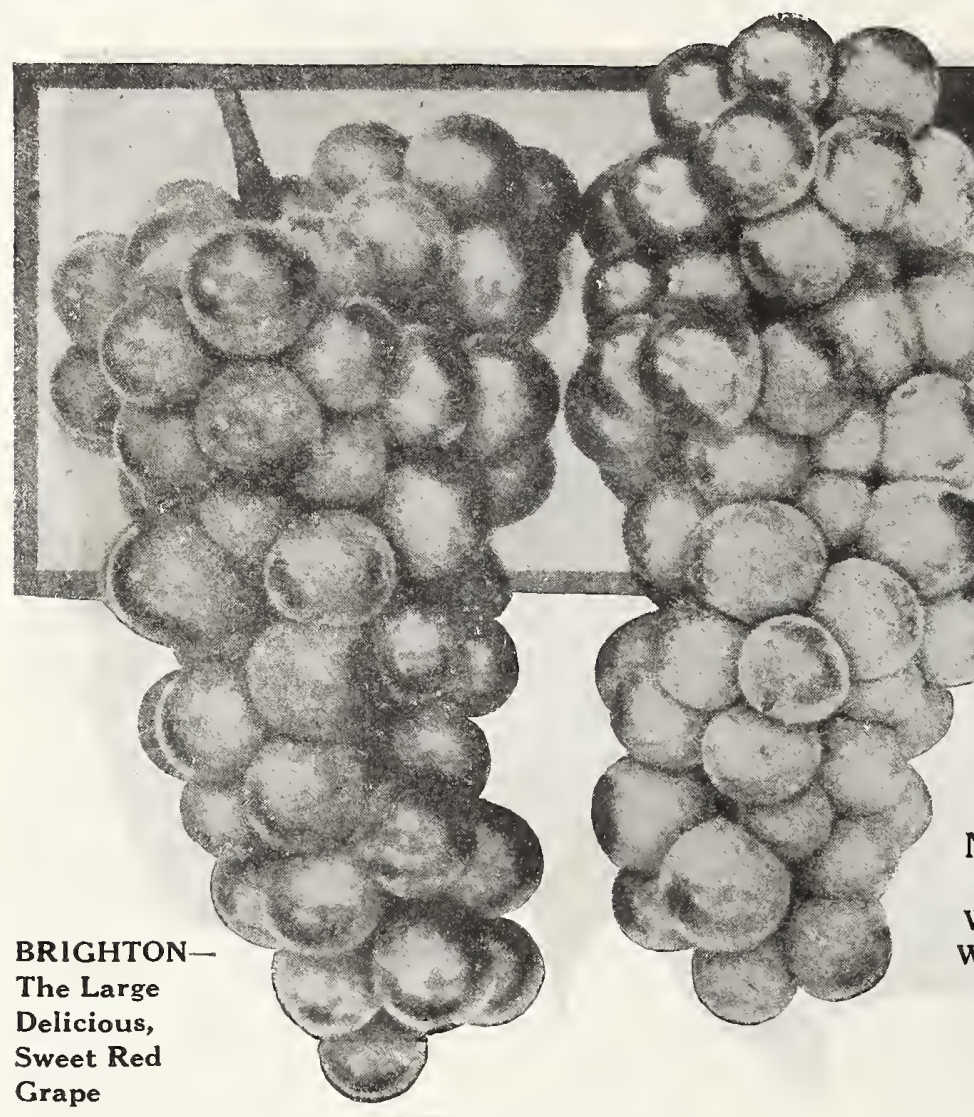

NIAGARA

When you

Want a Fine

White Grape,

Plant

Niagara

\section{Grapes}

Every home should have a planting of this luscious fruit. The best way is to plant them in rows 6 to 8 feet apart cach way and train on stakes or trellis, though they can be trained on fences or porch, furnishing not only shade but abundance of fruit. Prune severely for a year or two allowing the vines to forn four or five stems; after this prune to suit the individual taste. Fertilize the soil heavily and plant a little deeper than when in nursery.

Don't fail to plant grapes and you will not regret doing so.

Prices, except where otherwise noted, $50 \mathrm{c}$ each, three for $\$ 1.48, \$ 5.50$ per dozen. Write for our special prices on 50 to 100 lots.

Niagara Bunch medium to large, comnact, sometimes shouldered. Berries arse, skin thin but tough. pale green at first, changing to pale yellow when fully ripe, with a thin whitish bloom. Flesh slightly pulpy, tender and sweet. It has a musky odor which disappears when fully ripe, Ripens with

Wyoming Red A very early red grape. Bunch small, compact and hand. some Berry medium, slin bright red, thick, firm; fru: sweet, forr, but a tastes. Very hardy and healthy. Foliase small, thick, leathery. June.

Brighton large compact bunches, rich wine color, tender and almost seedabled to withstand the heat of and rich flavor. Having thick foliage, it is enyard or, garden. June.

Concord The old standby A large purple grape, moderately sweet anü Moore's Early Bunch medium, berry large, round with heavy bloom. Vine earliness makes it desirable. Perries black. Two weeks earlier than Concord. June.

Delaware Bunches small, compact, shouldered "Beries rather smali, round, Flavor sweet, spicy, delicious. June. Flesh very juicy and without hard pulp. Ives Seedling Frealthy and a strong grower. Bush and fruit medium to Flesh sweet and juicy, but foxy and puffy. Dark Catawba Well known as the great wine grape. Bunches and berries large, rich, musky tlavor. August

Carmen Medium, round, black, fine quality, vigorous and productive. August. Scuppernong Berries very large. Bronze colored. Fine wine grape, \$1.25

\section{Supreme Big "6" Grape Collection}

Our Selection of Six Choice Varieties of TwoYear Old Roots

Sent Anywhere Postpaid for

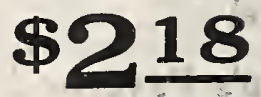




\section{Blackberries and Dewberries}

These fruits are easily grown and are very valuable. They bear the second year after planting, and yield a fruit that is profitable for both home and market. The fruit is borne on the previous year's growth and after frujting the canes die, then all dead wood

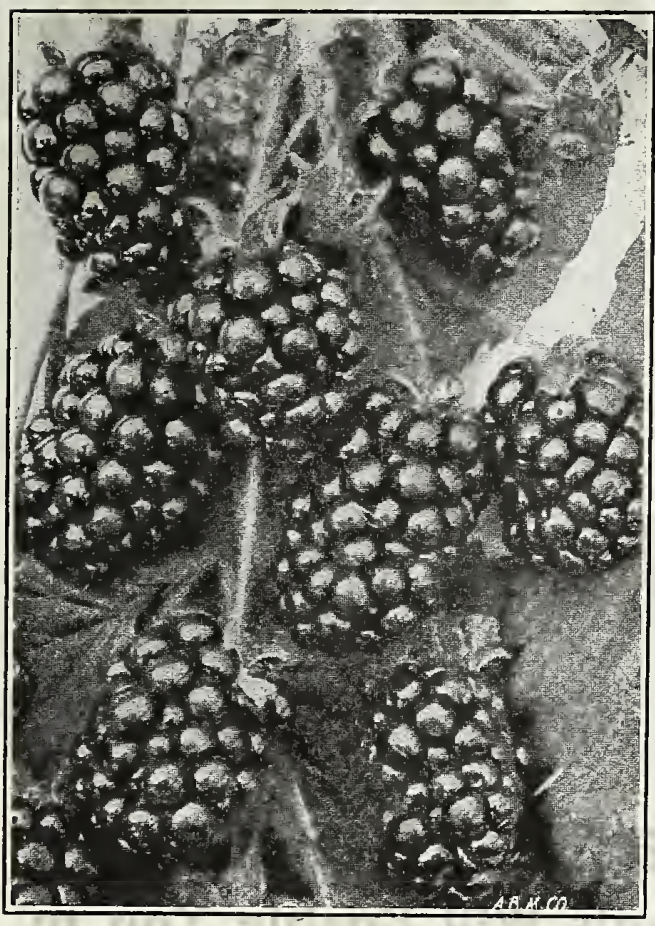

Dallas Blackberry removed. Price, pre: p a i d, 25 plants $\$ 1.75$, 50 pla nts $\$ 3.00,100$ p 1 a nts $\$ 5.00$.

\section{Rogers} Dewberry

Large, black, delicious. The e a liest variety,
ripening in April.

\section{Austin} Dewberry

Fruit very large and fine flavored. Produces a full crop each year.

\section{Dallas Blackberry}

Very visorous, drooping, thorny. Robinson Blackberry Mid-season.

Large, delicious, very valuable.

McDonald A cross between the Dewberry and Blackberry. dewberry. This variety needs a perfect flowering sort nearby a pollinate to make it productive. The berry is large and of excellent quality. Earliest of all.

\section{Make Your Own Blackberry Jam}

\section{Sage for Sausage}

\section{Grow Your Own Sage-Have It Ready at Hog Killing Time}
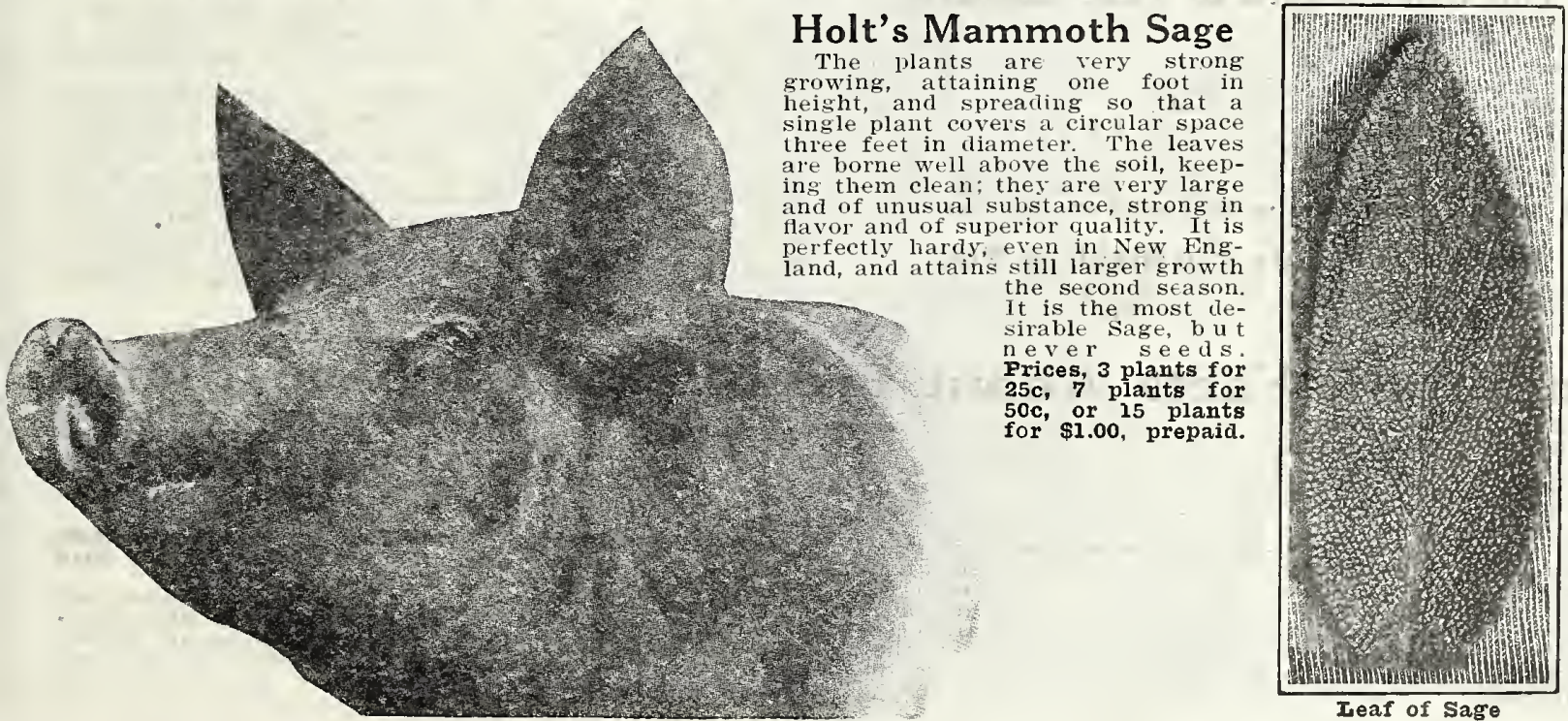


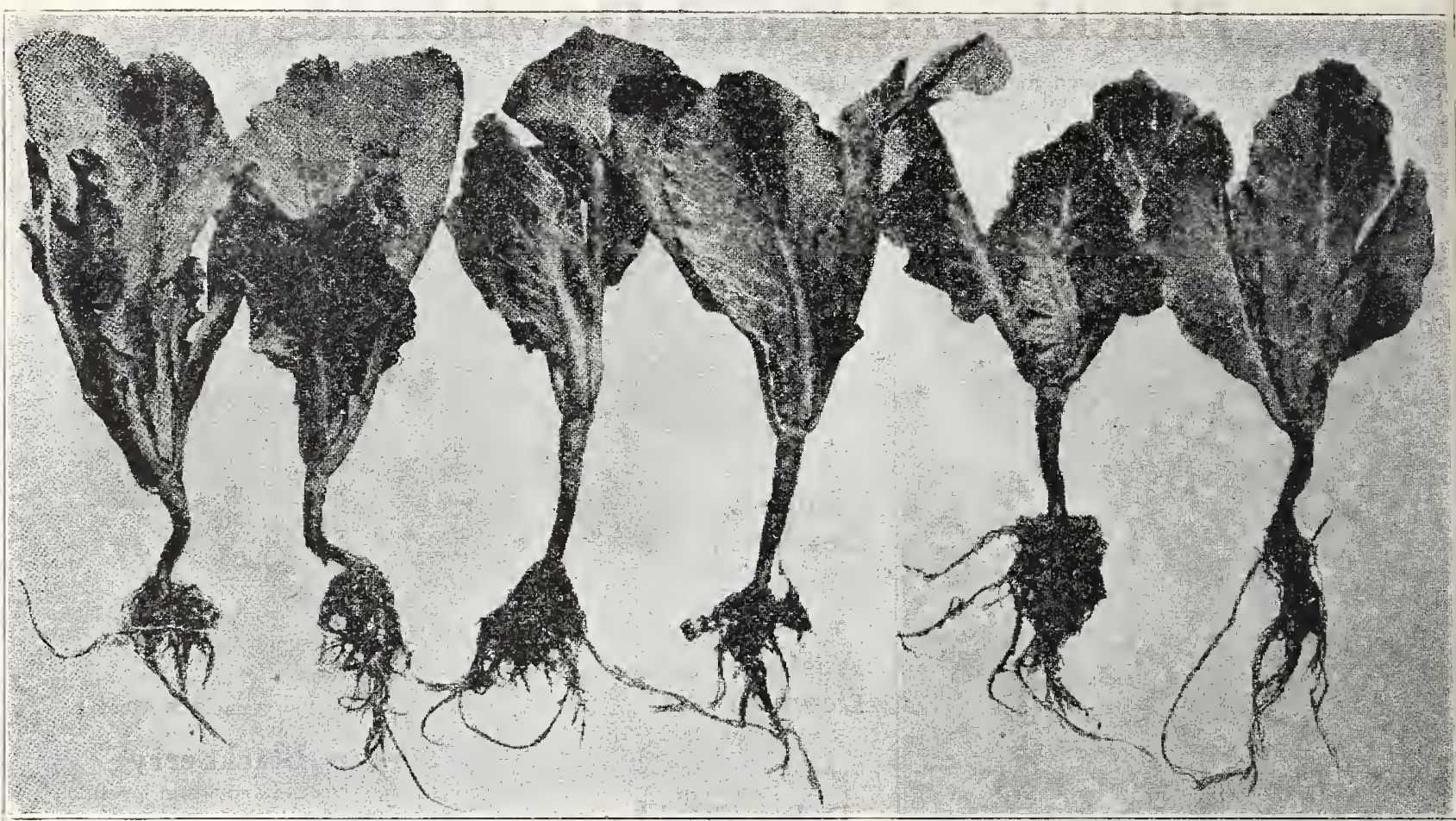

\section{Frost-Proof Cabbage Plants}

\section{Planting Our Frost-Proof Cabbage Plants Will Enable You to Market Cabbage Two to Four Weeks Earlier Than When Home Grown Plants Are Used}

For several years we have been growing cabbage plants by the several million. Each year the same customers have been coming back for plants in larger quantities and new customers have been buying heavily. As a result this part of our business has developed into enormous proportions.

\section{You Can't Afford to Take Chances}

The cabbage plants we offer are grown from the best seed obtainable. When you order plants from us you do not get the left-overs from a market-gardener's crop. Our plants are of the best quality and are shipped to you when at the proper age for transplanting. Many firms offer plants which they secure at a very low price from gardeners who have many plants (culls) left over after planting out all they intend to grow for market. We can supply the following varieties this season: Farly Jersey Wakefield, Flat Dutch, Charleston Wakefield and Succession.

\section{Prices of Plants Postpaid to You}

In lots of $100,200,300$ or 400 plants at $60 \mathrm{c}$ per 100 plants; 500 plants for $\$ 2.00 ; 1,000$ or more at $\$ 3.75$ per 1,000 plants.
Orders are filled by the 100 not 250 or 350 . These prices are for even quantities of our variety to package; if you ordered 200 of one variety and 300 of another variety, you would pay at the 100 rate.

\section{Cabbage Plants by Express Collect}

Many of our customers, and especially those buying in extra large quantities, usually prefer express shipment, as in large quantities the transportation is somewhat less than by parcel post.

For these we make the following prices, you paying express charges on arrival of the plants at your office: In lots of 1,000 to 4,000 plants at $\$ 2.75$ per 1,$000 ; 5,000$ or more at \$2.25 per 1,000. Plants packed for express shipment, 1,000 or 2,000 piants of a variety to a package weigh about 25 pounds per thousand plants, packed for shipment. For the past two years the express seryice has been congested, and the deliveries slow and unsatisfactory. We are not responsible for delays caused by transportation companies. We, therefore, advise Parcel Post shipment.

\section{Important Facts About Frost-Proof Cabbage Plants}

The plants make a slow but steady growth until at eight to ten weeks of age they are very tough and hardy, the buds are purple and the outer leaves a reddish-brown. When in this condition they can be shipped to territory farther north and be planted in the open ground a month to six weeks sooner than the home-grown hotbed or cold frame plants. These frost-proof cabbage plants will stand a temperature of 15 degrees above zero without injury. The land freezing, or the plants being covered with ice, sleet, or snow after they are planted will not injure them. The top of the plant does not grow until regular spring weather opens up, but the roots grow from the time they are planted, and just as soon as Spring weather starts, the established root growth assimilates the fertilizer in the soil, the plants grow very fast, maturing headed cabbage two to four weeks sooner than you can mature them from hotbed and cola frame plants. You know what the difference in profit will be if your crop is matured and marketed before the general crop from home-grown plants is ready.

To get the advantage of these frost-proof cabbage plants they mugt be planted a month or six weeks earlier than you would plant home-grown plants.

ou woxld plast hilted and The plants when received wil which will be disappointing to persons who have never used these plants before. Regardless of appearance, they will produce the crop results. 


\section{ASPARAGUS ROOTS}

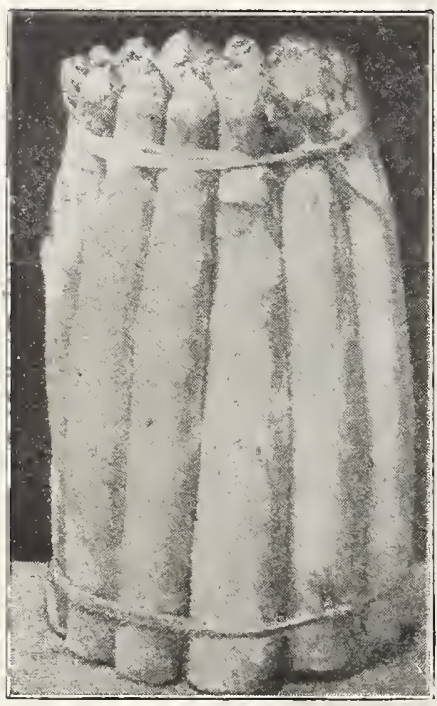

Asparagus

\section{PEPPER PLANTS}

Neapolitan Large Farly Sweet Pepper, Improved Bull Nose, Chinese Giant, Ruby King. Chili, Tabasco. Ready from January 15 on. Price, dozen $20 \mathrm{c}, 100$ for $75 \mathrm{c}, 500$ for $\$ 3.00,1,000$ for $\$ 5.00$, prepaid.

Flower and Vine Seed African Daisy ...........

Ageratum

Amaranthus

Aquilegiam $\ldots \ldots \ldots \ldots, 17$

Aquilegia $\ldots \ldots \ldots \ldots \ldots, 8$

Baby's Breati .......... 9

Salloon Vine ......... 19

Balsam Apple ......... 19

Bermuda Grass ........ 17

Calliopsis

Campanula

Canary Bird Flowe...... 19

Candytuft

Canterbury Bells

Cardinal Climber.

Carnations

Caster Oil Bean.

Celosia

Chinese woolfower

Chrysanthenums

Clematis

Coleus

Columbine

Cornflower

Cosmos

Daisies

Dianthus

Digitalis

Dimorphotheca

Feverfew

Floss Flower

Four O'Clock

Foxglove

Geranium

Grourds seed

Heliotrope

Hollyhocks

Jack Bean

Kochia

Lady Slipper

Lantana

Planted in late fall
and early roots all winter malie yield first season when our large two-year-oid Asparagus is a most desirable adjunct to any home place, and repre. sents a big saving. pensive at market. If grown to any extent, it beds should be narrow. so as to permit of cutting to the center. Set plants a bou t a fout below the surface. Cover the transplanted beds manure. Salt is an excellent fert i l i zee r for

\section{Conover's Colossal}

Price, 50 roots for $\$ 1.25$. 100 for $\$ 2.25,1,000$ for $\$ 16.50$, prepaid.

Columbian Mammoth Price, 50 for $\$ 1.50,100$
for $\$ 2.50,1,000$ for $\$ 18.00$. 
MA

-

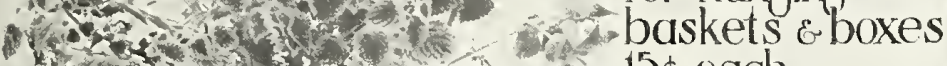

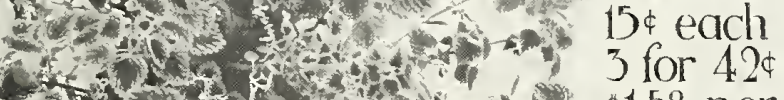

$4+30,31.58$ per doz.

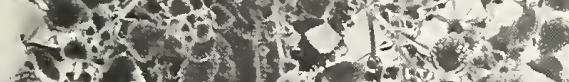

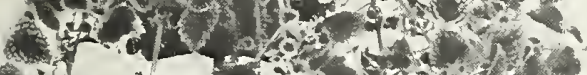

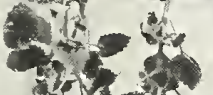

a
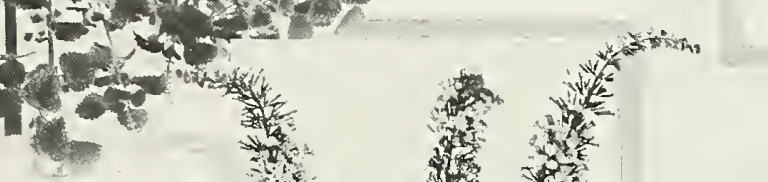

ButTERFLY Bush -

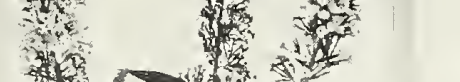

(BUDDLELA)

Small Plants $35 \$$ each 3 for $\$ 1.00$

Field grown Plants 75\& each

Bermuda Onion Plants

100 for $50^{\ddagger}$

500 for $\$ 1.50$

1000 for $\$ 2.60$

All prepaid
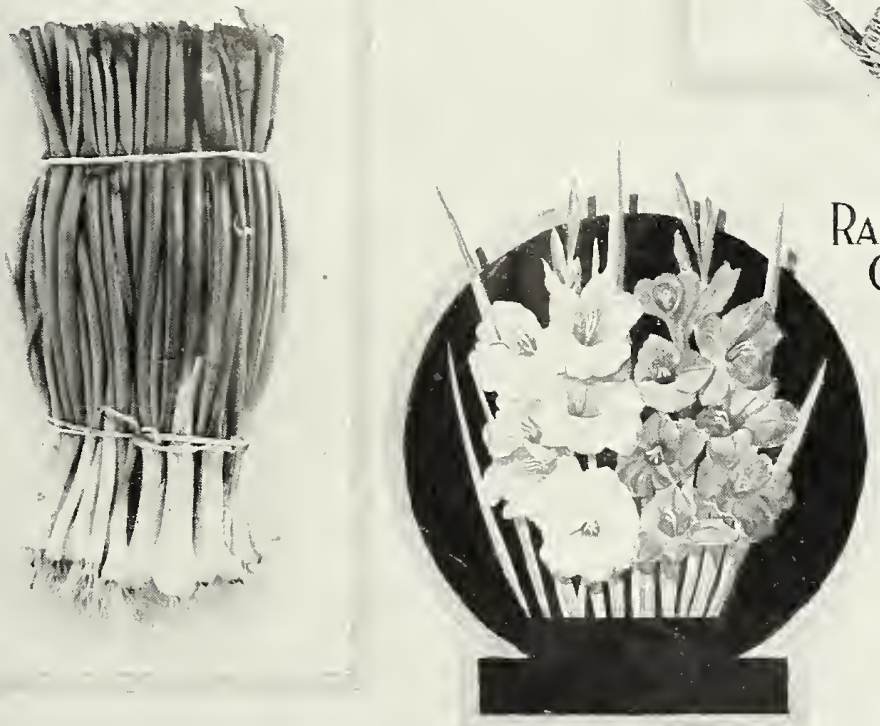

PoM POM

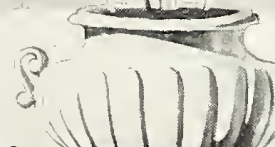

DeCorative

PALMS.

CHRYSANTHEMUM

COLLECTION

$\$ 1.18$ Postpaid 10 Plants

Best Varieties,All Colors
Small Plants $48+$ each Large Plants 984 each 
